UNIVERSIDADE DE SÃO PAULO

FACULDADE DE EDUCAÇÃO

PAULO HENRIQUE NICO MONTEIRO

\title{
A saúde nos livros didáticos no Brasil: concepções e tendências nos anos iniciais do Ensino Fundamental
}

São Paulo

2012 



\section{PAULO HENRIQUE NICO MONTEIRO}

\section{A saúde nos livros didáticos no Brasil: concepções e tendências nos anos iniciais do Ensino Fundamental}

Tese apresentada à Faculdade de Educação da Universidade de São Paulo para obtenção do título de Doutor em Educação.

Área de Concentração: Ensino de Ciências e Matemática

Orientador: Prof. Dr. Nelio Marco Vincenzo Bizzo

São Paulo 
AUTORIZO A REPRODUÇÃO E DIVULGAÇÃO TOTAL OU PARCIAL DESTE TRABALHO, POR QUALQUER MEIO CONVENCIONAL OU ELETRÔNICO, PARA FINS DE ESTUDO E PESQUISA, DESDE QUE CITADA A FONTE.

Catalogação na Publicação

Serviço de Biblioteca e Documentação

Faculdade de Educação da Universidade de São Paulo

$371.34 \quad$ Monteiro, Paulo Henrique Nico

M775s A saúde nos livros didáticos no Brasil: concepções e tendências nos anos iniciais do Ensino Fundamental / Paulo Henrique Nico Monteiro; orientação Nelio Marco Vincenzo Bizzo. São Paulo: s.n., 2012.

210 p.; anexos

Tese (Doutorado - Programa de Pós-Graduação em Educação. Área de Concentração: Ensino de Ciências e Matemática) - - Faculdade de Educação da Universidade de São Paulo.

1. Saúde 2. Livro didático 3. Educação em saúde 4. Ensino fundamental I. Bizzo, Nelio Marco Vincenzo, orient. 


\section{FOLHA DE APROVAÇÃO}

Nome: MONTEIRO, Paulo Henrique Nico.

Título: A saúde nos livros didáticos no Brasil: concepções e tendências nos anos iniciais do Ensino Fundamental.

Tese apresentada à Faculdade de Educação da Universidade de São Paulo para obtenção do título de Doutor.

Área de Concentração: Ensino de Ciências e Matemática

Aprovado em:

Banca Examinadora

Prof. Dr.

Instituição: Assinatura:

Prof. Dr.

Instituição: Assinatura:

Prof. Dr.

Instituição: Assinatura:

Prof. Dr.

Instituição: Assinatura:

Prof. Dr.

Instituição: Assinatura: 

Á Vanessa, com quem venho, ao longo desses anos, aprendendo a partilhar e compartilhar sonhos e ideais.

Aos meus queridos Cecília e Mateus, que cresçam em um mundo onde a Educação e a Saúde não sejam privilégios. 



\section{AGRADECIMENTOS}

Ao meu orientador Prof. Dr. Nelio Bizzo, que desde o princípio acolheu meu trabalho de maneira respeitosa e generosa. Obrigado Nelio, por ter me propiciado muitos e importantes momentos de aprendizagem e crescimento profissional no decorrer deste percurso. Obrigado também por ter podido compartilhar de sua amizade e convívio.

À querida Vanessa, por ter me apoiado nessa aventura acadêmica (desde o mestrado) e por arcar com os momentos em que estive ausente. Obrigado pela paciência, amor, dedicação e esforço em cuidar das crianças, sem os quais essa trajetória não teria sido possível. Obrigado também pela leitura atenta e cuidadosa do texto e pelas observações sempre pertinentes.

À Biba, Cecília, Lígia e Renato, amigos do Instituto de Saúde, pelo apoio e pela compreensão nos momentos em que me dediquei a esse trabalho, com a certeza de que nunca ouviram falar tanto de livros didáticos.

Aos colegas do GONB, os atuais e aqueles com que pude conviver ao longo dessa trajetória. Obrigado pelas importantes contribuições dadas nos momentos de discussão em grupo, que certamente qualificaram e enriqueceram o trabalho aqui apresentado.

À professora Ausonia Donato que, mesmo indiretamente, vem me apoiando e me ensinando muito ao longo da minha vida, principalmente a sempre me alertar sobre o "em nome de que" da prática pedagógica. Obrigado Ausonia pela amizade e pela orientação.

Ao amigo Ricardo Barreto, com quem há muito tempo compartilho ideias e projetos. Obrigado pelo apoio e incentivo no início dessa jornada.

Aos professores Carlos Botazzo e Isabel Martins pelas importantes contribuições dadas no exame de qualificação.

Ao professor Nelson Studart pela possibilidade de acessar o acervo de livros didáticos aqui analisados. 

O ensinar e o aprender devem estar associados aos objetivos da educação do estudante: compreender por que as coisas são como são e como vieram a se tornar assim; tornar o familiar estranho e o estranho familiar; correr riscos e lutar contra as relações de poder vigentes, a partir de uma cultura moral que valoriza a vida; assim como visualizar um mundo que 'ainda' não está em ordem, para ampliar as possibilidades de melhoria das condições de vida.

Henry Giroux e Roger Simon (2002). 



\section{RESUMO}

MONTEIRO, P.H.N. A saúde nos livros didáticos no Brasil: concepções e tendências nos anos iniciais do Ensino Fundamental. 2012. Tese (doutorado em educação) Faculdade de Educação, Universidade de São Paulo, São Paulo, 2012. 210 f.

Os temas relacionados à saúde humana são tradicionalmente desenvolvidos desde os anos iniciais da escolarização formal, sendo obrigatórios na Educação Básica no Brasil desde 1971. Por se tratar de um termo polissêmico, a saúde, assim como os fatores que a influenciam e determinam podem ser entendidos de diversas formas que acabam por conformar distintas abordagens para o ensino do tema em sala de aula. Dentre os materiais de apoio ao professor, o livro didático, pelo papel que desempenha no cotidiano escolar, pode ser considerado como importante, senão o principal, instrumento de organização curricular, inclusive no que tange à abordagem relacionada à saúde. Portanto, o modo como a saúde está presente nesse material influencia diretamente o entendimento que alunos e professores têm sobre o tema, assim como os objetivos educacionais a ele relacionados. $\mathrm{O}$ presente trabalho, embasado nos referenciais teóricos dos campos da Saúde Coletiva e da Epidemiologia Social, tem como objetivo investigar como e a partir de que concepções os conteúdos relacionados à saúde humana são abordados nos livros didáticos de Ciências para os anos iniciais do Ensino Fundamental no Brasil e qual a importância atribuída aos diversos fatores que influenciam e determinam o processo saúde-doença. Foram analisadas as onze coleções aprovadas pelo Programa Nacional do Livro Didático em 2010, a partir do mapeamento dos temas relacionados à saúde, das concepções de saúde presentes, do papel atribuído aos seus determinantes e dos objetivos educacionais relacionados ao tema. Apesar de importantes diferenças encontradas entre eles, os livros tendem a abordar o tema a partir de uma perspectiva que enfatiza e reduz a saúde a seus aspectos biológicos, atribui pouca relevância aos seus determinantes sociais e tem como foco o indivíduo e seu conjunto de comportamentos e hábitos, sendo a modificação ou adequação destes o principal objetivo a ser alcançado. Sugere-se que esse material incorpore os avanços conceituais da área da saúde, a fim de tratar o tema a partir de uma moldura mais ampla que leve em conta os aspectos de distintas naturezas que interferem na situação de saúde dos indivíduos, grupos e população, com vistas a tornar mais significativas e contextualizadas as discussões sobre a saúde em sala de aula.

Palavras-chave: saúde, livro didático, concepções de saúde, educação em saúde, Ensino Fundamental. 


\begin{abstract}
The issues related to human health are traditionally developed since the early years of formal schooling, being mandatory in Basic Education in Brazil since 1971. Health, due to is a polysemic term, as well as the factors that influence and determine health situation can be understood in different ways, that ultimately conform distinct approaches to the teaching of this subject inside and outside the classroom. Among the various materials in support of the teacher, the textbook, because of the role it plays in everyday school life, can be considered as important, if not the main instrument of curriculum organization, including those related to health issues. Indeed, how health is present in this material directly influences the understanding that students and teachers have on the subject, as well as the educational objectives related to it. This study, based on the theoretical fields of Collective Health and Social Epidemiology, aims to investigate how and from what conceptions content related to human health are discussed in Science textbooks for the early years of Elementary School (Ensino Fundamental) in Brazil and what is the role attributed to several factors that influence and determine the health-disease process. We analyzed the eleven collections approved by the National Textbook Program in 2010 (PNLD 2010) from the mapping of health issues, the understandings and conceptions on health present in these materials, the role assigned to its determinants and the educational objectives related to the topic. In spite of significant differences between them, the textbooks examined tend to approach the issue from a perspective that emphasizes and reduces health discussions to its biological aspects; attaches little importance to the social determinants of health and focuses on the individual and whole behaviors and habits pointed the modification or adaptation of these as the main objective to be achieved. It is suggested that this material addresses the conceptual advances in the health area, in order to address the issue from a broader framework that takes into account the different aspects that affect the health status of individuals and population groups, in order to make more meaningful and contextualized the discussions on health in the classroom.
\end{abstract}

Key-words: health, textbooks, health conceptions, health education, Elementary School. 


\section{SUMÁRIO}

1. APRESENTAÇÃO DO TRABALHO E DELIMITAÇÃO DO PROBLEMA DA PESQUISA .................................................................. 17

1.1. Motivações iniciais e interesses ................................................................ 17

1.2. O Objeto da Pesquisa: A Saúde nos Livros Didáticos ............................. 19

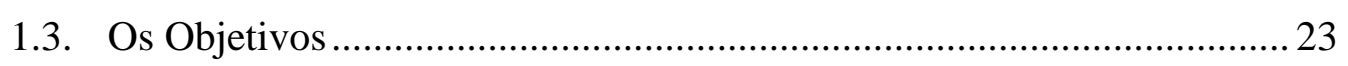

1.3.1. Objetivo Geral ....................................................................... 23

1.3.2. Objetivos específicos ................................................................. 24

1.4. A estrutura do trabalho ....................................................................... 24

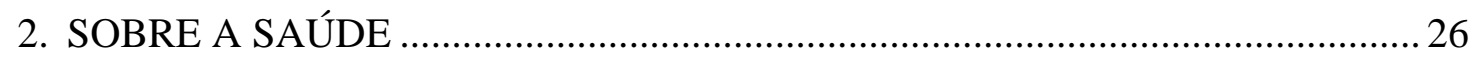

2.1. A saúde e o processo saúde-doença ......................................................2 26

2.2. O processo saúde-doença e suas teorias explicativas ................................. 31

2.2.1. A Vertente Ontológica: a doença como um "mal", a perspectiva mágico-religiosa e as teorias miasmáticas .............. 32

2.2.2. A vertente dinâmica: a saúde como equilíbrio e a tradição hipocrática ............................................................................. 36

2.2.3. O Século XIX: o estudo científico da sociedade, as bases da medicina social e a relação saúde e condições de vida.

2.2.4. A descoberta do caráter patogênico dos micróbios, o Relatório Flexner e a constituição do modelo biomédico

2.2.5. As insuficiências do modelo biomédico e a retomada da perspectiva social. .................................................................... 51

2.2.6. A Epidemiologia Social, a Determinação Social e seus modelos explicativos.

2.2.7. A Promoção da Saúde: retomada de uma ideia, histórico de construção do conceito e sua crítica.

2.2.8. Promoção da Saúde e Prevenção de Doenças: diferenças.

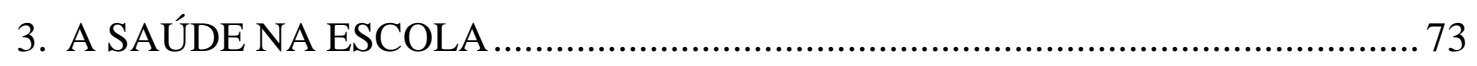

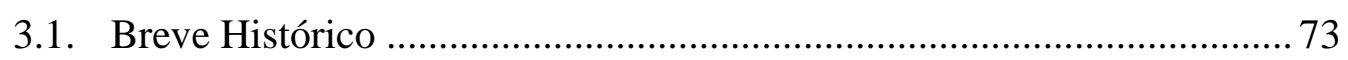

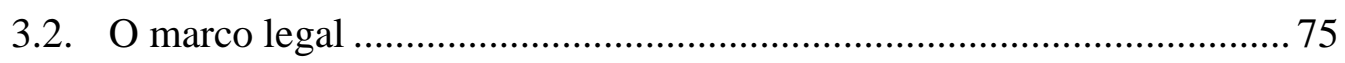

3.3. A saúde nos Parâmetros Curriculares Nacionais....................................... 80

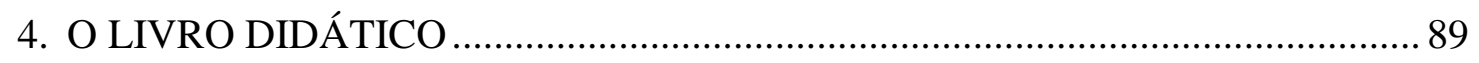

4.1. O livro didático como objeto de estudo.................................................... 89 
4.2. O Livro Didático no mercado editorial: sua natureza e seu processo de produção

4.3. O Livro Didático e seu papel em sala de aula 94

4.4. Os programas oficiais do Livro Didático no Brasil. 97

5. O PERCURSO METODOLÓGICO: O CAMINHO DA PESQUISA 103

5.1. O universo da pesquisa: os livros didáticos do PNLD 2010 104

5.2. As Categorias Analíticas 105

5.3. Coleta, tratamento dos dados e critérios de seleção das unidades 106

5.4. Os planos de análise 108

6. A SAÚDE NOS LIVROS DIDÁTICOS PARA OS ANOS INICIAIS DO ENSINO FUNDAMENTAL

6.1. Análise por Coleção 110

6.2. As coleções. 111

6.3. Análise Geral 143

6.3.1. As unidades de análise e os anos de escolaridade 143

6.3.2. Os Temas: o comum e o episódico 146

6.3.3. As Concepções de Saúde: distanciamentos entre o discurso e a prática

6.3.4. Os determinantes do processo saúde-doença. Hábitos e estilo de vida: o indivíduo responsável por sua saúde 165

6.3.5. Os objetivos: risco e prevenção 178

7. CONSIDERAÇÕES FINAIS E IMPLICAÇÕES PARA O ENSINO DO TEMA DA SAÚDE

8. REFERÊNCIAS BIBLIOGRÁFICAS 198

9. ANEXOS 209

ANEXO A: As coleções analisadas

ANEXO B: modelo da matriz analítica 


\section{APRESENTAÇÃO DO TRABALHO E DELIMITAÇÃO DO PROBLEMA DA PESQUISA}

\subsection{Motivações iniciais e interesses}

As indagações e incômodos iniciais que motivaram a proposição do presente trabalho dizem respeito à minha trajetória profissional que, ao longo dos anos, me levou do campo da educação escolar, onde atuei como professor do Ensino Fundamental e Médio, para o campo da saúde, onde trabalho atualmente como pesquisador científico do Instituto de Saúde da Secretaria de Estado da Saúde de São Paulo, onde atuo no campo da educação e saúde, que se caracteriza por estar na interface entre os campos teóricos da Educação e da Saúde.

A partir dessa trajetória, pude perceber que a compreensão sobre o tema da saúde e sobre os fatores que influenciam e determinam a situação de saúde das pessoas e dos grupos populacionais é muito heterogênea na população em geral e, inclusive, nos profissionais dessas duas áreas e exprimem, em última análise, diferentes concepções de saúde. Ou seja, existem compreensões muito distintas sobre como se dá o processo saúde-doença, seus modelos explicativos, sobre os fatores que condicionam e determinam a situação de saúde dos indivíduos e da população, sobre as causas do adoecimento e da cura etc.

Essa heterogeneidade influencia de maneira decisiva as propostas de atividades educativas voltadas à saúde (ou de educação em saúde) que são formuladas e implementadas junto à população, dentro e fora do sistema de saúde, incluindo o espaço da escolarização formal, a escola.

Além disso, é bastante comum o discurso de que a escola é um espaço privilegiado para o desenvolvimento de aprendizagens voltadas à saúde e que a educação tem papel fundamental na melhoria da qualidade de vida das pessoas, sendo a saúde considerada como aspecto fundamental dessa melhoria.

Dada essa heterogeneidade de compreensões, a pergunta inicial a ser colocada diz respeito a como se constroem essas concepções ou, em outras palavras, onde e de que maneira os indivíduos "aprendem" o que é saúde? Mais especificamente, pode-se perguntar: qual é o papel que a escola desempenha na construção de conceitos e ideias relativas ao tema e sobre o papel e importância dos diversos fatores (intrínsecos ou extrínsecos ao indivíduo, naturais ou historicamente constituídos, de caráter individual ou coletivo etc.) na conformação da situação de saúde dos indivíduos, grupos e população? 
No âmbito da escolarização formal, cabe tradicionalmente às disciplinas e aos professores de Ciências (no Ensino Fundamental), Biologia (no Ensino Médio) e Educação Física o desenvolvimento das propostas e dos conteúdos relacionados à saúde. Tais professores são vistos, inclusive por eles próprios, como "os agentes de saúde dentro da escola", que são os responsáveis pelo desenvolvimento de atitudes favoráveis à saúde, pela mudança e aquisição de "hábitos saudáveis" por parte dos alunos, assim como pelas orientações acerca de medidas e atitudes de prevenção relacionadas a doenças ou agravos específicos.

Nesse sentido, cabendo a esses professores desenvolver tais conteúdos, suas propostas dependem de sua formação em relação ao tema, do material de apoio que dispõem e, fundamentalmente, do entendimento que têm do próprio conceito de saúde e pelo papel desempenhado pelos diversos fatores que influenciam o estado de saúde das pessoas. Esse entendimento influencia de maneira decisiva a definição dos seus objetivos educacionais, do conteúdo a ser desenvolvido e seu encadeamento lógico, assim como a escolha dos aspectos que serão valorizados e enfatizados quando do desenvolvimento da temática em sala de aula.

Quanto ao material de apoio, o livro didático (LD) é uma das principais referências para a prática docente no Brasil. Sabidamente, o livro didático cumpre um papel importante na sala de aula, atuando como norteador do planejamento pedagógico do professor e consequentemente do processo ensino-aprendizagem. Em outras palavras, o LD tem papel fundamental na organização e desenvolvimento curricular.

O próprio Ministério da Educação (MEC) reconhece sua importância, na medida em que entre seus principais programas estão aqueles ligados à compra e fornecimento de livros didáticos para as escolas públicas. Nesse contexto, é possível dizer que o desenvolvimento dos temas relacionados à saúde humana em sala de aula é profundamente influenciado pelo livro didático, na medida em que este muitas vezes é também um importante material de formação para os professores, especialmente a partir de textos de apoio que, muito comumente, fazem parte dos "manuais para o professor" que acompanham os livros.

Tendo a oportunidade de participar do Grupo de pesquisa em "Ensino de Ciências"1 pude aprofundar minhas reflexões e indagações acerca do ensino de ciências e do papel que o desenvolvimento do pensamento científico pode desempenhar no desenvolvimento geral do

\footnotetext{
${ }^{1}$ Grupo de pesquisa vinculado ao Departamento de Metodologia e Educação Comparada da Faculdade de Educação da Universidade de São Paulo.
} 
aluno, com especial atenção às séries iniciais do Ensino Fundamental. Assim, entendo que é possível e desejável que as propostas para essas séries sejam capazes de proporcionar aos alunos condições para a compreensão da realidade em seus diversos aspectos e em diversos níveis de complexidade, com o intuito de desenvolver aprendizagens voltadas a um posicionamento crítico frente aos contextos em que vivem, incluindo os aspectos concernentes à saúde.

Sendo a saúde um processo multideterminado e influenciado por fatores de naturezas distintas, esse posicionamento crítico frente à realidade poderá, em última análise, criar condições para que esses alunos, suas famílias e comunidades possam enfrentar as condições desfavoráveis à saúde, no intuito de transformá-las ou minimizá-las, assim como potencializar as condições favoráveis presentes nesses contextos, com o objetivo de melhorar sua condição de vida e saúde.

\subsection{O Objeto da Pesquisa: A saúde nos livros didáticos}

A Constituição Federal do Brasil define, no seu artigo 196, a "saúde como um direito" que deve ser garantido "mediante políticas sociais e econômicas que visem à redução do risco de doença e de outros agravos e ao acesso universal e igualitário às ações e serviços para sua promoção, proteção e recuperação." (BRASIL, 1988).

A partir dessa perspectiva, a saúde deve ser vista como objeto de diversas políticas públicas, inclusive ligadas ao setor da educação, na medida em que a escola pode ser considerada um lugar privilegiado (não sendo o único) para o desenvolvimento de aprendizagens e discussão de conteúdos com vistas à melhoria da situação de saúde dos indivíduos e da população.

Mesmo sendo tradicionalmente objeto de estudo dos alunos, é a partir da promulgação da lei 5.692/71 em 1971 que o desenvolvimento de conteúdos relacionados à saúde humana passou a ser obrigatório na Educação Básica brasileira. Em seu artigo $7^{\circ}$, a referida lei define que "será obrigatória a inclusão de Educação Moral e Cívica, Educação Física, Educação Artística e Programas de Saúde nos currículos plenos dos estabelecimentos de $1^{\circ}$ e $2^{\circ}$ graus" (BRASIL, 1971), tendo como objetivo estimular o conhecimento e a prática da saúde e da higiene.

Mais recentemente, o ensino da temática passou a ser incorporado às Diretrizes Curriculares Nacionais para o Ensino Fundamental, que apontam a saúde como um dos 
componentes da Base Comum Nacional $(\mathrm{BCN})$ "que deve integrar-se em torno do paradigma curricular" em todas as escolas no Brasil, a fim de "legitimar e qualificar a ação pedagógica na diversidade nacional.” (BRASIL, 1998a, p.13). Esses conteúdos comumente fazem parte das propostas curriculares das disciplinas de Ciências e Educação Física, no Ensino Fundamental, e Biologia no Ensino Médio, assumindo, em muitos momentos, grande parte da carga horária dessas disciplinas.

Ou seja, o tema da saúde faz parte do currículo dessas e de outras disciplinas que buscam, por meio do desenvolvimento de diversos conteúdos e discussões em sala de aula, propiciar condições para o desenvolvimento de um conjunto de aprendizagens por parte dos alunos que têm como fim melhorar suas condições de saúde, ou no mínimo, não piorá-las.

Sendo um termo polissêmico, cuja definição está vinculada ao entendimento de que papel a Educação deve ter na sociedade e de como se dá o processo ensino-aprendizagem (SILVA, 2003), o termo currículo vem sendo entendido e definido ao longo do tempo de diversas formas. Grundy (1987) ao apontar o caráter "quase natural" das propostas curriculares, ao afirmar que

o currículo não é um conceito, mas sim uma construção cultural. Isto é, não se trata de um conceito abstrato que tenha algum tipo de existência fora e previamente à experiência humana. É, antes, um modo de organizar uma série de práticas educativas. (GRUNDY, 1987, p.05).

chama à atenção para o caráter intencional e "não natural" do currículo, que é fundamentalmente constituído por escolhas relacionadas aos seus objetivos, conteúdos atividades, formas de avaliação etc.

Para Forquin (1993), o termo currículo, longe de ser compreendido como apenas uma listagem dos conteúdos que deverão ser desenvolvidos em certo período de tempo, deve ser entendido, a partir do vocabulário anglo-saxão, como

um percurso educacional, um conjunto contínuo de situações de aprendizagem ("learning experiences") às quais um indivíduo vê-se exposto ao longo de um dado período, no contexto de uma instituição de educação formal. (FORQUIN, 1993, p.22).

Portanto, sendo uma construção cultural, a elaboração e o desenvolvimento curricular, ou "o caminho" desse percurso educacional depende de decisões sobre os temas a serem abordados em detrimento de outros, seu encadeamento lógico, suas ênfases e, principalmente, sobre os pressupostos ou ideias-chaves relacionadas ao processo ensino-aprendizagem a ao objeto a ser estudado. 
Para que tais decisões possam ser tomadas, os elaboradores das propostas curriculares e, fundamentalmente, os professores (que são, em última análise, os responsáveis pelo desenvolvimento do currículo em sala de aula) utilizam-se de uma série de materiais de referência, tais como diretrizes e orientações oficiais, materiais de apoio, materiais de referência das disciplinas, dentre outros.

Dentre estes, o livro didático (LD) ocupa espaço destacado, pois pode ser considerado como uma das principais referências para a prática docente no Brasil, na medida em que cumpre o papel de organizador e orientador da sequência dos conteúdos e atividades a serem desenvolvidas (FREITAG, COSTA e MOTTA, 1997). Portanto, esse material orienta professores e alunos não só no que diz respeito à seleção dos conteúdos que deverão desenvolvidos e a ênfase dada a cada um deles, mas também à metodologia a ser seguida e às propostas de atividades que serão desenvolvidas em sala de aula.

Além disso, dada a diversidade e desigualdade existente no país, especificamente no que diz respeito ao acesso à informação e aos processos de formação docente, o LD ocupa, adicionalmente, um importante papel de referência teórica para muitos professores, que o utilizam como principal instrumento para sua própria formação.

O MEC explicita seu entendimento sobre o papel que o livro didático desempenha no desenvolvimento curricular:

\begin{abstract}
para cumprir seus objetivos didático-pedagógicos, o livro didático seleciona certos conteúdos em detrimento de outros, e os organiza de acordo com um determinado plano e sequência. Nesse sentido - e ocupando o lugar do professor - o LD: 1) efetua uma seleção da matéria a ser dada; 2) estabelece para ela certo tipo de abordagem e um tratamento e 3) propõe um trajeto próprio para sua exploração. (BRASIL, 2006, p.28, grifos nossos).
\end{abstract}

Somado a isso, os programas oficiais relacionados à compra e distribuição de LD para as escolas públicas, atualmente concentradas no Programa Nacional do Livro Didático (PNLD), em função de suas dimensões e importância, podem ser entendidos como uma das principais políticas desenvolvidas atualmente pelo MEC para a melhoria da educação nacional. Segundo dados de Fundo Nacional de Desenvolvimento da Educação (FNDE), somente no PNLD 2010 foram adquiridos cerca de 110 milhões de exemplares de livros didáticos e obras complementares, beneficiando cerca de 29 milhões de alunos, o que demonstra a magnitude e importância desses programas. (BRASIL, 2010).

Por se tratar de uma temática complexa e que possibilita diversas abordagens, os livros didáticos, em função dos conteúdos e temas abordados e sua lógica de desenvolvimento ou 
pelas atividades propostas, podem expressar diferentes concepções de saúde e diferentes compreensões dos fatores que influenciam ou determinam do processo saúde-doença.

Para Schall e Struchiner (1999), essas diversas maneiras de se compreender os aspectos que influenciam o processo saúde-doença orientam a educação dos temas relacionados à saúde na medida em que "espelham diferentes compreensões do mundo, demarcadas por distintas posições político-filosóficas sobre o homem e a sociedade." (SCHALL e STRUCHINER, 1999, p.04).

Portanto, sendo o livro didático um dos mais importantes recursos de apoio ao desenvolvimento curricular, pode-se dizer que influenciam de maneira decisiva no desenvolvimento dos temas de saúde em sala de aula e, consequentemente, na maneira pela qual os alunos e professores compreendem o processo saúde-doença e os fatores que o influenciam e determinam.

A partir do exposto, definimos algumas premissas que nortearam o presente trabalho, desde a formulação de questões iniciais que desencadearam a pesquisa até a formulação das categorias analíticas e dos planos de análise, assim como a análise e discussão dos resultados. São elas:

- A Saúde é um termo complexo e polissêmico, que pode ser compreendido de diversas formas e a partir de diversas concepções e visões de mundo. As propostas de educação em saúde, dentro e fora do ambiente escolar, são fortemente influenciadas em por essas distintas visões acerca do tema;

- O processo saúde-doença é multideterminado e influenciado por fatores de ordem natural (biológicos, fisiológicos, ambientais) e por fatores historicamente constituídos (culturais, socioeconômicos, hábitos, costumes, acesso aos bens e serviços etc.), sendo hierarquicamente distintos. Segundo o referencial do campo da Saúde Coletiva, e da Epidemiologia Social, os primeiros influenciam de maneira decisiva os segundos, não podendo ser considerados como pertencentes ao mesmo conjunto hierárquico. Além disso, o processo saúde-doença contempla e deve ser analisado tanto a partir de sua dimensão individual, quanto coletiva;

- À educação cabe propiciar condições para que os alunos se posicionem criticamente frente à realidade, inclusive no que diz respeito a sua situação de saúde, de sua família e comunidade. Para tanto, os fatores de diversas naturezas que influenciam a situação de saúde dos indivíduos, grupos específicos e da 
população em geral devem ser entendidos como objeto de estudo e aprendizagem por parte dos alunos;

- O livro didático desempenha papel destacado como material de apoio para os alunos e professores e influencia fortemente o desenvolvimento curricular. Dado seu papel, é objeto de um dos principais programas governamentais que visam à melhoria da Educação Básica no Brasil. O modo como a saúde é tratada nesse material define visões e concepções acerca do tema;

- A investigação com vistas à compreensão desses aspectos pode contribuir para a produção de conhecimento sobre o Livro Didático, especificamente no que tange as propostas relacionadas à saúde, assim como para o aperfeiçoamento desse material e qualificação do processo de desenvolvimento do tema em sala de aula.

Tendo como ponto de partida essas premissas, algumas questões, expostas a seguir, foram formuladas a fim de circunscrever o objeto e o problema a ser investigado:

- Como o tema da saúde é tratado nos livros didáticos para os anos iniciais do Ensino Fundamental?

- É possível identificar concepções hegemônicas relacionadas à saúde nesse material?

- Como os determinantes naturais e historicamente constituídos são abordados nos livros didáticos analisados? Qual é o papel atribuído a cada um deles?

- Em que medida as dimensões individual e coletiva estão contempladas na abordagem do tema? Qual é a ênfase dada a cada uma delas?

- É possível identificar "o currículo" ou "os currículos" de saúde para esse segmento, a partir do mapeamento dos temas abordados e do modo e momento em que são desenvolvidos?

Tanto essas premissas, quanto as questões acima apontadas serviram como "pano de fundo" e referencial para a investigação aqui proposta e, em função destas, foram formulados os objetivos do presente trabalho.

\subsection{Os Objetivos}

\subsubsection{Objetivo Geral}


Investigar como e a partir de que concepções os conteúdos relacionados à saúde humana são abordados nos livros didáticos de Ciências para os anos iniciais do Ensino Fundamental no Brasil.

\subsubsection{Objetivos específicos}

- Mapear os temas relacionados à saúde, sua frequência e os momentos em que são desenvolvidos nos livros didáticos de ciências para os anos iniciais do Ensino Fundamental;

- Analisar as concepções de saúde mais presentes nos livros didáticos para esse ciclo de escolarização, relacionando-as com os temas e objetivos pedagógicos;

- Analisar como os fatores que interferem no processo saúde-doença são apresentados nos livros didáticos, assim como a ênfase dada a cada um deles;

- Discutir possibilidades e implicações para o ensino dos temas relacionados à saúde nos anos iniciais do Ensino Fundamental.

\subsection{A estrutura do trabalho}

O presente texto está estruturado seguindo uma lógica que buscou partir de discussões de caráter mais amplo e seguir o caminho de aproximação ao objeto de investigação por meio de recortes cada vez mais delimitados.

Nesse sentido, o capítulo a seguir é voltado à discussão de aspectos relativos à saúde de modo geral, a fim de demarcar o campo teórico relacionado ao tema e as referências para a análise do material empírico. Nele são discutidas as diversas definições acerca do tema assim como a crítica feita a elas; as origens históricas dos modelos explicativos e teorias que foram formuladas ao longo do tempo a fim de compreender com se dá o processo saúde-doença; os modelos atuais no campo da Epidemiologia Social e, no caso brasileiro, da Saúde Coletiva, com ênfase na perspectiva da determinação social do processo e; a perspectiva da Promoção da Saúde, da prevenção de doenças, seus marcos teóricos, suas diferenças e estratégias de atuação.

O capítulo três é dedicado à discussão de como o tema da saúde adentra no ambiente escolar e se torna objeto de trabalho dos professores e de estudo e aprendizagem por parte dos alunos no Brasil. É apresentado um breve histórico desse processo, assim como uma discussão acerca da legislação e dos documentos de referência que vêm traçando as diretrizes 
para o ensino da saúde na escola e os reflexos que essas diretrizes podem ter na condução das atividades no ambiente escolar que, em última análise, irão conformar entendimentos distintos acerca do tema.

O capítulo seguinte é dedicado ao livro didático. Discute-se esse material como objeto de pesquisa, sua importância no mercado editorial, sua natureza fortemente influenciada pelo processo de elaboração e produção e, por fim, os programas oficiais de compra e distribuição desses livros e sua importância na atual política educacional brasileira.

O capítulo cinco é relativo ao percurso metodológico, onde são apresentados os referenciais e as categorias analíticas, descrito o material empírico que foi analisado, o processo de coleta sistematização e tratamento dos dados e, por fim, e os planos e a perspectivas de análise.

A seguir, no capítulo intitulado "A saúde nos livros didáticos para os anos iniciais do Ensino Fundamental", são apresentados e discutidos os resultados da análise do material empírico a partir de três perspectivas: a análise de cada coleção especificamente, a análise dos temas mais recorrentes e dos momentos em que esses aparecem nesse percurso educacional e a análise geral do conjunto das coleções.

Por fim, o último capítulo é dedicado às considerações finais, onde buscamos, , problematizar alguns aspectos que puderam ser vistos no trabalho, discutir algumas possíveis implicações para o ensino do tema da saúde em sala de aula, assim como apontar alguns recomendações relacionada à abordagem dos temas relativos à saúde nos livros didáticos. 


\section{SOBRE A SAÚDE}

\subsection{A saúde e o processo saúde-doença}

Não é tarefa simples definir o termo saúde, ou o binômio saúde/doença, assim como as diversas formas de compreender o processo de adoecimento que foram, ao longo da história, sendo construídas.

Somado a isso, as distintas compreensões a respeito da influência exercida pela gama de fatores, tanto internos quanto externos aos indivíduos, tanto naturais como historicamente constituídos que interferem na saúde humana conformam diferentes modelos explicativos desse processo, assim como orientam e definem estratégias de intervenção na realidade e práticas sociais, incluindo a educação.

Historicamente, as diversas sociedades procuraram compreender o estado de saúde das pessoas, assim como as causas do adoecimento, a fim de buscar "inferências causais para a doença" a partir de "diferentes maneiras de pensar o mundo, que traduzem projetos filosóficos diversos, quando não antagônicos.” (OLIVEIRA e EGRY, 2000, p.10).

Coelho e Almeida Filho (2002) apontam que a dificuldade epistemológica de conceituar saúde é reconhecida desde a Grécia Antiga e afirmam que, nos dias atuais, esse problema persiste e, dentre outros fatores, pode estar relacionado a "uma dificuldade do paradigma científico dominante, nos mais diversos campos científicos, de abordar a saúde positivamente", na medida em que tal paradigma enfatiza a "cultura da doença" (COELHO e ALMEIDA FILHO, 2002, p. 316).

Para Almeida Filho (2011), o termo saúde se refere a um conceito de interesse científico e filosófico, mas também a noções do discurso comum que são centrais para o imaginário social contemporâneo. Ao apresentar a complexidade e dificuldade na definição do termo, assim como seu caráter multifacetado e iminentemente transdisciplinar, o autor afirma que

a saúde constitui um objeto complexo, referenciado por meio de conceitos (pela linguagem comum e pela filosofia do conhecimento), apreensível empiricamente (pelas ciências biológicas e, em particular, pelas ciências clínicas), analisável (no plano lógico, matemático e probabilístico, pela epidemiologia) e perceptível por seus efeitos sobre as condições de vida dos 
sujeitos (pelas ciências sociais e humanas). (ALMEIDA FILHO, 2011, p.27).

A Organização Mundial da Saúde (OMS), ainda sob os efeitos da Segunda Guerra Mundial, definiu, em 1946, saúde como "o estado de completo bem-estar físico, mental e social, e não meramente a ausência de doença ou incapacidade" (WHO, 1946, p.100). Tal definição aparece no preâmbulo da Constituição da Assembleia Mundial da Saúde, que foi ratificada na Conferência Sanitária Internacional realizada em Nova York em 1946, entrando em vigor em 1948 e sofrendo poucas e pequenas emendas desde então. (CALLAHAN, 1973).

A definição da OMS vem, ao longo desse período, sendo alvo de severas críticas por autores que a consideram desprovida de rigor e materialidade, tendo um caráter profundamente individualizado, utópico e subjetivo, sob o argumento de que "o completo bem-estar" só pode ser aferido de maneira individual e subjetiva (ALMEIDA FILHO, 2000a; LUZ, 1986; dentre outros). Mesmo corroborando a crítica feita à definição, Sandra Caponi (1997) afirma que as observações relativas à sua dimensão subjetiva não são pertinentes, pois “o caráter subjetivo é inseparável do conceito de saúde e essa associação permanecerá qualquer que seja a sua definição.” (CAPONI, 1997, p.298).

Vale ressaltar que no texto da definição da OMS o termo, apesar de ter um caráter aparentemente positivo, é definido a partir de sua negação - "e não meramente pela ausência de doença" -, algo que explicita a dificuldade de definir o termo de maneira independente, ou seja, sem que seja colocada a sua relação intrínseca com a doença, seu caráter negativo.

Crítico importante dessa definição, Christophe Dejours (1986) aponta dois elementos fundamentais a serem questionados. O primeiro diz respeito à imprecisão do temo "bemestar" como algo impossível de ser definido, por ser muito vago. O segundo, relacionado a perspectiva da saúde como um processo e não um estado, aponta que a saúde aparece como algo que é possível alcançar e manter constante, como "se o estado de completo bem-estar físico, social e psíquico fosse um estado estável, que, uma vez atingido, pudesse ser mantido.” (DEJOURS, 1986, p.08).

Em 1943, em sua tese de doutorado que originou o clássico "O normal e o patológico" (CANGUILHEM, 2009), Georges Canguilhem (1904-1995) apresentou ideias que "contrariavam o pensamento dominante da época, segundo o qual os fenômenos patológicos seriam meras variações quantitativas dos fenômenos normais" (COELHO e ALMEIDA FILHO, 1999, p.17). Canguilhem apresenta como argumento principal a ideia de que os dois fenômenos (o normal e o patológico) são qualitativa, e não apenas quantitativamente 
diferentes e opostos. Somado a isso, questiona a dicotomia existente à época relacionada à definição dos estados normais/sãos dos anormais/patológicos. Afirma também ser impossível estabelecer normas (ou médias) coletivas que definam esses estados, na medida em que essas são dependentes das situações e limites vividos por cada indivíduo, a partir de suas características pessoais. Diz Canguilhem:

A fronteira entre o normal e o patológico é imprecisa para diversos indivíduos considerados simultaneamente, mas é perfeitamente precisa para um único e mesmo indivíduo considerado sucessivamente. Aquilo que é normal, apesar de ser normativo em determinadas condições, pode se tornar patológico em outra situação, se permanecer inalterado. O indivíduo é que avalia essa transformação porque é ele que sofre as consequências, no próprio momento em que se sente incapaz de realizar as tarefas que a nova situação lhe impõe. (CANGUILHEM, 2009, p.135).

Para ele, o estado anormal ou patológico nunca poderá ser aferido pela comparação com a média dos estados normais da população, e sim a partir de comparações individuais feitas sucessivamente. A partir dessas premissas, o autor afirma que "a doença não deixa de ser uma espécie de norma biológica. Consequentemente, o estado patológico não pode ser chamado de anormal no sentido absoluto, mas anormal apenas na relação com uma situação determinada." (CANGUILHEM, 2009, p.148).

O autor caracteriza a saúde como "a possibilidade de ultrapassar a norma que define o normal momentâneo, a possibilidade de tolerar infrações à norma habitual e de instruir novas normas em situações novas" (p.148), definindo-a como

um conjunto de seguranças e seguros, seguranças no presente e seguros para prevenir o futuro. Assim como há um seguro psicológico que não representa presunção, há um seguro biológico que não representa excesso. A saúde é um guia regulador das possibilidades de realização. (CANGUILHEM, 2009, p.149).

Nesse sentido, o ser saudável é aquele que, além de ter os dispositivos que necessita para viver em um dado contexto, tem também a possibilidade de enfrentar mudanças no meio ou as denominadas pelo autor como "infidelidades do meio", a fim de criar novas normas, ou seja, ser normativo. Para Canguilhem, "o normal é poder viver em um meio em que flutuações e novos acontecimentos são possíveis." (CANGUILHEM, 2009, p.148).

Caponi (2009) afirma que, a partir dessa visão,

não são as médias, nem a fuga dos intervalos assim chamados 'normais' que nos indicam o momento em que se inicia uma doença, mas sim as 
dificuldades que o organismo encontra para dar respostas às demandas que o meio lhe impõe. (p. 61).

Ao apresentar essa perspectiva "o pensamento canguilhemiano rompe com a visão característica do século XIX” (COELHO e ALMEIDA FILHO, 2002, p. 323), que, baseado no positivismo, compreende saúde como a adequação a uma norma, a um modelo predefinido e externo ao indivíduo.

Vale apontar que a obra de Canguilhem (especificamente "O Normal e o Patológico"), pode ser considerada fundamental para compreensão da saúde e da doença não como estados independentes, dicotômicos e estáveis, mas sim como um processo, um continnum permanente e dinâmico entre uma situação e outra. A partir dessa compreensão, "O normal e o patológico" se constituiu como referência para algumas das principais obras que demarcaram e ainda referenciam o campo teórico da saúde coletiva no Brasil ${ }^{2}$.

Retomando Dejours (1986), ao afirmar o caráter dinâmico do processo saúde-doença, assim como o papel do indivíduo na compreensão e avaliação de sua situação de saúde, é possível a proposição de quatro características (ou dimensões a serem levadas em conta) para a compreensão do conceito de saúde:

- A saúde não é algo que vem do exterior. Cada indivíduo tem sua própria saúde. A saúde "não é assunto de uma instância, de uma instituição ou dos médicos";

- A saúde é algo que se ganha, que se enfrenta e de que se depende. É algo em que o papel de cada homem, de cada pessoa é fundamental;

- A saúde não é um estado de estabilidade, não é estável. A saúde muda o tempo todo;

- A saúde é uma sucessão de compromissos assumidos com a realidade em suas diversas dimensões (com ambiente material, físico, químico e biológico; com a realidade afetiva, relacional, psíquica; com a realidade social). (DEJOURS, 1986, p.11).

O autor, ao propor uma definição para o termo, afirma que "a saúde para cada homem, mulher ou criança é ter os meios de traçar um caminho pessoal e original, em direção ao bemestar físico, psíquico e social” e que "a saúde, portanto, é possuir esses meios.” (DEJOURS, 1986, p.11).

\footnotetext{
${ }^{2}$ Entre essas obras referenciais do campo da Saúde Coletiva, pode-se citar: DONNANGELO, 1975; AYRES, 1997; CZERESNIA, 1997, AROUCA, 2003, dentre outros.
} 
Reafirmando o caráter complexo e subjetivo da saúde, assim como a dificuldade em dissociar a saúde da doença e, por outro lado, a necessidade de realizar essa dissociação, Almeida Filho (2000a) afirma que

no nível individual, a saúde não é um análogo inverso da doença. Se, para cada doença observa-se um modo prototípico de adoecer (cujo reconhecimento implica uma semiologia clínica), há infinitos modos de vida com saúde, tanto quanto seres sadios. (ALMEIDA FILHO, 2000a, p.09).

Ao analisar os diferentes modelos que tentam explicar a situação de saúde da população ou dos indivíduos, o mesmo autor aponta que a saúde vem sendo compreendida em diversos momentos e contextos históricos a partir de distintas perspectivas que podem ser agrupadas em seis grandes conjuntos (ALMEIDA FILHO, 2000b, 2000c, 2001 e 2011):

- Saúde como ausência de enfermidade: compreendida como um estado do indivíduo, a partir do entendimento clássico e dicotômico entre saúde e doença. Está embutida nessa concepção a ideia de saúde como um estado estável (e normal) e diametralmente oposto ao estado patológico (a anormalidade);

- Saúde como função ou desempenho: relacionada à ideia de capacidade/incapacidade, essa perspectiva é fortemente ligada à inserção social relacionada à capacidade de trabalho do indivíduo, entendido como "ser produtivo" na sociedade. Está ligada também à ideia de funcionamento do corpo, ou das funções por ele realizada. De acordo com Coelho e Almeida Filho (2002) tem sua origem na "teoria do papel do doente" de T. Parson";

- Saúde como equilíbrio (homeostase): presente desde os textos hipocráticos, essa percepção é baseada na ideia de equilíbrio relacionado tanto a elementos internos ao indivíduo (humores, fluídos), quanto ao equilíbrio entre o Homem e a Natureza, a partir dos seus elementos essenciais (água, fogo, ar e terra). Tal perspectiva, por exemplo, está na base da terapêutica das medicinas orientais, tais como a Ayuvérdica e a Unani (Índia) e a Medicina Tradicional Tibetana (BARROS, 2002). Atualmente abrange também a ideia de equilíbrio relacionado às funções orgânicas. Todas as patologias que se utilizam do sufixo dis (as disfunções) dizem respeito a essa perspectiva (CANGUILHEM, 2009);

${ }^{3}$ Parsons, T. The social system: Glencoe: Free Press, 1951. 
- Saúde como bem: relacionada à ideia de acesso aos bens e serviços de saúde. Essa perspectiva é a predominante nas análises dos sistemas e serviços de saúde, assim como à "produção em saúde"- entendida como o conjunto de procedimentos e bens relacionados à assistência à saúde - e também nos estudos referentes à economia da saúde. Nesse caso, a ideia de saúde é fortemente relacionada à assistência realizada pelos serviços e sistemas de saúde;

- Saúde como bem-estar: a partir da definição da Organização Mundial da Saúde, a saúde é compreendida como um estado relacionado às condições biológicas, psíquicas e sociais, procurando assim dissociar-se da doença. Como será discutido em item específico, o movimento da Promoção da Saúde baseiase nesse entendimento;

- Saúde como direito: inserida no conjunto de direitos individuais e coletivos, refere-se tanto às políticas que visam garantir condições para a manutenção e melhoria das condições de saúde, quanto à perspectiva de acesso universal aos serviços de saúde. Essa perspectiva é o fundamento da definição de saúde presente na Constituição Federal do Brasil (BRASIL, 1988), assim como da formulação dos princípios da universalidade de acesso, integralidade e equidade que são considerados como o arcabouço filosófico do Sistema Único de Saúde brasileiro (SUS). (BRASIL, 1990).

A despeito das dificuldades de se definir ou conceituar o termo, a preocupação com a compreensão dos modos de adoecer, assim como dos fatores que influenciam e determinam a situação de saúde, tanto no nível do indivíduo quanto das populações ou grupos populacionais, está presente desde a antiguidade. (ALMEIDA FILHO, 1999; NUNES, 2006).

\subsection{O processo saúde-doença e suas teorias explicativas}

Os discursos sobre saúde nunca se referem tão-somente a dimensões da saúde. Se tais discursos significam modos de pensar, escrever, falar sobre a saúde e suas práticas, é preciso situá-los em determinados momentos históricos e saber as razões por que se legitimam. (CASTIEL, 2007, p.25) 
Com o intuito de compreender como as diversas maneiras de interpretar o processo saúde-doença vêm influenciando as práticas sociais voltadas ao tema, inclusive com reflexos na educação, será apresentado um panorama das principais linhas de pensamento acerca dos modelos explicativos e dos fatores que interferem na situação de saúde que foram construídas ao longo da história.

Apesar do caráter cronológico da apresentação, não é objetivo apresentar tais perspectivas de modo a lhes conferir qualquer juízo de valor, na medida em que estas estão inseridas em contextos sociais e históricos distintos, que devem ser analisados a partir de suas características e especificidades. Não há, portanto, a ideia de sucessão ou evolução (entendida aqui como necessariamente "positiva") dos modelos explicativos, pois muitas dessas ideias foram concorrentes e simultâneas nos diversos momentos aqui analisados, assim como estão presentes nos dias de hoje. Nesse sentido, não nos propomos a qualquer tipo de comparação.

Adicionalmente, vale ressaltar que, em função do escopo da pesquisa, da dificuldade de acesso às informações, assim como de bibliografia disponível, nos restringiremos a discutir o denominado "pensamento ocidental", certos de que a compreensão desse fenômeno a partir da tradição oriental demandaria esforços que não se encaixam no presente trabalho.

Para Canguilhem (2009), até o século XIX as diversas formas de representação das doenças, assim como os fatores responsáveis pelo adoecimento, podem ser divididas em duas vertentes denominadas pelo autor como "ontológica" e "dinâmica", que são profundamente distintas entre si, mas que entendem ser a doença causada basicamente um único fator, portanto a partir de uma perspectiva unicausal. (CANGUILHEM, 2009).

\subsubsection{A Vertente Ontológica: a doença como um "mal", a perspectiva mágico- religiosa e as teorias miasmáticas}

A vertente ontológica tem sua origem nas práticas de cura do Egito Antigo e compreende a doença como uma entidade autônoma e externa ao homem, sendo a doença a “expressão ontológica do mal” (CANGUILHEM, 2009, p. 10). Por conseguinte, o doente é um ser humano no qual esse mal se agregou e o corpo humano é entendido como "um receptáculo de um elemento natural ou espírito sobrenatural que, invadindo-o, produz a doença." (OLIVEIRA e EGRY, 2000, p.10).

Quanto ao "elemento natural", historicamente as doenças parasitárias foram compreendidas como as expressões dessa "entidade do mal" que entrou no homem, pois são 
os parasitas (organismos externos e autônomos ao homem) os seres que o invadem e causam a doença. Henry Sigerist, citado por Canguilhem, afirma que "a medicina egípcia provavelmente generalizou a experiência de tratamento das afecções parasitárias combinandoa com a ideia de doença-possessão. Expulsar vermes é recuperar a saúde.” (SIGERIST, 19324, citado por CANGUILHEM, 2009, p.09). Assim, "a doença entra e sai do homem como por uma porta", e a cura está baseada na ideia de que se o doente é "um homem diminuído ou aumentado em algo, tudo o que ele perdeu pode ser restituído; o que nele entrou pode sair." (CANGUILHEM, 2009, p.09).

Quanto ao elemento sobrenatural, a causa de um mal (ou da doença) em um indivíduo ou população tem origem em algum tipo de fator que extrapola a natureza, que pode estar relacionado a encantamentos, feitiços e magias. Diz Canguilhem:

mesmo se a doença é sortilégio, encantamento, possessão demoníaca, podese ter a esperança de vencê-la [...]. A magia oferece inúmeros recursos para comunicar às drogas e aos ritos de encantamento toda a intensidade do desejo de cura. (CANGUILHEM, 2009, p 09).

Esses males de origem sobrenatural também dizem respeito "às transgressões de natureza individual ou coletiva" (BARROS, 2002, p.68). Nesse sentido, o doente, ou doentes, são os culpados por sua boa ou má sorte, pois a doença é compreendida como punição pelas faltas ou pecados cometidos, sendo esta punição posta em prática por entidades sobrenaturais ou divinas. A terapêutica, nesse caso, é baseada em ritos conduzidos por iniciados, pois para livrar-se do mal, ou curar-se, "é requerido reatar o enlace com as divindades por meio de rituais conduzidos por sacerdotes, iniciados ou xamãs, responsáveis por aplacar essas forças sobrenaturais." (BARROS, 2002, p.06).

Com a hegemonia do cristianismo na Europa durante Idade Média, apesar da existência de outras correntes de pensamento que entendiam o processo de adoecimento vinculado a aspectos naturais (especialmente aquelas ancoradas nos princípios hipocráticos), houve um predomínio das explicações mágico-religiosas do processo saúde-doença. A doença era atribuída às influências cósmicas, à bruxaria ou ao envenenamento da água e do ar, “especialmente realizada por grupos estigmatizados, como judeus e leprosos." (OLIVEIRA e EGRY, 2000, p.11).

\footnotetext{
${ }^{4}$ SIGERIST, H. E. Introduction a la Médecine. Paris: Payot, 1932.
} 
Além disso, em função da ideologia proposta pela igreja católica, ao afirmar a preocupação fundamental com a salvação do espírito, houve um relativo retrocesso quanto aos cuidados com o corpo, assim como com a preocupação em compreender o seu processo de adoecimento. (OLIVEIRA e EGRY, 2000; WESTPHAL, 2006). O mais importante era a salvação do espírito, sendo o corpo considerado apenas um veículo ou receptáculo.

Nesse contexto, o processo de adoecimento passou a ser entendido como punição ou castigo (por parte de entidades sobrenaturais) em função de pecados ou faltas cometidas. Esse entendimento persiste até os dias de hoje e pode ser visto tanto nas manifestações bastante comuns que relacionam a doença a comportamentos considerados reprováveis ou pecaminosos, quanto na busca por espaços de cura relacionados a entidades ou divindades sobrenaturais, mediadas por iniciados seja dentro ou fora dos templos.

A esse respeito, Sevalho (1993) cita como exemplos atuais dessa compreensão as reações sociais ocorridas quando da epidemia de sífilis o início do século XX, ou relacionadas ao surgimento da Aids nos anos de 1980. Em função de sua natureza de doenças sexualmente transmissível e da associação com "práticas pecaminosas", essas doenças suscitaram preconceito e estigmas a grupos considerados como promíscuos que praticavam atitudes reprovadas socialmente (como grupos de homossexuais masculinos e usuários de drogas injetáveis ou não, no caso da Aids), relacionadas muitas vezes à ideia de pecado e, portanto, passíveis de punição, inclusive por meio de doenças.

Sendo a cura de responsabilidade de iniciados, não é por acaso que durante o fim da Idade Média, e sob o controle da igreja católica, que surgem os hospitais na Europa. Nesse período, tais instituições não tinham como função curar a doença e sim ser um local de abrigo e conforto para os doentes, principalmente os pobres, tendo como objetivo principal isolar os doentes a fim de propiciar certo grau de segurança aos não doentes.

A esse respeito, Foucault (1979) aponta que "o hospital que funcionava na Europa desde a Idade Média não era, de modo algum, um meio de cura, não era concebido para curar" (FOUCAULT, 1979, p.101) e segue seu raciocínio afirmando que

antes do século XVIII, o hospital era essencialmente uma instituição de assistência aos pobres. Instituição de assistência, como de exclusão. O pobre, como pobre, tem a necessidade de assistência e, como doente, portador de doença e de possível contágio, é perigoso [...], é alguém que está morrendo e que deve ser assistido material e espiritualmente, alguém a quem se deve dar os últimos cuidados e o último sacramento. [...] dizia-se, nesta época, que o hospital era um morredouro, um lugar para morrer. (FOUCAULT, 1979, p.101). 
Mesmo com o pensamento hegemônico que relacionava a doença a um mal, nesse mesmo período a igreja católica na Europa associava a saúde com a ideia de equilíbrio/desequilíbrio, fazendo relação, portanto com sua vertente dinâmica. No entanto, mesmo nesse caso, as causas eram associadas à ideia de pecado (tais como a gula ou a luxúria) e as recomendações preconizadas para a boa saúde ou para a cura diziam respeito à "temperança no comer e no beber, na contenção sexual e no controle das paixões. Procuravase evitar o contra naturam vivere (viver contra a natureza)." (SCLIAR, 2007, p.33).

O mesmo autor esclarece que ainda nesse período é importante ressaltar os trabalhos de Paracelsus (1493-1541) que, baseado na alquimia, afirmava serem as doenças causadas por agentes externos ao organismo e que se os processos que ocorrem no corpo humano são químicos os melhores remédios para expulsar a doença seriam também químicos. Como tratamento de bastante sucesso, e que confirmava esse caráter da doença, "Paracelsus passou a administrar pequenas doses de minerais e metais, notadamente o mercúrio, empregado no tratamento da sífilis, doença que tinha se tornado epidêmica na Europa.” (SCLIAR, 2007, p.34).

Outra explicação de caráter ontológico da doença diz respeito às teorias formuladas anteriormente à descoberta do caráter patogênico de alguns microrganismos (e da relação entre a presença de certos micróbios e o estado de saúde ou doença) no século XIX. Tendo como premissa a ideia de que as doenças eram transmitidas pelo ar, esse conjunto de explicações originou a formulação de "teorias miasmáticas", que entendiam ser a doença causada basicamente por emanações de regiões insalubres, sendo o ar o principal veículo responsável por sua propagação.

Os miasmas eram entendidos como "telúricos, emanados das fendas e dos pântanos, [...] geralmente ligados aos excrementos humanos depositados na terra e à putrefação." (SEVALHO, 1993, p.539). A partir dessa compreensão, os locais de grande concentração humana e principalmente de confinamento (aglomerados urbanos, navios, prisões etc.), além dos cemitérios, passaram a ser considerados como focos de transmissão de doenças e um perigo para a população considerada saudável. (FOULCAULT, 1979).

Sevalho (1993) aponta a persistência e a força que esse entendimento sobre a doença ligado às emanações ou miasmas teve ao longo da história ao afirmar que

apesar da formulação de uma teoria dos miasmas ser geralmente atribuída a Giovanni Maria Lancisi, nos séculos XVII e XVIII, com o seu estudo sobre a malária como um conjunto de febres dos pântanos, os 'maus ares' já eram 
temidos há muito. Estavam presentes nas representações de saúde e doença dos egípcios antigos; das obras de saneamento e urbanização da Roma antiga; dos "ares, águas e lugares" dos gregos hipocráticos e de suas fogueiras purificadoras; do medo que dominou os medievais durante a peste negra; de Fracastoro e suas ideias sobre o contágio; dos escritos precursores de Paracelso sobre as doenças dos mineiros; das doenças ocupacionais de Bernardino Ramazzini em 1700. (SEVALHO, 1993, p.538).

A teoria miasmática permaneceu como uma explicação válida e bastante forte para a compreensão dos mecanismos que levam ao adoecimento até a segunda metade do século XIX, quando as descobertas de Robert Koch (1843-1910) e Louis Pasteur (1822-1895) explicitaram o estabelecimento do vínculo causal entre a presença de certos microrganismos e estados patológicos, passando a dar lugar à denominada "Teoria Microbiana". No entanto, o debate teórico sobre a influência dos miasmas ou do micróbio na constituição dos estados patológicos percorre todo o século XIX e início do XX, tendo como exemplo o fato de que nessa época algumas doenças eram descritas como miasmático-contagiosas. (NUNES, 1998; SEVALHO, 1993). Tal concomitância de teorias explicativas tinha reflexos no cotidiano do início do século XX, inclusive no Brasil, como, por exemplo, "na propaganda de diversos desinfetantes, [onde] as palavras micróbio, germe e miasma apareciam alinhadas em uma mesma frase e vistas como similares." (SANT'ANNA, 2011, p.308).

\subsubsection{A vertente dinâmica: a saúde como equilíbrio e a tradição hipocrática}

A segunda vertente, presente desde a antiguidade e denominada por Canguilhem como "dinâmica", diz respeito à ideia de que a saúde e a doença são decorrentes de estados de equilíbrio ou desequilíbrio.

Originária da medicina grega, especialmente dos escritos hipocráticos, entende que a natureza (physis), tanto do homem quanto fora dele, é harmonia e equilíbrio "e a perturbação desse equilíbrio, dessa harmonia, é a doença" (CANGUILHEM, 2009, p.10). Na sua origem, a relação com o equilíbrio interno diz respeito aos quatro principais fluídos (humores) do corpo: a bile amarela, a bile negra, a fleugma e o sangue, que, por sua vez, estão relacionados a quatro elementos naturais, respectivamente o fogo, a terra, o ar e a água. Explicitando e estreitando ainda mais a relação com a natureza, esses elementos e humores, por sua vez, são relacionados a cada uma das estações do ano: verão (bile amarela), outono (bile negra), primavera (sangue) e inverno (fleugma) (BARROS, 2002; SCLIAR, 2007).

A partir dessa ideia de equilíbrio, Canguilhem aponta que, na tradição hipocrática 
a doença não é somente desequilíbrio ou desarmonia; ela é também, e talvez sobretudo, o esforço que a natureza exerce no homem para obter um novo equilíbrio. A doença é uma reação generalizada com intenção de cura. (CANGUILHEM, 2009, p.10).

A cura, a partir dessa compreensão, deve ser alcançada pelo restabelecimento do equilíbrio "que deveria ser perseguido, através dos cuidados com o corpo, hábitos alimentares e exercícios físicos, em uma convivência harmônica com o ambiente natural, onde o ser humano era visto como parte integrada desta natureza." (SEVALHO, 1993, p.353).

É possível vislumbrar claramente nessa perspectiva as origens da definição de saúde formulada pela OMS de "completo bem-estar", assim como as ideias relacionadas aos hábitos e estilos de vida saudáveis como fatores fundamentais para a saúde, que se constituem atualmente como algumas das principais palavras de ordem de algumas políticas atuais no campo da saúde pública. Para Caponi (1997, p.210), essa maneira de enxergar a saúde como equilíbrio entre o organismo e o meio "é, talvez, o modo mais clássico e antigo de conceituar saúde" e "permanece, mesmo que transformada, até os nossos dias".

A principal diferença entre essa vertente e a visão ontológica é que, a partir de um forte componente empírico de observação da natureza, a saúde e a doença passam a ser entendidas como resultantes de aspectos naturais (e não sobrenaturais) e concebidas como decorrentes da relação entre o homem e o ambiente. Somado a esse aspecto, a vertente dinâmica se baseia na ideia de que a doença é parte do homem e não está fora dele, não é um ente ou entidade autônomo, "está em todo o homem e é toda dele." (CANGUILHEM, 2009, p.10).

Sergio Arouca (2003), baseando-se de Entralgo ${ }^{5}$, sintetiza de maneira bastante clara a maneira como essas duas vertentes da saúde e da doença aparecem nas principais correntes de pensamento sobre o processo de adoecimento ao longo da história.

O autor aponta que, no tocante à vertente ontológica, podem ser elencadas as seguintes teorias e autores:

As interpretações no período pré-científico, como a perda da alma do paciente, como a penetração mágica de um objeto ou a possessão por maus espíritos (perspectiva mágico-religiosa);

\footnotetext{
5 ENTRALGO, P.L. Concepto de la Salud y Enfermedad. In: BALCELLS, C. A. et alli. Patologia general; etiologya e fisiopatologia. $3^{\mathrm{a}}$. ed. Barcelona, Toroy, t.1. 1970.p.1-18.
} 
- O Ontologismo Nosológico de Paracelso, Van Helmut e John, no século $\mathrm{XV}$, que acreditavam na existência de um parasita invisível dentro do organismo;

- $\quad$ O Reativismo de Sydenhan (século XVII), que interpreta a doença como o esforço do organismo para libertar-se da "matéria mórbida";

- A Teoria Microbiana de Pasteur, Koch e Klebs do século XIX. O micróbio como o responsável pela doença e estabelecimento do nexo causal entre sua presença e alguns estados patológicos.

Quanto às teorias baseadas na vertente dinâmica, Arouca aponta como principais:

- A medicina grega, desde Alemenon de Cróton (500 anos A.C.), que considerava ser a doença uma desordem da physis do homem afetado, que influenciou a medicina Hipocrática, também baseada na ideia de equilíbrio;

- A Teoria Celular de Morgani, Bichat, Laennec, Rokitansky e Charcot (séc. XIX), que acreditavam estar no padecimento e adoecimento celular a essência da doença;

- A Patologia Constitucional de Nicola Pende e Viola (sec. XIX), que valoriza a constituição natural dos indivíduos (biótipos e marcadores corporais, assim como características étnicas) para explicar as diferentes enfermidades, assim como as pré-disposições para atos antissociais ${ }^{6}$.

Essas duas vertentes não podem ser vistas como ultrapassadas nem tampouco como sem influência nos dias de hoje. A respeito disso, utilizaremos novamente Canguilhem quando aponta que

O pensamento médico oscila, até hoje, entre essas duas representações da doença encontrando, de cada vez, para uma ou outra atitude, alguma boa razão em uma patogenia recentemente elucidada. As doenças de carências e todas as doenças infecciosas ou parasitárias fazem a teoria ontológica marcar um ponto; as perturbações endócrinas e todas as doenças marcadas pelo prefixo dis reafirmam a teoria dinamista ou funcional. [...]. Como ponto em comum, essas duas concepções encaram a doença, ou a experiência de estar doente, como uma situação polêmica, seja na luta do organismo contra um

\footnotetext{
${ }^{6} \mathrm{~A}$ relação entre os atos antissociais e a doença, assim como o caráter patológico do crime, toma contornos científicos a partir da obra de Cesare Lombroso (1858-1909), que originou a denominada Escola Positiva na criminologia. A influência dessa escola no Brasil, especialmente em São Paulo no início do século XX, está bastante bem discutida em FERLA, L. (2009).
} 
estranho, seja na luta interna de forças que se afrontam. (CANGUILHEM, 2009, p. 11).

\subsubsection{O Século XIX: o estudo científico da sociedade, as bases da medicina social e a relação saúde e condições de vida}

Segundo Foucault (1979), a partir do final do século XVIII e, principalmente, durante o século XIX, em um período de consolidação do capitalismo, da constituição dos Estadosnação no continente europeu e da expansão e crescimento das cidades, é que se inicia um processo de estudo científico e metódico da sociedade, por meio de diversas estratégias e ciências, dentre as quais a estatística e a medicina social.

O autor justifica essa necessidade a partir de três preocupações básicas: a necessidade de normatização da sociedade e fortalecimento do Estado, a partir do conhecimento de sua população, originando a "medicina de Estado"; o crescimento das cidades e o surgimento do "medo urbano" - caracterizado por "certo número de pequenos pânicos que atravessam a vida urbana das grandes cidades" (FOUCAULT, 1979, p.87) - dando origem à "medicina urbana"; e a crescente constituição da massa de trabalhadores urbanos que se configurará futuramente como proletariado, criando as bases para a "medicina da força de trabalho". (FOUCAULT, 1979, p.85 e seguintes).

Este contexto favoreceu a penetração do conhecimento médico no domínio do ambiente social e pôde ser visto em três contextos bastante claros: a polícia médica alemã no século XVIII, que se configurou como uma medicina de Estado capaz de instituir medidas compulsórias de controle de doenças; a medicina urbana francesa (século XVIII), que desencadeou o processo de saneamento arquitetônico e urbanístico das cidades, entendidas como estruturas espaciais que buscavam uma nova identidade social; e a medicina da força de trabalho na Inglaterra industrial no século XIX, que teve como marco a promulgação da "Lei dos Pobres" nesse país. (FOUCAULT, 1979; SEVALHO, 1993).

A partir desse momento, as condições de saúde da população se tornaram de interesse dos governos, passando a sociedade a ser estudada de maneira sistematizada. Ao afirmar o caráter político do estudo das condições de saúde da população nesse período, Barata (2005) afirma que

é durante o século XIX que a sociedade passa a ser estudada cientificamente. A investigação e quantificação dos eventos vitais (nascimentos e óbitos), que 
vinham sendo realizadas desde séculos anteriores, forneciam evidências de que a observação dos padrões populacionais era útil para a compreensão dos processos de adoecimentos. (BARATA, 2005, p.09).

Nesse contexto começam a surgir os primeiros ensaios acerca da relação entre a situação de saúde de grupos populacionais e suas condições de vida, principalmente nas áreas urbanas. Para Ayres e colaboradores,

os primeiros saberes com pretensões de cientificidade de traços modernos voltados para a apreensão dos fenômenos coletivos de saúde podem ser localizados na higiene social do período pós-revolucionário na França a partir dos estudos de Villermé. ${ }^{7}$ (AYRES et. al., 2006, p.378).

Alguns estudos desse período que tiveram por objetivo relacionar as condições de vida com a situação de saúde são considerados clássicos na constituição da Epidemiologia como disciplina científica. Além dos trabalhos de Villermé em Paris, pode-se citar o estudo clássico John Snow (1813-1863) que, em 1831, relacionou a localização das fontes de abastecimento de água e a epidemia de cólera em Londres; o trabalho de Rudolf Virchow (1821- 1902) acerca da epidemia de febre tifoide ocorrida em 1847 em trabalhadores de minas de carvão na Silésia (região localizada entre a Polônia e Republica Tcheca) e o trabalho de Friedrich Engels (1820-1895), datado de 1884, sobre a relação entre as taxas de mortalidade e condições de vida das classes operárias na Inglaterra.

O trabalho de Snow é considerado emblemático e seu autor é considerado o "pai da epidemiologia", pois traz pela primeira vez nitidamente o que Ayres e colaboradores apontam como "eixo triádico" do pensamento epidemiológico:

o controle técnico dos agravos de saúde como interesse prático; o comportamento coletivo dos fenômenos patológicos como base empírica de suas interrogações e proposições; e a variação quantitativa como linguagem que mais autenticamente expressava a possibilidade de apreender e intervir sobre tais fenômenos coletivos para seu controle técnico. (AYRES et. al., 2006, p.378)

Esses trabalhos, assim como as questões apresentadas por Foucault, anunciavam claramente a preocupação em relacionar as condições de vida de um grupo ou população com sua situação de saúde, na medida em que buscavam compreender como as condições históricas, geográficas e sociais se relacionavam com o surgimento das doenças

${ }^{7}$ Louis-René Villermé (1782-1863), em 1826, relacionou as taxas de mortalidade geral nos bairros parisienses à proporção de rendas não taxadas da população, tomada como indicador do grau de riqueza ou pobreza desses bairros. (BARATA, 2006). 
(CZERESNIA, 2008). Além disso, as evidências desses trabalhos mostravam que essas associações entre condições de vida e situação de saúde eram bastante mais claras quando relacionadas à pobreza ou às condições de trabalho.

A preocupação com o estabelecimento dessas relações, somada à repercussão causada pelos trabalhos citados, conformava uma forte corrente do pensamento médico da época, que compreendia a medicina como uma ciência de natureza profundamente social. Afirmando essa situação, Barata aponta que "essa relação inicial entre a Epidemiologia e as Ciências Sociais na busca de explicações para os padrões populacionais de distribuição das doenças perdura durante a maior parte do século XIX.” (BARATA, 2005, p.09).

A partir de seus trabalhos, Virchow buscou radicalizar a relação existente entre a medicina e a sociedade a partir da formulação de uma teoria da doença epidêmica como manifestação do desajuste social. Dizia: "se a doença é uma expressão da vida individual sob condições desfavoráveis, a epidemia deve ser indicativa de distúrbios em maior escala da vida da massa." (VIRCHOW, $1849^{8}$, citado por ROSEN, 1980, p.83).

No tocante às epidemias, Virchow dizia que

pode-se apontar como suas causas as condições atmosféricas, as mudanças cósmicas gerais e coisas parecidas, mas em si e por si estes problemas nunca causam epidemias. Só podem produzi-las onde, devido às condições sociais de pobreza, o povo viveu durante muito tempo em uma situação anormal. (VIRCHOW, $1851^{9}$, citado por ROSEN, 1980, p. 83).

A partir desse princípio, o autor propunha a diferenciação entre as "epidemias naturais", daquelas que denominou como "epidemias artificiais". Quanto as primeiras, Virchow as definia como aquelas que "sempre ocorrem quando mudanças de estação, de tempo etc. alteram as condições de vida e a grande massa não se protegeu por meios artificiais (febres intermitentes e pneumonias, por exemplo)". No que tange às "artificiais", dizia estarem relacionadas "aos atributos da sociedade, produtos de uma falsa cultura ou de uma cultura não acessível a todas as classes que afetam predominantemente aquelas classes que não participam dos benefícios da cultura (por exemplo, tifo, escorbuto, suor maligno e tuberculose)." (VIRCHOW, 1849, citado por ROSEN, 1980, p.84).

\footnotetext{
${ }^{8}$ Virchow, R. Die Einheitsbestrebungen in der wissenschftlicher Medicin. Berlim: Druck und Verlag von G. Reimer, 1849, p. 48 (em Rosen, 1980, p.84).

${ }^{9}$ Virchow, R. Die Epidemien von 1848 (Gelesen in der Jahressitzung der Gesellschaft für wissenschaftliche Medic. am 27 novb.1848) Archiv für pathologische Anatomie und Prysiologie und für klinische Medicn, 3 p. 03-12. 1851.(em Rosen, 1980, p.83).
} 
O fato é que, a despeito da relação bem estabelecida entre as condições de vida e a situação de saúde dos indivíduos e populações, além da descrição dos veículos e dos meios causadores das epidemias - como as fontes de água em Snow, por exemplo -, esses diversos trabalhos careciam de uma resposta precisa acerca dos agentes que causavam o estado patológico, na medida em que relacionavam o adoecimento a fatores bastante genéricos como influências ou miasmas. Tal fato passará a ser entendido como um "ponto fraco" e alvo da crítica a essas teorias, que se radicalizará principalmente a partir das descobertas de Louis Pasteur e Robert Koch e a constituição das bases da teoria que viria a ser conhecida como Teoria Microbiana da Doença.

Em um ensaio de 1893 que tratava da terapia etiológica das doenças infecciosas, Emil Behring (Prêmio Nobel de Fisiologia ou Medicina em 1901), utilizou-se do estudo de Virchow sobre a febre tifoide que propunha como estratégia de melhoria das condições de saúde da população estudada "uma radical reforma social que compreendia democracia completa e irrestrita, educação, liberdade e prosperidade" (ROSEN, 1980, p.78), para dizer "ser característico do pensamento médico do começo do século XIX a associação causal entre miséria social e doença." (BEHRING, $1893^{10}$, citado por ROSEN, 1980, p.78).

No entanto, mesmo utilizando-se desse exemplo para expor suas teses, o autor fazia sérias restrições à ideia de transformações sociais para lidar com a doença, ao afirmar que

de acordo com os procedimentos de Robert Koch, o estudo das doenças infecciosas podia ser levado adiante sem a necessidade de um desvio para considerações e reflexões sociais sobre a política social. (BEHRING, 1893 citado por ROSEN, 1980, p.79, grifo nosso).

Rosen (1980) aponta de maneira bastante clara as profundas diferenças existentes entre pensamento de Virchow e de Behring no que diz respeito à própria definiç̧ão da doença, assim como do papel desempenhados por os diversos fatores na constituição dos estados patológicos, ao afirmar que "Virchow reconhecia as descobertas dos bacteriologistas, mas nunca poderia aceitar uma relação causal absoluta entre bactéria e doença. Para ele, o bacilo da tuberculose não era idêntico à tuberculose.” (ROSEN, 1980, p.88).

O autor utiliza-se desse exemplo para perguntar: "qual o sentido dessa profunda clivagem entre Behring e Virchow?” (ROSEN, 1980, p.79). Segundo ele, a raiz dessa

\footnotetext{
${ }^{10}$ E. Behring. Gesammelte Abhanlungen zur ätiologischen: Therapie von Ansteckenden Krankheiten. Leipizig: Georg Thieme, 1893, p. xvii (em Rosen, 1980, p.78).
} 
diferença está justamente na concepção do papel da medicina na sociedade, da própria natureza dessa ciência, assim como das ações e estratégias que competem a ela.

Essa diferença de perspectiva apontada por Rosen reflete claramente as diferentes concepções sobre as causas do adoecimento em indivíduos e populações, assim como sobre as estratégias para melhoria da situação de saúde das pessoas que passaram a disputar a hegemonia do campo da saúde a partir do século XIX e que são foco de tensões ainda nos dias de hoje. Ou seja, tais tensões refletem diferentes entendimentos sobre os fatores primordiais e essenciais de determinação do processo saúde-doença, sobre o papel da medicina (e do setor saúde em geral) na sociedade e, em última análise, sobre o próprio conceito de saúde e, consequentemente, de doença.

\subsubsection{A descoberta do caráter patogênico dos micróbios, o Relatório Flexner e a constituição do modelo biomédico}

Influenciada pelo paradigma cartesiano, a Europa vivia no final do século XIX um momento de constituição de disciplinas científicas tais como a anatomia, a fisiologia e a patologia, assim como de definição das bases do método científico baseado fortemente na corrente positivista. Nesse cenário, as obras de Augusto Comte (1798-1857) relativas ao fenômeno patológico, assim como as de Claude Bernard (1813-1878) com seu laboratório de fisiopatologia, passam a ter grande influência no pensamento a respeito da saúde a da doença. A partir desse período e mediado por essas influências, o fenômeno patológico passou a ser estudado mediante "argumentos controláveis, protocolos de experiências, e, sobretudo métodos de quantificação.” (CANGUILHEM, 2009, p.42).

Koifman (2001) aponta a influência desse tipo de pensamento na constituição das chamadas "disciplinas médicas", assim como no estudo das doenças ao afirmar que

\footnotetext{
na anatomia clínica do século XIX, o aprendizado das doenças se fez não pela observação da vida, mesmo que em corpos doentes, mas em corpos mortos. Assim, a saúde passou a ser vista como ausência de doença e a cura passou a significar a eliminação dos sintomas. (KOIFMAN, 2001, p. 51).
}

Além disso, a partir das obras de Renè Laennec sobre o diagnóstico individual e de François Bichat, com o estudo das doenças nos tecidos, passaram a ser aceitas novas concepções que tinham em comum a "negação da medicina como ciência da sociedade." (KOIFAN, 2001, p.56). Portanto, é a partir desse período na Europa que passa a se configurar um pensamento médico diametralmente oposto àquele que vinha sendo formulado por 
Virchow, Snow e outros autores, que compreendia a medicina como uma ciência eminentemente social e procurava relacionar as condições sociais e a situação de saúde dos indivíduos e grupos.

É nesse contexto que as descobertas de Koch na Alemanha e de Pasteur na França acerca da existência de microrganismos (micróbios) na base de certas doenças, assim como o estabelecimento de sua relação direta, portanto causal, com os estados patológicos, passam a se tornar paradigmáticas para a explicação do fenômeno do adoecimento.

Canguilhem, ao discutir a respeito do "sucesso" da teoria microbiana e sua repercussão no pensamento médico, relaciona essa perspectiva ao entendimento ontológico da doença. Sem "querer atentar a majestade dos dogmas de Pasteur", o autor afirma que

a teoria microbiana das doenças infecciosas deve, certamente, uma parte considerável de seu sucesso ao fato de conter uma representação ontológica no mal. O micróbio, mesmo sendo necessária a mediação complicada do microscópio, dos corantes e das culturas, pode ser visto, ao passo que não se poderia ver um miasma ou uma influência. (CANGUILHEM, 2009, p.09$10)$.

Nesse mesmo sentido, Sevalho (1993) aponta que "o interesse de Koch pela fotografia e a oportunidade que teve de utilizar os aperfeiçoamentos da microscopia, possibilitaram a comprovação categórica da teoria dos germes [...]. Afinal, não se poderia fotografar um miasma ou uma influência." (p.360).

A partir dessa repercussão, o pensamento que vinha se conformando ao longo do século XIX acerca da relação entre condições de vida e situação de saúde das pessoas ou grupos é questionado em suas bases, assim como o conhecimento epidemiológico até ali acumulado sobre os fatores relacionados à ocorrência de doenças e sua determinação social (NUNES, 1998; BARRETO, 1990). É a partir desse momento que passa ser hegemônica a compreensão de que existe uma relação direta e um nexo causal entre a presença de um agente etiológico e uma doença.

Somado a isso, as enfermidades de maior prevalência na época, de natureza infectocontagiosa, favoreceram a hegemonia desse modelo explicativo. É nesse cenário que se consolida o conceito de unicausalidade - para cada doença um agente específico. (BARRETO, 1990; ALMEIDA FILHO, 1999).

A partir desse movimento, ao final do século XIX a emergência da teoria microbiana "faz obscurecer concepções que destacavam a multicausalidade das doenças ou que 
proclamavam a decisiva participação, na eclosão das mesmas, dos fatores de ordem socioeconômica." (BARROS, 2002, p.74). A partir desse movimento, os aspectos de ordem natural, ou seja, a presença ou não de agentes infecciosos específicos (agentes patogênicos), passam a ser tomados como os primordiais para o entendimento dos processos que definem as situações de saúde.

Assim, ideias como a de contágio e as relações causa-efeito passam a ser constituintes do campo de estudo das doenças em indivíduos e populações e "se estabelece um modelo epidemiológico como uma interação entre esses dois elementos [agente e hospedeiro] e o ambiente" (NUNES, 1998, p.109), definindo a denominada tríade epidemiológica, que se constitui como a base do pensamento epidemiológico clássico. (BARATA, 2005).

Outro processo relevante para a discussão aqui proposta e fundamental para a compreensão de como certo tipo de compreensão acerca do processo saúde-doença se tornou hegemônica no pensamento médico, diz respeito à realização nos Estados Unidos da América, no início do século XX, da primeira grande avaliação das escolas médicas da região.

Tal avaliação teve como objetivo traçar um panorama das escolas médicas nos Estado Unidos e no Canadá que passavam por um momento de bastante ecletismo, tanto no que diz respeito aos conteúdos, quanto às disciplinas oferecidas, cargas horárias, metodologias de ensino, instalações, infraestrutura etc. e podiam ser abertas indiscriminadamente, com ou sem equipamentos, articuladas ou não a instituições universitárias. (HIATT, 1999; KOIFMAN, 2001; PAGLIOSA e DA ROS, 2008).

Esse trabalho, encomendado pela Carnegie Foundation ao educador Abraham Flexner (1866-1959), resultou na publicação, em 1910, do estudo intitulado Medical Education in the United States of America - A Report to the Carnegie Foundation for the Advancement of Teaching, (FLEXNER, 1910), que mais tarde ficou mundialmente conhecido como Relatório Flexner (Flexner Report) (HIATT, 1999).

Para Hiatt “o Relatório Flexner é largamente considerado como [responsável por] uma das mais significativas reformas da educação médica no século XX.” (HIATT, 1999, p.18), principalmente em função de ser a ele atribuído o papel de ter levado profissionalismo e método científico à escola médica na América do Norte.

A despeito dessa importância e reconhecimento, principalmente relacionado à racionalidade científica necessária às escolas médicas, os métodos utilizados por Flexner para 
a avaliação são bastante questionáveis e sofrem severas críticas, especialmente no que tange ao seu caráter profundamente subjetivo, não sistemático e destituído de fundamento teórico.

Como exemplo d o caráter questionável dessa avaliação, Pagliosa e Da Ros (2008) apontam o fato de que Flexner vistoriou pessoalmente 155 escolas médicas nos EUA e no Canadá em um período de 180 dias. Além disso, ressaltam o caráter pouco preciso e de certa forma arbitrário do método utilizado, ao afirmarem que

Flexner desprezava qualquer esforço para validar os critérios ou o processo que empregava, insistindo em que os 'indicadores óbvios' que utilizava eram suficientes para formular um juízo de valor [...]. Em sua biografia, analisada por Hiatt, Flexner deixa claro a maneira como realizou a pesquisa: "em umas poucas horas, uma estimativa confiável pôde ser feita a respeito das possibilidades de ensinar medicina moderna em quase todas as 155 escolas que visitei." (PAGLIOSA e DA ROS, 2008, p.494).

Hiatt (1999) afirma do seguinte modo, e com certo tom de ironia, que o próprio Flexner admitiu posteriormente que o rigor com o método científico, algo que tanto proclamava como fundamental para as escolas médicas, teve pouca importância no seu processo avaliativo:

Flexner confessou que não usou nenhum tipo de questionário padronizado e nenhum método padrão de procedimentos [...]. Admitiu posteriormente que 'a inconsistência [metodológica da avaliação] nunca me incomodou'. Ele pôde visitar algumas escolas em pouco tempo e então voltou para Nova Iorque para por (seus) fatos em ordem. (HIATT, 1999, p.19).

Para o mesmo autor, o fato de Flexner ser um educador e, portanto, não ser médico, suscitou severas críticas da comunidade médica americana da época que entendiam que apenas os médicos seriam capazes de realizar tal avaliação. Além disso, ao afirmar que "seu relatório é produto de interesses suspeitos e motivos duvidosos” (p.18), Hiatt aponta os resultados da avaliação realizada por Flexner respondiam à época muito mais aos interesses econômicos das fundações - que passariam a ser responsáveis por grande parte dos orçamentos dessas escolas, dentre elas a Carnegie Foudation, responsável por sua contratação - do que a efetiva melhoria da qualidade das escolas médicas.

A respeito da repercussão do Relatório Flexner e sua influência na conformação de um determinado pensamento médico hegemônico dentro das escolas médicas, Pagliosa e Da Ros afirmam que

foi esta avaliação que se transformou no principal e praticamente único instrumento para a acreditação das escolas médicas nos Estados Unidos e 
Canadá, com implicações diretas em todo o mundo ocidental durante a primeira metade do século XX. (PAGLIOSA e DA ROS, 2008, p.494).

Afirmando que o objetivo central de seu relatório era imprimir uma racionalidade científica baseada em um forte componente positivista e, a partir desse pressuposto, qualificar o ensino médico, Flexner propunha, dentre outras coisas, um rigoroso controle de admissão, o currículo de quatro anos dividido em um ciclo básico (realizado no laboratório), seguido de um ciclo clínico no hospital e a exigência de laboratório e instalações adequadas. (PAGLIOSA e DA ROS, 2008).

É interessante destacar os aspectos do pensamento de Flexner relativos a quem se destina a escola médica, que definiram, inclusive, os processos de admissão nessas escolas. Para ele, a medicina (e, portanto, a escola médica) era prioritariamente destinada apenas às pessoas da elite, com o aproveitamento dos mais capazes e 'inteligentes'. (KEMP e EDLER, 2004).

A esse respeito, Flexner, em seu relatório, dedica capítulos específicos para apresentar propostas relacionadas às escolas médicas para as mulheres e para os negros. Aponta, além da necessidade de serem separadas das dos homens (brancos), a necessidade do estabelecimento de importantes limites de atuação desses profissionais, relacionados às "naturais características das mulheres" (FLEXNER, 1910, p.178) e a possibilidade de atuação de médicos negros. Quanto a esse último aspecto, é bastante claro ao afirmar que

the medical care of the negro race will never wholly left to negro physicians. Nevertheless, if the negro can be brought to feel a sharp responsibility for the physical integrity of his people, the outlook for their mental and moral improvement will be distinctly brightened. The practice of the negro will be limited to his own race [...]. Not only does the negro himself suffer from hookworm and tuberculosis, he communicates them to his white neighbors, precisely as the ignorant and unfortunates whites contaminated by him [...]. The negro must be educated not only for his sake, but for ours [...]. He has his rights and due and value as an individual; but he has, besides, the tremendous importance that belongs to a potential source of infection and contagion. (FLEXNER, 1910, p.180).

No que diz respeito à centralidade da doença como objeto da medicina e do conhecimento médico, "Flexner afirmava que o estudo da medicina deve ser centrado na doença, de forma individual e concreta" (PAGLIOSA e DA ROS, 2008, p.496), pois está é considerada um processo natural, biológico. Assim, a discussão sobre o social, o coletivo, o público e a comunidade têm pouca influência para o ensino médico, na medida em que são 
considerados pouco relevantes para a compreensão do processo saúde-doença. (SANTOS, 1986).

A partir das propostas feitas por Flexner e da influência de seu relatório nas escolas médicas, o hospital se transforma na principal instituição de transmissão do conhecimento médico durante todo o século XX, tornando-se assim o centro da escola médica. (PAGLIOSA e DA ROS, 2008, p. 496).

Reforçando essa visão acerca do processo saúde-doença e confirmando a repercussão do pensamento de Flexner, assim como sua influência na formação em saúde, Almeida Filho (1999, p.06) afirma que, tendo por base o conhecimento experimental originário de pesquisas laboratoriais, geralmente realizadas sobre doenças infecciosas, o "modelo conceitual flexneriano reforçava a separação entre individual e o coletivo, o privado e o público, o biológico e o social, o curativo e o preventivo.”.

É pertinente ressaltar que Pagliosa e Da Ros (2008) criticam a adoção do termo modelo flexneriano de formação médica que é adotado por alguns autores, pois entendem que há certo exagero nesse termo, na medida em que Flexner "nada mais fez do que legitimar, com suas pobres avaliações, um processo que já estava em andamento de forma irreversível, isto é, a consolidação do modelo científico na medicina." (PAGLIOSA e DA ROS, 2008 p.496).

Utilizaremos novamente esses autores quando sintetizam a "visão flexineriana", assim como as implicações de seu pensamento na educação médica durante o século passado. Tal visão acabou por conformar determinada compreensão acerca do processo saúde-doença e do papel e influência das diversas naturezas de fatores, tais como individuais/coletivas, naturais/sociais etc. na definição das situações de saúde que são hegemônicos até hoje. Dizem eles:

Mesmo que consideremos muito importante suas [do pensamento flexineriano] contribuições para a educação médica, a ênfase no modelo biomédico, centrado na doença e no hospital, conduziu os programas educacionais médicos a uma visão reducionista. Ao adotar o modelo saúdedoença unicausal, biologicista, a proposta de Flexner reserva pequeno espaço, se algum, para as dimensões social, psicológica e econômica da saúde e para a inclusão do amplo espectro da saúde, que vai muito além da medicina e seus médicos. Mesmo que, na retórica e tangencialmente, ele aborde questões mais amplas em alguns momentos de sua obra, elas jamais constituíram parte importante de suas propostas. (PAGLIOSA e DA ROS, 2008, p.496). 
Em síntese, pode-se dizer que as bases para o que foi denominado como modelo biomédico que, apesar das criticas, se mantém hegemônico ainda nos dias de hoje no campo da saúde (WESTPHAL, 2006; CAMARGO JUNIOR, 2005), foram lançadas a partir dos seguintes elementos: 1) um contexto de consolidação do método científico baseado principalmente nos princípios positivistas, assim como na crença da ciência como verdade absoluta; 2) a estruturação e avanço conceitual e metodológico de disciplinas como a anatomia, a fisiologia e a patologia; 3) as importantes descobertas realizadas na segunda metade do século XIX relativas ao caráter patogênico de alguns microrganismos e à relação bem estabelecida entre a presença desses e algumas importantes doenças e epidemias da época e; 4) uma mudança estrutural na escola médica norte-americana, que teve repercussão mundial e influenciou de maneira decisiva a estruturação do ensino médico e da formação geral em saúde.

Grosso modo, e de certa forma radicalizando-as, pode-se dizer que o modelo biomédico tem as seguintes características:

- A saúde e a doença são processos eminentemente biológicos. A explicação dos processos de adoecimento pode ser encontrada nos diversos níveis do indivíduo (sistemas, órgãos, tecidos etc.) a partir de lesões ou disfunções dos mesmos;

- O corpo é visto em suas partes e não como um todo. É bastante utilizada nesse modelo a metáfora do corpo como uma "máquina". A doença é o "mau funcionamento da máquina" e a cura é o seu reparo. A partir da especialização médica, o corpo passa a ser visto em suas partes (muitas vezes não relacionadas) e não mais como um conjunto unitário;

- A ênfase é na cura individual. Como o saber médico se encontra no hospital e centrado na doença, a principal preocupação é com a cura do indivíduo. O objetivo é a saúde individual, ficando os aspectos coletivos em um segundo plano. No plano da prevenção, a ênfase se dá na procura da modificação de comportamentos de risco e na adoção de comportamento protetores da saúde;

- O saber médico é o preponderante. A partir de um saber originário do hospital e baseado em uma especialização cada vez maior, caberá prioritariamente ao médico a definição dos melhores procedimentos e estratégias. Assim, a figura do médico ocupa um lugar de destaque em todos os segmentos de saúde, inclusive nos de planejamento, administração e de gestão; 
- O saber médico como um saber sobre a doença e não sobre a saúde. A partir do entendimento do corpo como um conjunto de partes, e tendo como principais características o saber hospitalar e a especialização, cada vez mais o foco de atenção passa a ser na doença (suas explicações, conhecimento sobre os agentes ou fatores, seus meios de cura) e não na saúde propriamente dita. Como já discutido, esse aspecto de centralidade da doença no pensamento em saúde pode ser considerado como uma das dificuldades de se definir o próprio termo saúde sem vinculá-lo ao adoecimento;

- A saúde e a doença são definidas a partir de uma relação basicamente unicausal. Para cada doença existe uma única ou mais importante explicação (ou causa). Mesmo que esse pensamento seja mais claro no que diz respeito às doenças infectocontagiosas, no caso das doenças crônico-degenerativas existe a tendência de atribuir a um único fator o aspecto mais importante ou de destaque em relação aos outros. A cura se dará a partir do enfrentamento desse fator;

- Existe uma dissociação entre o indivíduo e o contexto onde vive. Na medida em que a preocupação é com a cura individual, por meio de técnicas relativas aos processos biológicos do indivíduo, desvaloriza-se a influência do contexto e das condições de vida das pessoas e grupos.

- Os aspectos naturais são os mais importantes para a explicação do processo saúde-doença. Mesmo quando são levados em conta os aspectos historicamente constituídos para a explicação dos processos de adoecimento, esses são colocados num mesmo plano que os demais e, portanto não são entendidos como determinantes da situação de saúde. O exemplo de Behring, descrito anteriormente, é emblemático nesse sentido.

É importante ressaltar que a descrição dessas características não tem como objetivo atribuir qualquer juízo de valor ou desmerecer essa perspectiva. É inegável que o saber e a especialização médica, o conhecimento detalhado e aprofundado sobre a doença, seus sintomas e os fatores que as desencadeiam, bem como as técnicas e procedimentos de diagnóstico e tratamento são fundamentais e de importância inquestionável. O esforço é o de caracterizar e explorar as origens de um determinado pensamento acerca do processo saúdedoença, a fim de apontar seus limites e seus reflexos nas práticas sociais, inclusive as 
relacionadas a perspectivas educacionais voltadas à saúde e aos objetivos da denominada educação em saúde.

\subsubsection{As insuficiências do modelo biomédico e a retomada da perspectiva social.}

É a partir das primeiras décadas do século XX que o modelo biomédico e a compreensão da importância dos diversos fatores intervenientes do processo saúde-doença oriundos desse modelo passam a ser questionados, a partir de alguns aspectos que expuseram seus limites.

Um primeiro ponto a ser destacado relaciona-se ao aparente controle das principais epidemias de doenças infectocontagiosas da época (como a febre tifoide) e o avanço das doenças crônico-degenerativas, especialmente nos países desenvolvidos, configurando a denominada transição epidemiológica, que fez diminuir a importância da ideia do contágio para a definição das ações voltadas à saúde. Somado a isso, com o advento e a estruturação da psiquiatria, colocava-se em evidência que muitas doenças tinham causas psicológicas, explicitando ser impossível explicá-las a partir de uma causa fisiológica ou anatomicamente comprovada. (NUNES, 1998).

Adicionalmente, aspectos de ordem social e econômica do início do século XX podem explicar o que aqui denominamos como a "retomada" da preocupação com a relação entre as condições de vida e as situações de saúde. A partir dos anos de 1930, portanto em um momento diretamente posterior à crise do capitalismo em 1929 e ainda sob seus efeitos,

a crescente fragmentação do cuidado médico conduziu à ênfase em procedimentos complementares, a uma elevação dos custos e a uma elitização da assistência. Isto ocorreu justamente quando o sistema político do capitalismo em crise mais necessitava da saúde enquanto controle social. Nesse período, a crise das sociedades capitalistas ocidentais revelava uma incapacidade do sistema econômico em prover condições mínimas de vida e de saúde para a maioria da população. Nesse cenário é retomado o caráter social do processo saúde-doença, assim como da medicina. (ALMEIDA FILHO, 1999, p.07).

Assim, o modelo biomédico passa a ser questionado não apenas no que diz respeito a sua capacidade de explicar as situações de adoecimento, mas também em suas propostas de ação relacionadas aos aspectos curativos e terapêuticos e às estratégias de intervenção social que preconizava.

Para Almeida Filho (1986), nesse período 
o 'retorno triunfante' do social se faz pelo recurso da Epidemiologia, supostamente despojada da politização [dado seu caráter aparentemente apenas científico e técnico] assumida pelo movimento da Medicina Social presente no século XIX. (p.306).

Outro fator explicativo do retorno da perspectiva social diz respeito ao período após a Segunda Guerra, especialmente a partir da década de 1960, em função da emergência da fase denominada por Susser e Susser (1998) como a Era da Epidemiologia das Doenças Crônicas, em função do relativo e aparente controle de algumas doenças infectocontagiosas e da cada vez maior importância das doenças de natureza crônico-degenerativas nos quadros epidemiológicos.

Para Barata (2005), a partir da década de 1960,

sob a influência das transformações sociais e culturais caracterizadas pela emergência dos movimentos políticos de luta pelos direitos civis, o fortalecimento da perspectiva crítica, a valorização do contexto sociocultural e político na determinação dos comportamentos humanos o interesse pelas explicações sociais do processo saúde-doença passa a ser renovado. (p.10).

No que tange à influência dessas diversas correntes no pensamento médico e na organização dos serviços de saúde no Brasil, Everardo Nunes (1998) afirma que estas são bastante evidentes nos diversos momentos históricos a partir do século XIX, na medida em que "nós também tivemos a nossa Era Social, a Era da Teoria do Germe, a era Pós-Teoria do Germe.” (NUNES, 1998, p.111).

A primeira fase, relacionada às mudanças ocorridas por meio da higiene pública, tem início a partir da imposição de importantes mudanças políticas com a vinda da família real no século XIX, com objetivos relacionados ao conhecimento da colônia como fundamento necessário para a intervenção dirigida ao aumento da produção, defesa da terra e a saúde da população. (NUNES, 1998).

O segundo momento pôde ser percebido no período entre 1914 e 1930 . A partir do contexto da epidemia da "gripe espanhola" (1918) e do ressurgimento da febre amarela, em 1928, a chamada "conjuntura Oswaldo Cruz inaugura a organização da saúde em moldes científicos, com base na bacteriologia e microbiologia e nas ações com respeito à imunização por vacinas" (NUNES, 1998, p.111). Demarca-se, dessa maneira, a organização da saúde publica a partir da perspectiva do contágio e da medicalização, inaugurando nesse período a "Era do germe" no Brasil. (NUNES, 1998). 
O terceiro movimento aconteceu em um contexto da profunda crise econômica pelo qual passaram os países do denominado "terceiro mundo" (especialmente os latinoamericanos) nas décadas de 1970 e 1980, onde se fortaleceram e foram revigoradas as ideias que relacionam as condições de vida com o processo saúde-doença nas populações. Tais ideias serviram de bases para a denominada "Reforma Sanitária", assim como viriam a constituir o arcabouço teórico-metodológico do campo da Saúde Coletiva (NUNES, 2006; BARATA, 2006), demarcando, dessa forma, a nossa era Pós-Teoria do germe. Vale destacar que é nesse contexto que são formuladas a bases constitucionais que definem a saúde como direito de todo o cidadão, assim como os princípios constitutivos do Sistema Único de Saúde no Brasil (BRASIL, 1990).

\subsubsection{A Epidemiologia Social, a Determinação Social e seus modelos explicativos}

Why "social epidemiology"? Is not all epidemiology, after all, "social" epidemiology? In so far as people are simultaneously social and biological organisms, is any biological process ever expressed devoid of social context? - or any social process ever unmediated by the corporal reality of our profoundly generative and mortal bodies? (KRIEGER, 2001, p.693)

Partindo desse questionamento de Nanci Krieger, Barata (2005) aponta que o traço que distingue a Epidemiologia Social das demais correntes do pensamento epidemiológico é "a insistência em investigar explicitamente os determinantes sociais do processo saúdedoença e não apenas a consideração dos aspectos sociais, pois, bem ou mal, todas reconhecem a importância desses aspectos, na explicação do processo saúde-doença." (BARATA, 2005, p.08). Nesse sentido, parte-se do pressuposto de que os aspectos sociais são determinantes na situação de saúde dos indivíduos ou grupos, não podendo ser compreendidos no mesmo conjunto dos demais.

Rouquayrol e Goldbaum (2003) apontam essas diferenças de compreensão do papel atribuído aos fatores de distintas naturezas como condicionantes sociais da doença, considerada em nível coletivo. Afirmam que esses fatores "têm sido tratados a partir de dois pontos de vista que se distinguem exatamente pelo papel atribuído aos componentes 
socioeconômicos, culturais e políticos nesse processo e a História Natural da Doença ${ }^{11}$." (p.22).

Numa primeira abordagem, os fatores socioeconômicos, políticos e culturais são vistos dentro do mesmo conjunto e com a mesma relevância dos fatores naturais, não existindo nenhum tipo de subordinação entre eles. O segundo ponto de vista aponta que os primeiros fatores (aqueles ligados às questões sociais) influenciam de maneira decisiva os segundos (os naturais), ficando esses, portanto, determinados e subordinados aos primeiros (ROUQUAYROL e GOLDBAUM, 2003). Assim, a vertente do pensamento epidemiológico denominada como Epidemiologia Social se distingue das demais ao assumir explicitamente a segunda perspectiva.

A partir do entendimento de que os condicionantes e determinantes sociais são constituintes dos estados de saúde das pessoas e grupos e influenciam de maneira decisiva os demais fatores constituintes do processo saúde-doença, apresentaremos de forma sucinta algumas correntes de pensamento, modelos teóricos e definições de termos-chave para a compreensão dessa perspectiva, com o intuito de demarcar teoricamente o referencial para a análise a que nos propomos.

Para Barata (2005), há atualmente um consenso sobre a importância atribuída aos aspectos sociais historicamente constituídos e seus efeitos na saúde. Por outro lado, a autora aponta que, no tocante aos modelos explicativos acerca do processo saúde-doença "as concordâncias terminam aí” (p.09), pois os diversos modelos atualmente mais utilizados são divergentes em função "da teoria social adjacente, da adoção do conceito de causalidade ou determinação, dos conceitos-chave para a condução das pesquisas e em função do nível de análise dos fenômenos no plano individual ou coletivo.” (BARATA, 2005, p.10).

Kaplan (2004) afirma que os modelos construídos na tentativa de explicar a influência dos aspectos sociais na determinação da situação de saúde têm em comum a análise multinível $^{12}$ ou hierárquica da realidade, a valorização de diferentes processos que interferem

\footnotetext{
${ }^{11}$ História Natural da Doença é o nome dado ao conjunto de processos interativos que compreendem "as interrelações do agente, do suscetível e do meio-ambiente que afetam o processo global e seu desenvolvimento, desde as primeiras forças que criam o estímulo patológico [...] até as alterações que levam a um defeito, invalidez, recuperação ou morte.” (LEAVELL e CLARK, 1976 citados por ROUQUAYROL e GOLDBAUM, 2003, p.20). LEAVEL, H. e CLARK E.G. Medicina Preventiva. São Paulo: McGraw-Hill, 1976.

${ }^{12}$ Krieger (2001, p.695) define a análise multinível na Epidemiologia Social como "referente a um método estatístico, primeiramente desenvolvido nas ciências sociais, que analisa simultaneamente os resultados em relação a determinantes medidos em diferentes níveis (por exemplo, indivíduo, local de trabalho, vizinhança, nacionalidade etc.)."
} 
na saúde e a consideração das influências de uns sobre os outros em uma condição de reciprocidade. Para o autor, esses modelos ou teorias "servem como metáforas importantes na tentativa de retratar os componentes de um processo complexo, suas inter-relações e as relações temporais entre os seus componentes.” (KAPLAN, 2004, p.125).

Dentre as diversas teorias relacionadas à epidemiologia social, Barata (2005) aponta cinco correntes como as que mais influenciam as pesquisas no campo da determinação social do processo saúde-doença hoje em dia. São elas:

A Eco-epidemiologia de Susser e Susser ${ }^{13}$ : procura superar a perspectiva multicausal, pois, para os autores, em função da dificuldade de se estabelecer nexos entre os diversos "fatores de risco" reforça-se o encobrimento das relações entre saúde e sociedade. Tal perspectiva considera que nem todos os determinantes podem ser conceituados como atributos individuais. Para tanto, seu modelo busca articular os componentes presentes em relações de interação recíprocas, respeitando diferentes níveis hierárquicos. Enquanto a perspectiva muticausal, baseada na ideia de risco, formula questões do tipo "o que coloca a pessoa em risco de adquirir a infecção?" a abordagem eco-epidemiológica formularia questões como "o que coloca a população em risco de epidemia? Que características populacionais aumentam sua vulnerabilidade a determinadas epidemias?” (BARATA, 2005, p.11);

A Teoria do Capital Social: fundamentalmente, aponta para a relação entre o nível e as desigualdades de renda e a situação de saúde dos indivíduos, assim como as maneiras pelas quais esses indicadores agem sobre a saúde do indivíduo. Apesar de a relação entre estados de privação e situação de saúde ser bastante conhecida e, de certo modo, inquestionável, muitos autores identificam que em países desenvolvidos (onde, idealmente, as condições de privação não deveriam existir), aspectos como a falta de investimento no capital humano e os efeitos do stress configuram-se como componentes importantes da cadeia de causalidade. Segundo Barata (2005, p.12), para tal perspectiva as questões que se colocam são: "como os fatores sociais influenciam o comportamento, colocando as pessoas em risco?" ou "os fatores psicossociais, tais como o suporte social, estão associados à progressão da doença?”; ou ainda, "como os fatores sociais e comportamentais se relacionam na determinação da doença em indivíduos e na população?”;

13 SUSSER, M. e SUSSER, E. Um futuro para a epidemiologia. In: ALMEIDA FILHO, N. et. AL (orgs.). Teoria epidemiológica hoje: fundamentos, interfaces, tendências. Rio de Janeiro: FIOCRUZ/ABRASCO, 1998. 
A Perspectiva do Curso de Vida: a abordagem de Curso de Vida entende que o estado de saúde de indivíduos ou grupos específicos (coortes) é resultado não apenas das condições atuais, mas sim do conjunto de experiências acumulado ao longo da vida, ou seja, "a trajetória pessoal moldada pelo contexto social e pelas condições materiais de vida" (BARATA, 2005, p.13). Krieger (2001, p.695) aponta que nessa perspectiva (lifecourse perspective) "estão em questão as trajetórias de desenvolvimento das pessoas (tanto biológicas quanto sociais) ao longo do tempo, moldadas pelo período histórico em que vivem e relacionadas ao seu contexto social, econômico, político, tecnológico e ecológico.” Portanto, a situação de saúde das pessoas ou grupos é definida ao longo do tempo, e sua análise deverá levar em consideração não apenas as condições atuais, mas também as circunstâncias vividas anteriormente;

A Produção Social da Doença: tendo origem nos estudos de autores latino-americanos (Asa Cristina Laurell, Jaime Breilh, Juan Samaja ${ }^{14}$, dentre outros), essa perspectiva parte do materialismo histórico e dialético tendo como referencial o conceito de reprodução social, entendida como "o processo pelo qual os determinantes (fatores essenciais) põem limites ou exercem pressão sobre outras dimensões da realidade, sem serem necessariamente determinísticos" (BARATA, 2005, p.13). Nesse sentido, procuram identificar e explicitar os determinantes políticos, econômicos e sociais da distribuição da saúde e da doença e buscam identificar aspectos protetores ou nocivos à saúde presentes na organização social. O conceito de determinação social parte do pressuposto de que a saúde deve ser entendida e analisada a partir das formas de organização da sociedade em seu aspecto macrossocial, tendo como pano de fundo sua estrutura econômica e social, "na medida em que essa dimensão subordina ou subsume as dimensões naturais (atinentes ao ambiente físico e à constituição genética e fisiológica dos indivíduos)." (CEBES, 2009).

A Teoria Ecossocial da distribuição da doença de Nanci Krieger: a teoria ecossocial "procura integrar os raciocínios social e biológico a partir de uma perspectiva histórica e ecológica, buscando desenvolver novos insights sobre os determinantes da distribuição da doença na população e as iniquidades sociais em saúde.” (KRIEGER, 2001, p.694). Tem como conceitos centrais a ideia de "incorporação" (embodiment), ou seja, a maneira como os seres literalmente incorporam, biologicamente, o mundo material e social onde vivem e "as vias de incorporação" (pathways of embodiment), referentes às trajetórias de desenvolvimento

${ }^{14}$ BREILH (1989); BREILH \& GRANDA( 1985); LAURELL, (1987); SAMAJA (2000). 
biológico e social. A autora entende os corpos como artefatos sociais e entidades políticas e procura incluir aspectos presentes em várias teorias com o objetivo de propor uma única explicação que articule os aspectos biológicos, sociais, a história de vida, os efeitos dos contextos ambientais, a reprodução social e a dimensão política (BARATA, 2005). Nessa perspectiva a questão central a ser colocada é: “quem e o que é responsável pelos padrões de saúde, de adoecimento e de bem-estar da população assim como manifestados no presente e no passado?" (KRIEGER, 2001, p. 694).

Ao apresentar os dilemas e desafios atuais da epidemiologia social, Barata (2005) aponta que é fundamental a distinção entre o conceito de causa e o de determinação social. Na medida em que estão na base das explicações sobre os processos de adoecimento, a diferenciação entre esses conceitos é fundamental para a compreensão das implicações decorrentes da adoção de um ou de outro, pois, dentre outros fatores, determinam a perspectiva das ações voltadas à prevenção, inclusive no que diz respeito aos aspectos educacionais constituintes dessas ações.

O primeiro conceito (causa), cuja origem pode ser encontrada nos estudos fisiopatológicos, tanto na perspectiva uni como multicausal, necessita da identificação e isolamento de um (ou vários) eventos independentes que devem estar "relacionados através de uma ligação unidirecional, necessária, específica e capaz de gerar o desfecho de interesse." (BARATA, 2005, p.14). Barata entende que tal conceito é insuficiente e inadequado para a compreensão de aspectos relacionados à vida social, pois, dada sua complexidade, os fatores inerentes à questão, quando dissociados, tratados de maneira independente e isolados do contexto de sua produção perdem o sentido e o significado.

Segundo a mesma autora, o conceito de determinação, por sua vez, se mostra mais adequado à compreensão de processos sociais complexos, na medida em que "não necessita do isolamento completo das variáveis, nem da noção de independência entre elas." (BARATA, 2005, p.14). Além disso, não está baseado na ideia de um vínculo necessário e específico entre o fator e o desfecho de interesse. Ou seja, "a maioria das relações entre os determinantes e os desfechos não podem ser entendidas como contingentes, ou seja, não são nem necessárias nem suficientes em si mesmas.” (BARATA, 2005, p.15).

Assim, o que diferencia as ideias de causa e de determinação é a necessidade de isolar e considerar os aspectos a serem analisados como variáveis independentes no primeiro caso, e a clareza dos limites de cada um dos aspectos da vida social para a explicação da situação de saúde dos indivíduos ou grupo, no segundo. 
Como exemplo do reconhecimento da importância dos determinantes sociais para a saúde, a Organização Mundial da Saúde (OMS) e, posteriormente, o Ministério da Saúde brasileiro (MS), recentemente criaram comissões (Commision on Social Determinants of Health e Comissão Nacional Sobre Determinantes Sociais da Saúde, respectivamente) a fim de investigar as relações existentes entre desigualdades sociais e situações de saúde, assim como propor estratégias de intervenção com vistas à melhoria das condições de saúde da população. A justificativa, em ambos os casos, está baseada na constatação da crescente desigualdade entre países, blocos de países e regiões dentro de um mesmo país no tocante às condições de saúde e acesso aos bens e serviços, além do consenso acerca da profunda relação existente entre as condições de vida e a situação de saúde dos indivíduos.

A comissão da Organização Mundial da Saúde define os determinantes sociais da saúde (DSS) como

as condições em que as pessoas nascem, crescem, vivem, trabalham e envelhecem, incluindo o sistema de saúde. Estas circunstâncias são formadas pela distribuição do dinheiro, poder e recursos a nível global, nacional e local, os quais são influenciados por decisões políticas. Os determinantes sociais da saúde são os principais responsáveis pelas desigualdades na saúde, ou seja, as diferenças injustas e evitáveis no estado de saúde visto dentro e entre países. (WHO, 2008).

Por sua vez, a Comissão Nacional sobre Determinantes Sociais da Saúde (CNDSS) os apresenta como

as condições mais gerais socioeconômicas, culturais e ambientais de uma sociedade, relacionadas com as condições de vida e trabalho de seus membros, como habitação, saneamento, ambiente de trabalho, serviços de saúde e educação, incluindo também a trama de redes sociais e comunitárias. (BRASIL, 2008, p.13).

Vale ressaltar que dentre os muitos produtos e processos desencadeados por essas comissões foi realizada recentemente no Rio de Janeiro, sob a coordenação da OMS, a Conferência Mundial Sobre os Determinantes Sociais da Saúde (World Conference on Social Determinants of Health), cujo principal objetivo foi propor ações e políticas com vistas à diminuição das iniquidades em saúde. Neste evento, representantes 125 países assinaram um documento intitulado Rio Political Declaration on Social Determinants of Health (WHO, 2011), firmando o compromisso das Nações Unidas e dos diversos países em enfrentar conjuntamente os fatores sociais que geram essas iniquidades. No documento, os signatários apontam que 
as desigualdades na saúde surgem das condições sociais em que as pessoas nascem, crescem, vivem, trabalham e envelhecem, [e são] referidas como determinantes sociais da saúde. Estes incluem as experiências dos primeiros anos de vida, a educação, o status econômico, emprego e trabalho digno, habitação e meio ambiente, e sistemas eficazes de prevenção e tratamento da doença (WHO, 2011),

reafirmando assim o papel dos determinantes sociais como estruturantes da situação de saúde dos indivíduos e grupos populacionais, assim como das iniquidades em saúde decorrentes das desigualdades sociais existentes entre eles.

Para Buss e Pellegrini Filho (2007), as várias definições sobre os determinantes sociais da saúde formuladas atualmente "expressam com maior ou menor nível de detalhe, o conceito atualmente bastante generalizado de que as condições de vida e trabalho dos indivíduos e de grupos da população estão relacionadas com sua situação de saúde.” (BUSS e PELLEGRINI FILHO, 2007, p.78).

Como referencia teórica, ambas as comissões adotaram o modelo proposto por Dahlgren e Whitehead (2001) (figura 1) que, para muitos autores reflete novamente uma visão fragmentada e positivista da determinação social. Para esses críticos, ao analisar as situações de saúde dos grupos e, principalmente, ao sugerir encaminhamentos para o enfrentamento das situações adversas à saúde propondo para sua análise a separação e o isolamento de fatores como variáveis independentes, o modelo adotado retorna a uma perspectiva de causa-efeito, tida como insuficiente e inadequada, em função das questões postas em jogo. (NAVARRO, 2009; GARRAFA e CORDÓN, 2009; NOGUEIRA, 2009).

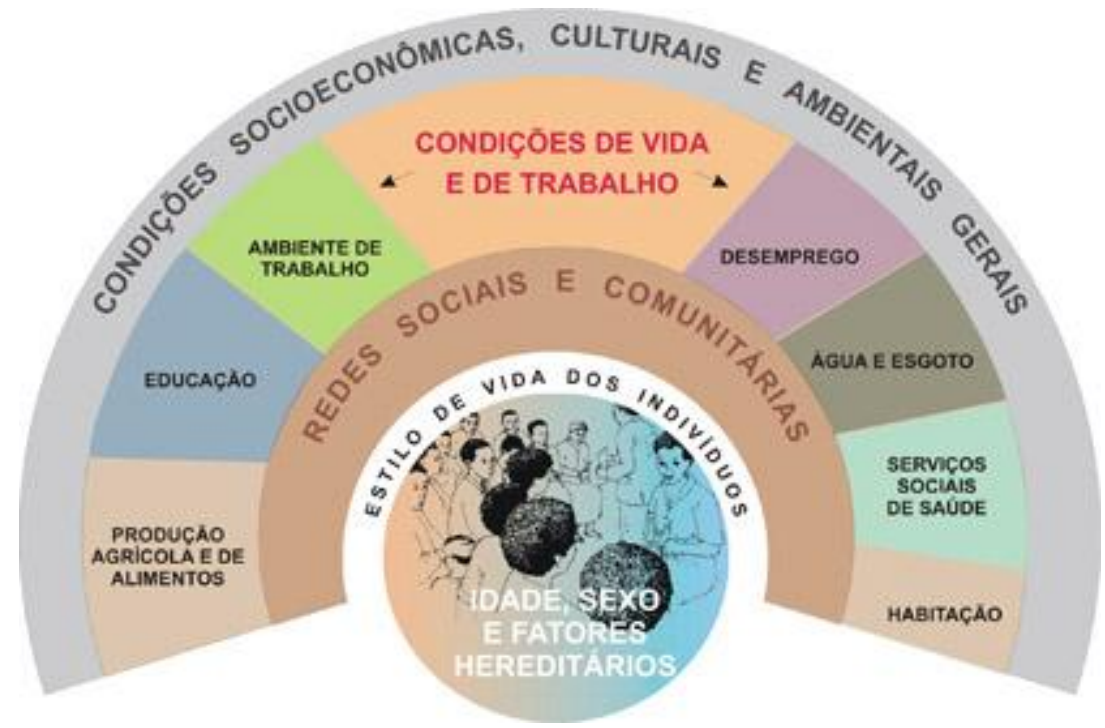

Figura 1: Modelo de determinação social da doença proposto por Dahlgren e Whitehead (1991) Fonte: Relatório Final da Comissão Nacional sobre Determinantes Sociais da Saúde (BRASIL, 2008). 
Vicente Navarro (2009) ao questionar "what we mean about Social Determinants of Health?" tece uma forte crítica sobre a postura pretensamente apolítica da OMS presente no relatório elaborado por sua comissão, afirmando que "não são as iniquidades em saúde que matam as pessoas, assim como dito no relatório, mas sim quem se beneficia dessas iniquidades." (NAVARRO, 2009, p.438). Afirma também que "a não utilização, por parte dos estudiosos da comissão, da categoria poder (poder e classe, gênero, raça, poder nacional etc.) e como o poder é produzido e reproduzido nas instituições políticas é a grande fraqueza do relatório". (NAVARRO, 2009, p.440).

Barata (2006) relaciona esse recente interesse pela perspectiva social da doença ao processo de globalização e ao crescente aumento das desigualdades sociais entre os países ao afirmar que

o interesse no estudo das relações entre a situação socioeconômica e saúde tem ressurgido nos países desenvolvidos [...]. Vários autores atribuem esse interesse renovado às consequências deletérias que o processo de globalização teve sobre as condições de vida e a situação de saúde dos povos ocidentais. (BARATA, 2006, p.458).

Tais consequências estão fundamentalmente ligadas às profundas desigualdades de acesso aos bens e serviços, cada vez maiores entre os países e dentro de um mesmo país, que acabam por gerar aspectos de iniquidade, ou seja, de injustiça social. (BARATA, 2006).

Nesse mesmo sentido, Nogueira (2009) aponta que são dois aspectos, um de ordem ideológica e outro político-econômico do cenário mundial nos dias de hoje, que explicam a atual preocupação da OMS em formar uma comissão e produzir diretrizes para o enfrentamento dos determinantes sociais que influenciam na saúde.

No campo ideológico, o aspecto destacado pelo autor diz respeito à ascensão de um ideário "pós-neoliberal" fomentado pelas agências internacionais, quando "ultrapassada a fase de ênfase absoluta na contenção do gasto e no arrocho fiscal do 'estado mínimo', políticas típicas dos anos 1980 e 1990, as agências puderam reconhecer um sentido mais amplo da proteção social a ser adotada pelos países.” (NOGUEIRA, 2009, p. 399).

Quanto ao contexto político-econômico, o autor aponta a tendência de formação de blocos de países ou comunidades e a exclusão de uma importante parcela da população dos mercados que vêm sendo reestruturados como fator contextual na medida em que 
dimensão ética, trata-se da impossibilidade de que certos grupos sociais participem plenamente do novo mercado integrado que está emergindo. E o mercado de bens e serviços da saúde é cada vez mais relevante para a acumulação capitalista. (NOGUEIRA, 2009 p. 399).

Mesmo não sendo objeto desse trabalho e sem a pretensão de realizar uma análise das conjunturas políticas e socioeconômicas que definem e influenciam o pensamento em saúde, pode-se dizer, sinteticamente, que a retomada da preocupação com os fatores sociais que influenciam a saúde da população, principalmente das camadas mais empobrecidas se dá, novamente em um momento no qual a situação de saúde desses grupos interfere nos interesses de acumulação do capital.

Como já discutido, esse movimento tem sua origem no momento de consolidação do capitalismo e a preocupação com a saúde da mão de obra trabalhadora (século XIX). Posteriormente, essa perspectiva foi retomada no período posterior à crise de 1929 e a impossibilidade dos países de fornecer condições mínimas de saúde à população e aos trabalhadores, considerados como mão de obra necessária à produção fabril e à acumulação de capital. Num período seguinte, o contexto de profunda crise econômica pelo qual passaram os países do denominado "terceiro mundo" nas décadas de 1970 e 1980 e a incapacidade de prover serviços mínimos de assistência à saúde por parte desses países suscitou o ressurgimento dessa preocupação. Atualmente a relação entre os determinantes sociais e a situação de saúde reaparece em um momento de consolidação dos blocos econômicos e comunidade de países, a exclusão de significativa parcela da população dos mercados consumidores e a consequente reestruturação desses mercados.

Dentro do quadro conceitual da determinação social da saúde (ou da doença) emerge na segunda metade do século XX a ideia e o movimento denominado como Promoção da Saúde. Tal ideia é utilizada atualmente como pressuposto para as mais variadas estratégias de intervenção social, com os mais variados objetivos, tendo a dimensão educacional como um de seus pilares de ação. Nesse sentido, entendemos ser importante delimitar esse conceito, apresentar seus limites, as críticas feitas a essa proposta, assim como diferenciá-lo do que comumente é denominado como "prevenção" em saúde. 


\title{
2.2.7. A Promoção da Saúde: retomada de uma ideia, histórico de construção do conceito e sua crítica.
}

\author{
O discurso da Promoção da Saúde não é homogêneo e \\ apresenta contradições que correspondem a interesses \\ divergentes [...] e contemplam perspectivas das mais \\ conservadoras às mais progressistas. (CZERESNIA e \\ FREITAS, 2009, p.11).
}

A Organização Mundial da Saúde define atualmente o termo Promoção da Saúde como

o processo de capacitar as pessoas para aumentar o controle sobre e para melhorar a sua saúde. Ela se estende para além de um foco no comportamento individual, no sentido de uma ampla gama de intervenções sociais e ambientais. (WHO, 2010)

Segundo a própria OMS, a partir do reconhecimento da "necessidade de mudanças nos meios e condições de vida das pessoas para que sua saúde seja promovida" (WHO, 2009, p. 03), esse conceito se ancora na ideia de que a situação de saúde está intrinsecamente relacionada às condições de vida e que para melhorá-la não bastam ações de assistência e tampouco implementadas apenas pelo "setor saúde". Nesse sentido, as ações que procuram desenvolver estratégias voltadas à promoção da saúde e os estudos acerca do tema definem como um dos seus princípios o caráter necessariamente intersetorial das ações, nas quais as atividades de natureza educativa (seja na escola ou fora dela) assumem lugar de destaque.

A ideia de promoção da saúde retoma, portanto, a perspectiva que relaciona as condições de vida às situações de saúde. Não sendo nova, "resgata, com um novo discurso, o pensamento médico social do século XIX expresso nas obras de autores como Virchow, Villermé, Chadwick e outros.” (CZERESNIA, 2009, p.43).

Segundo Buss (2007), quem primeiro utilizou o termo foi Winslow (1920) ao afirmar que "a promoção da saúde é um esforço da comunidade organizada para alcançar políticas que melhorem as condições de saúde da população e os programas educativos para que o indivíduo melhore sua saúde pessoal.” (WINSLOW, 1920, p.23 citado por BUSS, 2009, p.21), relacionando o termo promoção da saúde à própria ideia de saúde pública da seguinte forma: 
Public health is the science and the art of preventing disease, prolonging life, and promoting physical health and efficiency through organized community efforts for the sanitation of the environment, the control of community infections, the education of the individual in principles of personal hygiene, the organization of medical and nursing service for the early diagnosis and preventive treatment of disease, and the development of the social machinery which will ensure to every individual in the community a standard of living adequate for the maintenance of health. (WINSLOW, 1920, p.30)

Depois disso, Sigerist (1946) ${ }^{15}$ definiu que as quatro tarefas essenciais da medicina são: a promoção da saúde, a prevenção de doenças, a recuperação e a reabilitação e que "a saúde se promove proporcionando condições de vida decentes, boas condições de trabalho, educação, cultura física e formas de lazer e descanso." (SIGERIST, 1946, p.19 citado por BUSS, 2009, p.21). Em Leavell e Clark, quando da proposição do modelo da História Natural da Doença, a promoção da saúde aparece como um dos componentes da prevenção primária no nível pré-patogênico (BUSS, 2007; CZERESNIA, 2007; WESTPHAL, 2006), articulando a ideia de promoção como uma das estratégias de prevenção.

A partir da década de 1970, essa perspectiva ganha força nos países desenvolvidos (originando-se no Canadá) em reação à crescente medicalização da sociedade e a cada vez maior incorporação por parte dos sistemas de saúde de uma assistência médica curativa de alta tecnologia, que passou a gerar um maior gasto dos sistemas de saúde, sobrecarregando-os e sem que os resultados esperados fossem alcançados. (BUSS, 2009; CZERESNIA, 2009).

Em função dessa situação, é proposto um novo enfoque na relação saúde-enfermidadecuidado, principalmente a partir do trabalho intitulado "Uma nova perspectiva na saúde dos canadenses" (ou o "Relatório Lalonde" ${ }^{16}$ ), no qual Marc Lalonde, na época ministro da saúde e do bem-estar no Canadá, propõe a ideia de "campo da saúde", decompondo-o em quatro grandes componentes: "a biologia humana, o meio ambiente, os estilos de vida e a organização da atenção à saúde.” (LALONDE, 1996). Tal documento, a despeito das críticas sofridas, é considerado um marco inicial para a constituição do pensamento teórico do movimento da promoção da saúde.

É a partir do que se convencionou chamar nova saúde pública (NSP), tendo como pano de fundo o cenário de implementação das políticas neoliberais de estado mínimo nas

\footnotetext{
${ }^{15}$ SIGERIST, H. The social sciences in the medical school. In: SIGERIST, H. (org.).The University at the Crossroad. New York: Henry Schumman Publisher, 1946.

${ }^{16} \mathrm{O}$ "Relatório Lalonde" foi primeiramente publicado como: A new perspective on the health of Canadians: a working Document. Ottawa: Canadian Information, 1974.
} 
décadas de 1980 e 1990, que o discurso da promoção da saúde procura desonerar o estado, seja no que diz respeito aos gastos, seja de responsabilidade sobre a saúde dos indivíduos e da população. (CZERESNIA, 2009; CASTIEL, 2007).

A constituição do "movimento da promoção da saúde" foi marcada, ao longo dos anos, por diversas conferências mundiais, nas quais seus marcos conceituais foram sendo construídos (BRASIL, 2002; WESTPHAL, 2006; BUSS, 2007; WHO, 2009). Nesse movimento, destaca-se a Conferência de Ottawa (First International Conference on Health Promotion, Ottawa, CA - 1986), onde foram definidos cinco campos de ação da promoção da saúde: 1) a elaboração e implementação de políticas públicas saudáveis; 2) a criação de ambientes favoráveis à saúde; 3) o reforço da ação comunitária; 4) o desenvolvimento de habilidades pessoais e 5) a reorientação do sistema de saúde. (WHO, 2009, BUSS, 2007).

No que diz respeito especificamente à América Latina, é também considerado como documento de referência para a promoção da saúde a Declaração de Bogotá (1992) que relaciona as ações de promoção da saúde com aquelas que buscam transformações mais profundas na ordem social. Dado o contexto socioeconômico da região, tal documento afirma que a promoção da saúde na América Latina não pode ser descontextualizada da necessidade de mudanças em "uma realidade profundamente desigual, que resulta na deterioração das condições de saúde, no aumento dos riscos à saúde e na redução dos recursos para enfrentar os problemas daí derivados." (FREITAS, 2009).

$\mathrm{Na}$ medida em que o discurso da promoção da saúde foi sendo estabelecido e formalizado a partir da ideia de autonomia do sujeito frente às decisões que afetam sua saúde (CZERESNIA, 2009; CASTIEL, 2007), uma forte crítica é feita em relação à ideia de "estilos de vida" e a perigosa tendência de culpabilização dos sujeitos frente as suas escolhas, consideradas como saudáveis ou não.

Castiel (2007) aponta dois problemas quanto à relação entre os "estilos de vida" e as situações de saúde. O primeiro "seria a 'moralização' dos comportamentos arriscados e dos correspondentes estilos de vida 'desregrados' [...], que pode veicular conotações ligadas ao terreno do 'pecado' ou da 'fraqueza de caráter"' (p.82). O segundo problema se relaciona à culpabilização do sujeito e sua consequente dimensão apenas individual onde "o foco [está] voltado para o controle comportamental individual [e] não enfatiza a busca de transformações de aspectos macrossociais que estimulam condutas chamadas de risco." (CASTIEL, 2007, p.83). 
Outra crítica sua bastante contundente diz respeito à própria ideia de escolha, especialmente em contextos onde as condições de vida e de acesso aos bens de consumo não permitem que essas sejam feitas.

Sem duvidas, uma crítica comum ao conceito de estilo de vida é referente a seu emprego em contextos de miséria e aplicado a grupos sociais em que as margens de escolha praticamente inexistem. Muitas pessoas não escolhem o estilo da vida que levam. Na verdade, não há opções disponíveis, apenas estratégias possíveis de sobrevivência. (CASTIEL, 2009, p.87).

O mesmo autor, na sua bastante clara afirmação, aponta que "existem casos em que, por motivos de privação econômica e exclusão social, não há possibilidade de escolha. Nessas situações, não faz sentido considerar as pessoas responsáveis por seus 'estilos de vida'." (CASTIEL, 2007, p.85). Ou seja, por mais óbvio que possa parecer, não há escolhas onde essas não são possíveis. Assim, nestes contextos a ideia de estilos de vida ou as orientações voltadas à modificação destes "estilos" perdem totalmente o sentido.

Por não haver um discurso hegemônico sobre a promoção da saúde, podem ser percebidas atualmente duas vertentes nesse campo, definidas como de tendência conservadora ou progressista. (CASTIEL, 2007; CZERESNIA, 2009). A primeira distinção entre elas se dá em função da perspectiva da ação ser individual ou coletiva. $O$ segundo aspecto de diferenciação está relacionado ao maior ou menor grau de responsabilização do Estado, por meio dos sistemas de saúde, mas não somente deles, quanto à situação de saúde da população.

A primeira perspectiva (conservadora) reforça a tendência de desresponsabilização do Estado "delegando, progressivamente, aos sujeitos, a tarefa de tomarem conta de si mesmos" (CZERESNIA, 2009, p.44), como "um meio de direcionar os indivíduos a assumirem a responsabilidade por sua saúde e, ao fazerem, reduzirem o peso financeiro da assistência à saúde." (CASTIEL, 2007, p.75). Nessa perspectiva, o foco é exclusivamente individual e as ações de promoção de saúde se restringem às atividades direcionadas para a mudança dos comportamentos dos indivíduos e seus estilos de vida considerados como "não saudáveis", com programas relacionados à riscos que estariam (mesmo que parcialmente) sob o controle dos próprios indivíduos. Nessa perspectiva, todos os outros fatores que estiverem fora desse (relativo) controle por parte do indivíduo, não fazem parte do foco dessas ações (BUSS, 2000), o que afirma e reforça o seu caráter conservador.

A segunda perspectiva, de caráter progressista, parte da necessidade da proposição de ações intersetoriais voltadas à melhoria das condições de vida das pessoas, "como estratégias para criar mudanças na relação entre cidadãos e o Estado", podendo constituir-se "em uma 
perspectiva libertária que busca mudanças sociais mais profundas." (CASTIEL, 2007, p. 75). O caráter intersetorial dessas ações é visto como fundamental, na medida em que as ações desencadeadas por um único setor da administração pública (saúde, educação, habitação, saneamento etc.) não são suficientes para desencadear tais mudanças nas condições de vida da população.

Nessa vertente, a promoção da saúde

alcança uma abrangência muito maior do que a que circunscreve o campo específico da saúde, incluindo o ambiente em sentido amplo, atravessando a perspectiva local e global, além de incorporar elementos físicos, psicológicos e sociais. (CZERESNIA, 2009, p.44).

Além disso, nessa perspectiva,

que não nega a primeira, mas a amplia, à promoção não caberia apenas possibilitar o desenvolvimento de habilidades individuais e comunitárias, mas também a intervenção ambiental por intermédio de um amplo conjunto de meios políticos, legislativos, fiscais e administrativos [...]. Nessa conceituação, a promoção da saúde estaria mais voltada para o coletivo de indivíduos e o ambiente em uma perspectiva ampla, incluindo o físico, o social, o político, o econômico e o cultural. (FREITAS, 2009, p.153).

A partir dessas críticas, o conceito de promoção da saúde se modificou ao longo das últimas décadas, no sentido de associar-se não mais às possibilidades de escolhas individuais, mas à elaboração e implementação de políticas públicas com vistas à modificação das condições de vida deletérias à saúde dos indivíduos e comunidades. Essas ações são entendidas como

políticas caracterizadas pela explícita preocupação com a saúde e a equidade em todas as áreas e por uma responsabilização conjunta pelos impactos na saúde, e têm por objetivo principal criar um ambiente favorável para que as pessoas levem uma vida saudável. (NUTBEAN, 1998, p.359).

Mesmo insistindo na ideia de estilos de vida, que traz necessariamente o foco para o indivíduo, esse "deslocamento" em direção a uma perspectiva mais progressista passou a ser expresso nos documentos da OMS já em 1998, quando a Organização sinaliza que

se a saúde deve ser aperfeiçoada ao capacitar indivíduos a modificar seus estilos de vida, a ação precisa ser dirigida não apenas ao indivíduo, mas também às condições sociais e de vida que interagem para produzir e manter estes padrões de comportamento. (WHO, 1998, p.16)

No documento norteador da Política Nacional de Promoção da Saúde (BRASIL, 2006) é explicitada a preocupação central voltada não mais ao campo da mudança de hábitos 
ou "estilos de vida". Fica clara, na introdução desse documento, a perspectiva de uma ação política que extrapola as ações de saúde e do próprio setor saúde da administração pública, ao afirmar que

a promoção da saúde é uma estratégia de articulação transversal, na qual se confere visibilidade aos fatores que colocam a saúde da população em risco e às diferenças entre necessidades, territórios e culturas presentes no nosso País, visando à criação de mecanismos que reduzam as situações de vulnerabilidade, defendam radicalmente a equidade e incorporem a participação e o controle sociais na gestão das políticas públicas. (BRASIL, 2006a, p.14).

O mesmo documento propõe como objetivo geral dessa política

promover a qualidade de vida e reduzir vulnerabilidade e riscos à saúde relacionados aos seus determinantes e condicionantes - modos de viver, condições de trabalho, habitação, ambiente, educação, lazer, cultura, acesso a bens e serviços essenciais. (BRASIL, 2006a, p.19).

A partir desse entendimento, Buss (2009, p. 36) afirma que são cinco prioridades para o campo da promoção da saúde:

$1^{\circ}$. Promover a responsabilidade social em saúde, com a ênfase na criação de "políticas públicas saudáveis"17 e com a articulação com o setor privado;

$2^{\circ}$. Aumentar os investimentos no desenvolvimento da saúde, a partir do enfoque intersetorial, reafirmando a reorientação de investimento em políticas para a saúde, educação, habitação etc. a fim de fomentar o desenvolvimento humano;

$3^{\circ}$. Consolidar e expandir as parcerias entre os diferentes níveis e setores do governo;

$4^{\circ}$. Aumentar a capacidade da comunidade para lidar com as questões relativas às suas condições de vida e fortalecer os indivíduos na busca de melhorias das condições de saúde;

$5^{\circ}$. Assegurar uma infraestrutura para a promoção da saúde, a partir da definição de espaços para ações dessa ordem, da criação de redes de promoção da saúde;

${ }^{17}$ O termo "Políticas Públicas Saudáveis" aparece como um dos princípios da promoção da saúde na Carta de Ottawa (OMS, 1986). Diz respeito à "necessidade de inserção na agenda de prioridades dos políticos e dirigentes em todos os níveis e setores, chamando-lhes a atenção para as consequências que suas decisões podem ocasionar no campo da saúde e a aceitarem suas responsabilidades políticas com a saúde." (BRASIL, 2002, p.20). As políticas públicas saudáveis "se materializam através de diversos mecanismos complementares, que incluem legislação, medidas fiscais, taxações e mudanças organizacionais [...] e por ações intersetoriais coordenadas que apontem para a equidade em saúde, distribuição mais equitativa da renda e políticas sociais.” (BUSS, 2000, p.168). 
da documentação de experiências (pesquisas e avaliações) e maior aporte de recursos financeiros e materiais.

Tendo como um de seus princípios o fortalecimento comunitário de caráter coletivo e a participação popular, o termo empowerment (empoderamento), é considerado um dos conceitos-chave no campo da proporção da saúde e definido pela OMS como "o processo através do qual as pessoas ganham maior controle sobre as decisões e ações que afetam a sua saúde." (WHO, 1998, p. 60). A OMS faz uma distinção entre o empoderamento individual e coletivo. Enquanto o primeiro se refere à capacidade dos indivíduos para tomar decisões e ter controle sobre sua vida pessoal, o segundo diz respeito "à capacidade de agir coletivamente para conseguir maior influência e controle sobre os determinantes da saúde e da qualidade de vida em sua comunidade, sendo uma meta importante na ação comunitária para a saúde." (WHO, 1998, p. 61).

Portanto, a ideia de promoção da saúde percorreu uma trajetória que, nos primeiros anos, tinha como objetivo central a modificação dos estilos de vida (tendo a denominada “educação em saúde" um papel preponderante) para, mais recentemente, assumir a função de articular ações de diversos setores do Estado e da sociedade, a fim de modificar as condições desfavoráveis à saúde. Nessa perspectiva preconiza como uma de suas principais estratégias o fortalecimento das comunidades, especialmente, mas não só, em contextos de desigualdades sociais.

Nesse sentido, ao incorporar a ideia de promoção da saúde, desloca-se também dos objetivos específicos do setor saúde (ou da esfera de assistência à saúde), de ações de caráter assistencial ou de atendimento, para ações natureza muito mais ampla, voltadas à melhoria da qualidade de vida.

Além disso, vislumbra-se uma mudança em relação ao papel que a educação pode desempenhar para a melhoria das condições de saúde, na medida em que a "educação em saúde" deixa de ser apenas o veículo de transmissão de informações sobre as doenças, sobre e medidas para preveni-las ou sobre atitudes e hábitos "saudáveis", para constituir-se com um meio para a compreensão e problematização da realidade no que diz respeito aos aspectos que interferem no estado de saúde, tanto nível do indivíduo quanto coletivo, assim como para possibilitar condições para a atuação social com vistas a transformar as condições desfavoráveis à saúde. 


\subsubsection{Promoção da Saúde e Prevenção de Doenças: diferenças}

É bastante comum o discurso acerca das diferenças entre os termos promoção de saúde e prevenção de doenças colocando-os em posições opostas, muitas vezes associando o primeiro a uma visão "avançada" ou "moderna" e o segundo a uma perspectiva "ultrapassada" ou mesmo "anacrônica" para o enfrentamento das questões relativas à saúde pública. Para Buss (2009), essas duas perspectivas devem ser vistas como enfoques complementares relacionados ao processo saúde-doença, tanto no nível individual quanto coletivo. Para o autor, a linha divisória entre esses dois termos é bastante tênue e "com frequência, o conteúdo teórico entre esses dois enfoques se diferencia com mais precisão do que as respectivas práticas.” (BUSS, 2009, p.37).

Czeresnia (2009, p.49) ao discorrer acerca dessas diferenças, recorre à etimologia ao apontar que o termo prevenir "significa chegar antes de; dispor de maneira que evite (dano, mal); impedir que se realize" e, citando Leavell e Clark $\left(1976\right.$, p. 17) ${ }^{18}$, afirma que as ações de prevenção exigem "uma ação antecipada, baseada no conhecimento da história natural [da doença] a fim de tornar improvável o progresso posterior da doença". Nesse sentido, as ações de prevenção

definem-se como intervenções orientadas a evitar o surgimento de doenças específicas, reduzindo sua incidência e prevalência nas populações [...]. Seu objetivo é o controle da transmissão de doenças infecciosas e a redução do risco de doenças degenerativas ou outros agravos específicos. (CZERESNIA, 2009, p.49)

Assim, as ações dessa natureza

estão mais voltadas à detecção, controle e enfraquecimento dos fatores de risco ou fatores causais de grupos de enfermidades ou de uma enfermidade específica; seu foco é a doença e os mecanismos para atacá-la mediante o impacto sobre os fatores mais íntimos que a geram ou precipitam. [...]. O objetivo final é o de evitar a enfermidade. (BUSS, 2009, p.37).

Dentro dessa perspectiva, as ações educacionais que têm como foco a prevenção de doenças "estruturam-se mediante a divulgação de informação científica [sobre a doença e os riscos] e de recomendações normativas de mudanças de hábitos." (CZERESNIA, 2009, p.49). Portanto, a partir dessa perspectiva, estabelece-se um determinado papel para a educação no que diz respeito à saúde, relacionado ao conhecimento da doença (seus sinais e sintomas),

\footnotetext{
${ }^{18}$ LEAVELL, S \& CLARK, E. G. Medicina preventiva. São Paulo: McGraw-Hill, 1976.
} 
seus agentes etiológicos ou de risco e medidas de prevenção voltadas, em sua maioria, a aspectos ligados aos comportamentos individuais ou aos hábitos.

O termo promoção de saúde, segundo a mesma análise etimológica, "tem o significado de dar impulso a; fomentar; originar; gerar". Assim, as ações de promoção "não se dirigem a uma determinada doença ou desordem, mas servem para aumentar a saúde e o bem-estar gerais." (CZERESNIA, 2009, p.49).

Na medida em que não são focadas em uma doença ou agravo específico, as ações de promoção da saúde têm um caráter bem mais amplo em relação às ações de prevenção. Partem do pressuposto de que a ausência de doença não é suficiente, na medida em que frente a qualquer nível de saúde de um indivíduo sempre haverá algo a ser feito para promover um melhor nível de saúde e melhores condições de vida. (GUTIERREZ et. al., 1997).

A partir de Stachtchenko e Jenicek (1990), Buss (2009) sintetiza, no seguinte esquema, algumas categorias de diferenciação entre promoção da saúde e prevenção de doenças. (figura 2).

\begin{tabular}{|l|l|l|}
\hline \multicolumn{1}{|c|}{ Categorias } & \multicolumn{1}{|c|}{ Promoção da Saúde } & \multicolumn{1}{c|}{ Prevenção de Doenças } \\
\hline Conceito de Saúde & Positivo e multidimensional & Ausência de Doença \\
\hline $\begin{array}{l}\text { Modelo de } \\
\text { Intervenção }\end{array}$ & Participativo & Médico \\
\hline Alvo & Toda a população, no seu ambiente total & $\begin{array}{l}\text { Principalmente os grupos de } \\
\text { alto risco da população }\end{array}$ \\
\hline Estratégias & Diversas e complementares & Geralmente única \\
\hline Abordagens & Facilitação e capacitação & Direcionadoras e persuasivas \\
\hline $\begin{array}{l}\text { Direcionamento das } \\
\text { Medidas }\end{array}$ & Oferecidas à população no geral & Impostas a grupos-alvo \\
\hline $\begin{array}{l}\text { Objetivos dos } \\
\text { Programas }\end{array}$ & $\begin{array}{l}\text { Mudanças na situação dos indivíduos e de seu } \\
\text { ambiente }\end{array}$ & $\begin{array}{l}\text { Focam principalmente em } \\
\text { indivíduos e grupos de } \\
\text { pessoas }\end{array}$ \\
\hline $\begin{array}{l}\text { Executores dos } \\
\text { programas }\end{array}$ & $\begin{array}{l}\text { Organizações não-profissionais, movimentos } \\
\text { sociais, governos locais, municipais, regionais } \\
\text { e nacionais etc. }\end{array}$ & Profissionais da saúde \\
\hline
\end{tabular}

Figura 2: quadro comparativo entre promoção da saúde e prevenção de doenças adaptados de Stachtchenko e Jenicek (1990) em BUSS, P. M. (2009, p. 39).

A despeito de ser uma referência importante nos trabalhos que tratam da diferenciação entre promoção e prevenção (AYRES, 2007; BUSS, 2009; CZERESNIA, 2009; WESTPHAL, 2006) a proposta de Stachtchenko e Janieck, dado seu caráter esquemático e, principalmente, por apresentar o conceito de saúde de maneira dicotômica em relação à 
doença, sofre algumas críticas. Ayres (2007), ao problematizar essa polarização, aponta "a clássica distinção de Stachtchenko e Janicek" trata de maneira polarizada o conceito de saúde nessas duas perspectivas e que

esse tipo de polarização obscurece o fato de que a ausência ou redução de doença é, efetivamente, um dos indicadores que usamos para avaliar se estamos conseguindo promover a saúde. Por outro lado, se não houvesse uma referência positiva, algum tipo de valorização, sempre multidimensional, que nos orientasse sobre o que positivamente desejamos em relação aos nossos modos de andar a vida, não teríamos a concepção fisiopatológica da doença [...]. Essa polarização obscurece, portanto, que há uma dimensão positiva de saúde por trás do conceito negativo de doença. (AYRES, 2007, p.46).

Westphal (2006) propõe outra possibilidade de análise das ações voltadas à promoção da saúde, assim como das diferenças existentes entre promoção e prevenção, a partir de sua relação com o que denomina de "concepções de saúde" que, segundo a autora, determinam distintas abordagens no que tange às propostas de ação: biomédica, comportamental e socioambiental. A autora sugere que ações pautadas em abordagens definidas como "biomédica" e "comportamental" estão mais relacionadas à prevenção de doenças, "vinculadas a uma visão biologicista e comportamentalista do processo saúde-doença", enquanto que as ancoradas na perspectiva "socioambiental" dizem respeito ao entendimento atual sobre promoção da saúde e são "mais vinculadas a uma visão holística desse processo." (WESTPHAL, 2006, p. 647). (figura 3).

\begin{tabular}{|l|l|l|l|}
\hline Abordagens & \multicolumn{1}{|c|}{ Biomédica } & \multicolumn{1}{c|}{ Comportamental } & \multicolumn{1}{c|}{ Socioambiental } \\
\hline $\begin{array}{l}\text { Conceito de } \\
\text { saúde }\end{array}$ & $\begin{array}{l}\text { Ausência de } \\
\text { doenças e } \\
\text { incapacidades }\end{array}$ & $\begin{array}{l}\text { Capacidades físico- } \\
\text { funcionais; bem-estar } \\
\text { físico e mental dos } \\
\text { indivíduos }\end{array}$ & $\begin{array}{l}\text { Estado positivo; bem estar } \\
\text { biopsicossocial e espiritual; } \\
\text { realização de aspirações e } \\
\text { atendimento de necessidades }\end{array}$ \\
\hline $\begin{array}{l}\text { Determinantes } \\
\text { de saúde }\end{array}$ & $\begin{array}{l}\text { Condições } \\
\text { biológicas e } \\
\text { fisiológicas para } \\
\text { categorias } \\
\text { específicas de } \\
\text { doenças }\end{array}$ & $\begin{array}{l}\text { Biológicos, } \\
\text { comportamentais; } \\
\text { estilos de vida } \\
\text { inadequados à saúde }\end{array}$ & $\begin{array}{l}\text { Condições de risco biológicas, } \\
\text { psicológicas, } \\
\text { socioeconômicas, } \\
\text { educacionais, culturais, } \\
\text { políticas e ambientais }\end{array}$ \\
\hline $\begin{array}{l}\text { Principais } \\
\text { estratégias }\end{array}$ & $\begin{array}{l}\text { Vacinas, análises } \\
\text { clínicas individuais } \\
\text { e populacionais, } \\
\text { terapias com } \\
\text { drogas, cirurgias }\end{array}$ & $\begin{array}{l}\text { Mudanças de } \\
\text { comportamentos pra } \\
\text { a adoção de estilos de } \\
\text { vida saudáveis }\end{array}$ & $\begin{array}{l}\text { Coalizões para a advocacia e } \\
\text { ação política; promoção de } \\
\text { espaços saudáveis; } \\
\text { empoderamento da população; } \\
\text { desenvolvimento de } \\
\text { habilidades, conhecimentos e } \\
\text { atitudes; reorientação dos } \\
\text { serviços de saúde. }\end{array}$ \\
\hline
\end{tabular}

Figura 3: Abordagens de saúde e diferenças entre prevenção e promoção. Adaptado de WESTPHAL, 2006, p.649. 
A crítica que se coloca a essa classificação é que ela parte de uma visão de certa forma idealizada do conceito de saúde, no qual o ideal de "total bem-estar", proposto pela OMS em 1946, ainda está presente, mesmo que com outra roupagem. Nesse sentido, as observações a essa definição e seu caráter utópico, tais como expostas anteriormente, assim como as realizadas por Ayres acerca dos problemas relativos à polarização entre os conceitos de saúde e de doença, continuam válidas.

Além disso, nos parece que a diferenciação feita por Westphal acerca das ações voltadas à prevenção de doenças daquelas voltadas à promoção da saúde não se referem ao foco central da ação (ligado ou não a uma doença ou agravo, tendo como base a ideia de risco específico), mas sim relacionadas ao conjunto de determinantes (mais ou menos amplos) que são considerados na execução e planejamento das ações.

De fato, as diferenças existentes entre promoção da saúde e prevenção de doenças são bastante difusas quanto à implementação de estratégias, ficando mais claras no campo teórico e na explicitação de seus pressupostos.

Como procuramos apresentar nesse capítulo, o tema da saúde é por natureza complexo, na medida em que existem distintas compreensões de seu significado, tanto nos seus aspectos individuais quanto coletivos. Além disso, as diversas vertentes de pensamento que foram constituídas ao longo da história para a explicação e compreensão do processo saúde-doença conformam distintas abordagens ao tema, assim como diversas estratégias para a melhoria da situação de saúde das pessoas ou grupos.

Nesse sentido, buscamos delimitar teoricamente essas diversas perspectivas a partir da apresentação de suas origens históricas, a fim de demarcar os limites e possibilidades de cada uma. Além disso, buscamos definir e compreender conceitualmente alguns dos termos e ideias que vêm permeando a discussão acerca da saúde e das estratégias para sua melhoria, incluindo a educação.

A esse respeito, e especificamente no que tange ao livro didático, essas distintas compreensões definem abordagens distintas ao tema, que podem ser apreendidas por meio da análise dos conteúdos apresentados (sua seleção e encadeamento lógico), da ênfase e do papel atribuído aos diversos aspectos determinantes do processo saúde-doença, do enfoque de caráter individual ou coletivo, da natureza das orientações e dos objetivos pedagógicos e propósitos educacionais expressos nesses materiais. 


\section{A SAÚDE NA ESCOLA}

\subsection{Breve Histórico}

A incorporação dos temas relacionados à saúde humana no ambiente escolar brasileiro tem sua origem no final do século XIX e início do XX a partir de duas grandes vertentes (COLLARES e MOYSES, 1985). A primeira, referente aos serviços de saúde escolar vinculados à pasta da Educação, diz respeito às ações que passaram a ser desenvolvidas a partir do final do século XIX e principalmente após 1910, que, ao assimilar os pressupostos higienistas vigentes à época, tinham como objetivos "promover e vigiar o saneamento do ambiente escolar e a saúde das crianças, criando condições necessárias para a aprendizagem." (COLLARES e MOYSES, 1985, p. 13).

Coerentemente com as ações voltadas à melhoria das condições sanitárias da sociedade que passaram a ser desenvolvidas no Brasil vinculadas à "era do germe" (NUNES, 1998) - tendo a ação de Oswaldo Cruz como marco -, a escola passou a ser considerada como um espaço privilegiado para o desenvolvimento de práticas voltadas à melhoria das condições sanitárias de uma parcela significativa da população, as crianças, por meio da ênfase na higiene, tanto física como dos "modos de ser". Sob essa perspectiva,

a prescrição de um elenco de preceitos e práticas a serem institucionalizados no espaço público da escola, pretendendo ordenar a vida dos escolares sob um novo modo de relação com o mundo - a higiene - constituiu o cerne do discurso nascente da saúde escolar, então higiene escolar. (LIMA, 1985, p.54).

Assim, a utilização dos princípios da higiene como instrumento de normatização, vigilância e saneamento da sociedade, tanto nos seus aspectos físicos quanto comportamentais (FOLCAULT, 1979), passa a adentrar na escola, em função da sua possibilidade de atingir uma grande parcela da população em uma idade considerada ideal para o desenvolvimento de hábitos, valores, práticas e atitudes relacionadas à saúde.

Aspectos relacionados à arquitetura escolar, às condições de infraestrutura, à regulamentação e orientação nutricional da merenda escolar, aos exames antropométricos e para a detecção de possíveis agravos ou deficiências na população escolar (comumente realizados pela disciplina de Educação Física) são exemplos desse tipo de incorporação da saúde pela escola. (LIMA, 1985). 
Baseada em preceitos originários da área da saúde e a partir de sua racionalidade científica, fundamentada principalmente na fisiologia (LIMA, 1985), a saúde escolar passa a fazer parte do ambiente da escola definindo ações e prescrevendo intervenções durante todo o século XX. Atinge seu ápice a partir da década de 1950, quando

a grande ação da área da saúde sobre o espaço escolar não se daria mais
como uma prescrição de modos de viver, mas sim como uma intervenção
direta e violenta no modo de ser da escola. [...] quando a merenda escolar
iria tomando corpo até chegar à soberania de 'razão de ser' da escola na
década de 1970. A merenda devia existir, no discurso oficial, não por ser
algo natural em um ambiente onde existem crianças que, por serem crianças,
sentem fome. Ela devia existir como atrativo para que a criança pobre,
famélica e desnutrida procurasse a escola. (LIMA, 1985, p.56).

Nesse sentido, a presença na escola passa a ser oficialmente o meio de acesso à alimentação, por meio da merenda escolar, para as crianças das parcelas mais pobres da população. Levada ao extremo, a perspectiva da saúde escolar como exposta na citação acima, acaba por transformar o objetivo final da escola, que deixa de ter como função principal o processo ensino-aprendizagem e passa a ser vista como espaço privilegiado para o desenvolvimento de ações voltadas à saúde das crianças, explicitamente de caráter assistencialista, sendo este o propósito final e a razão de ser da instituição escolar.

A segunda vertente diz respeito à incorporação dos conteúdos relacionados à saúde no currículo escolar, onde conceitos, informações, valores, atitudes e práticas relacionadas ao tema passam a fazer parte dos conteúdos a serem desenvolvidos em sala de aula. Ou seja, a saúde passa a ser compreendida não mais apenas como passível de intervenção no espaço e na dinâmica escolar, mas também como objeto de trabalho dos professores e de estudo e aprendizagem por parte dos alunos.

É possível dizer que esse movimento de incorporação curricular se deu basicamente a partir de três modelos ou formas. A primeira, e mais frequente, é realizada a partir do desenvolvimento de atividades relacionadas a temas específicos, tais como ações em função de campanhas específicas vinculadas ao setor saúde (saúde bucal, vacinação, prevenção de acidentes, combate às drogas, dengue, dentre outras) ou aquelas relacionadas às visitas ou a realização de "palestras" por profissionais de saúde na escola em função de temas específicos. Planejadas em função da agenda do setor saúde (campanhas de vacinação, datas nacionais voltadas à prevenção etc.) ou a partir de contatos e demandas pessoais, são caracterizadas por seu caráter pontual e episódico, assim como pela frágil articulação com os conteúdos desenvolvidos em sala de aula. Além disso, a entrada de profissionais da saúde no ambiente 
escolar acaba por deslegitimar a ação e o discurso dos profissionais da educação e mais especificamente do professor em assuntos relativos ao tema. Ou seja, se é preciso que profissionais externos sejam convidados para que palestras ou atividades específicas sejam desenvolvidas, parece-nos claro que há o entendimento de que os docentes não são capazes de desenvolver tais conteúdos ser esse auxilio da autoridade externa.

Um segundo modelo diz respeito aos programas de caráter intersetorial que visam articular as áreas da Saúde e da Educação com vistas ao desenvolvimento de ações de saúde na escola que tenham um caráter mais processual e contínuo. Recentemente, o governo federal busca realizar essa articulação por meio do Programa Saúde na Escola (PSE). O PSE $^{19}$, vinculado aos Ministérios da Educação e da Saúde, define como objetivo final “contribuir para a formação integral dos estudantes da rede pública de educação básica por meio de ações de prevenção, promoção e atenção à saúde" (BRASIL, 2007). Abarca atualmente diversas ações e programas tais como o Programa Saúde e Prevenção na Escola (SPE) relacionado à saúde sexual e reprodutiva e à prevenção das Doenças Sexualmente Transmissíveis e Aids, programas relacionados à merenda escolar, ao incentivo à prática de atividades físicas, à saúde bucal, dentre outros.

Finalmente, a incorporação de temas da saúde como objeto de trabalho escolar também é realizada a partir da definição de objetivos e conteúdos relacionados à saúde que devem ser desenvolvidos tanto por disciplinas específicas quanto transversalmente ao currículo. Nesse caso, a saúde passa a fazer parte do rol de conteúdos a ser desenvolvido em sala de aula pelos professores e, nesse sentido, os materiais de apoio, especialmente o livro didático, passam a exercer papel importante para professores e alunos. Dado o objetivo e o escopo do presente trabalho, é essa última modalidade de inserção da saúde no cotidiano escolar que será discutida a seguir.

\subsection{O marco legal}

A despeito de sua presença poder ser verificada em livros didáticos no Brasil desde o final do Século XIX e início do XX com conteúdos vistos, por exemplo, nas obras de Ferreira (1894) ou Milano (1922), o que aponta que a saúde, e especificamente a higiene, se constitui como objeto de estudo dos alunos desde essa época, os temas relativos à saúde humana

\footnotetext{
${ }^{19}$ Criado a partir do decreto presidencial no 6.286, de 5 de dezembro de 2007.
} 
passaram a ser inseridos de maneira obrigatória nas propostas curriculares para a Educação Básica no Brasil em 1971, a partir da promulgação da lei 5.692/71.

Em seu artigo $7^{\circ}$, a referida legislação definia que "será obrigatória a inclusão de Educação Moral e Cívica, Educação Física, Educação Artística e Programas de Saúde nos currículos plenos dos estabelecimentos de $1^{\circ}$ e $2^{\circ}$ graus" (BRASIL, 1971), com o objetivo de estimular o conhecimento e a prática da saúde básica e da higiene, assim como "estimular e guiar o desenvolvimento físico e mental da criança e estabelecer nela sólidos hábitos de saúde." (BAGNATO, 1990, p.54).

Claramente, a ideia que baseia essa formulação é a compreensão de que a escola é um lócus privilegiado para a aquisição ou mudança de hábitos relacionados à saúde, sendo esse desenvolvimento o objetivo final dessa incorporação da saúde como objeto da ação pedagógica no ambiente escolar.

Os programas de saúde propostos pela lei 5.692/71 tiveram suas diretrizes relacionadas à concepção de saúde a ser adotada, aos princípios da educação da saúde ${ }^{20}$, aos objetivos a serem alcançados e aos conteúdos a serem desenvolvidos por meio do Parecer 2.246/74, aprovado em agosto de 1974 pelo Conselho Federal de Educação (CFE). Apesar de esses documentos terem sido elaborados a cerca 40 anos e em um contexto político e institucional bastante distinto do atual, é importante sua análise, pois é possível perceber que muito de seu conteúdo exerceu e vem exercendo influência na definição das diretrizes e documentos de referência elaborados posteriormente e continua balizando a definição dos objetivos e dos conteúdos relacionados à saúde atualmente presentes nos livros didáticos.

Quanto ao parecer do CFE, ao assumir como premissa a definição de saúde formulada pela OMS como "completo bem-estar", a relatora ${ }^{21}$ justifica sua escolha do seguinte modo:

A preferência dada à conceituação da OMS prendeu-se não só no desejo de ter o respaldo da autoridade inconteste daquele órgão, mas também porque $o$ enfoque daquela conceituação se faz no indivíduo. Ainda que se possa focalizar a saúde como um estado de equilíbrio ecológico, e possa a

\footnotetext{
${ }^{20}$ O termo "educação da saúde" adotado no parecer é criticado por Mohr (2002), que afirma denotar um entendimento único da saúde, ou que existe apenas um único tipo de saúde considerado bom, "a saúde”. A esse respeito, a relação entre educação e saúde é permeada por diversos termos (educação em saúde, educação popular em saúde, educação e saúde, educação para a saúde, educação sanitária, dentre outros) que apontam para distintas perspectivas e visões tanto da educação como da saúde, e determinam objetivos e campos de atuação bastante diversificados. Essa discussão é apontada pelos seguintes autores, dentre outros: Mohr (2002), Valadão (2004), Vasconcelos (2001).
}

21 Conselheira Prof ${ }^{a}$. Edília Coelho Garcia 
educação ser encarada no seu contexto ecológico e ecológico-social, é para o indivíduo e sua ação que ela deve-se dirigir prioritariamente. O objeto e os objetivos do ensino da saúde na escola devem centrar-se no indivíduo e na sua formação e é para esses que se dirigem o interesse e a vocação do educador. (BRASIL, 1974, pp.64-65, grifos nossos).

Claramente, o enfoque individual é aquele a ser privilegiado e, coerentemente, as questões relativas à aquisição de hábitos "saudáveis" - em especial aqueles ligados à higiene do corpo, mas também relacionados às atitudes e comportamentos - são os objetivos a serem atingidos. Esses objetivos valorizam o aspecto comportamental, na medida em que "enfatizam a criação de hábitos e atitudes e, subsidiariamente, a aquisição de conhecimentos básicos que justificam, alicerçam e tornam compreensíveis, aqueles hábitos e atitudes" (BRASIL, 1974, p.68, grifo nosso).

No que diz respeito às séries iniciais do Ensino Fundamental ( $1^{\circ}$ grau à época) o enfoque nos hábitos de higiene fica mais evidenciado, pois o parecer define que "nas primeiras séries de $1^{\circ}$ grau [o ensino da saúde] será sempre desenvolvido como atividade, visando principalmente à criação e a manutenção de hábitos de higiene.” (BRASIL, 1974, p.71).

Além disso, é explicitada a compreensão de que os problemas de saúde são diretamente ligados a esses hábitos e comportamentos e que cabe ao indivíduo a responsabilidade por sua própria saúde. Ou seja, a saúde é entendida como uma questão de escolha e de responsabilidade estritamente pessoal, a partir de uma visão claramente comportamentalista:

é evidente que o objetivo final da educação da saúde é a aquisição de um comportamento adequado quanto aos problemas de saúde, pois só esse comportamento pode favorecer a conservação e a promoção da saúde individual e coletiva. (BRASIL, 1974, p.70).

Há que se destacar ainda o caráter pragmático e prático desses programas que deveriam ser, segundo o parecer, desenvolvidos muito mais por meio de atividades práticas do que por meio do desenvolvimento de conteúdos específicos. Além disso, os programas de saúde não necessariamente deveriam ser desenvolvidos em todas as séries do $1^{\circ}$ e $2^{\circ}$ graus e deveriam abarcar diversas áreas do conhecimento, não sendo objeto de nenhuma das disciplinas escolares, aparecendo aqui as bases do que futuramente será definido pelos Parâmetros Curriculares Nacionais em 1997 como caráter transversal do desenvolvimento do tema. Coerentemente a essa perspectiva não exigia nenhum tipo de formação específica do professor ou professores responsáveis pelo desenvolvimento dos referidos programas. 
$\mathrm{Na}$ década de 1990, portanto em um momento posterior ao movimento de redemocratização do país, o ensino da temática passou a ser incorporado às Diretrizes Curriculares Nacionais para o Ensino Fundamental, que apontavam ser a saúde um dos componentes da Base Comum Nacional $(\mathrm{BCN})$ que "deve integrar-se em torno do paradigma curricular" em todas as escolas no Brasil, a fim de "legitimar e qualificar a ação pedagógica na diversidade nacional.” (BRASIL, 1998a, p.01). A partir dessa definição, a saúde passou a compor o conjunto de conteúdos que deveriam ser obrigatoriamente desenvolvidos em todas as escolas do território nacional (BRASIL, 1998a).

No parecer CEB 04/98 do Conselho Nacional de Educação (CNE), que homologa as Diretrizes Curriculares de 1998, o ensino de temas relacionados à saúde é justificado em função de sua importância na formação integral do aluno a partir da sua relação com a Vida Cidadã, entendida da seguinte forma:

O significado que atribuímos à Vida Cidadã é o do exercício de direitos e deveres de pessoas, grupos e instituições na sociedade, que em sinergia, em movimento cheio de energias que se trocam e se articulam, influem sobre múltiplos aspectos, podendo assim viver bem e transformar a convivência para melhor. (Brasil, 1998b, p.09)

A partir dessa definição o parecer aponta que,

as escolas, com suas propostas pedagógicas, estarão contribuindo para um projeto de nação, em que aspectos da Vida Cidadã, expressando as questões relacionadas com a Saúde, a Sexualidade, a Vida Familiar e Social, o Meio Ambiente, o Trabalho, a Ciência e a Tecnologia, a Cultura e as Linguagens, se articulem com os conteúdos mínimos das Áreas de Conhecimento. (Brasil, 1998b, p.09)

Atualmente, no que tange ao Ensino Fundamental, as Diretrizes Curriculares Nacionais para o Ensino Fundamental de 9 (nove) anos (BRASIL, 2010a) definem um conjunto de princípios éticos, políticos e estéticos a serem adotados como norteadores das políticas e das ações pedagógicas das escolas e sistemas de ensino. Entre seus princípios políticos está o

reconhecimento dos direitos e deveres de cidadania, de respeito ao bem comum e à preservação do regime democrático [...]; da busca da equidade no acesso à educação, à saúde, ao trabalho, aos bens culturais e outros benefícios; (BRASIL, 2010a, p.02).

Mesmo não definindo a saúde como componente da BCN - diferentemente, portanto, da legislação de 1998 - as atuais diretrizes definem que 
os componentes curriculares e as áreas de conhecimento devem articular em seus conteúdos, a partir das possibilidades abertas pelos seus referenciais, da abordagem de temas abrangentes e contemporâneos que afetam a vida humana em escala global, regional e local, bem como na esfera individual. Temas como saúde, sexualidade e gênero, vida familiar e social [...] devem permear o desenvolvimento dos conteúdos da base nacional comum e da parte diversificada do currículo. (BRASIL, 2010a, p.05).

O Parecer do Conselho Nacional de Educação, referente a essas Diretrizes (BRASIL, 2010b), explicita a dimensão valorativa relaciona à saúde ao afirmar que

a ciência que a escola ensina está impregnada de valores que buscam promover determinadas condutas, atitudes e determinados interesses, como por exemplo, a valorização e preservação do meio ambiente, os cuidados com a saúde, entre outros. (BRASIL, 2010b, p.11).

Somado a isso, o referido parecer, ao discutir as orientações para a escola de tempo integral, aponta que atividades de promoção da saúde devem fazer parte do conjunto de atividades propostas pelas escolas que adotarem essa modalidade de ensino.

O currículo da escola de tempo integral, concebido como um projeto educativo integrado, deve prever uma jornada escolar de, no mínimo, 7 (sete) horas diárias. A ampliação da jornada poderá ser feita mediante o desenvolvimento de atividades como as de acompanhamento e apoio pedagógico, [...] preservação do meio ambiente, promoção da saúde, entre outras, articuladas aos componentes curriculares e áreas de conhecimento, bem como as vivências e práticas socioculturais. (BRASIL, 2010b, p.25).

Adicionalmente, ambos os documentos (diretrizes e parecer) afirmam ser a "área da saúde" como uma das fontes teóricas nas quais as diversas disciplinas escolares devem se apoiar para a definição dos conceitos e dos conteúdos a serem desenvolvidos, tanto na Base Comum, quanto na parte diversificada do currículo.

É importante destacar que atualmente não há nenhum documento oficial que aponte para concepções ou perspectivas para o ensino dos temas relacionados à saúde na escola, seja por meio de sua incorporação nas propostas curriculares, seja pelo desenvolvimento de programas e projetos específicos. A atual legislação apenas reafirma a importância do desenvolvimento do tema como fundamental para a construção da cidadania e para o desenvolvimento integral do aluno, na medida em que a saúde se configura como um dos "temas abrangentes e contemporâneos que afetam a vida humana em escala global, regional e local, bem como na esfera individual”. (BRASIL, 2010a, p.05).

Nesse sentido, é importante destacar que desde o estabelecimento da obrigatoriedade da inclusão de temas relacionados à saúde nos currículos escolares definido pela Lei 5.692/71, 
apenas dois documentos oficiais, o parecer 2.246/74 do Conselho Federal da Educação (de caráter obrigatório) e os Parâmetros Curriculares Nacionais (não obrigatórios) procuraram apontar concepções e perspectivas para o desenvolvimento dos temas relacionados à saúde humana no cotidiano escolar, podendo, portanto ser considerados como marcos nessa trajetória.

\subsection{A saúde nos Parâmetros Curriculares Nacionais}

Os Parâmetros Curriculares Nacionais (PCN), publicados em 1997, mesmo não tendo caráter obrigatório e, em muitos casos, sofrendo severas críticas quanto aos seus conteúdos e perspectivas de ensino - dentre essas realizadas por Adriana Mohr (2002) referente ao tema da saúde - afirmam a importância do desenvolvimento da temática da saúde, quando definem "Ser Humano e Saúde" como um dos blocos temáticos de conteúdos da disciplina Ciências Naturais (assim como Ambiente, Recursos Tecnológicos e Terra e Universo) para o primeiro e segundo ciclos do Ensino Fundamental (BRASIL, 1997a, p.52). Além disso, definem também a saúde como um dos "Temas Transversais" que devem ser desenvolvidos, de maneira transversal ao currículo, pelo conjunto de disciplinas escolares. (BRASIL, 1997b).

A análise das orientações relacionadas à saúde presentes nos PCN é importante, pois esses documentos, independentemente de seu caráter não obrigatório e a despeito de terem sido publicados há mais de uma década, continuam a exercer forte influência na elaboração dos livros didáticos. Exemplos claros dessa influência puderam ser vistos na presente investigação, na medida em que muitas das coleções analisadas trazem textos de apresentação claramente relacionados aos textos dos Parâmetros, especialmente aqueles referentes à natureza e objetivos do ensino de Ciências para o Ensino Fundamental. Além disso, diversas coleções adotam como estrutura os mesmos blocos temáticos dos PCN, explicitam e nomeiam o trabalho com "temas transversais" quando propõem atividades e discussões que envolvam aspectos relacionados à saúde e definem boa parte do conteúdo a ser desenvolvido a partir das orientações dadas por esses documentos.

Além disso, alguns autores afirmam que a aproximação ou distanciamento das orientações dos PCN ainda pode ser considerado como um dos critérios de escolha dos livros didáticos por parte dos professores, o que faz com que os PCN exerçam grande influência na produção desse material. (LIMA e SILVA, 2010; FREITAS e MARTINS, 2009; CARNEIRO, dos SANTOS e MOL, 2005). 
Vale ressaltar que, em função dos objetivos propostos no presente trabalho, as referências utilizadas na análise dos PCN dizem respeito àqueles referentes aos anos iniciais do Ensino Fundamental $\left(1^{\circ}\right.$ ao $\left.5^{\circ}\right)$ denominados, em função da legislação vigente à época de sua publicação, como "primeiro e segundo ciclos", ou "séries iniciais" do Ensino Fundamental. Portanto, não serão objeto de análise os Parâmetros para as séries finais do Ensino Fundamental (antiga $5^{\mathrm{a}}$ a $8^{\mathrm{a}}$ séries, atuais $6^{\circ}$ a $9^{\circ}$ anos) e para o Ensino Médio (PCNEM).

No que diz respeito às expectativas gerais relacionadas ao Ensino Fundamental, os PCN se referem especificamente ao tema da saúde na definição de um dos objetivos gerais a serem alcançados ao final desse ciclo escolar, na medida em que é esperado

que os alunos sejam capazes de conhecer e cuidar do próprio corpo, valorizando e adotando hábitos saudáveis como um dos aspectos básicos da qualidade de vida e agindo com responsabilidade em relação à sua saúde e à saúde coletiva.(BRASIL, 1997a, p.05).

Nesse sentido, fica evidente o entendimento da saúde relacionada a um conjunto de hábitos e atitudes a serem desenvolvidas, tendo a escola como espaço privilegiado para esse desenvolvimento. Para tanto, é enfatizada a necessidade da adoção de um posicionamento "responsável" em relação às escolhas que determinam a situação de saúde, o que traz novamente a ideia da saúde a partir das escolhas pessoais.

Quanto à relação entre o ensino das Ciências Naturais e a Saúde, os Parâmetros apontam que um dos objetivos gerais da área para o Ensino Fundamental é "compreender a saúde como um bem individual e comum que deve ser promovido pela ação coletiva" (BRASIL, 1997a, p.31), o que aponta para uma perspectiva da saúde entendida como um "bem" e não apenas na sua dimensão individual, mas também coletiva. A partir desse objetivo, define "ser humano e saúde" como um dos "blocos temáticos" da disciplina que, segundo o mesmo documento, têm como função na estruturação curricular da área "sugerir conteúdos, indicando também as perspectivas de abordagem." (BRASIL, 1997a, p.34, grifo nosso).

Ao apresentar o bloco temático "Ser Humano e Saúde", o documento afirma que

o equilíbrio dinâmico, característico do corpo humano é chamado de estado de saúde. Pode-se então compreender que o estado de saúde é condicionado por fatores de diversas ordens: físicos, psíquicos e sociais. A falta de um ou mais desses condicionantes da saúde pode ferir o equilíbrio e, como consequência o corpo adoece [...]. O estado de saúde ou de doença decorre da satisfação ou não das necessidades biológicas, afetivas, sociais e culturais, 
que, embora sejam comuns, apresentam particularidades em cada indivíduo, nas diferentes culturas e fases da vida. (BRASIL, 1997a, p.39, grifos nossos).

Nessa definição é importante destacar a concepção de saúde como equilíbrio relacionado a fatores de diversas naturezas. No entanto, a saúde é tratada como um estado e não um processo, um continuum (processo saúde-doença). Ou seja, é possível dizer que nessa afirmação está subjacente o entendimento da saúde a partir de uma dicotomia entre o estado saudável e o enfermo, ou, retomando Canguilhem, entre o normal e o patológico.

Além disso, ao afirmar que a falta de um dos condicionantes pode vir a comprometer esse estado e, por consequência “o corpo adoece", reafirma essa dicotomia e não se considera que tais fatores não podem ser analisados pela sua presença ou ausência, pois não podem ser considerados como presentes ou ausentes na vida das pessoas. Em outras palavras, é possível existir falta de condicionantes biológicos, culturais ou sociais? Ou, em que medida esses condicionantes aparecem como ausentes ou presentes, já que dependem das necessidades individuais e devem ser analisadas em função de sua relação e influência na situação de saúde dos indivíduos e da população?

No volume de apresentação dos "temas transversais," justifica-se a pertinência de se abordar determinados temas durante o Ensino Fundamental, "de maneira transversal às disciplinas escolares e sem se constituir como uma disciplina específica” (BRASIL, 1997b, p.23), a partir da constatação de que "há questões urgentes que devem necessariamente ser tratadas, como a violência, a saúde, o uso dos recursos naturais, os preconceitos, que não têm sido diretamente contemplados por essas áreas [as disciplinas escolares tradicionalmente constituídas]" (BRASIL, 1997b, p.23). A partir dessa premissa, os temas que deverão fazer parte das propostas curriculares foram escolhidos a partir de critérios relacionados à urgência social, à abrangência nacional, à possibilidade de ensino e aprendizagem no Ensino Fundamental e à possibilidade de compreensão da realidade e participação social. Dentre eles, aparece o tema da saúde.

É interessante notar que no mesmo documento sugere-se que "existem afinidades" entre alguns temas transversais e áreas do conhecimento ou disciplinas escolares "como é o caso de Ciências Naturais e Saúde" 22 (BRASIL, 1997b, p.32), afinidade essa que pode

\footnotetext{
${ }^{22}$ Além dessa "afinidade" com as Ciências Naturais, os PCN sugerem também que questões relacionadas à saúde devem fazer parte dos objetivos relacionados à Educação Física. A esse respeito o volume específico dessa disciplina define como um dos objetivos da área para o Ensino Fundamental "que o aluno seja capaz de reconhecer-se como elemento integrante do ambiente, adotando hábitos saudáveis de higiene, alimentação e
} 
justificar muito da incorporação dos conteúdos e dos objetivos propostos para a Educação para a Saúde nos livros didáticos de Ciências.

No volume específico do "tema transversal saúde", fica clara a adoção de uma concepção bastante bem alinhada aos pressupostos da Saúde Coletiva, em especial às ideais de que a saúde deve ser entendida como um processo (processo saúde-doença), que é determinado por condicionantes biológicos e pelos meios físico, socioeconômico e cultural. "Não se pode compreender ou transformar a situação [de saúde] de um indivíduo ou de uma comunidade sem levar em conta que ela é produzida nas relações com o meio físico, social e cultural." (BRASIL, 1997c, p.65). Adicionalmente, a ideia de saúde como um direito universal permeia todo o documento, com referências aos princípios de integralidade, equidade e universalidade de acesso, constituintes do Sistema Único de Saúde do Brasil (SUS).

Sua inclusão [da educação para a saúde] no currículo responde a uma forte demanda social, num contexto em que a tradução da proposta constitucional [que afirma ser a saúde um direito do cidadão e um dever do Estado] em prática requer o desenvolvimento da consciência sanitária da população e dos governantes para que o direito à saúde seja encarado como prioridade. (BRASIL, 1997c, p.65)

Fundamentalmente, o documento propõe uma abordagem curricular do tema baseada em ideias advindas do movimento da Promoção da Saúde ao afirmar que "na abordagem apresentada, a educação é considerada um dos fatores mais significativos da promoção da saúde" (BRASIL 1997c, p.61). A esse respeito, aponta que

a promoção da saúde se faz por meio da educação, da adoção de estilos de vida saudáveis, do desenvolvimento de aptidões e capacidades individuais, da produção de um ambiente saudável. Está estreitamente vinculada, portanto, à eficácia da sociedade em garantir a implantação de políticas públicas voltadas para a qualidade de vida e ao desenvolvimento da capacidade de analisar criticamente a realidade e promover a transformação positiva dos fatores determinantes da condição de saúde. (BRASIL, 1997c, p. 67).

Está bastante claro nessa afirmação o entendimento da promoção da saúde como um aspecto relacionado ao indivíduo, na medida em que são enfatizados termos como "estilo de vida" e "aptidões e capacidades individuais", assim como a sua dimensão coletiva e de 
posicionamento crítico frente à realidade a fim de "analisar criticamente a realidade" para transformar os determinantes de saúde. Transita, portanto, entre uma visão conservadora da promoção da saúde, voltada ao indivíduo e suas escolhas, e uma visão progressista que enfatiza as mudanças das condições desfavoráveis à saúde (CZERESNIA, 2009), alinhandose, dessa forma, à própria definição da OMS para p termo.

A esse respeito, a necessária relação entre as dimensões individual e coletiva inerente à compreensão do processo saúde-doença como diretriz para o ensino da saúde fica evidente no documento, ao afirmar que

os enfoques segundo os quais a condição de saúde individual é determinada unicamente pela realidade social ou pela ação do poder público, tanto quanto a visão inversa, nem por isso menos determinista, que coloca todo peso no indivíduo, em sua herança genética e em seu empenho pessoal, precisam ser rompidos [nas propostas para o ensino do tema].(BRASIL, 1997c, p.65).

Em função de sua relação com a proposta de promoção da saúde, um dos focos do documento diz respeito à crítica feita à tradição de desenvolvimento do tema na escola, que é exposta do seguinte modo já em sua apresentação:

o ensino de saúde tem sido um desafio para a educação no que se refere à possibilidade de garantir uma aprendizagem efetiva e transformadora de atitudes e hábitos de vida. As experiências mostram que transmitir informações a respeito do funcionamento do corpo e a descrição das doenças, bem como um elenco de hábitos de higiene, não é suficiente para que os alunos desenvolvam atitudes de vida saudável. (BRASIL, 1997c, p.61).

Essa crítica se faz mais explicitamente na proposição das diretrizes para o ensino da temática, onde o documento propõe uma diferença entre os termos "ensinar saúde" e "educar para a saúde", enfatizando a necessidade do desenvolvimento de atitudes e valores favoráveis ao desenvolvimento da saúde como um todo, características, segundo o MEC, da segunda perspectiva de ensino (ou o "educar para a saúde").

No primeiro caso (ensinar saúde) o foco é colocado numa formação sobre saúde e na coincidência de conceitos que fundamentou a proposta clássica de inserção dos programas de saúde no escopo da disciplina Ciências Naturais. Entretanto, essa estratégia não se revelou suficiente para a garantia de abordagem dos conteúdos relativos aos procedimentos e atitudes necessários à promoção da saúde [...]. Isso não quer dizer que as informações e a possibilidade de compreender a problemática que envolve as questões de saúde não tenham importância ou que não devam estar presentes no processo de ensinar e aprender para a saúde, mas sim que a Educação para a Saúde só será efetivamente contemplada se puder mobilizar as necessárias mudanças na busca de uma vida saudável. (BRASIL, 1997c, p.69). 
Essa diferença de abordagem é justificada pela constatação de que a informação isolada e descontextualizada é pouco efetiva para as mudanças esperadas e que "o 'biologismo' - que valoriza a anatomia e a fisiologia para explicar a saúde e a doença -, não dá conta dessa tarefa [de desenvolvimento de atitudes e hábitos favoráveis à saúde]" (BRASIL, 1997c, p.69).

É pertinente apontar que essa crítica à ênfase dada aos aspectos biológicos na compreensão do processo saúde-doença tem origem nas discussões do campo da Epidemiologia social e da Saúde Coletiva, e mais recentemente se relaciona à Promoção da saúde, a partir do entendimento que os aspectos biológicos são um dentre outros que interferem na situação de saúde das pessoais e das populações, o que é bastante coerente com a perspectiva adotada pelos PCN. Parece-nos ser essa a origem do termo "biologismo" empregado pelo MEC a fim de chamar a atenção para esse aspecto.

A esse respeito, Mohr (2002) faz uma severa crítica ao uso desse termo pelo MEC que, segundo a autora, aponta para uma desvalorização dos conteúdos específicos relacionados à biologia em detrimento do desenvolvimento de atitudes e valores, crítica essa que se coaduna com diversas críticas aos PCN de maneira geral. Além disso, a autora afirma que essa crítica denota uma visão equivocada, e de certo modo ultrapassada, por parte dos autores do documento, a respeito do atual estágio do ensino da Biologia.

Mesmo considerando a importância da crítica realizada por Mohr, vale destacar que o PCN relacionado à saúde deixa claro que não há a desconsideração dos conteúdos e conceitos das Ciências Naturais (ou da Biologia) na abordagem proposta ao afirmar que

os detalhes relativos a processo fisiológicos ou patológicos ganharão sentido no processo de aprendizagem na medida em que contribuírem para a compreensão das ações de proteção à saúde a eles associados. (BRASIL, 1997c, p.69).

Portanto, a crítica feita pelo PCN - ou o "biologismo"- não aponta para uma desconsideração dos conteúdos da área, mais sim chama a atenção para umaa abordagem que, segundo os autores do documento, é hegemônica nas Ciências Naturais que, ao enfatizar a descrição da doença a partir de seus aspectos biológicos, privilegia o discurso acerca da doença e não da saúde. Aponta para uma discussão que tem origem no campo da Saúde Coletiva, e mais recentemente se relaciona ao movimento da Promoção da saúde, a partir do entendimento que os aspectos biológicos são um dentre outros que interferem na situação de 
saúde das pessoais e das populações, o que é bastante coerente com a perspectiva adotada pelos PCN. Parece-nos ser essa a origem do termo "biologismo" empregado pelo MEC.

Vale ressaltar que essa perspectiva que enfatiza (ou reduz) a saúde à aspectos relacionados à dimensão biológica, mesmo tendo sido o objeto principal da critica já em 1997 feita pelos PCN, se mantém atualmente em muitas coleções de livros didáticos, como verificado pela presente pesquisa. Ao desenvolverem os temas relativos à saúde (inclusive em capítulos ou unidades específicos que trazem em seus títulos o termo "saúde") tais coleções adotam um modelo para o desenvolvimento dos conteúdos que tem como foco a descrição da doença e seus sintomas, seu agente etiológico, os meios de transmissão e as medidas de prevenção (comumente de caráter individual). Esse esquema de apresentação de conteúdos, como já explorado, é marca distintiva de determinado modelo de explicação do processo saúde-doença, onde o foco está na doença e não na saúde. Ou seja, ao se proporem a falar de saúde acabam por falar de doenças.

Nesse sentido, o aspecto importante a ser ressaltado nos PCN, e na crítica que esses documentos fazem à tradição do ensino dos temas relacionados à saúde, está relacionado à importância da incorporação de discussões acerca dos fatores que extrapolam sua dimensão biológica (ou os ligados às Ciências Naturais, obviamente sem desmerecê-los). Trazem com bastante ênfase a necessidade da incorporação de discussões sobre os determinantes sociais do processo saúde-doença, ou seja, seus aspectos de caráter social, cultural, econômico, de condições de vida e moradia, de acesso aos bens e serviços, dentre outros. Além disso, estão baseados na ideia da saúde como um direito que, assim como os outros, é passível de reivindicações tanto no que diz respeito à melhoria das condições desfavoráveis, quanto relacionadas ao acesso aos serviços de assistência. Essa perspectiva aparece claramente quando da definição dos objetivos educacionais para o Ensino Fundamental:

a Educação para a Saúde cumprirá seus objetivos ao conscientizar os alunos para o direito à saúde, sensibilizá-los para a busca permanente da compreensão de seus determinantes e capacitá-los para a utilização de medidas práticas de promoção, proteção e recuperação da saúde ao seu alcance (BRASIL, 1997c, p.71)

Sem dúvida, ao enfatizar esses aspectos, os PCN adotam uma postura em relação ao desenvolvimento do tema da saúde em sala de aula que traz um importante avanço no sentido de contribuir para a sua compreensão a partir de uma visão ampliada de seus determinantes. Dessa forma, contribuem de maneira importante com a formação dos professores, em especial aqueles que trabalham com os primeiros anos do Ensino Fundamental que, dada sua formação 
de caráter generalista, tiveram pouco ou nenhum contato com a perspectiva e com referencial apresentado.

Apesar dos avanços aqui apontados relacionados aos documentos de referência para o ensino da saúde, é possível afirmar que reflexos das diretrizes traçadas, tanto da lei 5.692/71 quanto no parecer do Conselho Federal de Educação de 1974, estão presentes nas orientações atuais sobre o desenvolvimento de ações voltadas à inserção curricular da saúde.

Primeiramente, destaca-se a compreensão da escola como ambiente propício para o desenvolvimento de hábitos, atitudes e condutas favoráveis à saúde, pressuposto e princípio norteador da lei 5.692/71 e do parecer 2.246/74 e que balizou muitas das orientações propostas pelos Parâmetros Curriculares Nacionais, que apontam este aspecto como um dos objetivos da Educação para a Saúde. Cabe apontar que tal compreensão está bastante presente no conjunto das coleções didáticas analisadas, que afirmam textualmente tal premissa e assumem como objetivos relacionados à saúde o desenvolvimento e aquisição de hábitos e condutas por parte dos alunos.

A esse respeito, em um artigo datado de 1990 - anterior, portanto, à publicação dos PCN -, Bagnato (1990) afirma que da maneira como o ensino dos temas relacionados à saúde passou a ser desenvolvido a partir dos programas de saúde

parece pouco influir nos hábitos e atitudes de higiene que as crianças possuem. A família e o meio ambiente influem de maneira mais contundente nestes hábitos e atitudes, quer sejam adequados ou não. (BAGNATO, 1990, p.53).

A autora chama à atenção que

é importante lembrar que as mudanças de comportamentos relacionados com a higiene e a saúde não são asseguradas só pelo ensino da saúde; elas devem ser acompanhadas por condições adequadas de vida dos alunos e suas famílias e o ensino da saúde deve se dar mais em termos de discutir todas essas questões, contextualizando-as. (BAGNATO, 1990, p.56).

Ou seja, os hábitos e atitudes só poderão ser discutidos e incorporados (na medida do possível) a partir de propostas que estejam baseadas em aspectos relacionados não apenas à orientação e ao conhecimento sobre sua importância ou a prescrição do que é adequado ou não, ou ainda sobre o conhecimento acerca das doenças, riscos e medidas de prevenção. Essa discussão deve se realizar a partir de uma moldura mais ampla, que incorpore questões relacionadas às condições de vida, moradia, acesso aos bens e serviços, componentes culturais, econômicos, políticos etc. 
Em segundo lugar, permanece a ideia de que o tema da saúde deve ser tratado pelo conjunto de disciplinas. Sendo de responsabilidade de todo o corpo docente da escola, não cabe a nenhuma disciplina ou profissional desenvolver esse conteúdo, o que será caracterizado em 1997 pelos PCN como sendo um tema transversal ao currículo. Cabe aqui um questionamento em relação à formação profissional desejada e necessária para o desenvolvimento desse tema, na medida em que não é de responsabilidade de nenhuma das áreas o desenvolvimento das propostas. Quem são os responsáveis por elaborar as propostas, na medida em que devem levar em conta o contexto escolar e de vida dos alunos e suas famílias? Quais são os conhecimentos necessários aos professores responsáveis por essas propostas? Baseados em que conjunto de conceitos e concepções as ações são planejadas? Qual é a formação necessária para essa tarefa?

Esse problema de formação docente não é novo e é apontado como um desafio a ser superado em artigos publicados desde a década de 1980 (MOURA, 1980; LIMA, 1985; SCHALL et. al, 1987a; MOHR e SCHALL, 1992). Segundo Lima (1985), a falta de formação específica para o desenvolvimento do tema já se configurava como um dos aspectos mais preocupantes na proposta dos programas de saúde, pois tais propostas acabam por ser baseadas no "bom senso" dos professores, muitas vezes permeadas por concepções equivocadas, prescrições de caráter doutrinário e preconceitos.

Portanto, a ideia de transversalidade presente nas propostas atuais para o desenvolvimento dos temas relacionados à saúde na escola (inclusive nos livros didáticos) traz dentro de si o desafio da formação docente, pois são necessários conhecimentos originários de diversas áreas e campos de conhecimento que não estão contemplados nos cursos de formação inicial de professores (sejam eles de caráter específico ou geral) ou nas propostas de formação continuada ao longo da carreira. 


\section{O LIVRO DIDÁTICO}

\subsection{O livro didático como objeto de estudo}

O livro didático (LD), apesar dos distintos posicionamentos relacionados à sua utilização muitas vezes de maneira pouco refletida e acrítica em sala de aula ou relacionados à sua qualidade e rigor científico, é indiscutivelmente um dos principais, senão o principal, material de apoio ao processo ensino-aprendizagem tanto para alunos quanto para professores. Esse material exerce muitas vezes a função de organizador e sequenciador dos conteúdos, das atividades que deverão ser desenvolvidas e das estratégias de ensino, (FREITAG, COSTA e MOTA, 1997), "marcando, pois, de forma decisiva, o que se ensina e como se ensina o que se ensina.” (LAJOLO, 1996, p.04).

Apesar de sua investigação ter sido negligenciada por muitos anos, o livro didático passou a ser visto como objeto de pesquisa a partir de meados do século XX e, especialmente, a partir da década de 1980 (CHOPIN, 2004), configurando-se, portanto, como um campo de investigação bastante novo. Para o mesmo autor, a despeito da profusa produção atual acerca do livro didático, essa característica de "campo novo" é uma das dificuldades a serem enfrentadas pelas pesquisas relativas a esse objeto, pois são bastante raras as obras de síntese de caráter mundial que abranjam diversos períodos de sua produção e utilização. (CHOPIN, 2004).

No Brasil, a pesquisa sobre o livro didático segue mesma tendência, apresentando um grande crescimento nos últimos 20 anos. Especificamente no tocante ao livro didático de ciências, essas pesquisas apresentam, desde a década de 1990, importantes contribuições sobre aspectos relacionados às imprecisões e erros conceituais presentes nos livros (MOHR, 1994; BIZZO, 2000; SANDRIN, PUORTO e NARDI, 2005, dentre outros). Mais recentemente, essa produção discute diversos aspectos, que vão desde o processo de escolha e o significado atribuído ao LD por parte dos professores (TOLENTINO NETO, 2003; CARNEIRO, dos SANTOS e MOL, 2005; CASSAB e MARTINS, 2008; LIMA e SILVA, 2010), até relacionadas aos discursos e os gêneros discursivos utilizados nos LD (BRAGA e MORTIMER, 2003; RIBEIRO e MARTINS, 2007).

No que tange à temática da saúde, a produção nacional é bastante reduzida (FREITAS e MARTINS, 2009). Apesar de ter crescido nos últimos anos, boa parte da produção se caracteriza por analisar temas específicos, como a esquistossomose (SCHALL, et. al., 1987b), 
a abordagem relacionada às drogas psicotrópicas (CARLINI-COTRIM e ROSEMBERG, 1991), a vacinação (SUCCI, WICKBOLD e SUCCI, 2005), a saúde bucal (RIGODANZO e UNFER, 2005), as leishmanioses (FRANÇA, MARGONARI e SCHALL, 2011).

No que diz respeito à visão acerca da saúde de modo geral, Alves, em artigo da década de 1980 (ALVES, 1987), analisa uma coleção de livros destinada às (antigas) $1^{\text {a }}$ a $8^{\text {a }}$ séries, a fim de investigar como são desenvolvidos os conteúdos relativos aos programas de saúde, desenvolvidos à época por força de lei. A autora aponta que esses livros continham orientações sempre de caráter individual, relacionado às escolhas individuais e sem relação com seus determinantes sociais,

para os livros didáticos, a Saúde nunca está relacionada à questão social, às condições de vida, nem às de trabalho. Ao contrário, é sempre um caso individual, a ser obtida com base nos bons hábitos, com a ajuda do médico e da ciência. (ALVES, 1987, p.40).

Em outro trabalho no qual se buscou analisar concepções de saúde nos LD de Ciências, Mohr (1995, 2000), a partir da análise de três coleções distribuídas pelo Programa Nacional do Livro Didático no Rio de Janeiro em 1991, discute como os temas relacionados à saúde são apresentados nessas coleções. A autora expõe alguns erros conceituais presentes nos $\operatorname{livros}^{23}$, as abordagem que esses estabelecem para a saúde, assim como os critérios elaborados para a análise desenvolvida. Aponta a "péssima qualidade" dos livros, questionando inclusive sua classificação como "didáticos" (MOHR, 1994). Além disso, afirma que "as coleções analisadas não abordam a saúde ou a doença segundo o enfoque das influências dos fatores do ambiente - físicos, biológicos sociais e culturais" (MOHR, 1995, p.54) e conclui afirmando que

as coleções apresentam os programas de saúde baseados fundamentalmente em regras de higiene [...] e de prevenção de algumas verminoses, doenças contagiosas e acidentes. Na maioria das vezes, esses procedimentos são apresentados sem qualquer fundamentação teórica que os caracterizem como ações e escolhas conscientes. (MOHR, 1995, p.55).

Delizoicov (1995), ao analisar como os programas de saúde eram desenvolvidos nos livros didáticos, aponta que a saúde aparece a partir de uma concepção que privilegia a

\footnotetext{
${ }^{23}$ Vale apontar que o trabalho que deu origem aos demais textos (MOHR, 1994) foi realizado anteriormente à qualificação do processo de avaliação do LD empreendido pelo ministério da Educação a partir do Programa Nacional do Livro Didático em 1997 (PNLD 1997), que traçou entre seus principais objetivos a detecção de erros graves nos livros, sendo esse o principal critério de exclusão dos livros submetidos a essa avaliação.
} 
perspectiva individual e que atribui prioritariamente uma causa para o adoecimento (perspectiva unicausal). Além disso, a autora destaca que a saúde aparece como resultado da falta de cuidados do indivíduo permitindo, dessa forma, o aparecimento da doença.

Um traço importante que pode ser vistos a partir desses trabalhos é a hegemonia da abordagem que privilegia a dimensão individual da saúde, algo bastante coerente com as diretrizes traçadas para esses programas por meio do parecer CFE 2.246 de 1974, que leva inevitavelmente a uma tendência de responsabilização e culpabilização dos sujeitos por sua condição de saúde, algo que se alinha, atualmente, à perspectiva da promoção da saúde baseada na ideia de estilos de vida. (CASTIEL, 2007).

Recentemente, no bojo das ações do Projeto de pesquisa "A Saúde nos Livros Didáticos de Ciências para a Educação Básica" ${ }^{24}$, cujo objetivo é analisar as concepções de saúde presentes nos LD para todos os ciclos da educação básica e formular uma proposta de matriz analítica para esses materiais, vêm sendo publicados alguns trabalhos que procuram traçar uma panorâmica de como o tema da saúde vem sendo desenvolvido nos LD no Brasil (FREITAS e MARTINS, 2009; PINHÃO E MARTINS, 2010; MOREIRA, LIMA E MARTINS, 2010; MONTEIRO, BIZZO E GOUW, 2010). É possível dizer, a despeito da necessidade de maior aprofundamento e articulação entre essa produção, que alguns outros traços aparecem como hegemônicos, dentre eles destacando-se a ênfase nos aspectos biológicos da saúde, em detrimento de seus determinantes sociais, assim como a compreensão da saúde a partir do modelo biomédico e da dicotomia entre saúde e doença.

No âmbito internacional, a produção acerca da saúde nos LD também não é extensa (NOMOTO et. al., 2011). Nesse contexto, é pertinente destacar o projeto Biohead Citizen ${ }^{25}$, coordenado pela Universidade no Ninho - Portugal, que tem como objetivo compreender como o ensino da Biologia, a Educação para a Saúde e a Educação Ambiental podem promover uma melhor cidadania em 19 países da Comunidade Europeia, tendo o livro didático como um de seus objetos de investigação (CARVALHO, CLÉMENT \& BOGNER, 2004). Em trabalho decorrente desse projeto Carvalho e colaboradores (2007), ao analisarem livros didáticos de 16 países, apontam que as abordagens de saúde tendem a se deslocar de

\footnotetext{
${ }^{24}$ Projeto de pesquisa financiado pelo CNPq, desenvolvido entre os anos de 2008 e 2010, pelo Núcleo de Tecnologia Educacional para a Saúde da Universidade Federal do Rio de Janeiro (NUTES - UFRJ), pela Faculdade de Educação da Universidade de São Paulo (FEUSP) e pelo Instituto de Biologia da Universidade Federal da Bahia (IB-UFBA).

25 "Biology, Health and Environmental Education for better citizenship" (Biohead-Citizen, FP6, 2004-2008).
} 
uma perspectiva mais próxima à da promoção da saúde nos anos iniciais da escolaridade, para uma que responde às características do modelo biomédico (especialmente no que diz respeito à centralidade dos conteúdos relacionados à doença) nas séries finais da educação básica. (CARVALHO et. al., 2007). Os autores apontam que essa tendência para as séries iniciais pode ser considerada como positiva. No entanto, não discutem que pressupostos relacionados à promoção da saúde estão por trás das propostas, que podem delinear perspectivas conservadoras (relacionadas à responsabilização do sujeito) ou progressistas (de mudança das condições sociais desfavoráveis). ${ }^{26}$

Dada essa escassez de publicações que têm como objeto a saúde nos livros didáticos, e especialmente aquelas voltadas aos anos iniciais do Ensino Fundamental, a investigação aqui proposta tem o potencial de contribuir para a construção de conhecimento sobre o tema, assim como para a qualificação do próprio livro didático de Ciências para esses anos de escolaridade.

\subsection{O livro didático no mercado editorial: sua natureza e seu processo de produção}

O livro didático é historicamente no Brasil o tipo de material impresso com maior volume de produção. Chopin (2004) afirma que “[os livros didáticos] correspondiam no início do Século XX, a dois terços dos livros publicados e representavam, ainda em 1996, aproximadamente 61\% da produção nacional” (p. 551). Dados de 2009 apontam que o segmento dos "didáticos" responde por aproximadamente 53\% da produção total de livros no Brasil, com cerca de 204 milhões de exemplares produzidos em 2009, sendo142 milhões destinados às escolas públicas, por meio dos programas oficiais de compra e distribuição de livros. (CÂMARA BRASILEIRA DO LIVRO, 2010).

Dados o volume de produção e o faturamento do setor, o mercado de LD, principalmente o relacionado às compras realizadas pelos órgãos governamentais, se constitui como estratégico para a consolidação no mercado brasileiro de grupos editorias nacionais e estrangeiros (CASSIANO, 2007). Para tanto, tais grupos utilizam muitas vezes ações comerciais bastantes agressivas, com vistas à conquista de espaço nesse mercado (BIZZO,

\footnotetext{
${ }^{26}$ Os resultados desse trabalho foram recentemente apresentados em mesa redonda realizada no VIII ENPEC (Encontro Nacional de Pesquisa em Educação em Ciências) realizado em Campinas - SP, em novembro de 2011.
} 
2000) ${ }^{27}$ que, em função de sua possibilidade de penetração junto ao "público consumidor", acabam por influenciar e condicionar a escolha feita pelos professores quanto à adoção de determinadas coleções em detrimento de outras (HÖFLING, 2000).

Nesse sentido, a produção e comercialização do livro didático são atravessadas por diversos fatores que interferem de maneira decisiva na sua concepção e elaboração, influenciando a escolha do conteúdo a ser desenvolvido e sua abordagem, assim como as suas perspectivas pedagógicas e didáticas. Tendo que responder às exigências e regras impostas pelos programas oficiais do MEC, assim como às definições e decisões relacionadas ao mercado e à aceitação por parte do público (os professores), os livros didáticos podem ser vistos como um artefato que agrega aspectos não só relacionados à sua dimensão pedagógica, mas também às dimensões sociais, culturais, mercadológicas, comerciais, políticas, editoriais, empresariais etc.

É preciso reconhecer que os livros didáticos não são objetivos e factuais, mas produtos culturais que devem ser entendidos como o resultado complexo de interações mediadas por questões econômicas, sociais e culturais. Ou seja, os livros didáticos expressam a materialização de conflitos entre grupos para hegemonizar suas posições. É claro que esses conflitos não se dão num vazio econômico e social, com visível interferência, por exemplo, de um mercado editorial poderoso. (MACEDO, 2004, p.106)

Somado a esse aspecto, o livro didático procura articular diversos tipos de discursos e linguagens, além de "adaptar" os conceitos e conteúdos, a fim de propiciar a aproximação necessária desses conceitos, originários das diversas áreas do conhecimento, à realidade e contextos onde serão utilizados e às possibilidades e limites de cada faixa etária, para que possam se transformar, por meio da transposição didática, em saberes possíveis de serem aprendidos pelo conjunto de alunos. (CHEVALLARD, 1991).

A esse respeito, Braga e Mortimer (2003), ao discutirem aspectos relacionados ao texto de Biologia presente nos livros de ciências (destinados, portanto ao Ensino Fundamental), afirmam que o LD assume e utiliza um gênero discursivo distinto, "construído a partir de elementos dos gêneros de discurso científico, didático e cotidiano" (p. 72), não se configurando como

\footnotetext{
${ }^{27}$ É importante ressaltar que, no âmbito das compras governamentais, atualmente estão proibidas muitas das práticas de marketing descritas por Bizzo que eram, à época, costumeiramente utilizadas pelas editoras junto aos professores, tais como a distribuição de brindes ou presentes, a participação de autores em eventos relacionados à escolha de livros, dentre outros. (BRASIL, 2010c).
} 
a simples soma dos outros gêneros de discurso - científico, cotidiano, jornalístico, divulgação científica, pedagógico e literário [...]. Seria, na verdade, um gênero construído na relação estabelecida entre diferentes formas de discursos presentes numa mesma língua, refletindo as condições e os objetivos do meio social em que se insere - no caso, a escola. (BRAGA e MORTIMER, 2003, p.58).

Além disso, os autores afirmam que para a sua elaboração o autor do livro didático lê e apropria-se do conhecimento veiculado por textos de diversos gêneros, interpretando-os e elaborando um novo discurso, que incorpora, a partir dessa interpretação, traços dos gêneros anteriores (BRAGA e MORTIMER, 2003).

Somado a isso, no tocante ao livro didático de ciências, o conjunto de conteúdos presentes dizem respeito a uma gama muito grande de conhecimentos originários das áreas das Ciências Naturais (biologia, química e física) e de outras, tendo cada uma um determinado e próprio corpo de conhecimentos. Esse fato aponta para a necessidade da mobilização de um conjunto de autores - ou, minimamente, para um processo de assessoria técnica - que faz com que o traço individual de autoria fique diluído no seu processo de elaboração e produção.

Dados esses diversos fatores, tanto os relacionados ao processo de produção, quanto os que dizem respeito à própria construção de seu texto, sua natureza, seu conjunto de saberes, e seu significado e utilização como instrumento de trabalho do professor em sala de aula, o livro didático assume o que podemos denominar como um "caráter miscelaneoso", pois sua elaboração e produção são realizadas a partir de critérios, referências e interferências que nem sempre estão sob o controle e responsabilidade de seu autor principal ou do conjunto de seus autores.

Esse caráter de miscelânea interfere de maneira importante na proposição de investigações acerca do LD, na medida em que afirmações relacionadas à sua autoria, assim como à coerência (ou incoerência) interna ou às concepções e linhas de pensamento utilizadas precisam levar em conta seu processo de produção, que é necessariamente coletivo, atravessado por interesses de naturezas bastante distintas.

\subsection{O livro didático e seu papel em sala de aula}

No que diz respeito ao seu papel em sala da aula, Chopin (2004) sintetiza em quatro conjuntos as possíveis funções do livro no processo ensino-aprendizagem: 
Função referencial (ou programática): diz respeito ao papel do LD como suporte para os conteúdos que deverão ser desenvolvidos, ou como "depositário dos conhecimentos, técnicas ou habilidades que um grupo social acredita que seja necessário transmitir às futuras gerações" (p. 553);

Função instrumental: relacionada aos métodos de ensino e às atividades e exercícios propostos. Define, portanto, o caminho metodológico para o desenvolvimento dos conteúdos propostos, assim como a sequência das atividades e sua lógica de encadeamento;

Função ideológica e cultural: para o autor, essa é a função mais antiga do LD e tem origem no século XIX, no momento da constituição dos Estados Nacionais na Europa. Diz respeito à construção da identidade e de um projeto nacional, tendo o livro didático papel fundamental como "vetor da língua, da cultura, dos valores da classe dirigente." (p. 553). Nesse sentido, o livro didático assume o papel de propiciador de marcas curriculares que definem um projeto identitário nacional ${ }^{28}$;

Função documental: segundo Chopin, o LD pode vir a ser um instrumento valioso para desenvolver certa postura crítica no aluno, em função da leitura "não dirigida" de documentos textuais e icônicos presentes no livro, sendo um importante instrumento para o desenvolvimento da postura crítica destes frente a diversas fontes de informação. No entanto, o autor ressalta que essa função

não é universal: só é encontrada - afirmação que pode ser feita com muitas reservas - em ambientes pedagógicos que privilegiam a iniciativa pessoal da criança e visam a favorecer sua autonomia; supõe, também, um nível de formação elevado dos professores. (p.553).

Além dessas, é possível acrescentar outra função, relacionada à formação docente. $\mathrm{Na}$ medida em que os volumes destinados aos professores trazem textos de apoio às atividades que servem de referência teórica (muitas vezes a única ou a mais acessível dada à condição de acesso à literatura por grande parte dos professores no Brasil), os livros didáticos acabam por se configurar como importante veículo de atualização ou mesmo de apresentação de conceitos

\footnotetext{
${ }^{28}$ A relação entre currículo e construção da identidade é discutida por diversos autores, dentre eles Silva (2003) que afirma ser o currículo escolar uma ferramenta fundamental para a construção das identidades individuais e coletivas. Além disso, o autor aponta que os primeiros estudos acerca do currículo se deram em função da elaboração de um instrumento que garantisse a unidade e identidade nacional nos Estados Unidos da América, no início do séc. XX, quando um grande número de imigrantes (com língua, valores e ideias próprias) chegou a esse país. Afirma o autor que a obra The Curriculum: a summary of the development concerning the theory of the curriculum de John Franklin Bobbit (1918), fundante para o campo de pesquisa acerca do currículo escolar, teve como principal objetivo traçar as referências teóricas para a consolidação do currículo escolar nas escolas estadunidenses que pudessem servir como instrumento para a construção da identidade e coesão nacional.
} 
relacionados aos temas curriculares, servindo, nesse sentido, para qualificar a formação docente. Exemplo dessa função foi apontado por Fernandez e Silva (2008) que afirmam ser o livro didático de ciências, mais do qualquer outro tipo material, a principal fonte de informações e de formação relacionada à nutrição para professores do Ensino Fundamental do Distrito Federal.

Nesse sentido, o rigor e a qualidade dos textos presentes no material destinado aos professores, assim como sua relevância e pertinência podem ser considerados como elementos essenciais para a qualificação do processo ensino-aprendizagem. No caso da saúde, em função dos problemas de formação específica para o desenvolvimento do tema a partir de uma abordagem que incorpore os diversos aspectos a ele relacionados, esses textos podem se constituir como importante fonte de informação para os professores e como possibilitadores de discussões mais qualificadas e significativas junto aos alunos.

No contexto nacional e dada a desigualdade relativa ao acesso ao livro de maneira geral, o MEC explicita seu entendimento sobre o papel que o livro didático pode desempenhar, quando afirma que "o LD (Livro Didático), em qualquer disciplina, é um instrumento fundamental (às vezes praticamente o único) do acesso da 'criança popular' à leitura e à escrita” (BRASIL, 2006, p.25), sendo visto, portanto, como um dos únicos materiais escritos aos quais essas crianças têm acesso. Vale ressaltar que o termo "criança popular", segundo o MEC, foi utilizado por Darcy Ribeiro para designar as principais características socioeconômicas e culturais das crianças que frequentam a escola pública no Brasil.

Em sua maioria oriundos de camadas populares, nossos meninos e meninas fazem parte de uma cultura que a escola vem desconhecendo e, em muitos casos, negando. Sem poder aprofundar adequadamente o assunto, ainda assim convém lembrar dois de seus traços básicos: 1) muito embora não desconheça a escrita, trata-se de uma cultura eminentemente oral, com pouco convívio com materiais escritos e pequena familiaridade com o funcionamento próprio da língua escrita; 2) apesar das muitas diferenças linguísticas de caráter regional — há regiões marcadas pela presença indígena; outras, pela influência negra; em certos lugares, os imigrantes europeus é que dão o tom; e assim por diante - todas essas crianças falam, e tendem a escrever, o português popular do Brasil, que se diferencia do português culto em aspectos como o vocabulário, a estrutura das palavras, a morfologia verbal e nominal, a colocação pronominal, a estrutura da frase, a forma de organizar a fala etc. (BRASIL, 2006, p.25, grifos do autor).

Nesse caso e a partir dessa perspectiva, o livro didático extrapola em muito o seu papel de material instrucional (destinado apenas à sala de aula de aula e ao processo ensino- 
aprendizagem) para assumir o lugar da única literatura disponível a um grande número de crianças. Ou seja, o livro didático passa a se constituir não somente como um livro a ser utilizado na escola, mas sim como o, e único, livro dessas crianças.

Além disso, ao discutir especificamente seu papel em sala de aula, o MEC atribui ao livro didático a função de organizador do processo ensino-aprendizagem, selecionador do conteúdo e sua abordagem e propositor do método a ser posto em prática, assumindo muitas vezes o papel do professor (BRASIL, 2009).

Fica claro, portanto, que o MEC vê esse material como fundamental para formação geral de grande parcela da população e também como estruturante do cotidiano em sala de aula, inclusive substituindo o professor na tomada de decisão sobre questões inerentes à prática docente como, por exemplo, a escolha dos conteúdos "em detrimento de outros" ou o estabelecimento de "certo tipo de abordagem e tratamento". Nesse sentido a afirmação de Lajolo (1996) acima referida nos parece bastante atual, ou seja, o livro didático tem, a partir dessa perspectiva, o potencial de definir o que ensinar e como ensinar aquilo que deve ser ensinado.

Não é por acaso que uma das principais estratégias governamentais no campo das políticas educacionais está relacionada à avaliação, compra e distribuição de livros didáticos para as escolas públicas do país, por meio de programas específicos a esse fim.

\subsection{Os programas oficiais do livro didático no Brasil}

A preocupação com a compra e distribuição de material didático aos alunos das escolas públicas por parte do governo brasileiro não é nova. Tem sua origem em 1929, com a criação do Instituto Nacional do Livro (INL), primeiro órgão oficial com a função de legislar e regulamentar a política sobre o livro didático no Brasil (MANTOVANI, 2009; BRASIL, 2011). Políticas dessa natureza tiveram como seu marco institucional a publicação do decreto 1.006/38 de 1938 que criou a Comissão Nacional do Livro Didático (CNLD), a fim de estabelecer, pela primeira vez, as condições estruturais necessárias para a produção, importação e utilização do LD (HÖFLING, 2000; TOLENTINO NETO, 2003). Até 1983, os aspectos relativos à administração dessa política ficaram a cargo de diversos órgãos ${ }^{29}$ que

\footnotetext{
${ }^{29}$ A descrição detalhada das diversas estruturas governamentais responsáveis pela política do livro didático no Brasil, assim como suas funções pode ser vista em Höfling (2000); Tolentino Neto (2003) e Mantovani (2009).
} 
tinham como função principal assegurar a logística da compra e da distribuição desse material, tendo apenas "uma discreta preocupação" com a avaliação de sua qualidade. (TOLENTINO NETO, 2003, p.05).

Até 1993, quando o MEC assumiu como meta melhorar a qualidade do LD, tanto no que diz respeito às características físicas (qualidade da impressão, do papel etc.), quanto no que tange ao seu conteúdo, as ações de avaliação da qualidade dos livros distribuídos às escolas podem ser consideradas como pontuais e esporádicas, mesmo que nesse período fossem apontados erros graves nas coleções analisadas. (TOLENTINO NETO, 2003; MANTOVANI, 2009).

Como resultado dessa preocupação com a qualidade do livro, estabelecida por meio do Plano Decenal de Educação para Todo, que afirmava que

uma nova política do livro começa a ser formulada [...]. Além dos aspectos físicos do livro, passarão a ser assegurada a qualidade do seu conteúdo (fundamentação psicopedagógica, atualidade da informação em face do avanço do conhecimento na área, adequação ao destinatário, elementos ideológicos implícitos e explícitos) e sua capacidade de ajustamento a diferentes estratégias de ensino adotadas pelos professores (BRASIL, 1993, p.25),

e, especialmente, a partir do desenvolvimento do Programa Nacional do Livro Didático 1997 (PNLD 97), os livros didáticos comprados pelo governo passaram a ser avaliados por comissões de especialistas especialmente nomeadas para esse fim e, somente depois de aprovados, ficam disponíveis aos professores das escolas públicas para que possam ser escolhidos.

Dada a complexidade de interesses relacionados a esse mercado, considerado estratégico para o conjunto de editoras, esse primeiro processo de avaliação, ocorrido no bojo das ações dos PNLD 97, repercutiu fortemente no meio editorial e na mídia, principalmente em função da não aprovação de muitas das coleções que contavam com mercados bem estabelecidos. A esse respeito, Höfling (2000) aponta que

à época da divulgação de seus [do PNLD 97] resultados é possível ler com muita frequência matérias com títulos como "Editoras vão à justiça contra 0 MEC" (Folha de São Paulo, 21/05/96), "Autores de livros didáticos exigem lista do MEC" (Folha de São Paulo, 13/01/97), em jornais de grande circulação. Até mesmo pressões diretamente exercidas sobre pareceristas são relatadas pelos componentes das comissões de avaliação (p.168).

Nos dias de hoje, as ações governamentais de compra e distribuição de livros didáticos no Brasil estão articuladas por meio do Programa Nacional do Livro Didático (PNLD), que, 
em sua configuração atual, incorpora os anteriores Programa Nacional do Livro Didático para o Ensino Médio (PNLEM), criado em 2003, e o PNLD-EJA, destinado à educação de jovens e adultos, criado em 2011.

Tendo como objetivo final "prover as escolas públicas de ensino fundamental e médio com livros didáticos, dicionários e obras complementares de qualidade" (BRASIL, 2011), o PNLD é atualmente administrado e gerido pelo Fundo Nacional de Desenvolvimento da Educação (FNDE) que, desde 1997, é o responsável pela avaliação, compra e distribuição dos livros didáticos e dicionários para todos os alunos do Ensino Fundamental e Médio.

$\mathrm{Na}$ atual proposta, o PNLD se articula ao Programa Nacional Biblioteca na Escola (PNBE) no que o MEC denomina como "programas de material didático" que são

destinados a prover as escolas de educação básica pública das redes federal, estaduais, municipais e do Distrito Federal de obras didáticas, pedagógicas e literárias, bem como de outros materiais de apoio à prática educativa, de forma sistemática, regular e gratuita. (BRASIL, 2010c)

O PNLD, em função de seu volume de compra de livros, assim como de sua capacidade de distribuição para a rede pública de educação, pode ser considerado como uma das principais estratégias governamentais com vistas à qualificação do processo ensinoaprendizagem desenvolvido em sala de aula. A esse respeito Höfling (2000) afirma que programas dessa natureza devem ser entendidos como o cumprimento, por parte do Estado, de obrigações constitucionais de garantia de atendimento ao educando do material necessário ao seu processo escolar. Nesse sentido,

a natureza dos programas de assistência ao estudante se altera: de caráter assistencial, conjuntural, adquirem pelo preceito constitucional, caráter universalizante, obrigatório, destinados a todos aqueles que têm, igualmente, direito ao acesso à educação, pelo menos nos termos legais. (HÖFLING, 2000, p. 160).

Ou seja, todos aqueles que têm direito ao acesso à rede de escolas públicas isto é, todas as crianças e jovens em idade escolar e adultos, por meio da Educação de Jovens e Adultos (EJA), têm o direito ao recebimento de forma gratuita de livros didáticos de boa qualidade, aprovados pelo MEC.

É pertinente ressaltar que esse argumento constitucional é o que fundamenta o decreto n 7.084 , de 27 de janeiro de 2010 que regulamenta o PNLD (BRASIL, 2010c), que é assim apresentado no Guia do livro didático 2011: 
A recente publicação do Decreto $n^{\circ} 7.084$, de 27 de janeiro de 2010 e o texto do artigo 32 da Lei de Diretrizes e Bases - LDB dão respaldo à tão almejada qualidade da educação, que se aproxima, cada vez mais, do reconhecimento do papel da leitura independente para a ampliação do universo de referências dos alunos e, consequentemente, para a formação de indivíduos capazes de ler interpretar e reelaborar a realidade, por meio do acesso à informação [...]. Assim, o MEC distribui, atualmente: (I) no âmbito do Programa Nacional do Livro Didático - PNLD, livros didáticos a todos os alunos do ensino fundamental e médio; obras complementares às áreas do conhecimento para apoio ao processo de ensino e aprendizagem nos dois primeiros anos [...]; e dicionários; (II) no âmbito do Programa Nacional Biblioteca da Escola PNBE, livros de literatura para toda a educação básica, incluindo a Educação Infantil de 0 a 5 anos e a Educação de Jovens e Adultos; periódicos voltados para a formação e atualização dos professores [...] e finalmente, obras de cunho teórico-metodológico, dirigidas aos professores da rede pública. (BRASIL, 2010d, pp.07-08).

Os números do PNLD impressionam. O quadro abaixo apresenta o volume de compra de livros didáticos, dicionários e obras complementares destinados apenas ao Ensino Fundamental desde o PNLD 96 até o PNLD 2010. (figura 4).

\begin{tabular}{|c|c|c|c|c|c|c|c|}
\hline \multirow{2}{*}{$\begin{array}{c}\text { Ano de } \\
\text { aquisição }\end{array}$} & \multirow{2}{*}{$\begin{array}{c}\text { Ano } \\
\text { do } \\
\text { PNLD }\end{array}$} & \multirow{2}{*}{$\begin{array}{c}\text { Alunos } \\
\text { Beneficiados }\end{array}$} & \multirow{2}{*}{$\begin{array}{c}\text { Escolas } \\
\text { Beneficiadas }\end{array}$} & $\begin{array}{c}\text { Livros } \\
\text { Didáticos }\end{array}$ & Dicionários & $\begin{array}{c}\text { Obras } \\
\text { complementares }\end{array}$ & Total \\
\hline 1995 & 1996 & 29.423 .376 & 179.953 & 80.267 .799 & & & $\mathbf{8 0 . 2 6 7 . 7 9 9}$ \\
\hline 1996 & 1997 & 30.565 .229 & 179.133 & 84.732 .227 & & & $\mathbf{8 4 . 7 3 2 . 2 2 7}$ \\
\hline 1997 & 1998 & 22.920 .522 & 169.953 & 84.254 .768 & & & $\mathbf{8 4 . 2 5 4 . 7 6 8}$ \\
\hline 1998 & 1999 & 32.927 .703 & 169.949 & 109.159 .542 & & & $\mathbf{1 0 9 . 1 5 9 . 5 4 2}$ \\
\hline 1999 & 2000 & 33.459 .900 & 165.495 & 72.616 .050 & & & $\mathbf{7 2 . 6 1 6 . 0 5 0}$ \\
\hline 2000 & 2001 & 32.523 .494 & 163.368 & 110.052 .003 & 20.231 .351 & & $\mathbf{1 3 0 . 2 8 3 . 3 5 4}$ \\
\hline 2001 & 2002 & 31.942 .076 & 162.394 & 110.555 .832 & 10.140 .546 & & $\mathbf{1 2 0 . 6 9 5 . 5 9 2}$ \\
\hline 2002 & 2003 & 31.966 .753 & 159.228 & 52.496 .832 & 4.528 .041 & & $\mathbf{5 7 . 0 2 4 . 8 7 3}$ \\
\hline 2003 & 2004 & 31.911 .098 & 149.968 & 116.030 .521 & 3.349 .920 & & $\mathbf{1 1 9 . 3 8 0 . 4 4 1}$ \\
\hline 2004 & 2005 & 30.837 .947 & 149.968 & 111.189 .126 & & & $\mathbf{1 1 1 . 1 8 9 . 1 2 6}$ \\
\hline 2005 & 2006 & 29.864 .445 & 147.407 & 44.245 .296 & 6.403 .759 & & $\mathbf{5 0 . 6 4 9 . 0 5 5}$ \\
\hline 2006 & 2007 & 28.591 .571 & 144.943 & 102.521 .965 & & & $\mathbf{1 0 2 . 5 2 1 . 9 6 5}$ \\
\hline 2007 & 2008 & 31.140 .144 & 139.839 & 110.241 .724 & & & $\mathbf{1 1 0 . 2 4 1 . 7 2 4}$ \\
\hline 2008 & 2009 & 29.158 .208 & 136.781 & 60.542 .242 & & & $\mathbf{6 0 . 5 4 2 . 2 4 2}$ \\
\hline 2009 & 2010 & 28.968 .104 & 136.781 & 103.581 .176 & & 6.608 .597 & $\mathbf{1 1 0 . 1 8 9 . 7 7 3}$ \\
\hline
\end{tabular}

Figura 4: Volume de livros comprados, alunos e escolas beneficiadas, PNLD 1996-2010. (BRASIL, 2010e)

Para que um livro didático chegue às escolas é preciso que passe por um processo que vai desde sua elaboração (que deve respeitar regras definidas em edital público), passando pelo processo de avaliação por comissões de especialistas, escolha feita pelos professores, até sua distribuição nas escolas. Resumidamente, esse processo se dá da seguinte forma:

Inscrição das editoras: que deve ser feita de acordo com edital publicado no Diário Oficial da União, que determina as regras para a inscrição do livro e os prazos do Programa; 
Triagem/Avaliação: realizada pelo Instituto de Pesquisas Tecnológicas do Estado de São Paulo (IPT), a fim de conferir se os livros respondem às exigências técnicas do edital (qualidade da impressão, tipo de papel etc.);

Avaliação por especialistas: após a triagem, os livros são encaminhados para a Secretaria de Educação Básica do Ministério da Educação (SEB/MEC), responsável pela escolha das comissões de especialistas, geralmente vinculadas às universidades públicas, que têm a função de avaliar as obras conforme critérios publicados do edital. Além de avaliar o mérito dos LD, esses especialistas elaboram também as resenhas dos livros aprovados que farão parte os Guias do livro didático do respectivo programa;

Guia do livro didático: o FNDE elabora e disponibiliza para as escolas públicas os Guias do livro didático, que têm como função apresentar as obras a partir das resenhas avaliativas feitas pelas comissões de especialistas para que os professores e equipes escolares escolham os livros a serem utilizados;

Escolha: Os livros didáticos são escolhidos pelos professores e equipes escolares a partir das informações contidas nos Guias.

Pedido: os livros podem ser pedidos pelos professores ou equipes escolares, via internet, mediante senha enviada pelo FNDE ou por meio de formulário impresso, enviado juntamente com os Guias;

Aquisição: após a compilação dos pedidos feitos pelos professores, o FNDE inicia o processo de negociação com as editoras. A aquisição é realizada seguindo as normas legais de compras públicas, previstas na Lei 8.666/93 (lei que rege os processos licitatórios no âmbito das instituições públicas);

Produção: após a negociação, o FNDE firma o contrato e informa os quantitativos e as localidades de entrega para as editoras, que dão início à produção dos livros, feita sob a supervisão de técnicos do FNDE;

Distribuição: a distribuição é realizada diretamente pelas editoras às escolas, por meio de um contrato entre o FNDE e a Empresa Brasileira de Correios e Telégrafos (ECT). Essa etapa conta com o apoio do FNDE e das Secretarias Estaduais de Educação.

É importante destacar que os livros adquiridos pelo PLND, segundo as regras do edital, devem ser utilizados por três anos consecutivos e, portanto, devem ter o caráter nãoconsumível. As exceções são as "cartilhas de alfabetização", destinadas ao primeiro ano do 
Ensino Fundamental, e os livros de língua estrangeira (inglês e espanhol) para os anos finais do Ensino Fundamental ( $6^{\circ}$ ao $\left.9^{\circ}\right)$ e Ensino Médio, que são comprados anualmente ${ }^{30}$. Dada essa característica dos LD, há uma alternância temporal entre os programas destinados às séries iniciais e finais do Ensino Fundamental e para o Ensino Médio, para que "as compras integrais para alunos de $1^{\mathrm{a}}$ a $5^{\mathrm{a}}$ e de $6^{\mathrm{a}}$ a $9^{\mathrm{a}}$ anos possam ocorrem em exercícios alternados. Nos intervalos das compras integrais, são feitas reposições, por extravios ou perdas, e por complementações e por acréscimo de matrículas.” (BRASIL, 2011). Essa é a razão da grande oscilação dos números de compra de livros por ano apresentada no quadro anterior.

Segundo dados do FNDE, atualmente, no âmbito das ações do PLND 2012, voltado principalmente aos alunos do Ensino Médio, mas também à reposição das obras para os alunos do Ensino Fundamental, o orçamento total gira em torno de R $\$ 1,3$ bilhão, com a previsão de atingir cerca de 40 milhões de alunos. (BRASIL, 2012)

No presente trabalho foram analisadas todas as coleções de livros didáticos de Ciências para os anos iniciais do Ensino Fundamental ( $2^{\circ}$ ao $5^{\circ}$ anos) aprovadas pelo PNLD 2010. Ao expor a magnitude e importância desse programa, assim como o papel desempenhado (e esperado) pelo livro didático em sala de aula, procuramos apontar a pertinência e relevância da amostra analisada em relação aos objetivos propostos.

$\mathrm{Na}$ medida em que as coleções analisadas passaram por todo processo de avaliação realizado pelo MEC e, sendo aprovadas, estão pelo menos em princípio, de acordo com o que o ministério espera para esse material em sala de aula, são esses os livros, com suas concepções de saúde, com suas escolhas de certos conteúdos em detrimento de outros, com suas propostas de atividades e ênfases, que estão presentes nas salas de aula da maioria das escolas públicas do Brasil, sendo objeto de trabalho de milhares de professores e milhões de alunos.

\footnotetext{
${ }^{30}$ A justificativa para o caráter consumível dos livros de língua estrangeira está relacionada à tradição para o ensino dessas disciplinas, marcada por um grande número de atividades que pressupõem a escuta de áudios e preenchimento dos livros-texto, modelo esse tradicionalmente adotado pelos livros didáticos importados que são comumente usados para o ensino dessas línguas. Marca dessa característica pode ser vista nos editais que exigem que os livros submetidos ao PNLD sejam acompanhados de CD de áudio para a complementação das tarefas.
} 


\section{O PERCURSO METODOLÓGICO: O CAMINHO DA PESQUISA}

Em função dos objetivos da pesquisa optamos por uma análise documental de caráter exploratório, realizada por meio de uma abordagem quantitativa (na análise das frequências em que os indicadores propostos aparecem no conjunto das coleções) e uma qualitativa, na análise de cada obra individualmente. Para a seleção dos dados a serem analisados foram utilizados alguns pressupostos da análise de conteúdo (BARDIN, 2009). Para Quivy e Campenhoudt (2003), a partir desse método os dados acerca da "escolha dos termos utilizados pelo locutor, sua frequência e o seu modo de disposição, a construção do 'discurso' e o seu desenvolvimento são fontes de informações a partir das quais o investigador tenta construir um conhecimento." (p.226). Segundo esses autores essa abordagem é adequada para a investigação de materiais de diversas naturezas, incluindo "a análise de manuais escolares." (p. 230).

Em recente trabalho que apresenta um desenho metodológico para investigação de livros didáticos, Silva e Martins (2009) propõem a utilização do que definem como "marcas textuais" para a análise epistemológica do texto desses materiais. Segundo os autores essas "marcas" devem ser compreendidas como

indícios objetivos, no livro didático, da presença de uma determinada postura epistemológica. Ou seja, cada postura epistemológica utilizada, conscientemente ou não, deixará 'marcas', que poderão ser reconhecidas, mapeadas e classificadas. (SILVA e MARTINS, 2009, p. 182).

Os autores afirmam ainda que

em um texto didático, podemos encontrar "marcas textuais" como o uso de certas palavras, expressões, frases e referências explícitas a processos ou procedimentos metodológicos, dentre outras, que nos remetem a uma postura epistemológica do livro [...]. Essas marcas textuais podem ser identificadas no texto, nas citações, nos diagramas, nos exemplos, nas analogias, nos experimentos propostos, bem como nos exercícios. (SILVA e MARTINS, 2009, p. 183).

A partir dessa perspectiva, a análise aqui proposta buscou mapear e analisar essas "marcas" fornecidas pelos livros didáticos, por meio das quais fosse possível apreender quais as concepções de saúde que embasam a formulação e o desenvolvimento das unidades analisadas. Foram analisados apenas os textos escritos das coleções, não incorporando na análise os diagramas, esquemas, fotografias e demais figuras presentes nos livros. 
É importante ressaltar que em função da complexidade do objeto de estudo, especialmente quanto à questão de sua autoria e o caráter de miscelânea relacionado ao seu processo de produção, assim como já discutido anteriormente, a análise teve o cuidado de não atribuir ao autor (ou autores) dos livros analisados, mas sim às coleções, as visões de saúde aí encontradas.

\subsection{O universo da pesquisa: os livros didáticos do PNLD 2010}

Foram analisados os livros dos professores das coleções didáticas para as séries iniciais do Ensino Fundamental ( $2^{\circ}$ ao $5^{\circ}$ ano) aprovadas pelo Programa Nacional do Livro Didático 2010, avaliadas em 2009 e disponibilizadas para as escolas públicas a partir de 2010. Nessa versão do Programa, foram inscritas 33 coleções para esses anos, das quais 11 foram aprovadas. A totalidade das coleções aprovadas (44 volumes) constitui o universo da pesquisa. Tivemos acesso ao material enviado à comissão de avaliação, após consulta realizada junto ao MEC e com autorização e disponibilização das coleções por parte da coordenação da equipe de avaliação da referida versão do PNLD $^{31}$.

Justifica-se a escolha pelos livros destinados aos professores, na medida em que a análise levou em conta tanto as informações presentes nos textos destinados aos alunos, quanto às, orientações para os professores acerca do desenvolvimento das unidades presentes nos livros (orientações didáticas, respostas esperadas para as questões propostas, sugestões de atividades, objetivos pedagógicos e textos de apoio ao professor etc.). Além disso, esse material contém, invariavelmente, textos de "apresentação da coleção" onde estão descritos seus objetivos pedagógicos e apresentadas definições acerca dos pressupostos que embasam sua elaboração e estrutura (inclusive aqueles relacionados à saúde) que se constituíram como uma rica fonte de dados para a pesquisa.

Abaixo estão listadas as coleções aprovadas pelo PNLD 2010 para os anos iniciais do Ensino Fundamental que constituíram o universo dos livros analisados. ${ }^{32}$ (figura 5).

\footnotetext{
${ }^{31}$ A equipe de avaliação do PLND 2010 no que concerne aos livros didáticos de Ciências para os anos iniciais do Ensino Fundamental foi formada por especialistas vinculados à Universidade Federal de São Carlos (UFSCar), sob a coordenação do Prof. Nelson Studart.

${ }^{32}$ As referências completas de cada seleção estão no anexo1
} 


\begin{tabular}{|l|l|}
\hline \multicolumn{1}{|c|}{ Título da Coleção } & \multicolumn{1}{c|}{ Editora } \\
\hline Aprendendo Sempre - Ciências & Ática \\
\hline Asas Para Voar - Ciências & Ática \\
\hline Brasiliana - Ciências & Companhia Editora Nacional \\
\hline Porta Aberta - Ciências - Ed. Renovada & FTD \\
\hline Projeto Conviver - Ciências Naturais & Moderna \\
\hline Projeto Pitanguá & Moderna \\
\hline Ciências para Você & Positivo \\
\hline Descobrindo o Ambiente - Ciências & Saraiva \\
\hline A Escola é Nossa & Scipione \\
\hline Caracol - Ciências & Scipione \\
\hline Ler o Mundo - Ciências & Scipione \\
\hline
\end{tabular}

Figura 5 - coleções de livros didáticos de Ciências para os anos iniciais do Ensino Fundamental $\left(2^{\circ}\right.$ ao $\left.5^{\circ}\right)$ aprovadas pelo PNLD 2010

\subsection{As Categorias Analíticas}

Tendo como pano de fundo o referencial teórico referente à saúde apresentado em capítulo anterior, procuramos formular categorias que pudessem abarcar aspectos de diversas ordens no intuito de apreendermos o entendimento, ou entendimentos, acerca da saúde e do papel desempenhado pelos diversos determinantes no processo saúde-doença que basearam a construção das unidades analisadas, das obras individualmente e do conjunto dessas coleções.

Nesse sentido, as categorias não foram formuladas com o objetivo de classificar os trechos analisados ou elaborar uma "taxonomia" desses trechos ou da coleção, cabendo apenas uma "classificação" a cada um deles. Essa opção se justifica na medida em que acreditamos ser possível que em um mesmo trecho apareçam mais de uma concepção de saúde ou que as orientações acerca dos fatores que interferem na saúde, ou as orientações sobre medidas de proteção ou prevenção à saúde sejam de distintas naturezas, sem que isso se configure como um problema relacionado às categorias ou à análise. Entendemos que a análise da natureza dessas orientações e das ênfases de conteúdo nos é bastante pertinente, pois podem indicar pistas sobre as diversas visões relacionadas saúde, assim como sobre o papel que a educação (ou do ensino dos temas relacionados à saúde humana especificamente) pode desempenhar na melhoria das condições de saúde tanto individuais quanto coletivas.

Foram elaboradas as seguintes categorias analíticas:

Concepções de Saúde: dizem respeito ao entendimento acerca da saúde que embasa a elaboração das unidades, assim como as possíveis definições do termo que possam aparecer tanto no material dos alunos quanto no destinado aos professores. Como exposto 
anteriormente, a saúde classicamente pode ser entendida como: ausência de doença, bem ou valor, equilíbrio, direito, performance ou desempenho, bem-estar biopsicossocial (seguindo a definição da OMS);

Natureza dos determinantes: concerne aos fatores que estão expressos nos livros didáticos como aqueles que influenciam e determinam o processo saúde-doença. Esses fatores podem ser de naturezas bastante distintas: biológica; socioeconômica, ambientais, culturais e comportamentais (compreendidos aqui como aqueles relacionados aos comportamentos individuais). Essa análise levou em conta não só a menção a esses determinantes, mas também a ênfase e a importância atribuída a eles nas unidades analisadas;

Enfoque: está relacionado à dimensão e ao foco das orientações e discussões, podendo ser caracterizado como coletivo ou individual;

Natureza das Orientações: intrinsecamente relacionadas aos objetivos pedagógicos, as orientações presentes nas unidades foram analisadas a partir da seguinte perspectiva: prevenção de doença (cuidados e atitudes relacionados a uma doença ou agravo específico); promoção da saúde (sem relação direta com uma doença ou risco/agravo específico), que se subdivide em conservadora, que tem como foco a mudança de estilos de vida a partir de escolhas individuais e progressista, relativa a orientações que têm como proposta a discussão acerca das condições favoráveis e/ou desfavoráveis à saúde (ação social de caráter coletivo).

Ênfase dos conteúdos: diz respeito ao modo pelo qual os conteúdos relacionados à saúde são apresentados, assim como as ênfases dadas nessa apresentação: conteúdos relativos à descrição da doença (agente etiológico, sintomas, meios de transmissão, cuidados e atitudes de prevenção específicas); discussão e orientações acerca de "comportamentos saudáveis" (no âmbito do indivíduo); aspectos sociais de caráter amplo (econômicos, culturais, condições de moradia, renda, gêneros etc.); aspectos ambientais e, saúde como um direito.

\subsection{Coleta, tratamento dos dados e critérios de seleção das unidades}

Para a coleta dos dados foi realizada uma busca dos trechos de interesse em todos os volumes das onze coleções aprovadas pelo PNLD 2010, sendo incluídos para a análise aqueles que contemplassem um ou mais dos critérios abaixo descritos. Após essa etapa, os trechos selecionados foram fotocopiados compondo o material empírico da pesquisa. Para essa seleção, definimos os seguintes critérios não excludentes e complementares: 
- Unidade ou capítulo com referência explícita no título a assuntos relacionados à saúde.

Exemplo: Unidade 4 do volume para o $3^{\circ}$ ano da coleção "Porta Aberta", que tem como titulo "Água e Saúde";

- Trechos onde parece explicitamente no material para os alunos o termo "saúde", mesmo que em unidades ou capítulos que tratem de objetos não diretamente relacionados.

Exemplo: o trecho da unidade 17, para o $5^{\circ}$ ano da coleção "A Escola é Nossa", que tem como objeto a discussão sobre energia elétrica e apresenta recomendações e cuidados que devem ser tomados para evitar acidentes com a rede elétrica;

- Trechos em que não aparecem no material para os alunos tópicos relacionados à saúde, mas que os objetivos descritos manual do professor fazem alusão ao tema.

Exemplo: um dos objetivos da unidade 7 do volume para o $3^{\circ}$ ano da coleção "Projeto Pitanguá", que trata dos animais vertebrados e invertebrados se refere à "conscientização" sobre a prevenção de acidentes envolvendo animais peçonhentos;

- Unidades ou capítulos relativos ao corpo humano: anatomia e fisiologia.

Exemplo: capítulo intitulado "E gente, como é?" do volume para o $3^{\circ}$ ano da Coleção Ciências para você que, no contexto "reprodução dos animais" (unidade 3) discute as diferenças anatômicas entre homens e mulheres.

- $\quad$ Unidade ou capítulos relacionados à alimentação e nutrição.

Exemplo: unidade I do volume para o $3^{\circ}$ ano da Coleção Projeto Conviver intitulada "um, dois, feijão com arroz", que discute hábitos alimentares.

É importante ressaltar que cada trecho corresponde a um assunto ou tema específico. Em outras palavras, em uma unidade denominada "sistemas do corpo humano", por exemplo, os tópicos relacionados a cada um dos sistemas foram analisados como unidades específicas, ou ainda, em unidades que tratam diversos aspectos relacionados à saúde, cada um deles foi tratado separadamente.

Após a seleção dos trechos para análise, os dados de cada uma das unidades foram inseridos em um instrumento denominado como "matriz analítica" (anexo 2), a fim de sistematizar as informações de interesse relacionadas às categorias de análise, assim como 
propiciar uma visão geral sobre a coleção analisada. Nessa matriz, também foram feitas referências e observações sobre objetivos pedagógicos, as orientações didáticas e as propostas de atividades presentes nas, orientações para os professores para cada unidade analisada. Além disso, foram transcritos trechos dos livros que apontam e exemplificam a abordagem adotada e feitas observações pessoais acerca das ênfases e da lógica de construção do trecho, assim como de aspectos que chamaram a atenção na unidade analisada e na coleção como um todo.

Os dados obtidos a partir dessa sistematização foram inseridos em planilhas do Microsoft Excel ${ }^{\circledR}$ para a verificação das frequências e porcentagens constituintes da análise de caráter quantitativo.

\subsection{Os planos de análise}

Dados os objetivos da pesquisa, a análise se deu em três planos:

Análise por coleção: As 11 coleções foram analisadas tomadas individualmente. De caráter qualitativo, esse plano buscou apreender a visão, ou visões, acerca da saúde presentes em cada uma das coleções especificamente, assim como as características e marcas distintivas de cada uma delas;

Análise curricular (o currículo de saúde: temas e anos): A partir do mapeamento dos temas e assuntos relacionados à saúde para o conjunto das 11 coleções e dos momentos em que estes aparecem durante esse ciclo escolar, o objetivo foi o de compreender o percurso educacional relacionado à saúde proposto pelo conjunto desses livros didáticos. Ou seja, entendido o currículo como percurso educacional (FORQUIN, 1993), o objetivo foi o de apreender o "currículo da saúde" proposto por esses livros;

Análise geral: A partir da sistematização e análise dos dados de cada uma das unidades, o objetivo foi o de analisar as 11 coleções vistas como um todo, a fim de compreender quais as visões hegemônicas relacionadas à saúde, tomando como parâmetros as categorias analíticas propostas. A partir de uma abordagem quantitativa, o conjunto das coleções foi analisado em por meio das frequências e porcentagens que cada uma das possíveis abordagens apareceu no conjunto dos livros.

Com esses planos buscou-se contemplar tanto o conjunto como um todo, quanto cada uma das coleções vistas a partir de suas especificidades e singularidades. Os limites e alcances de cada um dos planos de análise estão descritos quando da apresentação dos resultados de cada um deles. 
Por fim, vale ressaltar que em função dos objetivos da pesquisa pelo fato de que tais coleções já passaram por uma avaliação criteriosa e reconhecida, que as credencia frente à comunidade escolar e acadêmica a estarem presentes nas salas de aula do país, não foi intenção realizar qualquer tipo de busca e avaliação de erros conceituais ou equívocos que, porventura, podem estar presentes nos livros, assim como atribuir qualquer tipo de juízo de valor às obras analisadas. 


\section{A SAÚDE NOS LIVROS DIDÁTICOS PARA OS ANOS INICIAIS DO ENSINO FUNDAMENTAL}

\subsection{Análise por Coleção}

A proposta de análise por coleção teve como objetivo compreender como os temas relacionados à saúde são abordados em cada uma das coleções, entendidas como um todo e independentemente do conjunto geral. Com o propósito de apreender as características gerais e "os matizes" relacionados à saúde de cada coleção essa análise, de caráter qualitativo, buscou investigar as marcas distintivas de cada uma das coleções quanto às concepções de saúde que são mais enfatizadas, à distribuição e à maneira pela qual os temas são desenvolvidos durante a coleção e aos objetivos pedagógicos relacionados à saúde. Buscou-se também investigar as ênfases dadas aos temas e conteúdos que chamaram a atenção, em função do seu destaque, em cada uma das coleções.

Além disso, partindo do pressuposto que as coleções analisadas foram avaliadas e aprovadas por especialistas da área e, por isso, têm o aval do Ministério da Educação para serem distribuídas às redes públicas de educação, vale dizer que não foi objetivo dessa pesquisa atribuir qualquer juízo de valor relacionado à qualidade de cada uma delas, assim como analisar possíveis erros conceituais ou equívocos presentes nas coleções, mesmo que esses possam ter sido detectados e apontados.

Na medida em que cada coleção é analisada independentemente, o limite que se coloca a essa abordagem é a impossibilidade de se obter uma visão geral do conjunto analisado, visão essa que permita traçar um panorama de como a saúde vem sendo tratada nos livros didáticos vistos em conjunto. Buscamos contemplar essa perspectiva a partir da análise geral, apresentada em item posterior.

Os textos analíticos de cada coleção, assim como os trechos dos livros que serão apresentados na análise geral para o conjunto das obras estão referenciados por meio de um número que corresponde ao código da coleção no Programa Nacional do Livro Didático 2010 (PNLD 2010). Além disso, pelo fato dos textos destinados aos alunos e aos professores serem numerados de forma distinta (e não sequencial) em um mesmo volume, os trechos apresentados que dizem respeito aos excertos retirados dos textos destinados aos professore serão referenciados com o acréscimo dessa informação. 


\subsection{As coleções}

\section{Coleção 611}

A coleção apresenta, desde seu início, a preocupação em tratar os temas de saúde a partir de uma perspectiva "positiva", no intuito de diferenciá-la da doença. Nesse sentido, a saúde é apresentada como bem-estar geral e associada, principalmente, às condições ambientais, às escolhas pessoais e aos aspectos relacionais ligados à convivência.

Em toda a coleção existem sessões denominadas "valorizando a saúde" que têm como objetivo, segundo as orientações didáticas para o professor, "informar sobre atitudes saudáveis". Além disso, nos volumes do segundo ao quarto anos existem unidades específicas denominadas "Ser Humano e Saúde", onde são tratados diversos temas relacionados à saúde e ao bem estar (alimentação, atividade física, saneamento, vacinas etc.). Tais temas são retomados em diversos momentos da coleção, a fim de aprofundar as questões tratadas anteriormente.

No volume para o $2^{\circ}$ ano, ao apresentar os conteúdos relacionados aos órgãos dos sentidos, a ênfase está no autoconhecimento e no reconhecimento de possíveis deficiências de visão e audição por parte dos alunos que podem, de certa maneira, comprometer seu rendimento escolar.

A unidade desta série que tem como foco específico a saúde é iniciada com uma pergunta sobre o entendimento dos alunos sobre o significado do termo. Como resposta, espera-se que os alunos respondam: "um completo bem-estar físico, mental e social, e não apenas a ausência de doenças" (vol. $2^{\circ}$ ano, p.163), alinhando-se, portanto, à definição da OMS de completo bem-estar.

Assim, define-se saúde como bem-estar individual e coletivo e enfatiza-se a aquisição de hábitos considerados saudáveis, tais como a alimentação equilibrada, a limpeza e higiene pessoal e ambiental, horas de sono, lazer e convivência.

A saúde está fortemente associada à perspectiva de estilo de vida e escolhas pessoais. Exemplo claro dessa perspectiva está nas orientações para os professores quando se afirma que

para alcançarmos o mais alto grau de saúde devemos nos responsabilizar por todas as nossas ações para evitarmos acidentes. Além disso, é importante pedir ajuda médica, não só quando estamos doentes, mas também para nos 
prevenirmos de doenças. Ir ao dentista regularmente ou tomar vacinas obrigatórias são exemplos de métodos preventivos. (vol. $2^{\circ}$ ano, p.75, orientações para os professores).

Há uma interessante separação, no volume do $3^{\circ}$ ano, entre tópicos relacionados à saúde, na perspectiva do direito e do bem-estar, dos conteúdos relacionados a doenças específicas (que têm como objetivo diferenciar as doenças transmissíveis das não transmissíveis), reforçando a diferenciação entre saúde e doença. Nessa unidade (intitulada "ser humano e saúde”) também se explicita a ideia de saúde como um direito,

segundo a declaração dos direitos humanos, todo o ser humano tem direito à saúde e ao bem-estar. O bem-estar físico e mental, além do bom relacionamento com outras pessoas e com o ambiente, contribui para que o ser humano tenha boa saúde. (vol. $3^{\circ}$ ano, p. 135).

A questão do saneamento básico é fortemente relacionada à saúde, tendo como premissa novamente a ideia de direito: “o saneamento básico é uma necessidade dos seres humanos que garante uma melhoria da qualidade de vida. No entanto, nem todas as pessoas têm acesso ao saneamento básico" (vol. $5^{\circ}$ ano, p.86).

Em muitos momentos da coleção, ao tratar de doenças especificas, é utilizado o modelo de descrição da doença, seus sintomas, agentes ou causas, prevenção e tratamento. A prevenção está baseada novamente nos aspectos comportamentais, mas em alguns momentos são apresentadas ações de caráter coletivo e social com vistas à mudança das condições desfavoráveis (campanhas de vacinação e contra a dengue, poluição ambiental etc.).

O tema da alimentação e nutrição é abordado durante toda a coleção e tem como pressuposto que a alimentação variada e equilibrada, associada à higiene na manipulação e armazenamento, é um fator importante para a saúde. Como objetivos a serem alcançados, enfatiza o reconhecimento, a aquisição e mudança de hábitos alimentares a partir de perspectiva individual. Não são tratados em toda a coleção os hábitos e costumes regionais e locais, assim como os alimentos disponíveis na região (aspectos sociais e culturais da alimentação). Nesse sentido, as orientações têm um caráter fortemente prescritivo e são descontextualizadas da realidade dos alunos.

As unidades que tratam da organização do corpo humano (órgãos e sistemas) - volume para o $5^{\circ}$ ano - apresentam um mesmo padrão de apresentação: além de conteúdos relativos à anatomia e fisiologia, existem tópicos denominados "doenças do sistema", onde são apresentadas algumas doenças ou agravos específicos, seguidos de temas relacionados à assistência e tratamento, com ênfase na tecnologia e equipamentos (marca-passo, hemodiálise, 
transplante e doação de órgãos). É importante ressaltar que, diferentemente dos demais e de certa forma surpreendentemente, esse modelo não é seguido apresentação do sistema reprodutor. Nessa unidade são descritos os principais órgãos e suas funções, assim como são apresentados conteúdos relativos à fecundação e gestação. Não existe a sessão "principais doenças" e assim não são apresentados os conteúdos acerca das DST, por exemplo, ou sobre métodos e atitudes para sua prevenção ou a discussão acerca da gravidez na adolescência.

É possível dizer, portanto, que, a despeito de assumir uma perspectiva de bem-estar biopsicossocial (alinhando-se à OMS) na sua apresentação, a coleção se caracteriza por abordar a saúde a partir de um enfoque que privilegia o indivíduo e como resultante de um conjunto de escolhas de caráter pessoal. Além disso, os determinantes sociais, quando aparecem, são pouco enfatizados em comparação aos primeiros, o que reforça a perspectiva individual.

O fato a ser ressaltado é a preocupação explicita, em muitos momentos da coleção, em diferenciar a saúde da doença (tal como apontado no exemplo acima, referente ao terceiro ano), assim como a ênfase dada à ideia de saúde como direito, principalmente relacionada às condições ambientais, mas não somente a elas.

\section{Coleção 632}

A coleção traz a ideia de estilo de vida como pressuposto básico relacionado à saúde e embasa o desenvolvimento de grande parte dos seus conteúdos a partir dessa perspectiva. Essa opção aparece claramente na apresentação da coleção, quando os autores afirmam que os alunos devem aprender "quanto o estilo de vida influi na saúde e desenvolvem [durante esse ciclo de escolarização] um trabalho que objetiva incentivar a adoção de um estilo de vida promotor de saúde" (vol. $2^{\circ}$ ano, p.46, orientações para os professores). Portanto, a coleção, ao adotar a perspectiva da promoção da saúde baseada na ideia de estilo de vida, denominada segundo Czeresnia (2009) como conservadora, enfatiza e prioriza aspectos de caráter individual e orientações baseadas nas escolhas pessoais. De fato, as questões de ordem coletiva, relacionadas à saúde não estão presentes. Aspectos como as condições de vida, de moradia, de acesso aos bens e serviços, assim como os relacionados à cultura e às especificidades locais não aparecem na coleção. 
A ideia de estilo de vida é trabalhada especialmente no volume para o quinto ano, onde há uma unidade específica que discute a relação entre escolhas pessoais e saúde, sem que sejam tratados os aspectos de caráter coletivo, acima apontados.

O volume para o $2^{\circ}$ ano possui uma unidade específica que trata dos hábitos relacionados à saúde, em especial à saúde bucal e àqueles ligados às diversas fases da vida. Espera-se, nessa unidade, que os alunos compreendam a importância dos hábitos de higiene e cuidados específicos (prevenção de acidentes e vacinas) para a manutenção da saúde. Nos conteúdos relacionados à vacinação, é proposta a verificação do calendário vacinal dos alunos (abordagem bastante comum no conjunto das coleções). Apresenta também os órgãos dos sentidos, na perspectiva do autoconhecimento. A visão e a audição são trabalhadas no contexto de "invenções" e é sugerida a visita de profissionais de saúde para o diagnóstico de possíveis deficiências.

Para o $3^{\circ}$ ano, ao tratar o tema das doenças transmitidas por animais, define-se como objetivo

desenvolver atitudes favoráveis à manutenção da saúde seja através de hábitos de higiene que ajudam a prevenir infestações por parasitas externos, seja através de cuidados com as vestimentas que ajudam a prevenir acidentes com serpentes e aranhas. (vol. $3^{\circ}$ ano, p.40).

Nesse volume é tratada a questão da alimentação no contexto "plantas", onde é assumido como objetivo questionar e favorecer a aquisição de hábitos alimentares saudáveis. Nessa discussão, não são abordados os aspectos culturais e socioeconômicos relacionados à alimentação, sendo essa entendida como uma escolha de ordem pessoal. No contexto “invenções”, a coleção apresenta um tópico específico relacionado à prevenção de acidentes com produtos químicos, sob a ótica da prevenção.

O tema da saúde é pouco abordado no volume para o quarto ano. Aparece de maneira mais incisiva na discussão de doenças que necessitam de alguma maneira da água (dengue, cólera, esquistossomose, febre amarela). Nesses assuntos, é adotado o modelo de descrição da doença, vetores ou agentes, sintomas, medidas de prevenção, modelo clássico de conhecimento sobre a doença. No contexto "energia" há a preocupação com os cuidados relacionados aos acidentes com eletricidade, onde são dadas diversas recomendações.

A questão da saúde aparece mais fortemente no volume para o quinto ano, onde a perspectiva do estilo de vida se explicita ao relacionar a saúde exclusivamente às escolhas pessoais, sejam essas ligadas à alimentação, atividades físicas e relacionamento interpessoal. 
Em uma unidade relativa à alimentação o mesmo volume traz as seguintes orientações especificas no início do módulo: "a unidade tem como objetivo discutir que atitudes responsáveis na escolha de uma alimentação adequada acabam refletindo mudanças no nosso estilo de vida e, consequentemente, em nossa qualidade de vida" (vol. $5^{\circ}$ ano, p.72). A unidade tem um caráter fortemente prescritivo, pois não há nenhuma discussão acerca dos determinantes culturais e socioeconômicos da alimentação. A alimentação é, portanto, vista apenas como uma questão de escolhas e não de possibilidades. Além disso, propõe-se uma "pirâmide de atividade física" (vol. $5^{\circ}$ ano, p 80) onde muitas das atividades propostas (ioga, aula em academia, nadar, dançar em festas) são recomendadas, especificando-se inclusive sua frequência semanal. Cabe perguntar, nesse caso, se essas atividades são possíveis para uma grande parcela da população que não tem acesso a esses bens e serviços, especialmente os alunos que frequentam a escola pública. Novamente, assim como ocorre com as recomendações alimentares, corre-se o risco de culpabilização do sujeito por sua situação de saúde, a partir de suas escolhas sem levar em conta se essas são possíveis ou pertinentes. (CASTIEL, 2007).

Outra unidade do mesmo volume trata especificamente da relação entre as escolhas pessoais e estilos de vida e a manutenção ou não da saúde, marca distintiva da coleção. Esta se inicia com a seguinte afirmação para os professores: "neste módulo trabalharemos com a ideia de que existem diferentes estilos de vida e que, se quisermos ser pessoas saudáveis, devemos escolher um estilo de vida que promova a saúde" (vol. $5^{\circ}$ ano, p. 82 ano, grifo nosso). Trabalha, portanto dentro da ideia de que ser saudável ou não é apenas uma questão de escolha individual. Apesar de apresentar o conceito de saúde baseado na definição de completo bem estar da OMS, associa esse bem-estar apenas às escolhas pessoais e não às condições de vida e aos determinantes de caráter coletivo: "é preciso mudar alguma coisa no seu dia-a-dia para você ser uma pessoa mais saudável?" (p. 87), denotando mais uma vez uma visão marcadamente individualista e individualizada da abordagem relacionada à promoção da saúde.

Apresenta ainda para o quinto ano, uma unidade que se propõe a discutir a relação entre corpo e sociedade. No início do módulo a coleção define que "serão exploradas algumas mudanças que vêm ocorrendo com o corpo humano e que podem ser relacionadas com mudanças na sociedade" (vol. $5^{\circ}$ ano, p. 124). No entanto, é trabalhada apenas a questão da obesidade que é, novamente, relacionada apenas a perspectiva das escolhas pessoais e estilo de vida. Perde-se, portanto a oportunidade de discutir padrões de beleza, busca do corpo 
perfeito, preconceitos, discriminações e distúrbios alimentares, por exemplo, que são questões especialmente importantes na faixa etária do ano (10-11 anos) quando essas pressões sociais ficam mais fortes. A proposta, por outro lado, pode favorecer esse tipo de atitude, na medida em que relaciona a obesidade apenas às escolhas feitas pelos alunos. Boa parte da unidade é voltada à discussão sobre a influência da propaganda no consumo de alimentos que podem causar obesidade e, novamente, perde-se a oportunidade de discutir os aspectos relacionados ao modelo de corpo perfeito que esses próprios meios exaltam e que influenciam profundamente as atitudes das crianças desta faixa etária e posteriores. Ou seja, o caminho inverso não é discutido e sim reforçado, apontando a responsabilidade pessoal como único fator da presença ou não da obesidade. Além disso, é proposta uma atividade de medição da circunferência abdominal bastante questionável, na medida em que poderá reforçar estigmas e constrangimentos relacionados à imagem corporal que as crianças têm de si mesmas e dos demais alunos.

Por fim, a apresentação das mudanças ocorridas na adolescência é mote para a discussão acerca da fecundação, aparelho reprodutor masculino e feminino e gravidez, onde há nas "lições complementares" a apresentação dos métodos contraceptivos (camisinha e pílula).

Em síntese, a coleção é bastante coerente em seu discurso sobre a saúde, na medida em que adota a perspectiva do estilo de vida como principal, senão único, determinante da situação de saúde das pessoas. Assim, seu principal objetivo é a aquisição de hábitos saudáveis e, principalmente, a orientação acerca das escolhas relacionadas às "atitudes saudáveis", tendo como referência apenas o individuo. Nesse sentido, todos os aspectos de caráter coletivo relacionados à saúde estão ausentes, assim como seus determinantes sociais mais amplos. Como aponta Buss (2000), nessa perspectiva são levados em conta apenas aqueles aspectos que o indivíduo tem governabilidade (mesmo que parcial), pois são esses os únicos passíveis de modificação a partir de escolhas individuais. Nesse sentido, é possível inferir que a coleção é, prioritariamente, voltada para certa faixa da população, ou seja, para aquela em que essas escolhas são possíveis.

\section{Coleção 651}

Já na apresentação da coleção é explicitado o entendimento acerca da saúde adotado, a partir da seguinte definição 
compreendemos a saúde como um estado de equilíbrio dinâmico do corpo, condicionado por fatores biológicos, psíquicos e sociais. Sob essa perspectiva, as atividades para o estudo do corpo envolvem o conhecimento de suas funções biológicas, psíquicas e sociais e dos fatores que nelas interferem: higiene pessoal e do ambiente, vacinação, hábitos alimentares saudáveis, necessidade de lazer, práticas esportivas, repouso adequado, vínculos afetivos e inserção social. (vol. $2^{\circ}$ ano, p.11, orientações para os professores).

Nesse sentido, há um alinhamento com a definição da Organização Mundial da Saúde, que preconiza o bem estar geral condicionado aos fatores internos e externos ao indivíduo. Também é explicitado o entendimento acerca do papel da família e da escola na promoção da saúde dos alunos quando afirmam que "para uma boa saúde, o corpo necessita de cuidados básicos [...]. Desde o brincar, como uma atividade de lazer, até o exercício físico, com o fim de manter a saúde do organismo, são cuidados que deverão ser estimulados pela escola e pela família." (vol. $2^{\circ}$ ano, p. 27 , orientações para os professores).

Durante toda a coleção existe uma forte preocupação com o cuidado intrafamiliar (puericultura e relações interpessoais) como fatores para o desenvolvimento saudável das crianças, ligados principalmente à dimensão afetiva. Há também a ênfase na percepção dos próprios hábitos e na aquisição de hábitos relacionados à higiene, aos cuidados pessoais e também à alimentação. Nesse contexto, aparecem, por exemplo, discussões acerca dos cuidados com os bebês, do aleitamento materno, das vacinas, das relações afetivas.

Vale ressaltar que nas discussões sobre alimentação sempre está presente a dimensão dos gastos com a compra dos alimentos, assim como com os problemas de desnutrição decorrentes da falta de acesso à alimentação de qualidade. Chama à atenção que essa dimensão perpassa todos os volumes da coleção, o que indica a preocupação com a desmistificação do custo com a alimentação considerada "saudável" e o incentivo ao consumo de alimentos disponíveis e possivelmente mais acessíveis aos alunos. Essa ênfase dada aos aspectos socioeconômicos relacionados à alimentação também aparece claramente na discussão que relaciona a desnutrição às condições econômicas e de acesso à alimentação de qualidade e suficiente, e não a sua produção. $O$ trecho a seguir explicita tal preocupação: "nem todas as pessoas têm uma alimentação variada e saudável. Pesquise por que isso acontece e indique algumas soluções." (vol. $2^{\circ}$ ano, p. 60). Nas orientações para os professores específicas a essa atividade é sugerido que o professor

explique a eles [os alunos] que muitas pessoas não se alimentam bem porque não têm condições econômicas de comprar comida (na quantidade e na variedade necessárias) ou porque comem em excesso determinados tipos de 
alimento [...]. A falta de informação, a pobreza e o desperdício são algumas das causas da má alimentação (vol. $2^{\circ}$ ano, p. 23, orientações para os professores).

No volume para o $3^{\circ}$ ano, há uma interessante discussão, partir do contexto "saneamento", sobre direito ao saneamento (água potável e tratamento dos esgotos) como fator de saúde, enfatizando aspectos da dimensão coletiva da saúde, tendo a ideia do direito e das condições de vida como foco da discussão. Estranhamente, no item seguinte, denominado “água e saúde” a ênfase está nas doenças. Ou seja, no item específico, cujo título explicita a relação entre as condições da água para o consumo e sua relação com a saúde, aparecem descrições das doenças, a partir do modelo clássico de sua apresentação: descrição da doença, sintomas, do agente (ciclo de vida), meios de transmissão, medidas de prevenção e cuidados específicos e tratamento. Assim, no momento específico de discussão da relação entre água e saúde (título da unidade) esta, a saúde, está associada e é discutida a partir da doença.

Nos conteúdos relativos à organização do corpo humano não há a preocupação excessiva em apresentar as estruturas e funções dos sistemas, à exceção do sistema musculoesquelético, onde a ênfase se dá na descrição dos ossos, nomes e funções. O sistema digestório é o mote para a discussão acerca da alimentação, incluindo a discussão sobre o custo de uma alimentação saudável e a falta de acesso à alimentação de qualidade (desnutrição e obesidade). Na apresentação do sistema reprodutor há a discussão dos cuidados com os bebês, aleitamento materno, e também tópicos relacionados às DST e Aids, apresentando dados epidemiológicos e uma discussão acerca do preconceito em relação à Aids.

Sinteticamente pode-se dizer que a coleção aborda a saúde a partir de seu conceito ampliado, tendo o cuidado (especialmente o que acontece no interior da família) com fator importante para sua manutenção e promoção. Discute e enfatiza, durante toda a coleção, os aspectos econômicos relacionados à alimentação e apresenta a noção de saúde como direito de maneira clara quando da discussão acerca das condições de saneamento básico e acesso à água potável. Além disso, aborda aspectos sociais relacionados à saúde quando da discussão acerca das doenças sexualmente transmissíveis, incluindo aspectos relacionados ao preconceito no caso da Aids. A coleção, portanto, adota a perspectiva do bem-estar e aborda a saúde levando em consideração seus aspectos coletivos de ordem social e econômica, assim como a relaciona com a ideia do cuidado, não só os de caráter biológico, mas também relacionado à dimensão afetiva e relacional. 


\section{Coleção 674}

No tocante à saúde, o pressuposto da coleção é claramente a ideia de prevenção, relacionada a um conjunto de hábitos. Essa perspectiva fica evidente quando, nos objetivos gerais da coleção, se explicita o entendimento acerca da saúde: “os alunos devem compreender a saúde como um conjunto de hábitos que favorece a manutenção do corpo e a prevenção de doenças" (vol. $2^{\circ}$ ano, p.05, orientações para os professores). Ou seja, a saúde é compreendida como "um conjunto de hábitos" e para a sua manutenção é necessário que esses hábitos sejam adquiridos ou modificados, tendo o ensino escolar um papel importante nesse processo. Tanto nas unidades que tratam explicitamente de temas relacionados à saúde (como, por exemplo, as que discutem hábitos de higiene ou alimentação e nutrição), quanto em dicas sobre cuidados específicos, mesmo que em contextos onde a saúde não é o objeto principal, a perspectiva de prevenção está presente. Outro exemplo claro dessa ênfase está exposto nas orientações para os professores no volume para o quinto ano, quando da apresentação do tema reprodução: "na saúde, a prevenção é a melhor maneira de se manter saudável” (vol. $5^{\circ}$ ano, p. 58 , orientações para os professores).

Em toda a coleção existem sessões denominadas "Questão de Saúde" que "relacionam o conteúdo apresentado à saúde humana por meio de textos ou atividades que propiciam a conscientização e o desenvolvimento de atitudes associadas à prevenção de doenças e à manutenção da saúde.” (vol. $2^{\circ}$ ano, p. 11, orientações para os professores), novamente explicitando o caráter preventivista da abordagem. A presença dessas sessões, de certa maneira, circunscreve a discussão dos temas a esse espaço, com exceção feita às unidades que têm como objeto principal a saúde.

Para o segundo ano, há uma unidade específica relacionada ao tema, onde são abordados assuntos relacionados à higiene pessoal, tendo por objetivo sua aquisição. $\mathrm{Na}$ discussão acerca dos órgãos dos sentidos, o objetivo é o de reconhecimentos dos próprios órgãos, assim como de suas funções. No contexto da "visão" são discutidos aspectos relacionados ao uso de óculos e seus cuidados, e é sugerida, nas orientações para os professores, a discussão sobre o método braile.

Para o terceiro ano, no contexto "seres vivos", são apresentados os conteúdos relacionados aos parasitas externos (piolhos, pulgas), aos animais peçonhentos e às doenças que têm insetos como vetores, especificamente a dengue, enfatizando as atitudes de prevenção e cuidados específicos relacionados a esses animais. 
Os temas relacionados aos sistemas do corpo humano se concentram nos volumes para o $4^{\circ}$ e $5^{\circ}$ anos. Para o $4^{\circ}$ ano, no contexto "energia nos seres vivos", os conteúdos relativos ao sistema digestório são apresentados a partir da apresentação da digestão como processo de obtenção de energia, com ênfase nos aspectos alimentares relacionados à descrição dos alimentos (funções), à "pirâmide alimentar" como modelo de alimentação saudável e na discussão acerca da análise dos próprios hábitos alimentares: "então, sua alimentação diária segue as recomendações dos nutricionistas?” (vol. $4^{\circ}$ ano, p. 126). É pertinente ressaltar que a apresentação dessa temática leva pouco em consideração os aspectos mais amplos relacionados à alimentação, tais como os socioeconômicos, de acesso à alimentação, os costumes e disponibilidades locais e regionais, assumindo, dessa forma, um caráter prescritivo e pouco relacionado ao cotidiano dos alunos. Ainda no mesmo contexto (energia nos seres vivos) é apresentado o aparelho circulatório, como meio de transporte da energia pelo corpo.

A ênfase da unidade que apresentam os conteúdos relacionados aos órgãos e sistemas, intitulada "Uma viagem pelo corpo", está no reconhecimento das principais estruturas e funções de cada um dos sistemas, assim como na relação entre eles para a manutenção da vida. Em alguns momentos são apresentados comportamentos considerados saudáveis relacionados aos sistemas que estão sendo apresentados. Exemplo dessa perspectiva está na sessão "questão de saúde" referente ao sistema nervoso, quando trata da necessidade do sono para a manutenção da saúde: "uma noite bem dormida faz a gente se sentir 'novo', mais atento, saudável e de bom humor [...]. De fato, as pessoas que dormem pouco ou mal ficam doentes com mais facilidade." (vol. $4^{\mathrm{o}}$ ano, p.177).

Para o $5^{\circ}$ ano, os temas relacionados à saúde são quase exclusivamente tratados no contexto "reprodução", que é o mote para a discussão acerca das mudanças ocorridas a partir da puberdade e dos cuidados de higiene necessários nesta fase. A apresentação do sistema reprodutor é bastante sintética (como a dos demais sistemas) e aparece vinculada à discussão sobre reprodução nos animais de maneira geral, sem que sejam abordadas questões relacionadas à sexualidade humana: “como nós, humanos, somos mamíferos, o homem transfere o sêmen do pênis para a vagina durante a relação sexual" (vol. $5^{\circ}$ ano, p. 205). As Doenças Sexualmente Transmissíveis (Aids, Sífilis e Hepatite C) são tratadas na sessão “questão de saúde", com ênfase no uso da camisinha como medida de prevenção "fácil, barata e eficaz" (vol. $5^{\circ}$ ano, p. 217).

Em síntese, pode-se dizer que a coleção enfatiza fortemente orientações de caráter preventivo, e essa prevenção se dá por meio da aquisição e mudança de hábitos. Sendo esse o 
seu foco principal, os conteúdos são desenvolvidos a partir de uma abordagem que imprime um caráter predominantemente individualizante e prescritivo às orientações. Aspectos relacionados aos determinantes sociais da saúde, assim como uma visão que extrapole o indivíduo em sua dimensão biológica não são abordados na coleção.

\section{Coleção 663}

A saúde aparece na apresentação da coleção como um dos "temas correlatos" aos diversos assuntos abordados nos quatro volumes da coleção (vol. $2^{\circ}$ ano, p.11, orientações para os professores). Apesar disso, são poucos os momentos em que os temas relacionados à saúde são tratados de maneira específica, sendo apresentados, na maioria das vezes, apenas como exemplos ou "dicas" descontextualizadas do restante da unidade. Vale dizer que esta é a coleção na qual foram selecionadas, a partir dos critérios estabelecidos para a análise geral, o menor número de unidades a serem analisadas. Para uma média geral de 26 trechos por coleção, foram selecionados, nesta coleção, apenas 16 .

Os temas relacionados à saúde estão bastante concentrados no volume para o $4^{\circ}$ ano, no contexto de desenvolvimento dos conteúdos relativos ao corpo humano (órgãos e sistemas). Nos demais volumes, a saúde aparece de forma esporádica, muito mais como “dicas" ou exemplos, do que como objeto da discussão.

A saúde é apresentada como um conjunto resultante de fatores como a higiene, a boa alimentação, associadas às atividades de lazer, onde é enfatizada sua dimensão relacional (relação com o outro) e o estilo de vida. Tal relação é explicitada na unidade "cuide da vida" ( $4^{\circ}$ ano) onde se afirma que "para manter a saúde, as pessoas precisam dormir bem, na hora certa, e ter um sono tranquilo. Precisam ter cuidados com a higiene dos alimentos [...]. Além disso, têm de cuidar da higiene do corpo." (vol. $4^{\circ}$ ano, p.121).

Essa unidade traz ainda uma discussão bastante questionável que aponta a importância do que denomina de "saúde mental", associando-a a um conjunto de sentimentos em relação aos outros e a si mesmo. Inicia-se a partir da seguinte afirmação: "na medida em que 'alimentamos' bem nossa saúde mental, com emoções positivas, bons pensamentos e momentos de lazer, melhor será nossa saúde física”, passando, a seguir, a definir o termo saúde mental como "ter pensamentos e sentimentos positivos sobre você mesmo e o mundo em que vive." (vol. $4^{\circ}$ ano, p.117). 
Tal relação entre a manutenção da saúde e os "pensamentos positivos" prossegue nas páginas seguintes ao afirmar que "para ter uma vida saudável não bastam apenas os cuidados com a higiene dos alimentos e do corpo, é importante também cuidar da saúde mental." (vol. $4^{\mathrm{o}}$ ano, p. 123).

Além da definição bastante questionável sobre saúde mental, há também nessa unidade um importante risco de culpabilização e responsabilização do indivíduo sobre sua saúde, na medida em que as orientações têm forte caráter individual e prescritivo. Ou seja, ao relacionar a saúde mental com um conjunto de pensamentos e sentimentos é possível inferir que os sentimentos "bons" ou "ruins" são apenas uma questão de escolha (consciente) do individuo, assim como a boa alimentação e os "bons hábitos” de saúde.

Em contrapartida, na mesma unidade são discutidos direitos humanos e de cidadania, assumindo a saúde um caráter coletivo e de mudança das condições desfavoráveis relacionadas, por exemplo, ao trabalho infantil e ao acesso ao saneamento básico:

nossa saúde depende muito da qualidade do ambiente em que vivemos. Precisamos cuidar muito bem dele [...]. Mas é também dever do governo cuidar da saúde e do bem estar da população. Cabe ao governo adotar medidas para evitar a poluição do ar, da água e do solo. [...] Assim como é direito das pessoas estudar, ter moradia e assistência médica é um direito também ter acesso ao saneamento básico. (vol.4 ano, p.128).

É interessante notar que na mesma unidade a saúde aparece como resultante de um conjunto de escolhas (com ênfase no indivíduo), mas também explicitamente como direito, quando relacionada à assistência e ao direito ao saneamento básico como condição de cidadania.

Os conteúdos relacionados à organização do corpo humano (órgãos e sistemas), desenvolvidos no quarto ano, são apresentados com forte caráter descritivo, onde a ênfase se dá nos nomes dos órgãos e principais funções. Exemplo claro desse caráter é a discussão sobre o sistema reprodutor e fecundação humana, onde há apenas descrição do funcionamento dos órgãos (anatomia e fisiologia). O tema é tratado com a utilização de terminologia técnica e nomenclatura específica:

numa relação sexual entre um homem e uma mulher, o pênis penetra no canal vaginal e pode eliminar esperma no corpo feminino. Os espermatozoides, então, alcançam o útero e depois as tubas uterinas. Se encontrarem um óvulo, pode haver a fecundação. (vol. $4^{\circ}$ ano, p.111). 
Não são tratados, por exemplo, temas como cuidados específicos de higiene, mudanças corporais e questões acerca da sexualidade, atitudes de prevenção contra as DST, gravidez indesejada na adolescência, aspectos afetivos, dentre outros. Nesse sentido, parece procurar abordar o assunto de forma a criar certa "distância técnica", em função das questões e discussões que podem suscitar, que nem sempre são fáceis de serem trabalhadas em sala de aula, especialmente na faixa etária em questão.

Nesse mesmo contexto (órgãos e sistemas), o sistema digestório é mote para a discussão acerca da alimentação, baseada em uma extensa descrição dos alimentos com ênfase na nomenclatura, fontes e funções dos nutrientes. Nessa abordagem, assim como em outros momentos em que a questão da alimentação é tratada durante a coleção, não são levados em conta os hábitos e costumes regionais e a disponibilidade de alimentos, os custos e sua distribuição. Ou seja, os aspectos culturais, sociais e econômicos ligados à alimentação e nutrição não são tratados.

Resumidamente, é possível dizer que, apesar de ser apresentada como "tema correlato" os temas relacionados à saúde aparecem pouco durante os quatro anos da coleção, sendo desenvolvidos de maneira concentrada em um dos anos ( $4^{\circ}$ ano), a partir da apresentação das estruturas do corpo humano. Além disso, a coleção aborda a saúde a partir da premissa de que é a resultante de escolhas pessoais (hábitos de higiene, alimentação, cuidados específicos), associada às condições ambientais (apenas quando relacionada às condições de saneamento básico) e à qualidade das relações interpessoais (quando, por exemplo, discute o que define como "saúde mental"). Adota, portanto, a perspectiva do estilo de vida, privilegiando sua dimensão individual. Coerentemente, deixa de abordar os fatores de caráter social, cultural e econômico em temas que são intrinsecamente relacionados a eles, tais como à alimentação e nutrição, dentre outros.

\section{Coleção 679}

A coleção adota claramente a conceito ampliado de saúde como delineador do desenvolvimento dos conteúdos relativos ao tema. Além disso, apresenta como marca distintiva a ideia de saúde como direito, ideia essa que perpassa todas as discussões nos quatro volumes e é objeto central de uma extensa unidade, que ocupa grande parte do volume para o segundo ano. 
Essa unidade, denominada "Eu quero a minha saúde", é subdividida em seis grandes temas: "saúde como direito", "alimentação", "higiene", "vacinas", "acidentes", "moradia" e "brincar e receber carinho" e adota como pano de fundo para as discussões os contextos sociais em que os alunos estão inseridos. Para o desenvolvimento do conteúdo, parte da ideia da saúde como direito de todos e adota explicitamente o conceito ampliado de saúde, entendida como a situação resultante de fatores de ordem biológica, social, econômica e cultural. Entre seus objetivos pretende-se que os alunos sejam capazes de

compreender a saúde como um direito e uma responsabilidade pessoal e coletiva; compreender a saúde em seu sentido mais amplo, aceito pela OMS, que se refere a ela como um estado de bem-estar físico, mental e social e não meramente como ausência de doença; valorizar atitudes e comportamentos favoráveis à saúde. (vol. $2^{\circ}$ ano pp.50-51, orientações para os professores).

Como exemplo dessa perspectiva, a discussão acerca da alimentação privilegia a reflexão sobre os alimentos disponíveis e culturalmente valorizados na região e sua relação com a alimentação considerada saudável. Nas orientações específicas para o desenvolvimento desse tema, o professor é orientado da seguinte maneira: "em razão das diferenças socioeconômicas e culturais no Brasil, [o desenvolvimento do tema da nutrição] impõe um olhar atento para as necessidades e os hábitos da comunidade em que a escola está inserida." (vol. $2^{\circ}$ ano, p.53, orientações para os professores).

Os conteúdos acerca da higiene são mote para a discussão sobre as condições de saneamento básico e condições de vida. Nas orientações para os professores há a referência acerca das condições de saneamento básico relacionadas ao contexto em que a escola está inserida, assim como dados epidemiológicos que relacionam taxas de mortalidade infantil às condições de saneamento. Além disso, propõe a organização popular para a melhoria das condições existentes: "é importante que, mesmo diante de condições ruins de saneamento básico na comunidade escolar, a comunidade reconheça a importância desses comportamentos e busque formas de torná-los possíveis." (vol. $2^{\circ}$ ano, p.58, orientações para os professores.). São discutidas, nesse contexto, as condições de moradia e o trabalho infantil como fatores intervenientes das situações de saúde: "Morar bem é um direito. A moradia pode ajudar as pessoas a terem saúde?" (vol. $2^{\circ}$ ano, p. 133) ou “em algumas regiões do Brasil, as crianças perdem a saúde e arriscam a vida no duro trabalho de fazer carvão.” (p. 115), são trechos que explicitam a preocupação com o desenvolvimento de conteúdos dessa natureza.

Nesse sentido, chama à atenção a ênfase dada à dimensão coletiva da saúde, assim como a preocupação em desenvolver os conteúdos que procuram relacionar a saúde com as 
condições sociais e econômicas e culturais que a influenciam como tônica da unidade. Além disso, é clara a preocupação em relacionar a discussão ao cotidiano dos alunos e as especificidades locorregionais.

Mesmo adotando essa perspectiva e esse conceito ampliado de saúde, em alguns momentos há a clara compreensão da saúde como resultante de escolhas pessoais: "colocar a criança em contato com seu Cartão de Vacinação é um passo em direção à compreensão de que a saúde é uma responsabilidade e uma construção que cada indivíduo deve assumir" (vol. $2^{\circ}$ ano, p. 59, orientações para os professores) ou "em cada atitude que a gente toma, é bom pensar: eu estou buscando a minha saúde? A saúde depende de outras pessoas que cuidam de nós e que são responsáveis por nós, mas também depende da gente.” (vol. $2^{\circ}$ ano, p.118).

É importante ressaltar que, nessa responsabilização sobre a própria saúde, aparecem claramente os papéis da criança e do adulto responsável por seus cuidados: “para combater os piolhos, alguém da sua família deve estar sempre de olho na sua cabeça" (vol. $2^{\circ}$ ano, p.102) ou "se acontecer um acidente com você ou outra criança, procure logo um adulto e peça ajuda." (vol. $2^{\circ}$ ano, p.109).

No volume para o terceiro ano, ao discutir as fases da vida e os cuidados necessários a cada uma delas há, nas orientações para os professores, referências sobre o "teste do pezinho" como direito de todas as crianças (vol. $3^{\circ}$ ano p. 65, orientações para os professores). Traz também a discussão acerca do trabalho infantil e sua relação com as condições de saúde e a "ausência da infância". Ainda nessas orientações, apresenta-se a discussão sobre o direito à saúde e aos cuidados necessários na infância, assim como definidos no Estatuto da Criança e do Adolescente (ECA) e referências ao Sistema Único de Saúde, como meio de assistência à saúde pública e gratuita. (vol. $3^{\circ}$ ano, pp. 68-69, orientações para os professores).

Os conteúdos relacionados à água e ao tratamento de esgoto são tratados no volume para o quarto ano, sob a premissa de que essas condições são determinantes da saúde, enfatizando as medidas de prevenção às doenças de veiculação hídrica e o tratamento de esgotos como direito de todos. No mesmo volume, no contexto "energia", é abordado o tema da obesidade infantil, tratada como um desequilíbrio entre a ingestão e o consumo de energia pelo corpo. São discutidas, nas orientações para os professores, medidas de caráter individual e coletivo para o enfrentamento dessa situação (regulamentação das cantinas escolares, incentivo às atividades físicas, dentre outros). Aponta ainda os distúrbios psicossociais relacionados aos estigmas e preconceitos como um dos principais problemas decorrentes da obesidade infantil. É interessante notar que é essa é a única coleção que aborda os problemas 
de ordem psicossociais, e não os de caráter fisiológico ou a "prevenção de doenças no futuro", como os principais relacionados à obesidade infantil.

Os conteúdos relativos à organização do corpo humano (órgãos e sistemas) são trabalhados no volume para o quinto ano. Nesse contexto, a apresentação do sistema digestório é mote para a discussão sobre saúde bucal, tendo como objetivo o autoconhecimento e a consolidação dos hábitos de higiene. Nas orientações para os professores referentes a essa atividade, fica clara a perspectiva adotada na coleção referente ao direito à saúde:

a saúde bucal deve ser vista como um direito ainda não conquistado por toda a população. $\mathrm{O}$ maior entrave ao acesso às condições necessárias para a saúde bucal é a pobreza que atinge grande parte da população brasileira. (vol. $5^{\circ}$ ano, p.33, orientações para os professores).

Esse volume apresenta ainda uma unidade que trata do desequilíbrio ambiental, na qual fica explicitada a ideia de saúde como equilíbrio e das doenças como desequilíbrios internos ou relacionados ao ambiente:

as doenças indicam um desequilíbrio em nosso corpo ou entre ele e os outros componentes do ambiente [...]. O uso de vacinas e boas condições de moradia, saneamento, trabalho, alimentação e convivência social são importantes para nos mantermos em equilíbrio e livres das doenças. (vol. $5^{\circ}$ ano, p.163).

Nesse contexto, são apresentadas algumas doenças transmitidas por mosquitos (malária, febre amarela e dengue) que, segundo os conteúdos apresentados, recrudesceram em função de desequilíbrios ambientais. A apresentação dessas doenças ocupa grande parte da unidade que está estruturada a partir do modelo que privilegia o conhecimento sobre a doença: descrição da doença, agente etiológico, sintomas, meios de transmissão e prevenção.

Ainda nessa unidade, é discutida a alimentação como um dos fatores de saúde, seguindo a ideia de equilíbrio, e são enfatizados conteúdos que dizem respeito à classificação e função dos alimentos. Para esse tópico, as orientações deixam clara a preocupação com os contextos dos alunos, assim como com os aspectos culturais da alimentação:

a discussão sobre a alimentação equilibrada deve ser feita de maneira contextualizada e levando em consideração as características regionais, tanto em relação à disponibilidade de alimentos quanto em relação aos hábitos e costumes das famílias, o que inclui preferências alimentares e modos típicos de preparar alimentos. (vol. $5^{\circ}$ ano, p. 91, orientações para os professores). 
$\mathrm{Na}$ unidade referente às mudanças ocorridas na puberdade, são abordados assuntos relacionados aos aspectos biológicos (descrição dos sistemas reprodutores, mudanças físicas) e comportamentais. No entanto, a discussão sobre a sexualidade fica restrita às sugestões feitas nas orientações para os professores. O tema da Aids aparece como único relacionado às DST. Nesse contexto, ainda são discutidas algumas práticas danosas à saúde em função da busca do corpo perfeito (regimes alimentares, o uso de medicamentos, atividades físicas sem supervisão etc.).

Em síntese, a coleção aborda o tema da saúde sob a perspectiva do direito e sempre a partir de seu conceito ampliado, que abrange os aspectos de ordem social, econômica e cultural. Essa perspectiva é apontada de maneira marcante logo no início da coleção, quando apresenta uma extensa unidade específica em que são abordados temas de diversas ordens (alimentação, moradia, vacinação, direito ao brincar etc.). Chama a atenção o fato de que parece existir a intenção de articular esses determinantes em quaisquer que sejam os temas abordados e em muitos momentos da coleção. Assim, há uma abordagem que se distingue das demais coleções justamente por colocar no foco de atenção dos alunos (e também do professor) os determinantes mais amplos e de caráter coletivo da saúde, relacionando-os aos temas específicos trabalhados a partir da compreensão da saúde como um direito.

\section{Coleção 675}

Em sua apresentação, a coleção define como um dos objetivos do ensino de ciências para o primeiro ciclo do Ensino Fundamental a criação de situações para que a criança "admita a dimensão pessoal, social e ambiental da saúde, considerando-a um projeto a ser permanentemente desenvolvido individual e coletivamente" (vol. $2^{\circ}$ ano, p.05, orientações para os professores). Nessa definição, aparecem dois aspectos importantes: o caráter coletivo da saúde e a incorporação de aspectos ambientais e sociais, somados aos de caráter pessoal, na determinação da situação de saúde das pessoas. As orientações voltadas à prevenção, a partir da ideia de que a escola é um local privilegiado para a aquisição de hábitos, dão "o tom" da coleção. Exemplos claros dessa tendência podem ser vistos nas orientações específicas sobre saúde bucal (vols. do $2^{\circ}$ e do $5^{\circ}$ ano) onde é explicitado da seguinte forma o entendimento do papel da escola relacionado à saúde: "Lembre-se da contribuição fundamental da escola na aquisição de hábitos de higiene" (vol. $2^{\circ}$ ano, p. 59, orientações para os professores e vol. $5^{\circ}$ ano, p. 68, orientações para os professores). 
Somada a essa preocupação com o desenvolvimento de hábitos, a relação entre os aspectos do ambiente e a saúde e, em muitos momentos, a perspectiva da saúde como um direito são claramente as principais marcas coleção.

Para o segundo ano, os conteúdos relativos aos órgãos dos sentidos são apresentados com ênfase na descrição de suas funções e nos cuidados necessários para cada estrutura, adotando uma perspectiva relacionada ao autoconhecimento e à aquisição de hábitos de higiene. O tema da alimentação é relacionado tanto aos aspectos individuais (como preferências e gostos), quanto aos aspectos relacionados aos costumes regionais e ao acesso a certos tipos de alimentos. Na discussão sobre o ambiente há uma atividade que relaciona o desperdício de alimentos com a fome e a desnutrição, onde é explicitado o direito à alimentação saudável, tema esse retomado no quinto ano, a partir da discussão sobre o sistema digestório.

Coerentemente com o título da coleção (Descobrindo o Ambiente), o tema da saúde é, em muitos momentos, relacionado aos aspectos ambientais. No terceiro ano, por exemplo, essa relação é explorada por meio do desenvolvimento de conteúdos como o da poluição atmosférica (no contexto "ar") ou na discussão acerca da água. Nesse último tópico, são enfatizadas algumas doenças de veiculação hídrica, com especial atenção à esquistossomose, que é apresentada a partir de uma abordagem característica do modelo biomédico, marcada pela descrição do agente e seu ciclo e das medidas de prevenção (inclusive com uma figura clássica que representa o ciclo do Schistosoma mansoni e o papel dos hospedeiros). Nas orientações para os professores, específicas dessa unidade, são abordados outros aspectos que abarcam questões de ordem social e culturais que poderiam dar maior significado à discussão, assim como agregar aspectos importantes para a compreensão dos condicionantes do processo saúde-doença:

não pretendemos que a criança memorize ou descreva o ciclo representado na ilustração, mas que interprete o diagrama para relacionar a prevenção de doença com a existência de saneamento básico, com o tratamento do indivíduo doente, com os hábitos culturais, a informação e a educação das pessoas. (vol. $3^{\circ}$ ano, p.94, orientações para os professores).

Nesse sentido, vale perguntar o porquê desses temas serem tratados apenas nas orientações e não no material dos alunos? Parece-nos que ao apresentar essa discussão apenas no material destinado ao professor, sem que haja qualquer tipo de menção a elas no material dos alunos, perde-se a oportunidade de discutir mais enfaticamente o papel dos determinantes 
coletivos (tais como os citados nas orientações) na constituição das situações de saúde vividas pelas pessoas, tomando, por exemplo, o ciclo representado na ilustração.

Ainda nesse tema, são apresentados os conteúdos relacionados ao tratamento da água e sua importância para a saúde. Nas orientações para os professores enfatiza-se a questão do direito à água de qualidade para todas as pessoas, assim como a necessidade da criação de mecanismos de reivindicação e mobilização social para esse fim:

a água é um bem indispensável à vida, e sua qualidade é fundamental para a saúde das populações. Por isso deve ser distribuída igualmente para todos [...]. As pessoas que não recebem água tratada precisam aprender o que fazer, individualmente, para cuidar da água de que dispõem. Devem, também, se organizar para lutar, coletivamente, pelo acesso aos serviços de saneamento básico. (vol. $3^{\circ}$ ano, p. 97 , orientações para os professores).

O direito à saúde aparece aqui vinculado ao direito ao acesso ao saneamento básico, assim como em outras coleções, e relacionado novamente aos seus condicionantes ambientais. É interessante ressaltar nessa orientação a preocupação com as soluções de caráter individual (soluções caseiras), assim como as de caráter coletivo, como a reivindicação coletiva por melhores condições de saneamento básico, que podem ser vistas como características de certa vertente da promoção da saúde, caracterizada por Czeresnia (2009) como progressista.

Para o quarto ano, os conteúdos relacionados à saúde aparecem apenas na discussão sobre os seres vivos, com a apresentação de algumas doenças transmitidas por microrganismos. Nesse contexto, são apresentadas algumas doenças infectocontagiosas, e a descoberta, feita por Pasteur, da relação entre a presença de certos microrganismos e a configuração de alguns estados patológicos. O caráter preventivista das orientações aparece novamente ligado às condições ambientais e à aquisição de hábitos: “A vida em um ambiente saudável, uma alimentação variada e os cuidados com a higiene nos protegem contra as doenças infecciosas" (vol. $4^{\mathrm{o}}$ ano, p.65). Esse contexto também serve como mote para a discussão sobre o uso de antibióticos e vacinação, tendo como um de seus objetivos a verificação, por parte do professor, do calendário de vacinal dos alunos. Vale apontar que esse último objetivo é algo bastante comum nas coleções analisadas.

Para o quinto ano, são apresentados os conteúdos relativos aos sistemas do corpo humano, tendo como principal aspecto a descrição dos sistemas, seus órgãos e principais funções. Quando da apresentação do sistema reprodutor, há a discussão sobre o papel social dos gêneros, assim como sobre a gravidez precoce. O tema da sexualidade é sugerido apenas nas orientações para os professores a ser trabalhado "integrado a um projeto de educação 
sexual da escola, e que esse projeto seja construído também com a participação dos pais." (vol. $5^{\circ}$ ano, p.54, orientações para os professores). Por outro lado, não há referência sobre a sexualidade humana no material dos alunos.

O sistema digestório é mote para a discussão sobre saúde bucal, onde são enfatizados hábitos de higiene e aspectos relacionados à alimentação. Esse último assunto tem como um de seus objetivos "a compreensão de que todos os brasileiros têm direito a uma alimentação saudável" (vol. $5^{\circ}$ ano, p. 62, orientações para os professores), explicitando a ideia do acesso à alimentação de qualidade como condição de saúde, sob a perspectiva do direito. Ainda nesse tópico, a discussão sobre os hábitos alimentares não se restringe à natureza dos alimentos, mas também à maneira como é feita a alimentação e ao ambiente onde são realizadas as refeições: "Os cuidados de higiene, a aparência, o cheiro e o sabor do alimento, seu comportamento ao fazer as refeições e o ambiente em que elas acontecem também são importantes para a saúde." (vol. $5^{\circ}$ ano, p. 56). São discutidos também seus aspectos socioeconômicos e culturais, assim como o direito à alimentação saudável como inerente à constituição brasileira: "apesar do que diz a constituição [artigo 227, citado anteriormente], muitas crianças brasileiras passam fome. Por que isso acontece?” (vol. $5^{\circ}$ ano, p.59). Nas suas orientações específicas, há a preocupação em apontar as dificuldades de se trabalhar com o tema levando-se em conta os aspectos acima descritos: "Há uma estreita relação entre alimentação e a situação econômica, hábitos culturais e recursos do ambiente, de modo que é difícil prescrever uma dieta universalmente adequada." (vol. $5^{\circ}$ ano, p. 74, orientações para os professores).

Finalizando essa unidade, são apontados os aspectos relacionados à desigualdade social como determinantes de saúde, reforçando a ideia de direito à saúde:

muitas famílias não têm como oferecer às suas crianças uma alimentação saudável porque não têm acesso ao emprego ou não recebem o suficiente para suprir suas necessidades básicas. Esse problema se deve à falta de equidade na distribuição da riqueza [...]. Cabe, então, à sociedade e ao Estado fazer valer o que estabelece a constituição. (vol. $5^{\circ}$ ano, p. 74, orientações para os professores).

Em síntese, a coleção tem como norte a relação entre saúde e ambiente e a discussão e aquisição de hábitos (de higiene e alimentares, principalmente) como um dos objetivos. Em muitos momentos aborda aspectos relacionados ao direito à saúde, principalmente quando estabelece a relação desta com o acesso ao saneamento básico e à alimentação de qualidade. Além disso, procura abordar os temas relacionados à saúde de maneira a contemplar tanto sua 
dimensão individual, quanto coletiva, na perspectiva de melhoria das condições desfavoráveis e deletérias à saúde.

Alguns aspectos importantes aparecem apenas como sugestões nas orientações para os professores, sem referência no material dos alunos como, por exemplo, a discussão acerca das doenças de veiculação hídrica ( $3^{\circ}$ ano) ou a discussão sobre sexualidade e DST, no quinto ano. Nesse caso, parece haver a perda de oportunidades importantes de dar maior ênfase a esses aspectos, assim como relacionar o tema da saúde aos contextos nos quais os alunos e suas famílias estão inseridos, qualificando e atribuindo maior significado às discussões propostas.

\section{Coleção 793}

Adotando a estrutura proposta pelos PCN para o ensino de ciências, a coleção se organiza a partir dos eixos temáticos: "ambiente", "ser humano e saúde", "recursos tecnológicos" e "noções de Terra e Universo". Em seu texto de apresentação, a coleção se posiciona, no que diz respeito à saúde, a partir da seguinte afirmação:

entre os inúmeros fatores que determinam as condições de saúde e qualidade de vida incluem-se condicionantes biológicos, os meios físico, socioeconômico e cultural, que expressam os níveis de ocupação e renda, o acesso à educação e ao lazer, os hábitos e formas de relacionamentos e o acesso aos serviços necessários à promoção da saúde. (vol. $2^{\circ}$ ano, p.12, orientações para os professores),

adotando, desse modo, a compreensão da saúde como resultante de fatores de diversas naturezas, a partir de uma visão ampliada do processo saúde-doença.

No entanto, em uma orientação específica, relacionada a uma atividade do mesmo volume, há o seguinte texto referente aos cuidados com a saúde das crianças pequenas: "os principais cuidados com a saúde das crianças podem ser resumidos em três grandes itens: higiene, alimentação e vacinação." (vol. $2^{\circ}$ ano, p. 38, orientações para os professores). Assim, todos os aspectos que dizem respeito à criação de um ambiente favorável ao desenvolvimento da criança, ao seu bem-estar geral, ao lazer, às condições de vida e moradia, dentre outros, que são fundamentais na primeira definição, não são levados em conta. Há, portanto, uma grande distância e importante incoerência entre a definição de saúde explicitada na apresentação da coleção e as orientações acima descritas, na medida nesta orientação a saúde está reduzida apenas aos seus aspectos biológicos (higiene, alimentação e vacinas). Mesmo que existam referências quanto à necessidade de "uma efetiva higienização do 
ambiente em que vivemos e onde as crianças brincam" (vol. $2^{\circ}$ ano, p. 38, orientações para os professores), o objetivo relacionado à saúde está ligado à quebra da relação entre agente etiológico e o hospedeiro, mediada pelo ambiente (tríade epidemiológica).

Por outro lado, no mesmo volume, a partir do contexto "órgãos dos sentidos", é discutida a relação entre condições ambientais e a saúde, especialmente aquelas ligadas ao trabalho infantil em carvoarias. Nesse sentido, as condições de vida e trabalho, assim como situações de vulnerabilidade estão contempladas na discussão acerca da saúde.

Os temas relacionados à saúde se concentram no volume para o segundo ano - na apresentação dos órgãos dos sentidos, reconhecimento das partes do corpo e hábitos de higiene - e especialmente no volume para o quinto ano, quando da apresentação dos órgãos e sistemas. Nos volumes para o $3^{\circ}$ e $4^{\circ}$ anos, são pouco tratados, restringindo-se a exemplos ou aspectos factuais.

Para o terceiro ano, a discussão central está relacionada ao ambiente, na qual a saúde aparece como exemplos nas discussões acerca da poluição, ambiente urbano (incluídas aqui orientações relacionadas à prevenção de acidentes com substâncias tóxicas ou inflamáveis) e saneamento. No volume para o quarto ano, no contexto "Seres Vivos", são descritas algumas doenças causadas por microrganismos (bactérias, fungos e protozoários), adotando o modelo de descrição do agente, sintomas, meios de transmissão e medidas de prevenção. Além disso, há uma extensa descrição da descoberta da penicilina e seu papel histórico, no intuito de ressaltar como as descobertas feitas pelos cientistas modificam o cotidiano, assim como certa "casualidade" do método científico, exemplificado pelo relato das descobertas de Fleming.

No volume para o quinto ano, há uma discussão sobre as doenças mais comuns do Brasil, na qual não são discutidas as relações existentes entre os aspectos sociais, econômicos e de condição de vida e a prevalência dessas doenças apresentadas, ficando marcada, nesse caso, certa naturalização ou aleatoriedade no aparecimento ou não das mesmas. Na discussão acerca da alimentação não são tratados os aspectos mais amplos da alimentação, tais como hábitos e costumes regionais ou os relacionados às questões econômicas e de acesso à alimentação de boa qualidade e em quantidade suficiente não são mencionados, aspecto esse que acaba por imprimir um forte caráter prescritivo no desenvolvimento desses conteúdos.

Grande parte desse volume é dedicada à discussão da relação entre tecnologia e saúde, com destaque para o trabalho da Fundação Oswaldo Cruz (FIOCRUZ). Nesse contexto, aparece a discussão acerca da importância da vacinação, com ênfase na vacinação gratuita e 
no cartão de vacinação como direitos de toda criança, a partir das seguintes afirmações: "todo brasileiro recém-nascido tem o direito de receber a Caderneta de Saúde” (vol. $5^{\circ}$ ano, p.26), ou "os postos de saúde oferecem, gratuitamente, as vacinas do calendário básico de vacinação durante o ano todo" (vol. $5^{\circ}$ ano, p.31), que explicitam a ideia do acesso à assistência à saúde como um direito de todos.

No tópico relativo à fecundação humana, no contexto da apresentação dos sistemas do corpo humano, há apenas a descrição biológica do processo: "para se formar um novo indivíduo, é preciso que as células sexuais masculinas se encontrem com as células sexuais femininas." (vol. $5^{\circ}$ ano, p. 132). Nas orientações para os professores há a recomendação de que "caso queira comentar com os alunos, em espécies de mamíferos, aves, répteis e peixes, a fecundação ocorre dentro do corpo da fêmea. Para isso, o macho e a fêmea precisam ter a relação sexual." (vol. $5^{\circ}$ ano, p.132). Dessa maneira, desconsidera-se, a partir desse "distanciamento técnico" onde o ser humano é comparado outras espécies de "aves, répteis e mamíferos", todas as questões (sociais, afetivas, comportamentais, culturais etc.) relacionadas à sexualidade humana, as medidas de prevenção e cuidados relativos às DST e a Aids, assim como relacionadas à gravidez indesejada na adolescência.

Pode-se dizer, portanto, que a coleção se caracteriza por certa naturalização da discussão acerca da saúde, na medida em que é enfatizada apenas sua dimensão biológica, em detrimento dos aspectos sociais que influenciam este processo. Exemplo dessa abordagem é o tratamento do tema da fecundação humana, que procura desvincular o processo de todas as questões que envolvem a sexualidade humana, numa tentativa novamente de naturalizar o processo (ou restringi-lo apenas a sua dimensão biológica), ou ainda, na discussão das doenças mais comuns no Brasil sem que se faça relação com os fatores que propiciam o aparecimento dessas doenças. Além disso, há claramente a visão de que o desenvolvimento de hábitos e atitudes relacionadas à higiene, desenvolvidos a partir do indivíduo, a fim de modificar a relação entre o agente, o ambiente e o hospedeiro, é o principal foco das unidades que tratam da saúde. Em função dessa tendência à naturalização, é possível dizer que há uma importante contradição entre o que é apresentado como perspectiva relacionada à saúde, que incorpora aspectos amplos relacionados ao processo saúde-doença, e o que é efetivamente desenvolvido no decorrer dos quatro anos. 


\section{Coleção 886}

A coleção se apresenta como estruturada a partir da proposta dos PCN, incorporando a saúde como "tema transversal", utilizando a perspectiva de eixos temáticos proposta por esses documentos, dentre estes o eixo "ser humano e saúde". O tema da saúde está presente tanto em unidades específicas, quanto em unidades nas quais não é o assunto principal, principalmente em sessões denominadas "dicas de saúde" que, segundo as , orientações para os professores, "apresentam textos curtos e conclusivos que visam transmitir orientações relacionadas à saúde corporal e à higiene", cabendo ao professor "incentivar a prática e o hábito do que é sugerido nessas dicas, tornando a vida dos alunos mais saudável." (vol. $2^{\circ}$ ano, p.22, orientações para os professores).

Predominantemente, ao apresentar os assuntos relacionados à saúde existe a preocupação com a descrição de doenças específicas. Os conteúdos são relacionados à descrição do agente etiológico, dos sintomas, das formas de transmissão e das atitudes de prevenção e cuidados específicos, para doenças específicas. Claramente, a preocupação está relacionada, desde o primeiro momento, ao conhecimento sobre a doença e relativo às atitudes de prevenção. Ou seja, o mote saúde é utilizado para tratar de assuntos relacionados à doença.

Como exemplo, pode-se apontar uma unidade intitulada “Água e Saúde” (vol. $3^{\circ}$ ano, unidade 4) que trata basicamente da descrição de doenças veiculadas pela água (leptospirose, esquistossomose, dengue e cólera). Essas doenças são apresentadas a partir do modelo acima descrito (descrição do agente, meios de transmissão, sintomas e atitudes de prevenção) e a ênfase está nos aspectos biológicos e naturais da relação entre o agente e o hospedeiro, onde a relação entre água e saúde (título da unidade) se dá pela descrição de doenças veiculadas pela água. Em outras palavras, ao se propor a falar de saúde, fala-se da doença.

Outro exemplo claro está na unidade "prevenção de doenças" (vol. $2^{\circ}$ ano), que trata das principais doenças da infância e tem como objetivos centrais "identificar as causas e os sintomas de algumas doenças" e "conhecer como as verminoses são causadas e os cuidados para a sua prevenção.” (vol. $2^{\circ}$ ano, p.35, orientações para os professores). Nessa mesma unidade há, na sessão "avanços da ciência", uma longa descrição de uma vacina contra o vibrião colérico e diarreias causadas por Escherichia coli, produzida por um laboratório privado (e não disponível no serviço público de saúde) que é descontextualizada e sem relação com o restante da unidade, cabendo perguntar o propósito pedagógico dessa inserção. 
Nesse sentido, a utilização desse modelo descritivo da doença na apresentação dos conteúdos relacionados à saúde aponta para uma predominância da concepção desta relacionada à ausência da doença, onde os determinantes são basicamente de natureza biológica e as orientações têm caráter individual, voltadas à prevenção de doenças ou agravos específicos.

Nas unidades referentes à alimentação, os objetivos estão ligados à mudança e consolidação de hábitos alimentares considerados saudáveis. Há concomitantemente uma grande preocupação com os aspectos ligados à higiene na manipulação e armazenamento dos alimentos e o risco de doenças infectocontagiosas.

Nesse contexto, na sessão "Ler para refletir" do volume para o $4^{\circ}$ ano (p.25) é proposta uma discussão sobre desnutrição, relacionando-a a má distribuição dos alimentos e não à falta deles. Há, portanto, a incorporação de aspectos socioeconômicos ligados à alimentação. Porém, na mesma sessão, a desnutrição não é vista como um problema em si, pois ao afirmar que "a desnutrição ocorre pela falta de nutrientes no corpo e pode causar doenças" (p.25) aponta novamente para uma concepção de saúde como ausência de doenças, ligada à presença ou não de sintomas ou de agentes infecciosos, sendo a desnutrição a condição favorável a essa presença.

Os determinantes sociais ligados às condições de vida e sua relação com a saúde aparecem muito pouco na coleção. Estão presentes na apresentação dos conteúdos relativos ao aparelho reprodutor humano (vol. $5^{\circ}$ ano), quando da discussão sobre o papel da informação e o contágio pelo HIV e na discussão acerca da gravidez indesejada na adolescência, onde são tratados os custos financeiros e as "perdas sociais" de caráter pessoal que uma gravidez nessa idade pode acarretar tanto para as meninas, quanto para os meninos.

Esses determinantes aparecem também na discussão acerca do tratamento do lixo e do saneamento básico, no contexto da discussão sobre a preservação do ambiente, especificamente nas unidades denominadas como "Ambiente" ( $3^{\circ}$ e $4^{\circ}$ anos). Nessas unidades fica clara a discussão do saneamento como um direito, que deve ser garantido pelos órgãos públicos. Nesse sentido, pode-se inferir que, mesmo não explicita e diretamente, o direito à saúde está aí colocado. Como será aprofundado adiante, é pertinente ressaltar que essa perspectiva é comum a muitas coleções, onde o direito ao saneamento está mais relacionado à preservação do ambiente do que propriamente à prevenção de doenças ou como estratégia de promoção da saúde. Ou seja, o saneamento é predominantemente visto como importante para a preservação ambiental e não como uma estratégia que visa garantir melhores condições de 
saúde para a população. A saúde, nesse caso, é uma decorrência do saneamento e não seu objetivo.

Chama à atenção a última unidade do volume do $5^{\circ}$ ano (portanto, a última da coleção), intitulada "Nosso corpo: regulação, reprodução e manutenção da saúde", que trata das questões relacionadas à saúde de modo bastante distinto. A unidade é dividida em três blocos, sendo que os dois primeiros (regulação e reprodução) seguem o padrão da coleção, onde estão apresentadas as principais estruturas do sistema nervoso (incluindo órgãos dos sentidos), sistema endócrino e sistema reprodutor, apresentando algumas doenças relacionadas a eles, além de dicas sobre cuidados e medidas de prevenção. Adota-se, portanto uma visão de saúde muito mais voltada aos aspectos biológicos e de caráter marcadamente preventivista, bastante coerente com o restante da coleção.

No entanto, no seu terceiro e último bloco ("viver de modo saudável"), que é o subitem final dessa unidade e, portanto, último tópico relacionado à saúde da coleção, há uma total mudança de perspectiva em relação à visão de saúde. É possível dizer que em função dessa localização na coleção, esse item assume um caráter de síntese no que diz respeito à saúde. No entanto, apresenta uma visão bastante diferente daquela que vem sendo trabalhada ao longo de toda a coleção.

A sessão inicia-se da seguinte forma:

Para ser saudável, não basta que todos os sistemas orgânicos atuem em conjunto, garantindo o bom funcionamento do corpo. Nossas emoções e nossos sentimentos também interferem na saúde do organismo. Ter bom relacionamento social, lazer e dormir bem também são aspectos importantes para a saúde. Portanto, ter saúde não significa só a ausência de doenças. (vol. $5^{\circ}$ ano, p.139),

Portanto, a definição de saúde da OMS, passa a ser o pressuposto relacionado à saúde nessa unidade.

Além disso, as orientações são de caráter coletivo e estão voltadas ao bem-estar geral, não relacionadas a alguma doença ou agravo específico. Também são apresentados comportamentos e valores para a construção de "ambientes saudáveis", tanto dentro quanto fora da escola, o que relaciona a saúde com aspectos ainda não explorados $\mathrm{n}$ restante da coleção (relações sociais, valores, criação de ambientes favoráveis etc.).

No mesmo tópico, a sessão "dicas de saúde" é relacionada à prática de exercícios e brincar como fatores de bem-estar geral e coletivo. Novamente, a concepção aqui é bastante 
diferente das demais "dicas de saúde" da coleção que estavam relacionadas a atitudes de prevenção relacionadas a agravos específicos. No entanto, e a despeito das diferenças apontadas, o foco continua na mudança de hábitos e estilos de vida, apontando para uma perspectiva de promoção da saúde de caráter individualizado.

Sinteticamente, é possível dizer que a coleção adota um modelo para a apresentação dos conteúdos que privilegia o conhecimento sobre a doença, a apresentação de atitudes de prevenção específica de caráter individual, e que trata a saúde predominantemente a partir de seus aspectos biológicos. Os determinantes de outra natureza são pouco abordados durante toda a coleção.

Nesse sentido, é emblemático ressaltar a diferença de abordagem entre o último trecho analisado e o restante da coleção, assim como sua localização na coleção que sugere ter o papel de síntese dos tópicos relacionados à saúde. Parece-nos que há nessa unidade um esforço de aproximação da discussão da saúde proposta pela coleção com a definição da OMS, ou mesmo dos PCN para o ensino dos temas relacionados à saúde, que, em função das importantes diferenças existentes entre essa abordagem e o restante da coleção, se mostra de certa forma contraditório e artificializado.

\section{Coleção 907}

A coleção se estrutura a partir de um grande eixo denominado "Ambiente", que se subdivide em três. Um deles, "saúde individual e coletiva", tem por objetivo "compreender a relação entre os cuidados individuais com a saúde e a manutenção das boas condições da saúde da população" (vol. $2^{\circ}$ ano, p.05, orientações para os professores). Adicionalmente, em sua apresentação, o tema transversal "saúde" é apontado como estruturante em diversas unidades ou capítulos dos quatro volumes da coleção.

Apesar dessa preocupação com a dimensão coletiva da saúde, as orientações apresentadas no decorrer das unidades são marcadamente de caráter individual e têm como principal objetivo a aquisição ou mudança de hábitos e a orientação acerca de atitudes de prevenção de doenças ou agravos.

Em toda a coleção procura-se relacionar as questões de saúde com as condições do ambiente, especialmente relacionadas à poluição e saneamento. No entanto, ao fazer essa relação, não aparecem os aspectos socioeconômicos e de acesso a esses serviços como determinantes da situação de saúde. Em uma unidade que desenvolve esse tema há, nas 
orientações para os professores, um extenso conjunto de informações sobre doenças que são "transmitidas pela água contaminada", apontando a malária e, especificamente, a dengue, que utiliza o modelo de descrição da doença, agentes e vetores, sintomas e medidas de prevenção. (vol. $4^{\circ}$ ano, pp.30-32, orientações para os professores). Há aqui um importante equívoco, na medida em que os exemplos utilizados são de doenças transmitidas por vetores que necessitam da água (geralmente limpa e não contaminada) para sua reprodução e não são consideradas de veiculação hídrica ou "provocadas pela contaminação da água".

A apresentação dos conteúdos relacionados aos órgãos dos sentidos tem como um de seus objetivos o reconhecimento por parte dos alunos e do professor de possíveis deficiências de audição e visão, algo comum a muitas coleções e bastante pertinente, na medida em que tais conteúdos são desenvolvidos no início da coleção, auxiliando o professor na detecção de possíveis deficiências por parte dos alunos que poderão comprometer sua vida escolar. É importante ressaltar que essa preocupação com o autoconhecimento e o desenvolvimento de atitudes de autocuidado está presente em toda a coleção, relacionada a diversos contextos (higiene, mudanças ocorridas nas diversas fases da vida, hábitos de proteção etc.).

Quando da apresentação de conteúdos relacionados às doenças infectocontagiosas é utilizado o modelo de descrição da doença, seu agente etiológico, meios de transmissão e medidas de prevenção, não ficando claro outros fatores (sociais, econômicos, culturais) como determinantes do processo saúde-doença. A exceção aparece na discussão sobre Mal de Chagas, apresentada no bojo dos conteúdos relacionados à organização e funcionamento do corpo humano (sistema circulatório), onde é explicitada a relação entre as condições precárias de moradia e a presença da doença. Vale dizer que a associação entre as condições de moradia e situações de saúde quando da apresentação dos conteúdos relacionados ao Mal de Chagas é clássica no ensino de ciências, na medida em que, para essa doença, essa associação é bastante evidente e, de certa forma, didática.

Os conteúdos relacionados às Doenças Sexualmente Transmissível, assim como à gravidez na adolescência aparecem, no quinto ano, com forte preocupação com a aquisição de atitudes de prevenção e autocuidado. Nesse contexto, é apresentado o uso do preservativo masculino como principal medida de prevenção das DST. Os aspectos sociais e culturais são abordados nessa discussão em função do "não preparo" dos adolescentes (tanto as meninas quanto os meninos) para as responsabilidades relacionadas à maternidade/paternidade.

Nas unidades referentes à alimentação e nutrição, a saúde é apresentada como equilíbrio e seus objetivos estão ligados à mudança e consolidação de hábitos alimentares 
considerados saudáveis. Há a preocupação com a classificação dos alimentos, a partir da ideia da alimentação variada como aspecto de saúde, assim como com aspectos de higiene na manipulação e armazenamento dos alimentos e o risco de doenças infectocontagiosas. Uma das unidades relacionadas ao tema parte da premissa de que "as crianças precisam comer de três a quatro porções de fruta por dia" (vol. $3^{\circ}$ ano, p.16), e tem como foco a discussão acerca da importância e o hábito de comer frutas e sua relação com a manutenção da saúde. Vale perguntar até que ponto essa afirmação, entendida como prescrição de boa alimentação, é pertinente e possível à realidade dos alunos, correndo o risco de culpabilização dos indivíduos pelo não alcance dessa frequência diária desejável.

É possível dizer que, apesar de explicitar em sua apresentação a preocupação com a dimensão coletiva da saúde, a coleção apresenta na maioria das discussões a preocupação com o desenvolvimento de atitudes e práticas de prevenção tendo o indivíduo como foco e a ideia de autocuidado como pano de fundo. Coerentemente, os aspectos sociais, econômicos e culturais aparecem de maneira bastante difusa e são pouco enfatizados, mesmo quando relacionados às condições ambientais. Nesse sentido, pode-se inferir que se corre o risco de naturalização ou aleatoriedade das condições de saúde dos indivíduos ou da população, ou que esta situação está baseada apenas em um conjunto de atitudes ou comportamentos de caráter preventivo, que devem ser seguidos pelos alunos a fim de manter sua saúde.

\section{Coleção 924}

Assim como expresso na sua apresentação para os professores, um dos objetivos da coleção é o de "valorizar a saúde individual e coletiva" (vol. $2^{\circ}$ ano, p.06, orientações para os professores). Em toda a coleção existem sessões com marcadores denominados "saúde" que indicam, segundo as , orientações para os professores, que esse "tema transversal" está sendo trabalhado, independentemente do objeto específico da unidade.

Para o segundo ano, a ênfase está no reconhecimento por parte dos alunos dos órgãos dos sentidos e, principalmente, na discussão sobre prevenção de doenças, a partir da aquisição de hábitos de higiene pessoal e relacionados à alimentação. Essa relação entre saúde e ausência de doenças é bastante clara na unidade "tudo limpo" onde são enfatizados tais hábitos como estratégias para ter uma "vida saudável".

No volume para o $3^{\circ}$ ano, no contexto "seres humanos", há uma sessão intitulada "o corpo saudável" onde se explicita uma definição de saúde como desempenho: "ter saúde é ter 
o corpo e a mente funcionando bem." (vol. $3^{\circ}$ ano, p.126). Além disso, relaciona-se a saúde com uma série de comportamentos: "quando estamos saudáveis, temos vontade de brincar, de aprender, de comer e de conviver com as outras pessoas" (vol. $3^{\circ}$ ano, p.127). Esse desempenho, portanto, essa saúde está diretamente associada aos hábitos de higiene, alimentação, atividades físicas e aspectos de relacionamento interpessoal (ter amigos, estudar, ler, ouvir música, brincar e dormir bem etc.). No texto de apoio aos professores especifico dessa unidade, há a referência ao papel do professor como propiciador da aquisição desses hábitos de higiene e comportamentos saudáveis por parte dos alunos.

É importante ressaltar que todas as recomendações são de ordem individual, ligadas às escolhas pessoais. Não são tratadas na dimensão coletiva e tampouco relacionadas aos aspectos sociais, econômicos ou culturais dos alunos. Nesse sentido, têm um forte caráter prescritivo e de responsabilização dos indivíduos pela sua saúde, baseadas na perspectiva do estilo de vida. Vale apontar que nessas mesmas orientações para os professores é apontado que "os alunos devem entender a saúde como um estado de bem-estar físico, mental e social" (vol. $3^{\circ}$ ano, p.97, orientações para os professores), adotando a perspectiva do bem-estar, o que é profundamente contraditório com o desenvolvimento do conteúdo da unidade, na medida em que não são abordados os aspectos coletivos inerentes a essa última definição.

Ao discutir a interação entre os animais ( $4^{\circ}$ ano), são apresentadas de maneira clássica algumas das parasitoses mais comuns (descrição da doença, agente, meios de transmissão, atitudes de prevenção). A ênfase se dá na prescrição de atitudes de prevenção, sem que haja menção às condições de vida, saneamento e moradia, por exemplo, e a presença ou não dessas verminoses. Existe a referência da importância em discutir aspectos não somente relacionados aos hábitos de higiene pessoal apenas nas, orientações para os professores, onde são abordados aspectos mais amplos relacionados à dimensão coletiva da saúde. Nesse sentido, pode-se perguntar novamente sobre o porquê da ausência dessa discussão no material para os alunos. Em outras palavras: por que não discutir os aspectos mais amplos relacionados à saúde (no caso, as parasitoses) diretamente no material dos alunos, que se restringe à descrição dos parasitas e das doenças recorrentes?

$\mathrm{Na}$ apresentação dos sistemas do corpo humano é enfatizada a descrição dos principais órgãos e suas funções. $\mathrm{O}$ tema da alimentação é tratado na discussão geral acerca do sistema digestório, onde a questão da obesidade é abordada de maneira a responsabilizar o indivíduo diretamente por sua saúde, retomando mais uma vez a perspectiva do estilo de vida e tratando a saúde apenas como uma questão relacionada às escolhas pessoais. Além disso, há uma 
associação direta bastante questionável entre a ausência de obesidade como sinal de saúde e a relação desta com a felicidade:

cuide bem do seu corpo. Cuidar da saúde não é só dever dos médicos, enfermeiros e dentistas. É, principalmente, dever de cada um. Para não sofrer as consequências de obesidade e prevenir muitas doenças, veja abaixo algumas dicas para ter uma vida mais saudável e feliz. (vol. $5^{\circ}$ ano, p.99).

Novamente, não há referências aos fatores socioeconômicos e culturais relacionados à alimentação, fato que imprime um caráter prescritivo e descontextualizado na discussão.

A apresentação dos conteúdos relativos ao aparelho respiratório é utilizada para apresentar questões acerca do tabagismo e as consequências para a saúde, incorporando a ideia de fumante passivo. O sistema musculoesquelético é mote para a discussão da relação entre atividade física e saúde e relacionada aos problemas posturais. Todas essas discussões estão novamente baseadas na ideia de estilo de vida e escolhas pessoais, na medida em que a ênfase as dá na aquisição de "atitudes saudáveis", de caráter individual.

No que tange aos conteúdos relacionados ao aparelho reprodutor humano, a discussão acerca das questões relacionadas à sexualidade (orientação sexual, métodos contraceptivos, DST/Aids etc.) está apontada apenas do material para os professores, com uma orientação enfática sobre a importância do desenvolvimento desses temas em sala de aula, sem que haja relação com o material destinado aos alunos, que se restringe a descrição dos órgãos dos aparelhos masculino e feminino. No tocante à fecundação, há a discussão dos aspectos sociais (perdas sociais e responsabilidades) relacionados à gravidez na adolescência tanto para meninas quanto para meninos, sem que haja referência aos cuidados ou métodos contraceptivos, que aparece apenas no material destinado aos professores. A observação anteriormente formulada do contexto das parasitoses é válida também nesse contexto.

A apresentação do sistema nervoso propicia a discussão sobre alcoolismo, ressaltando as perdas sociais (acidentes automobilísticos e dificuldades de relacionamento) e danos físicos decorrentes do uso abusivo de álcool. Além desse tópico, são retomados os conteúdos relacionados aos órgãos dos sentidos de maneira mais aprofundada.

Sintetizando, mesmo apontando na sua apresentação a preocupação em desenvolver os temas da saúde a partir de uma abordagem que inclua sua dimensão coletiva, a coleção enfatiza a aquisição de hábitos como principal estratégia voltada à saúde, tendo como premissa a ideia de estilo de vida. Sejam relacionados à higiene pessoal, à alimentação, à prática de atividades físicas e hábitos de descanso, ou mesmo aos aspectos ligados às relações 
interpessoais, a saúde está claramente baseada em um conjunto de escolhas de caráter individual. Os aspectos sociais, econômicos e culturais da saúde, assim como sua dimensão coletiva, aparecem de maneira bastante diluída durante toda a coleção e, quando aparecem, não são o foco central da discussão. Além disso, a relação entre saúde e felicidade, associadas à obesidade (ou à ausência dela), assim como apresentada em uma unidade do quinto ano, reforça a perspectiva do estilo de vida, e toda a crítica que se faz a ela, como se o fato de ser obeso (ou feliz) fosse apenas uma questão de escolha de caráter pessoal.

Com essa análise buscamos apontar as importantes diferenças existentes entre as coleções no que diz respeito à abordagem dos temas relacionados à saúde, o que aponta para a necessidade de compreender esse conjunto de livros didáticos não de maneira homogênea ou monolítica, mas sim permeado por visões acerca da saúde e de seus fatores determinantes e, consequentemente, objetivos pedagógicos relacionados ao tema bastante distintos.

Essas diferenças aparecem de forma mais marcante quando relacionadas ao papel atribuído aos fatores naturais ou historicamente constituídos como determinantes do processo saúde-doença. Enquanto algumas coleções enfatizam e priorizam a discussão dos aspectos naturais, entendidos aqui como os que dizem respeito à biologia, fisiologia dos indivíduos e relacionados à presença de agentes etiológicos ou suscetibilidades individuais - o que os PCN denominam como "biologismo" -, outras procuram abordar a saúde a partir de discussões que incorporem aspectos de outra natureza, tais como as condições socioeconômicas, a cultura e hábitos locais, as condições de moradia etc.

Relacionada a esse aspecto, uma diferença importante entre as coleções diz respeito à incorporação ou não dimensão coletiva da saúde no desenvolvimento de seus conteúdos. A despeito dessas diferenças, pode-se perceber uma significativa tendência em privilegiar a dimensão individual em detrimento da coletiva, que, como será discutido ao final da análise geral é profundamente coerente com os objetivos das unidades (ligados às orientações voltadas à prevenção específica), assim como à concepção de saúde mais presente nesse conjunto de livros. Nesse sentido, as coleções que procuram abordar o tema tendo como pressuposto o direito à saúde e consequentemente sua dimensão coletiva, que procuramos apontar nas descrições acima, podem ser consideradas como exceções nesse conjunto.

Como dito anteriormente, o limite dessa análise é não possibilitar a visão do conjunto de livros como um todo. Assim, procuramos destacar as marcas distintivas de cada coleção a fim de demarcar e destacar as importantes diferenças existentes entre as coleções. 
Por pouto lado, a análise apresentada a seguir buscou compreender como a saúde é abordada no conjunto dos livros e não mais em cada coleção separadamente. Entendemos que o cotejamento entre as análises individuais das coleções e o conjunto dos livros possibilita uma compreensão de como a saúde é abordada nos livros didáticos de maneira a contemplar e complementar os limites dados por esta ou aquela proposta analítica.

\subsection{Análise Geral}

Esse plano de análise buscou apreender como a saúde humana é abordada no conjunto das coleções analisadas, no intuito de traçar uma visão geral acerca da temática da saúde nos anos iniciais do Ensino Fundamental. Foram analisados os temas e conteúdos, assim como o momento em que são desenvolvidos nesse ciclo de escolaridade; as concepções de saúde que estão expressas das unidades; os determinantes do processo saúde-doença mais enfatizados e os objetivos pedagógicos relacionados à saúde propostos pelos livros.

Diferentemente da análise por coleção, que teve por objetivo apresentar e discutir as marcas distintivas e os aspectos que chamam à atenção em cada uma das coleções analisadas, o esforço aqui foi o de sintetizar, a partir das categorias propostas, as características gerais para este conjunto dos livros. Para tanto, cada uma das unidades selecionadas foi analisada a partir de uma matriz analítica (anexo 2) e os resultados aqui apresentados e discutidos foram obtidos em função da frequência e da porcentagem com que aparecessem nesse conjunto.

O limite dessa proposta de análise é o fato de não ser possível cotejar a importância ou o "peso" que cada uma das unidades tem no volume analisado ou na coleção como um todo, na medida em que estas foram analisadas como unidades independentes. Nesse sentido, muito mais do que caracterizar os livros, buscou-se estabelecer uma visão geral dos 44 volumes analisados. Isto não quer dizer que esse conjunto deva ser entendido como uniforme ou homogêneo e que as importantes diferenças existentes entre as coleções, assim como apresentadas anteriormente, não devam ser levadas em conta.

\subsubsection{As unidades de análise e os anos de escolaridade}

No conjunto dos 44 volumes analisados foram selecionadas, a partir dos critérios de inclusão já apresentados, 289 unidades de análise que dizem respeito às unidades propriamente ditas, capítulos ou trechos dos livros didáticos que tinham como objetivo apresentar conteúdos ou discussões acerca de temas relacionados à saúde humana. Nesse 
sentido, os trechos selecionados não se restringiram àqueles onde a saúde é o foco principal. Mesmo que pertencentes a unidades nas quais o objeto não diz respeito à saúde diretamente, alguns trechos foram selecionados em função de orientações ou "dicas" de saúde. Como exemplos, podem ser citados os trechos relacionados às orientações sobre os cuidados relativos aos acidentes com eletricidade, quando da discussão acerca de energia; as unidades relativas à classificação dos animais e a incorporação dos cuidados e atitudes de prevenção relacionadas aos parasitas internos e externos ou a animais peçonhentos; ou ainda, a discussão sobre os danos à saúde causados pela poluição atmosférica ou relacionados ao saneamento básico no contexto Ambiente, dentre outros.

É importante ressaltar que, assim como na análise por coleção, foram analisados tanto o material destinado aos alunos quanto aquele que compõe as orientações para os professores (apresentação da coleção como um todo, orientações específicas para cada uma das unidades e textos de apoio).

É possível afirmar que o tema da saúde está bastante presente nessa fase de escolarização ocupando grande parte do livro didático e, em função do papel por desempenhado por esse material no cotidiano escolar, é possível dizer que o tema da saúde ocupa boa parte do currículo de Ciências para os anos iniciais do Ensino Fundamental.

Quanto à estrutura geral das coleções, um primeiro aspecto a ser destacado é que muitas coleções analisadas adotam estrutura de eixos temáticos propostas pelos Parâmetros Curriculares Nacionais (Ser Humano e Saúde, Ambiente, Recursos Tecnológicos e Terra e Universo) e se referem de maneira explícita ao trabalho com temas transversais em muitas das unidades onde são desenvolvidos conteúdos relacionados à saúde. Esse aspecto denota a forte influência que os Parâmetros, mesmo não tendo caráter obrigatório, ainda exercem na elaboração dos livros didáticos, pelo menos quando da apresentação de suas propostas e projetos pedagógicos.

A despeito das diferenças apresentadas entre as coleções, percebe-se que a discussão sobre saúde está presente de maneira bastante homogênea nos três primeiros anos, apresentando certa concentração no quinto ano. (tabela 1).

\begin{tabular}{|c|c|c|c|c|c|}
\hline Unidades analisadas & \multicolumn{4}{|c|}{ Anos } & \multirow{2}{*}{$\begin{array}{l}\text { Total de unidades } \\
\text { da coleção }\end{array}$} \\
\hline Código da coleção & $2^{\circ}$ & $3^{\circ}$ & $4^{\circ}$ & $5^{\circ}$ & \\
\hline 611 & 6 & 11 & 4 & 17 & 38 \\
\hline 632 & 6 & 7 & 3 & 11 & 27 \\
\hline 651 & 9 & 3 & 6 & 7 & 25 \\
\hline
\end{tabular}




\begin{tabular}{c|c|c|c|c|c}
674 & 4 & 5 & 7 & 4 & 20 \\
\hline 663 & 4 & 3 & 7 & 2 & 16 \\
\hline 679 & 7 & 3 & 4 & 14 & 28 \\
\hline 675 & 8 & 4 & 1 & 13 & 26 \\
\hline 793 & 6 & 3 & 5 & 15 & 29 \\
\hline 886 & 5 & 7 & 5 & 11 & 28 \\
\hline 907 & 5 & 5 & 7 & 6 & 23 \\
\hline 924 & 5 & 11 & 9 & 4 & 29 \\
\hline Total por ano & $\mathbf{6 5}$ & $\mathbf{6 2}$ & $\mathbf{5 8}$ & $\mathbf{1 0 4}$ & $\mathbf{2 8 9}$ \\
\hline
\end{tabular}

Tabela 1: número de unidades analisadas por coleção e ano. Geral das coleções

O gráfico a seguir mostra a distribuição percentual das unidades selecionadas ao longo desses quatro anos de escolaridade (gráfico 1). Ou seja, do total de unidades analisadas pouco mais de um terço (36\%) dizem respeito á trechos selecionados nos volumes para o quinto ano. Tal concentração pode ser explicada em função do desenvolvimento dos conteúdos relacionados à organização e funcionamento do corpo humano, onde são apresentadas a anatomia e fisiologia dos principais sistemas que por tradição é enfatizado neste ano.

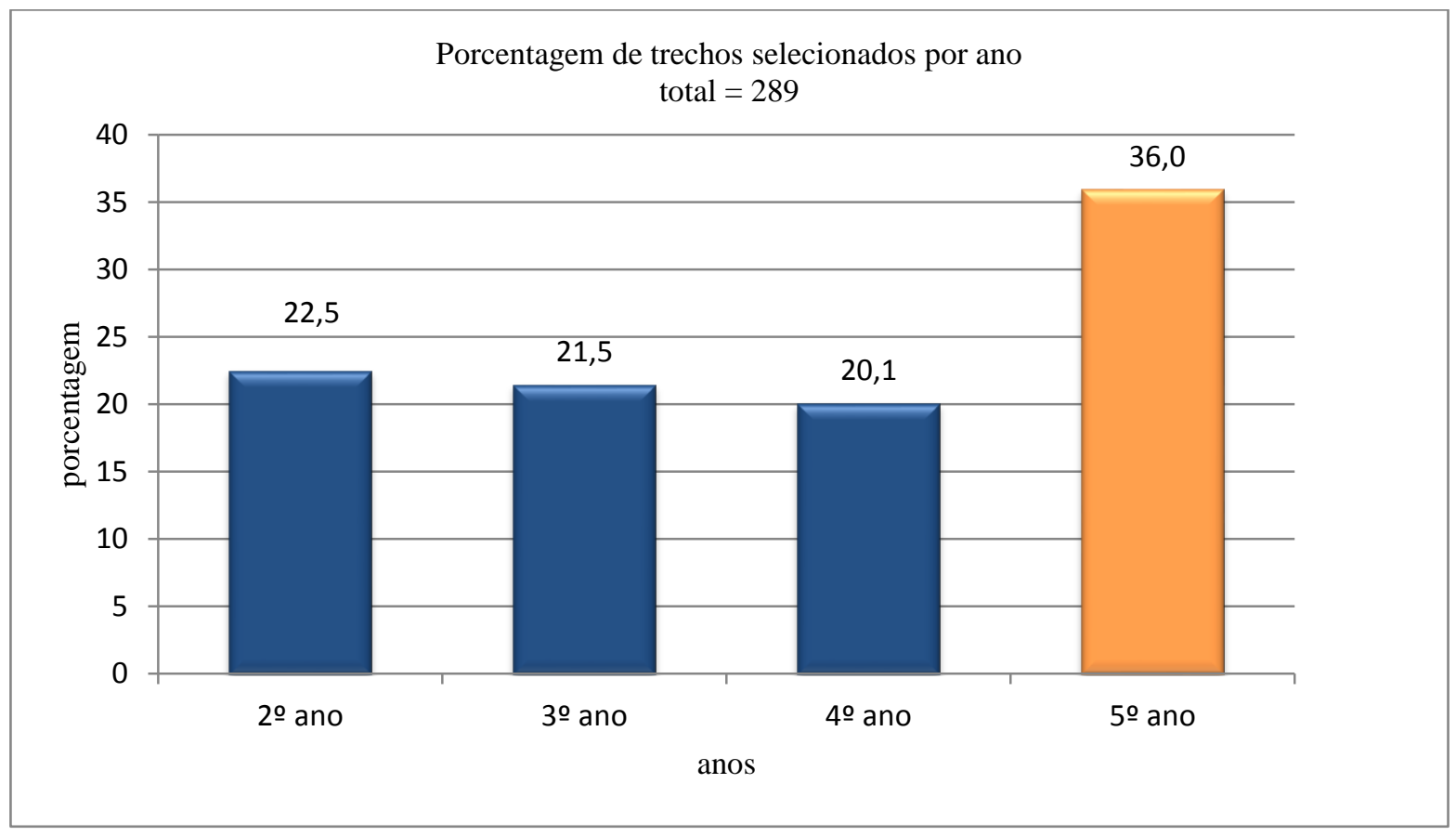

Gráfico 1: distribuição porcentual dos trechos selecionados por anos de escolaridade.

Partindo do pressuposto de que o livro didático desempenha importante papel na definição desses conteúdos e na abordagem proposta para o seu desenvolvimento, os temas desenvolvidos, as concepções de saúde, a natureza dos determinantes apontados como principais, assim como a forma de apresentação e a ênfase dada a certos conteúdos em 
detrimento de outros, acabam por conformar determinado entendimento acerca da saúde e das possibilidades de modificação das situações de saúde vividas tanto pelos alunos quanto pelos professores.

Entendido como percurso educacional (FORQUIN, 1993) e como instrumento de construção da identidade dos alunos (SILVA, 2003), o currículo escolar está baseado fortemente, não se restringindo a eles, nos temas e assuntos discutidos em sala de aula, assim como nas abordagens que os professores utilizam para desenvolvê-los. É possível dizer, portanto, que o modo como são desenvolvidos os temas relacionados à saúde nos LD conformam ou, no mínimo, influenciam fortemente o currículo de saúde nos anos iniciais do Ensino Fundamental. A análise apresentada a seguir, muito mais do que qualificar ou avaliar os livros didáticos da amostra, buscou compreender quais são essas marcar curriculares, assim como apontar suas implicações para o ensino da saúde e para a formação geral dos alunos.

\subsubsection{Os Temas: o comum e o episódico}

A partir da análise das 289 unidades foi possível mapear, após serem agrupados por semelhança, 34 temas distintos relacionados à saúde. Esse mapeamento mostrou que alguns temas aparecem de forma frequente e em todas as coleções, tais como os relacionados à alimentação e nutrição, à saúde bucal, à higiene pessoal, às doenças de veiculação hídrica e a importância do consumo de água tratada, à descrição e funcionamento dos órgãos e estruturas e órgãos dos sentidos. Em contrapartida, as discussões acerca das condições de vida e moradia e sua relação com a saúde, as relacionadas à imagem corporal e sua relação com comportamentos prejudiciais à saúde (uso de esteroides ou distúrbios alimentares), ou mesmo as que tenham por objetivo definir o que é saúde aparecem pouco frequentemente. A figura abaixo mostra o número de coleções que abordam cada um dos 34 temas mapeados. (gráfico 2). 


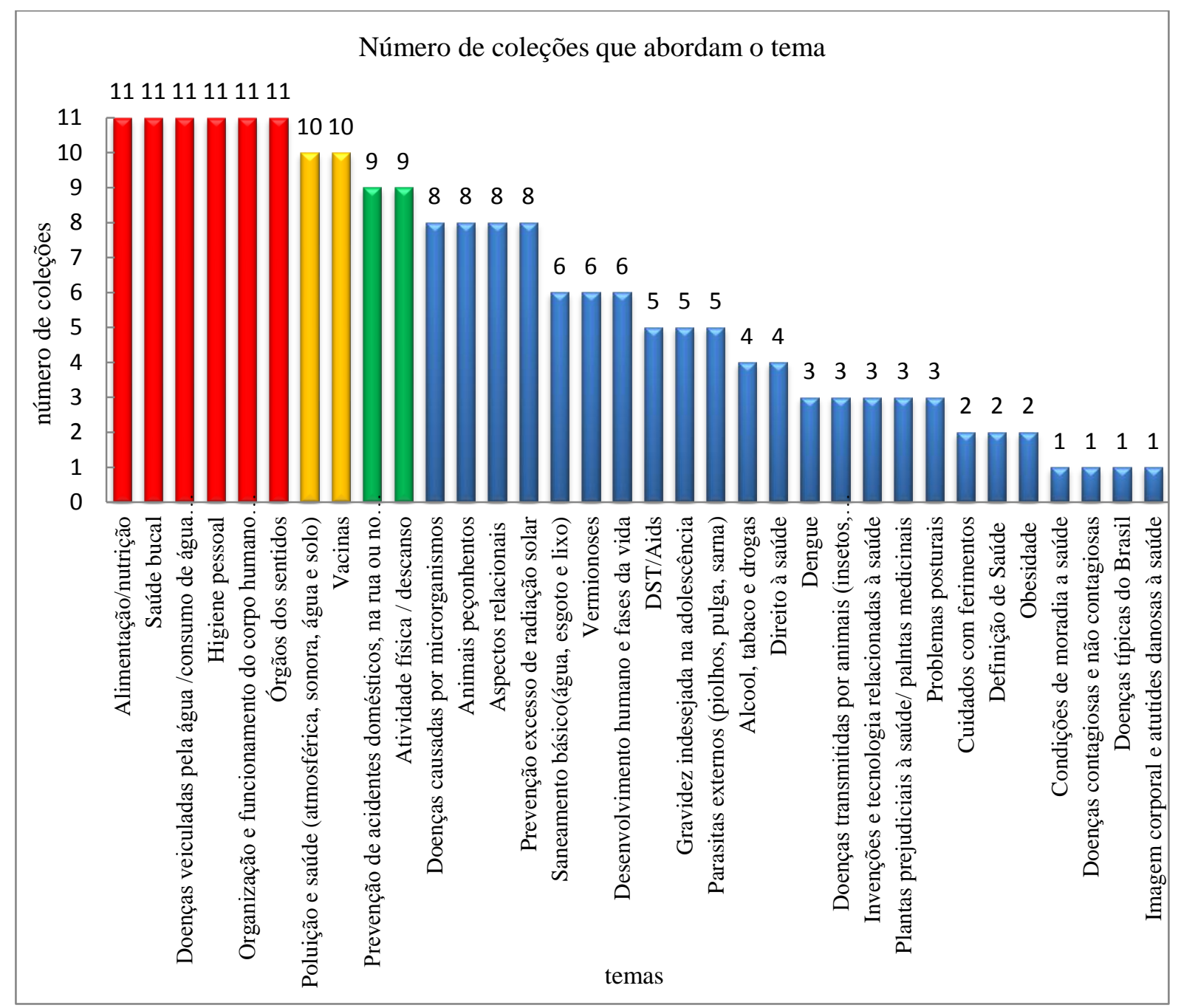

Gráfico 2: número de coleções que abordam os temas. Geral dos anos.

Além disso, foi possível mapear os temas mais frequentes por ano.

Para o segundo ano, foram mapeados 21 temas, sendo os mais frequentes relacionados à apresentação dos órgãos dos sentidos e aos hábitos de higiene pessoal, que aparecem em todas as coleções e podem ser considerados, portanto, como marcas distintivas dos conteúdos relacionados à saúde para esse ano (figura 3). 


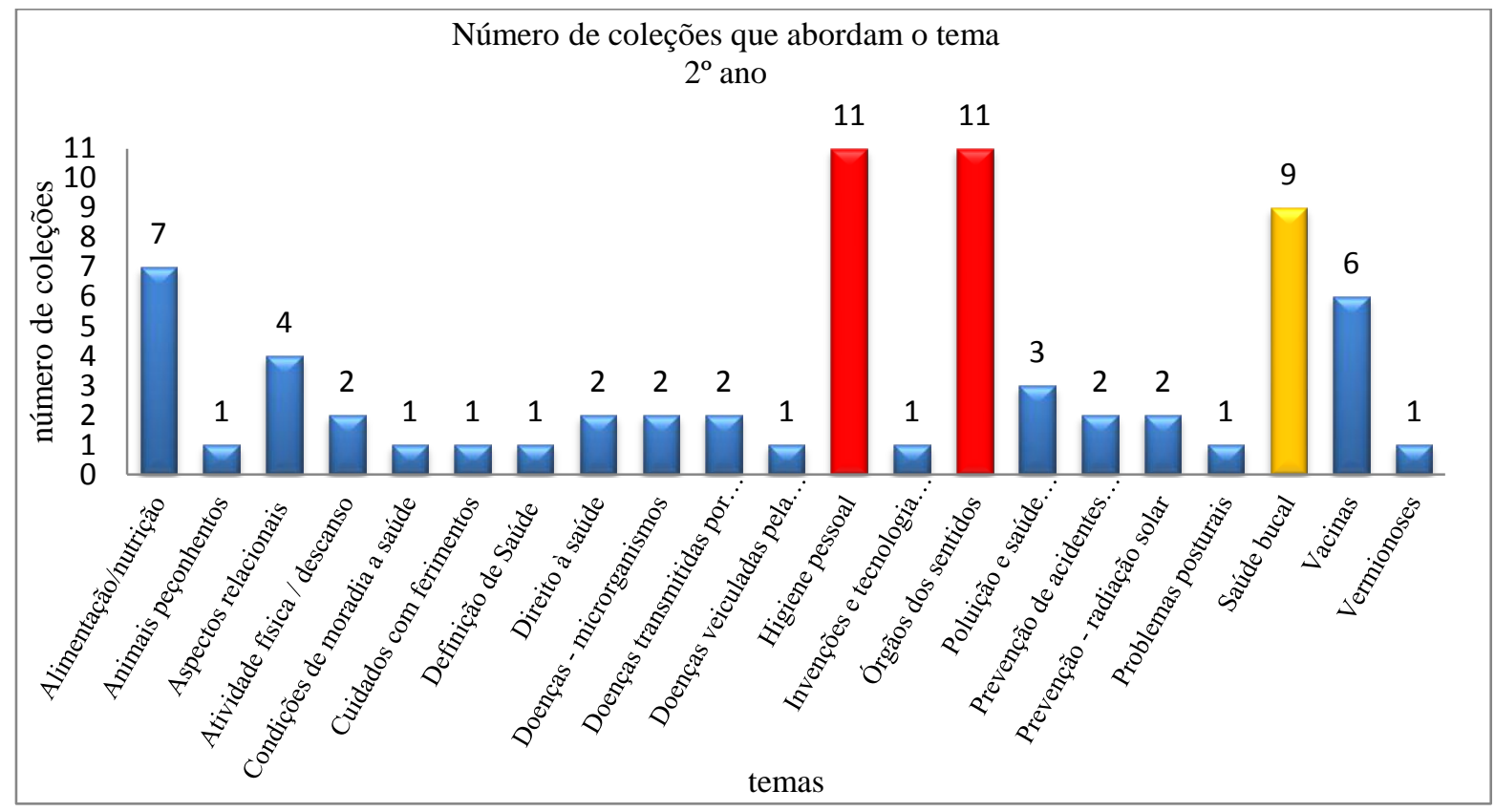

Gráfico 3: número de coleções que abordam o tema. $2^{\circ}$ ano

Quanto aos órgãos dos sentidos, o objetivo está relacionado à apresentação das estruturas e suas funções, aos cuidados com a higiene, à prevenção de acidentes e cuidados específicos, assim como à utilização dos sentidos para a detecção de situações de perigo. Adicionalmente, fica evidente, tanto no material destinado aos alunos, quanto nas orientações para os professores a preocupação com a detecção de possíveis deficiências, principalmente relacionadas à visão e audição, como expressa no exemplo a seguir: "se você não enxerga bem, converse com o seu professor. Ele poderá orientar seus pais ou responsáveis a encaminhá-lo a um médico especialista em olhos” (col. 886, vol. $2^{\circ}$ ano, p. 14).

No que tange ao tema da higiene pessoal, a discussão recai sobre a importância do banho e da higiene pessoal em geral, incluída aí a higiene bucal. Essa importância é estabelecida em função do estabelecimento da relação entre a falta de higiene e a presença de microrganismos transmissores de doenças, como também relacionada ao bem-estar: "A higiene, isto é, a limpeza do nosso corpo e do lugar em que vivemos, ajuda a manter nossa saúde. A falta de higiene contribui para a proliferação de doenças" (col. 651, vol.2 ${ }^{\circ}$ ano p.63) ou ainda, "os microrganismos são seres vivos muito pequenos [...]. Mantendo nosso corpo limpo e cuidando da higiene dos alimentos, evitamos que muitos microrganismos nos causem doenças." (col. 907, vol.2 ano, p.41).

Para os demais anos, diferentemente do segundo, há uma distribuição mais homogênea dos temas, não existindo temas que sejam abordados por todas as coleções. 
No terceiro ano, dos 22 temas mapeados, o mais frequente se refere à relação entre poluição e saúde que é abordado por seis das 11 coleções, seguido da discussão acerca da importância do consumo de água tratada e das doenças de veiculação hídrica presente em cinco coleções (gráfico 4). A frequência desses temas pode ser explicada em função do que é tradicionalmente proposto para esse ano, que diz respeito às discussões relacionadas ao tema Ambiente de maneira geral e, especialmente, seus fatores abióticos (água, ar e solo).

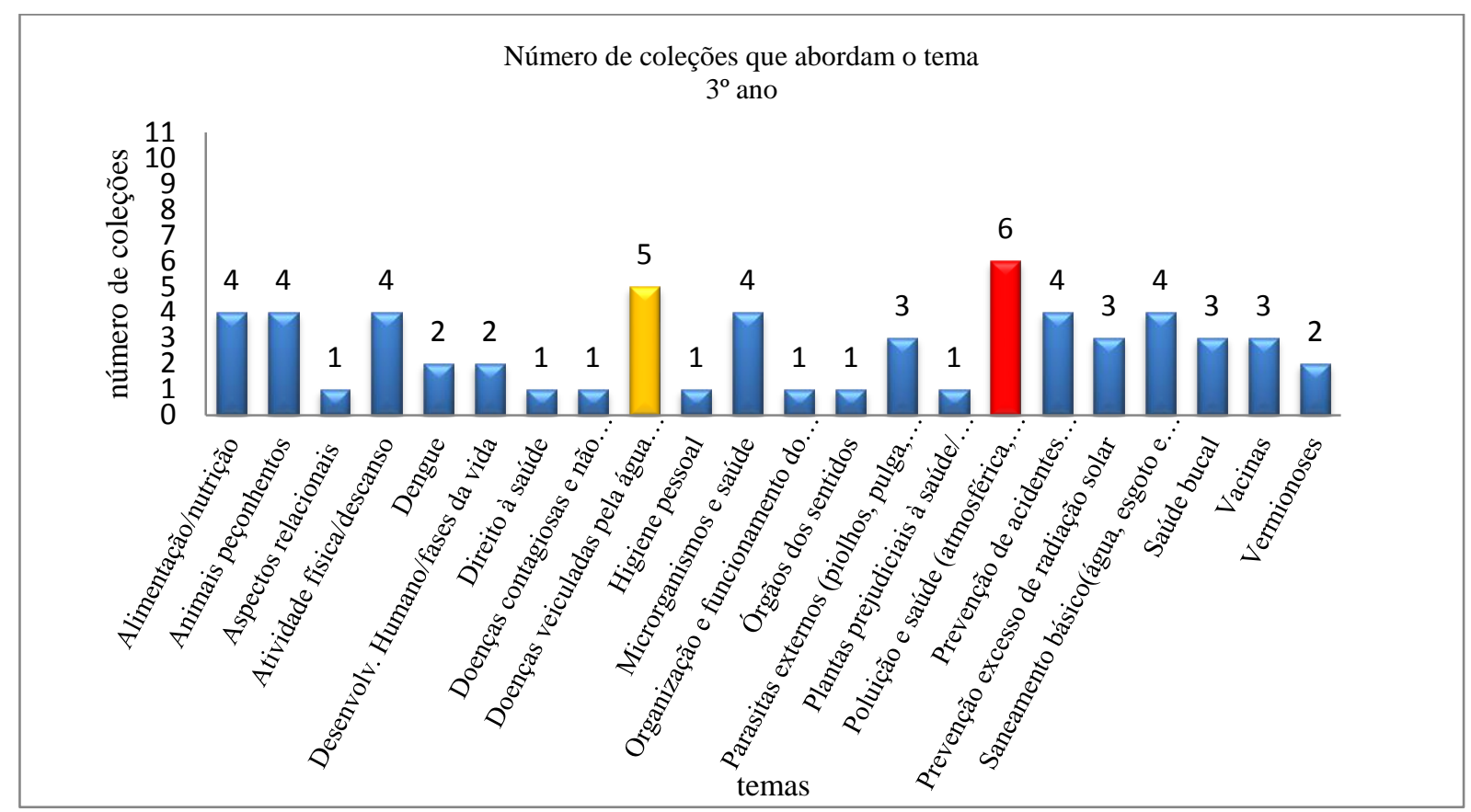

Gráfico 4: número de coleções que abordam o tema. $4^{\circ}$ ano

Nos conteúdos que dizem respeito à poluição, o foco está na discussão da ação do homem sobre a natureza e a responsabilização individual em "preservar o ambiente". Fica clara a perspectiva comportamental relacionada à saúde em expressões tais como: "jogar lixo a céu aberto causa a poluição da água, do ar e do solo, e favorece o aparecimento de doenças" (Col. 674, vol. $3^{\circ}$ ano, p.40). Além disso, algumas coleções utilizam o mote da poluição atmosférica para a discussão sobre o tabagismo (principalmente relacionada aos fumantes passivos): "A fumaça de um cigarro prejudica a saúde de quem fuma e de quem está por perto. O que você pode fazer para se proteger?” (col. 675, vol. $3^{\circ}$ ano, p.91).

No tema da água a preocupação central está na relação existente entre o consumo de água sem tratamento e o risco de doenças causadas por microrganismos. Por esse motivo, muitas coleções que desenvolvem esse tema trazem também "receitas caseiras" para o tratamento da água em locais onde não há rede de água tratada. A despeito da estreita relação entre esse fato e as condições socioeconômicas e de moradia, são poucas as coleções que 
trazem como foco essa discussão, a maior parte restringindo-se à descrição das doenças e às medidas de prevenção.

A discussão sobre o ambiente avança para o quarto ano (22 temas mapeados), onde o tema da água permanece como um dos mais frequentes, aparecendo em mais da metade das coleções (06 coleções) (gráfico 5).

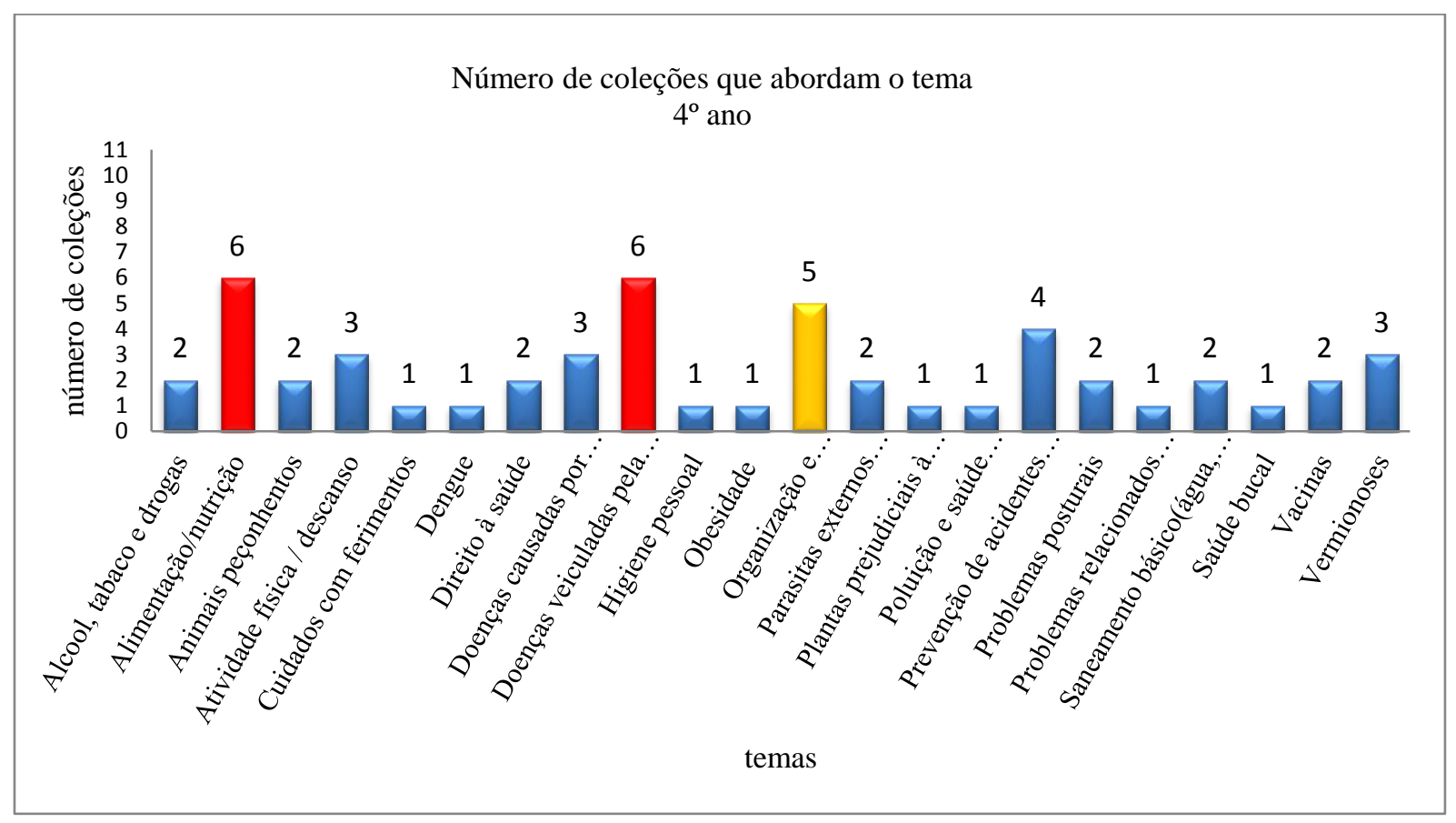

Gráfico 5: número de coleções que abordam o tema. $4^{\circ}$ ano

O foco continua sendo o mesmo, com a tendência à descrição das doenças veiculação hídrica. A seguinte atividade proposta por uma das coleções expressa esse foco: "Cada grupo [de alunos] deve buscar informações (causas, sintomas, formas de prevenção da doença, tratamento) sobre uma das doenças abaixo (Giardíase, Cólera, Leptospirose, Esquistossomose, Ascaridíase)." (col. 924, vol. $4^{\circ}$ ano, p.37).

Além disso, aparece em seis coleções a discussão sobre alimentação e nutrição. Vale ressaltar que o tema da alimentação e nutrição foi no conjunto geral dos livros analisados o tema mais frequente, aparecendo em todos os anos e em todas as coleções (muitas vezes em mais de um momento na mesma coleção), motivo pelo qual será detalhado em suas principais características quando da apresentação dos resultados relacionados às concepções de saúde.

Diferentemente do segundo ano, quando a preocupação está relacionada ao reconhecimento, por parte dos alunos, dos alimentos que mais gostam ou que mais consomem, tendo claramente o objetivo de discutir os hábitos alimentares, no quarto ano a 
ênfase está na classificação dos alimentos e na descrição de suas funções, assim como nas orientações, muitas vezes de caráter prescritivo da "dieta ideal" ou da "dieta saudável".

No quinto ano, com 27 temas mapeados, grande parte dos conteúdos relacionados à saúde diz respeito à organização e funcionamento do corpo humano: os níveis de organização e as estruturas e funções dos principais sistemas (digestório, respiratório, circulatório, musculoesquelético, excretor, reprodutor, nervoso e, em algumas coleções, regulador/endócrino). (gráfico 6).

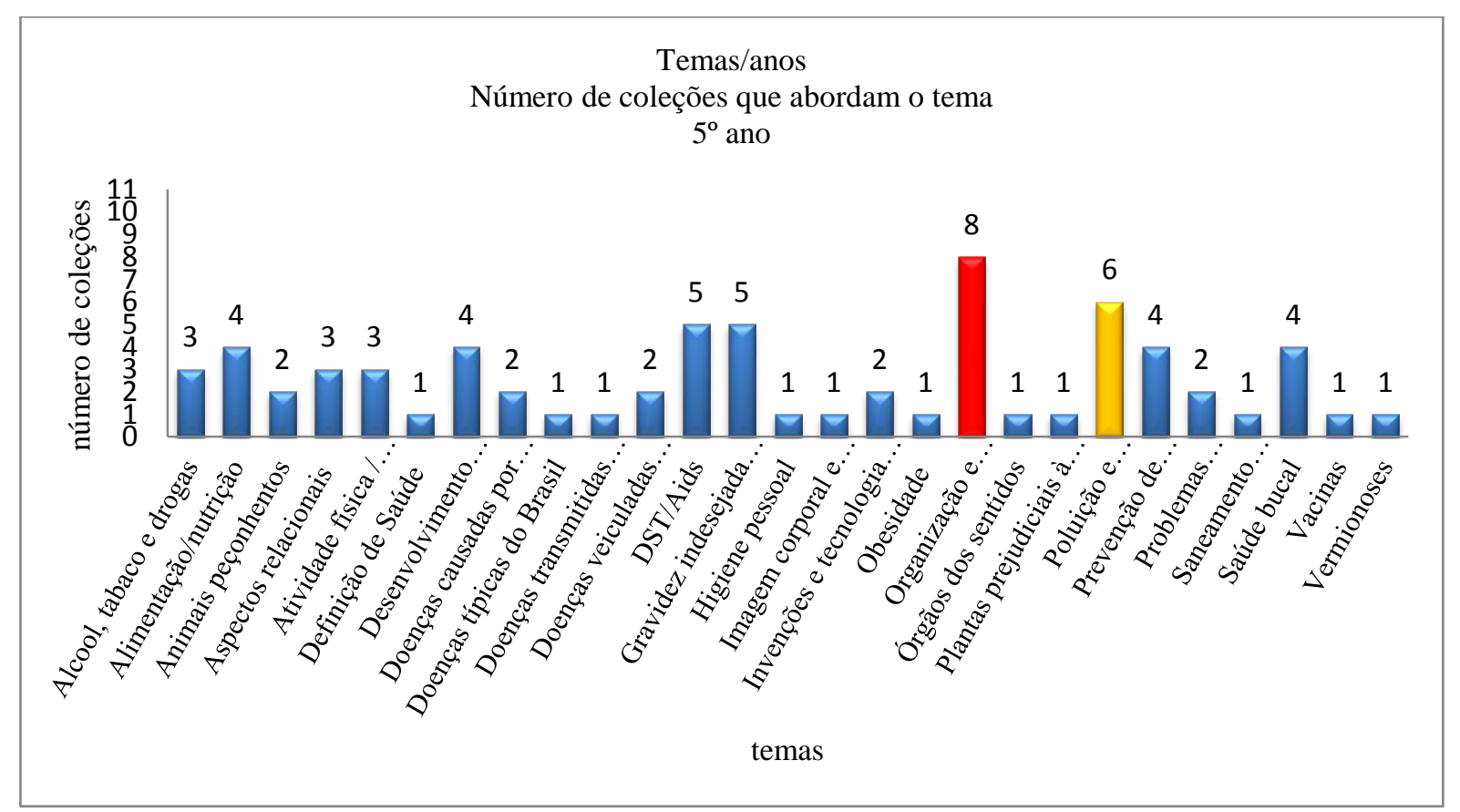

Gráfico 6: número de coleções que abordam o tema. $5^{\circ}$ ano.

Claramente o objetivo está na descrição dos sistemas e dos órgãos, como também de suas principais funções. Algumas coleções, ao apresentar os sistemas, descrevem doenças ou agravos relacionados a eles ou o uso de tecnologias de diagnóstico ou tratamento: "uma área chamada nefrologia, na medicina, estuda o funcionamento dos rins e as doenças renais. Um dos resultados desses estudos foi o desenvolvimento de um aparelho que funciona como um rim artificial, conhecido por aparelho de hemodiálise.” (col. 793, vol. 5ªno, p.120).

Além disso, o sistema digestório é utilizado como mote para a discussão acerca da alimentação e nutrição que, novamente, aparece com significativa frequência nos livros para esse ano. Em duas coleções a discussão sobre álcool e drogas está presente no contexto do sistema nervoso. 
Quando da apresentação do sistema reprodutor, aparece de forma muito heterogênea a discussão acerca da sexualidade, reprodução, DST e gravidez indesejada na adolescência. Enquanto cinco coleções abordam de maneira clara essa temática, especialmente os temas da gravidez e da prevenção às DST e Aids, outras tratam a questão da reprodução humana descolada da sexualidade. Seja por meio de sua comparação com os demais seres vivos, num processo de naturalização exacerbada da sexualidade tratando-a, portanto, como um processo apenas fisiológico, seja por uma descrição que faz com que o encontro entre o óvulo e o espermatozoide ocorra de maneira fortuita ou casual, são desconsideradas as dimensões afetivas, sociais, culturais etc. inerentes à sexualidade humana. O exemplo a seguir é emblemático dessa segunda perspectiva. Ao tratar o item "reprodução humana", uma das coleções traz o seguinte texto: "Para se formar um novo indivíduo, é preciso que as células sexuais masculinas (espermatozoides) se encontrem com as células sexuais femininas (óvulos). A união dessas células recebe o nome de fecundação ou fertilização". Nessa mesma unidade há a seguinte orientação para o professor:

caso queira comentar com os alunos, em mamíferos, aves, répteis e em algumas espécies de peixes, a fecundação acontece dentro do corpo da fêmea. Para isso, o macho e a fêmea precisam ter a relação sexual, que é o momento que o macho libera os espermatozoides no corpo da fêmea. Em várias espécies de peixes e em anfíbios, a fecundação ocorre fora do corpo da fêmea. (col. 793, vol. $5^{\circ}$ ano, p.132).

Outro exemplo é o da Coleção 611 que, ao tratar todos os sistemas do corpo humano, aborda em sessões específicas as "doenças do sistema" onde são apresentadas doenças e agravos relacionados ao sistema em questão, assim como tratamentos e uso de tecnologias (hemodiálise, transplantes, vacinas etc.). Esse modelo não é seguido apenas na apresentação do sistema reprodutor, o que pode denotar a dificuldade de abordagem do tema da sexualidade humana em sala de aula.

A partir desse mapeamento foi possível perceber que alguns temas são recorrentes em todas as coleções e em todos os anos. Chama à atenção a questão da alimentação e nutrição que aparece de forma significativa em todas as coleções e em todos os anos, retornando em diversos momentos nas mesmas coleções no decorrer desses quatro anos. Além disso, alguns temas são marcar distintivas dos anos e se caracterizam por serem abordados pela totalidade ou grande parte das coleções. Nesse conjunto, aparecem as discussões acerca dos órgãos dos sentidos e da higiene pessoal como característica do segundo ano, assim como apresentação dos órgãos e sistemas que compõem o corpo humano no quinto ano. 
A escolha desses temas parece seguir certa tradição do "currículo da saúde", na medida em que alguns são abordados de maneira sistemática por todas as coleções nos mesmos momentos, conformando determinado percurso dos conteúdos. Essa escolha, como qualquer escolha curricular, não pode ser entendida como natural ou aleatória. Está, pelo menos teoricamente, vinculada aos objetivos para o ensino da saúde, ao peso dado aos certos determinantes do processo saúde-doença em relação a outros, e fundamentalmente, a determinadas visões ou concepções de saúde.

\subsubsection{As Concepções de Saúde: distanciamentos entre o discurso e a prática}

A partir das categorias analíticas propostas, que tiveram como referência os "clássicos entendimentos sobre o tema (ALMEIDA FILHO, 2011), foi possível agrupar os diversos entendimentos e definições de saúde presentes nas coleções em cinco grandes conjuntos: saúde como ausência de doença, saúde como equilíbrio, saúde como bem-estar (na perspectiva biopsicossocial, seguindo a definição da OMS), saúde como desempenho ou função e saúde como direito. Além disso, foi possível relacioná-las a temas ou conjuntos de temas específicos. ${ }^{33}$

Essa análise procurou identificar a concepção de saúde que prevalece em cada uma das unidades, a partir da compreensão desta como um todo. Nesse sentido, buscaram-se evidências acerca de como a saúde é compreendida por meio das ênfases dadas a certos conteúdos e orientações, pela forma como esses são explorados, pelas orientações e textos de apoio destinados aos professores e por afirmações presentes nos textos que de alguma forma pudessem denotar essas concepções.

Além disso, não foi objetivo mapear os trechos no intuito de atribuir-lhes uma única concepção, na medida em que na mesma unidade de análise podem estar presentes mais do que uma concepção, não significando incoerência ou equívoco. Adicionalmente, em algumas unidades, não foi possível determinar que entendimento de saúde que norteou sua formulação. Muitas dessas unidades dizem respeito apenas à descrição de estruturas e órgãos do corpo humano, sem que seja feita qualquer menção à saúde.

\footnotetext{
33 Almeida Filho (2001) aponta ainda que a saúde pode ser compreendida como "um bem" sendo possível sua aquisição, entendimento este relacionado fortemente à ideia de produção em saúde, ligada ao conjunto de procedimentos de assistência. Dada a natureza e a função do Livro Didático, assim como a especificidade desse entendimento acerca do tema, essa concepção não foi percebida, algo que é, de certa forma, bastante esperado.
} 
Assim, os dados apresentados dizem respeito à concepção predominante em cada uma das unidades analisadas, podendo haver duplicidade, ou seja, mais de uma concepção relacionada à mesma unidade, daí a diferença entre o número total de "concepções mapeadas" e de unidades analisadas.

Nove das 11 coleções analisadas trazem, de maneira bastante evidente em seus textos de apresentação da coleção, definições de saúde, assim como definem objetivos relacionados à saúde no rol de objetivos educacionais que a coleção propõe que sejam atingidos.

Em cinco coleções, as definições de saúde se alinham à definida pela OMS relacionada à perspectiva do bem-estar, tanto na dimensão individual quanto coletiva, sob a perspectiva da saúde como um direito como, por exemplo,

a saúde [deve ser compreendida] como um direito e uma responsabilidade pessoal e coletiva, em seu sentido mais amplo, aceito pela OMS, que se refere a ela como um estado de bem-estar físico, mental e social e não meramente como ausência de doença (col. 679 , vol. $2^{\circ}$ ano, pp.50-51, orientações para os professores).

Adicionalmente, definem objetivos da seguinte natureza: "[que a criança] admita a dimensão pessoal, social e ambiental da saúde, considerando-a um projeto a ser permanentemente desenvolvido individual e coletivamente." (col. 675, vol. $2^{\circ}$ ano, p.05, orientações para os professores).

Essas coleções incorporam, nesses textos de apresentação, os determinantes culturais, socioeconômicos e ambientais como fatores que influenciam e determinam a situação de saúde dos indivíduos e grupos populacionais, como pôde ser visto no trecho a seguir: “compreendemos a saúde como um estado de equilíbrio dinâmico do corpo, condicionado por fatores biológicos, psíquicos e sociais" (col. 651, vol. $2^{\circ}$ ano, p.11, orientações para os professores) ou em afirmações como esta:

entre os inúmeros fatores que determinam as condições de saúde e qualidade de vida incluem-se condicionantes biológicos, os meios físico, socioeconômico e cultural, que expressam os níveis de ocupação e renda, o acesso à educação e ao lazer, os hábitos e formas de relacionamentos e o acesso aos serviços necessários à promoção da saúde. (col. 793, vol. $2^{\circ}$ ano, p. 12, orientações para os professores).

Três coleções apontam claramente a ideia de que a saúde é definida por um conjunto de hábitos, voltados à manutenção da saúde ou à prevenção de doenças, que devem ser adquiridos ou modificados, sendo a escola um lócus privilegiado a esse fim: "os alunos 
devem compreender a saúde como um conjunto de hábitos que favorece a manutenção do corpo e a prevenção de doenças" (col. 674, vol. $2^{\circ}$ ano, p. 05, orientações para os professores). Uma das coleções, ao justificar a presença das “dicas de saúde” no conjunto de seus volumes, aponta que

[essa dicas] apresentam textos curtos e conclusivos que visam transmitir orientações relacionadas à saúde corporal e à higiene [e caberá ao professor] incentivar a prática e o hábito do que é sugerido nessas dicas, tornando a vida dos alunos mais saudável. (col. 886, vol. $2^{\circ}$ ano, p. 22, orientações para os professores).

Uma coleção traz explicitamente a perspectiva do estilo de vida e das escolhas pessoais como definidores das situações de saúde adotando explicitamente uma perspectiva que privilegia o indivíduo. Essa coleção aponta como objetivo propiciar condições para que o aluno perceba "quanto o estilo de vida influi na saúde" e definem como papel da coleção "desenvolver um trabalho que objetiva incentivar a adoção de um estilo de vida promotor de saúde." (col. 632, vol. $2^{\circ}$ ano, p. 46, orientações para os professores).

A despeito dessa diferença existente entre elas, é possível perceber que nos seus textos de apresentação e nos objetivos propostos para o tema, o conjunto das coleções aponta para uma preocupação em tratar do tema da saúde a partir de uma visão ampliada, que incorpora aspectos de ordem social, econômica, cultural e ambiental, contemplando sua dimensão individual quanto coletiva. Há, portanto, nesses textos um alinhamento com a OMS no que tange à definição de saúde e aos PCN na definição dos objetivos para "o educar para a saúde", que apontam, entre outros aspectos, a necessidade de desenvolvimento de atitudes favoráveis à saúde, a partir de sua compreensão como um processo influenciado por aspectos de diversas ordens.

No entanto, ao analisar as unidades que desenvolvem os temas relacionados à saúde, é possível perceber que o que está definido nos textos de apresentação das coleções nem sempre é coerente com o desenvolvimento dos conteúdos. Ou seja, pode-se dizer que há um importante distanciamento entre o que é apontado como pressuposto relacionado à saúde e o é que efetivamente proposto para alunos e professores no decorrer das coleções.

Dois exemplos ilustram esse distanciamento. Uma coleção traz em sua apresentação a preocupação com a compreensão da saúde a partir de seus diversos determinantes e, no mesmo volume, apresenta nas orientações específicas de uma unidade relacionada à saúde, a seguinte afirmação: “os principais cuidados com a saúde das crianças podem ser resumidos 
em três grandes itens: higiene, alimentação e vacinação" (col. 793, vol. $2^{\circ}$ ano, p. 12, orientações para os professores), reduzindo, dessa forma a saúde à sua dimensão biológica.

Outra coleção apresenta as mesmas ideias sobre saúde em sua apresentação e desenvolve os conteúdos relacionados ao tema durante toda a coleção enfatizando os aspectos biológicos da doença a partir da dicotomia entre saúde e doença. No entanto, na última unidade do volume do $5^{\circ}$ ano (portanto, a última da coleção), denominada "Viver de modo saudável", trata as questões relacionadas à saúde de modo bastante distinto do conjunto dos demais volumes. Essa apresenta o seguinte texto em sue início:

Para ser saudável, não basta que todos os sistemas orgânicos atuem em conjunto, garantindo o bom funcionamento do corpo. Nossas emoções e nossos sentimentos também interferem na saúde do organismo. Ter bom relacionamento social, lazer e dormir bem também são aspectos importantes para a saúde. Portanto, ter saúde não significa só a ausência de doenças. (col. 886 , vol. $5^{\circ}$ ano, p.139).

Nesse caso específico, por se tratar da última unidade da coleção, pode-se inferir que há um caráter de síntese dos conteúdos trabalhados durante os anos anteriores o que aponta, de um lado, o alinhamento dessa unidade à definição adotada no volume de apresentação e, por outro, uma importante incoerência entre essa unidade e o restante da coleção.

Nas 289 unidades analisadas foram mapeadas 314 "concepções", pois, como dito anteriormente, mais de uma concepção pôde ser percebida em uma mesma unidade de análise. A tabela a seguir mostra a distribuição das concepções de saúde por coleção. (tabela 2).

\begin{tabular}{|c|c|c|c|c|c|c|c|}
\hline \multirow[b]{2}{*}{$\begin{array}{l}\text { Código da } \\
\text { coleção }\end{array}$} & \multirow{2}{*}{$\begin{array}{l}\text { Total de } \\
\text { unidades } \\
\text { analisadas }\end{array}$} & \multicolumn{6}{|c|}{ Concepção de saúde } \\
\hline & & $\begin{array}{c}\text { Ausência } \\
\text { de doença } \\
\text { ou agravo }\end{array}$ & Bem-estar & Equilíbrio & $\begin{array}{c}\text { Desempen } \\
\text { ho }\end{array}$ & Direito & Indefinida \\
\hline 611 & 38 & 23 & 9 & 3 & 3 & 2 & 0 \\
\hline 632 & 27 & 12 & 7 & 3 & 1 & 0 & 4 \\
\hline 651 & 25 & 15 & 6 & 3 & 1 & 2 & 1 \\
\hline 674 & 20 & 13 & 1 & 4 & 2 & 0 & 0 \\
\hline 663 & 16 & 10 & 1 & 1 & 1 & 2 & 1 \\
\hline 679 & 28 & 19 & 7 & 4 & 2 & 4 & 1 \\
\hline 675 & 26 & 14 & 7 & 5 & 0 & 3 & 1 \\
\hline 793 & 29 & 18 & 2 & 5 & 2 & 1 & 2 \\
\hline 886 & 28 & 17 & 2 & 6 & 1 & 1 & 1 \\
\hline 907 & 23 & 15 & 3 & 7 & 2 & 1 & 0 \\
\hline 924 & 29 & 17 & 4 & 3 & 4 & 0 & 2 \\
\hline \multicolumn{2}{|c|}{ Total por concepção } & 173 & 49 & 44 & 19 & 16 & 13 \\
\hline
\end{tabular}

Tabela 2: distribuição das concepções de saúde por coleção 
Para o conjunto das coleções, novamente considerando as diferenças existentes entre elas e a despeito dos textos de apresentação acima analisados, a saúde é entendida como ausência de doença em mais da metade dos trechos analisados, sendo essa concepção, por grande margem, a hegemônica, na medida em que cerca de 55\% das concepções mapeadas se enquadram nesse entendimento (gráfico 7).

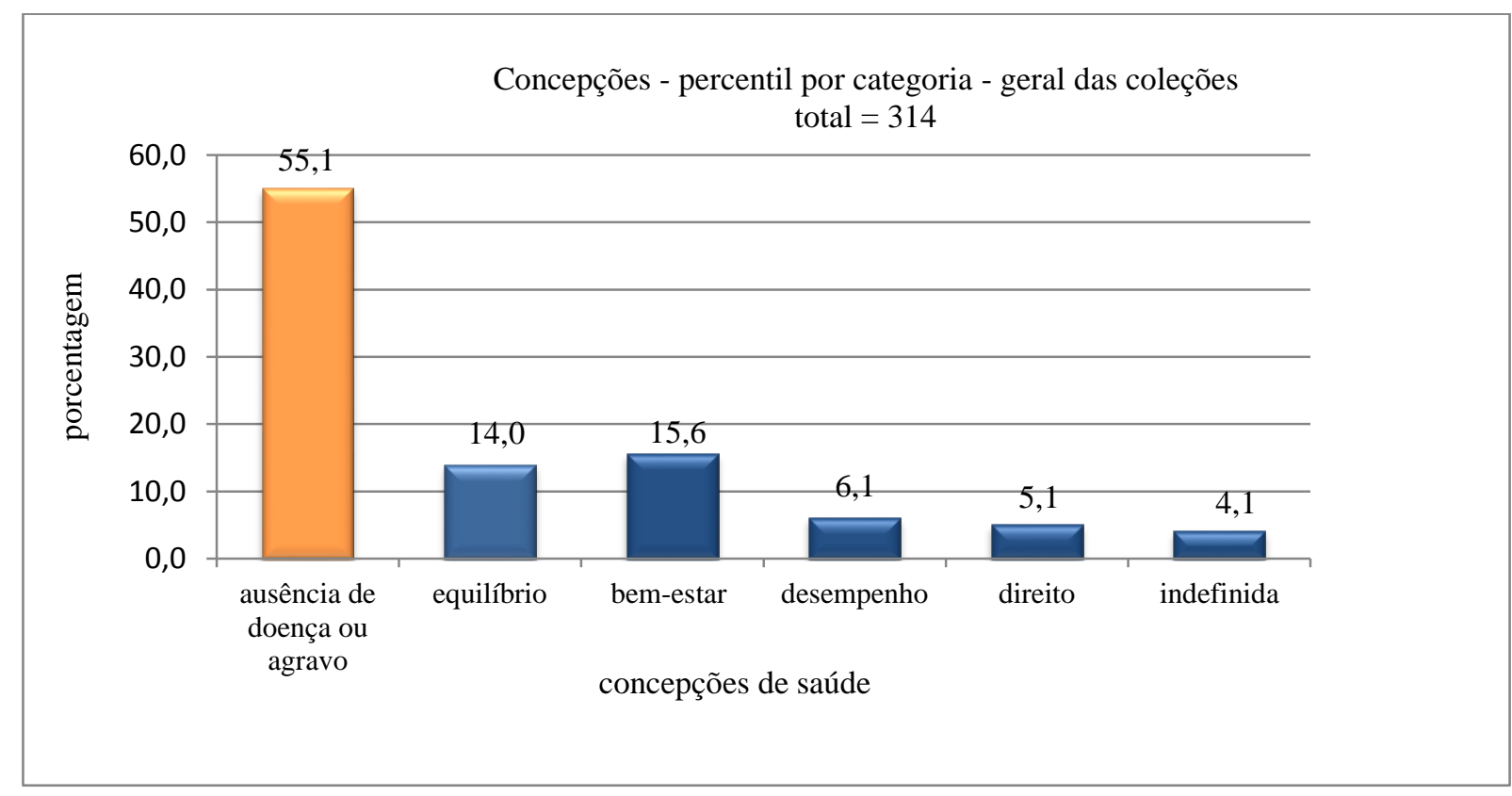

Gráfico 7: concepções de saúde: percentil por categoria. Total das coleções

Como será aprofundada adiante, essa ideia de saúde como ausência de doença ou agravo é profundamente coerente com os fatores mais enfatizados como determinantes ou condicionantes da situação de saúde, com os objetivos propostos para o ensino do tema e com a maneira pela qual os conteúdos são apresentados e desenvolvidos no conjunto das coleções.

Como exemplo dessa concepção, é possível citar duas coleções que têm unidades intituladas “Água e Saúde”, mas que tratam basicamente da descrição de doenças veiculadas pela água ou por vetores que necessitam de água para sua reprodução (leptospirose, esquistossomose, dengue e cólera) (cols. 651 e 907). Essas doenças são apresentadas a partir da descrição do seu agente etiológico, dos meios de transmissão, dos sintomas e das atitudes de prevenção. Além disso, a coleção 907 utiliza a mesma lógica na unidade sob o título de "Solo e Saúde", onde a descrição do tétano é utilizada para discutir os riscos à saúde relacionados ao solo contaminado. A ênfase, portanto, está nos aspectos biológicos e naturais da relação entre o agente e o hospedeiro a partir das condições ambientais (tríade epidemiológica), adotando uma perspectiva de ensino centrado na doença, marca do modelo 
biomédico. Assim, nessas coleções, a relação entre água e saúde (título das unidades) se dá pela descrição de doenças de veiculação hídrica, ou seja, ao se propor a falar de saúde, fala-se da doença.

Outro exemplo emblemático aparece em uma unidade que, ao trabalhar o reconhecimento dos sintomas das principais doenças da infância (no caso a gripe), apresenta uma situação em que um aluno (Pedro) está gripado e entra na sala de aula. A partir dessa situação propõe a seguinte questão: “O que poderá acontecer às crianças da classe de Pedro que estão saudáveis?". Tem como resposta esperada a essa questão a seguinte afirmação "elas podem ficar doentes." (col. 886, vol. $2^{\circ}$ ano, p.33).

Além disso, a dicotomia entre saúde e doença é o tom quando o objetivo da unidade analisada diz respeito à discussão sobre cuidados específicos e medidas de prevenção, que se constituem como objetivo para maioria das unidades. Nessas unidades enfatiza-se o conhecimento sobre a doença ou sobre o agravo no intuito de indicar ou prescrever atitudes favoráveis à saúde. Sejam elas relacionadas aos hábitos alimentares, aos hábitos de higiene pessoal, aos cuidados com o ambiente, aos cuidados de prevenção contra acidentes em casa e no trânsito, à vacinação como principal estratégia de prevenção para determinadas doenças, à atividade física ou atitudes saudáveis, dentre outros, essas unidades partem do conhecimento da doença para discutir a saúde, partem da ideia de que o "ser saudável" é aquele que "não é doente".

Foi possível perceber que as demais concepções (desempenho, equilíbrio, direito e bem-estar) aparecem no geral das coleções, mesmo levando-se em conta as diferenças entre elas, relacionadas a temas ou conjuntos de temas bastante específicos.

Via de regra, a saúde é entendida como equilíbrio quando do desenvolvimento dos temas relacionados à alimentação e nutrição, que partem do pressuposto de que uma dieta equilibrada é um importante fator de manutenção da saúde. “As doenças indicam um desequilíbrio em nosso corpo ou entre ele e os outros componentes do ambiente [...] uma alimentação equilibrada promove também a resistência do corpo às doenças" (col. 679, vol. $5^{\circ}$ ano, p.163); “a alimentação equilibrada e adequada não é um fator importante apenas para o crescimento, mas sim, para a manutenção da saúde do corpo, em qualquer fase da vida" (col. 907, vol. $2^{\circ}$ ano, p. 37, orientações para os professores) ou "a alimentação adequada e equilibrada é fundamental para a manutenção da saúde" (col. 674, vol. 4ªno, p.140), são exemplos dessa perspectiva que perpassa os quatro anos analisados. 
Ao tratar do tema, tais unidades definem como objetivo a aquisição ou mudança dos hábitos alimentares dos alunos: "[a unidade tem por objetivo] criar oportunidade para os alunos se conscientizarem mais do que comem e para fomentar o desenvolvimento de hábitos alimentares saudáveis" (col. 632, vol. $3^{\circ}$ ano, p.62, orientações para os professores).

O tema da alimentação, como já dito, é o mais recorrente nas coleções analisadas e, nesse sentido, foi possível perceber alguns aspectos que são comuns ao conjunto dos livros, assim como diferenças importantes entre eles.

Em comum está o fato de que o desenvolvimento do tema está vinculado à aquisição ou mudança de hábitos relacionados à alimentação. Seja no que tange às escolhas dos alimentos, seja relacionados aos cuidados de higiene e às informações que constam nos rótulos (prazos de validade, informações nutricionais etc.), o objetivo está sempre voltado à mudança do hábito alimentar dos alunos.

O tema aparece marcadamente em dois momentos desse ciclo de escolaridade. Num primeiro (principalmente nos livros para o $2^{\circ}$ ano), as discussões acerca da alimentação encontram-se no contexto relacionado aos órgãos dos sentidos - paladar - e são voltadas à percepção dos alunos sobre sua própria alimentação, que alimentos gostam ou consumem mais: "[a unidade tem por objetivo] identificar e questionar os próprios hábitos alimentares" e "criar oportunidade para que os alunos se conscientizem mais do que comem e para fomentar o desenvolvimento de hábitos alimentares saudáveis" (col. 632, vol. $3^{\circ}$ ano, pp. 52 e 62); ou ainda, “o que você mais gosta de comer?" e "o que [tipo de alimento] a turma precisa comer mais. O que precisa comer menos? Quais os alimentos que estão faltando nas refeições que você faz na escola?" (col. 679, vol. $2^{\circ}$ ano, pp. 90 e 93), são exemplos de atividades que têm esse propósito.

Posteriormente, o tema reaparece no contexto relacionado ao aparelho digestório $\left(4^{\mathrm{o}} \mathrm{e}\right.$, especialmente, $5^{\circ}$ ano), com ênfase para a classificação alimentar e função dos alimentos utilizando, muitas vezes, a pirâmide alimentar para ilustrar e prescrever a "dieta saudável”. Alguns exemplos ilustram essa perspectiva: "o que é necessário mudar no seu dia a dia para atender às recomendações da pirâmide alimentar" (col. 632, vol. $5^{\circ}$ ano, p. 81); "uma dieta é saudável e equilibrada quando contem todos os grupos de nutrientes na proporção adequada" (col. 924, vol. $4^{\text {o }}$ ano, p.84); "a pirâmide alimentar serve de orientação para uma alimentação saudável, isto é, equilibrada (col. 886, vol. $4^{\circ}$ ano, p.10) e "sem a vitamina A, a pessoa enxerga mal. Obtemos essa vitamina quando comemos queijo, ovos [...], sem a vitamina $\mathrm{C}$, as gengivas sangram, os dentes caem e a pessoa enfraquece." (col. 663, vol. $4^{\circ}$ ano, p.48). 
A despeito dessa similaridade dos momentos, as coleções são heterogêneas quanto à incorporação dos aspectos socioeconômicos, culturais e regionais na discussão acerca da alimentação.

Oito coleções pouco abordam esses aspectos e enfatizam a dieta saudável como uma questão relacionada basicamente às escolhas pessoais e estilos de vida, o que imprime um forte caráter prescritivo às orientações e responsabiliza os sujeitos por sua "boa" ou "má" alimentação. Afirmações como "as crianças precisam comer de três a quatro porções de frutas por dia" (col. 907, vol. $3^{\circ}$ ano, p.16); "deve-se incluir, diariamente, alimentos ricos em fibras e de fácil aceitação (col. 674, vol. $5^{\circ}$ ano, p.140), ou ainda, "para uma alimentação saudável é necessário seguir a pirâmide alimentar. O que é necessário mudar no seu dia a dia para atender às recomendações da pirâmide alimentar?" (col. 632, vol. $5^{\circ}$ ano, p.78), que aparecem desarticuladas das discussões sobre o acesso, o custo e as possibilidades dessa dieta “desejável”, são exemplos dessa perspectiva.

Por outro lado, três coleções abordam o tema a partir do contexto em que os alunos estão inseridos, incorporando aspectos de diversas naturezas.

A coleção 651 tem como fio condutor da discussão do tema da alimentação e nutrição a tentativa de desmistificação da relação entre a alimentação saudável como aquela mais cara. Nesse sentido, a preocupação com o custo dos alimentos e o incentivo ao consumo de alimentos disponíveis e possivelmente mais acessíveis aos alunos está presente em toda a coleção: "Uma boa alimentação é aquela que contém elementos nutritivos [...] comer bem não é comer alimentos caros, mas alimentos que fazem bem à saúde.” (col. 651, vol. $2^{\circ}$ ano, p.58) ou "nem todas as pessoas têm uma alimentação variada e saudável. Pesquise por que isso acontece e indique algumas soluções” (p.60). Nas orientações para os professores específicas dessa unidade:

explique a eles [os alunos] que muitas pessoas não se alimentam bem porque não têm condições econômicas de comprar comida (na quantidade e na variedade necessárias) ou porque comem em excesso determinados tipos de alimento. A falta de informação, a pobreza e o desperdício são algumas das causas da má alimentação. (col. 651, vol. $2^{\circ}$ ano, p. 32, orientações para os professores).

A coleção 679 aborda a saúde de maneira geral a partir da perspectiva do direito nos seus quatro volumes (incluída aí a questão da alimentação): “Algumas crianças não comem o suficiente; com fome, não existe saúde" (vol. $2^{\circ}$ ano, p.88) e "usando alimentos de cada lugar, dá para preparar uma refeição gostosa e boa para a saúde" (vol. $2^{\circ}$ ano, p.89), são exemplos 
dessa perspectiva. Ao orientar os professores para o desenvolvimento do tema da alimentação enfatiza que "em razão das diferenças socioeconômicas e culturais no Brasil, [o desenvolvimento do tema] impõe um olhar atento para as necessidades e os hábitos da comunidade em que a escola está inserida" (vol. $2^{\circ}$ ano, p.53, orientações para os professores). Claramente, há a preocupação com os contextos em que os alunos e suas famílias estão inseridos, assim como com os aspectos culturais e regionais presentes na alimentação.

Por fim, a coleção 675, principalmente no volume para o quinto ano, enfatiza a relação entre as condições socioeconômicas, o direito à alimentação e o papel da sociedade e do estado no que tange à garantia dos direitos constitucionais: "Apesar do que diz a constituição [artigo 227, citado anteriormente], muitas crianças brasileiras passam fome. Por que isso acontece?" (vol. $5^{\circ}$ ano, p.59). Nas orientações para os professores é definido como objetivo da unidade a compreensão de que "todos os brasileiros têm direito a uma alimentação saudável" (vol. $5^{\circ}$ ano, p.62, orientações para os professores) e há o destaque para a seguinte afirmação:

Há uma estreita relação entre alimentação e a situação econômica, hábitos culturais e recursos do ambiente, de modo que é difícil prescrever uma dieta universalmente adequada [...]. Muitas famílias não têm como oferecer às suas crianças uma alimentação saudável porque não têm acesso a emprego ou não recebem o suficiente para suprir suas necessidades básicas. Esse problema se deve à falta de equidade na distribuição da riqueza. Cabe, então, à sociedade e ao Estado fazer valer o que estabelece a constituição. (vol. $5^{\circ}$ ano, p.74, orientações para os professores).

Há, portanto, a clara intenção de apresentar a questão da alimentação não apenas como uma escolha por certo tipo de alimento em detrimento de outros, mas sim relacionada a aspectos de ordem social e como um direito que deve ser garantido pela sociedade como um todo.

A saúde aparece como desempenho basicamente na apresentação dos temas relacionados aos órgãos dos sentidos e às estruturas, órgãos e sistemas do corpo humano.

Quanto aos órgãos dos sentidos (conteúdo característico do $2^{\circ}$ ano), é muito recorrente o objetivo de utilizar essa discussão como mote para a detecção de possíveis deficiências, com especial atenção à visão e audição, tanto pelos próprios alunos, quanto pelo professor: "se você perceber algum problema de visão converse com um adulto e procurem um oftalmologista" (col. 611, vol. $2^{\circ}$ ano, p.146); "será que você precisa usar óculos? Para saber isso, é bom consultar um profissional especializado no assunto” (col. 632, vol. $2^{\circ}$ ano, p.140), 
são exemplos dessa preocupação. Além desse aspecto de verificação de possíveis deficiências, nessa discussão aparece como tema relacionado à saúde a questão da inclusão de alunos com necessidades especiais, em especial a utilização do método braile e da Língua Brasileira de Sinais (LIBRAS). Nesse sentido, é possível dizer que essa associação do tema da inclusão como um tema relacionado à saúde (e não relacionado aos direitos de cidadania, por exemplo) afirma claramente essa concepção de saúde como desempenho, e consequentemente a deficiência (ou disfunção) como não saúde.

Quanto à apresentação dos sistemas, exemplos como "ter saúde é ter o corpo e a mente funcionando bem. Quando estamos saudáveis, temos vontade de brincar, de aprender, de comer e de conviver com as outras pessoas" (col. 924, vol. $3^{\circ}$ ano, p.127) apontam que a saúde é compreendida como "o bom funcionamento" do corpo e este "bom comportamento" se reflete em atitudes observáveis. Outro exemplo é dado pela coleção 886 que, ao apresentar a unidade relacionada à organização do corpo humano, faz a seguinte afirmação "para que nosso organismo seja considerado saudável e funcione de forma equilibrada e harmônica, todos os sistemas devem exercer suas funções de maneira integrada." (vol. $5^{\circ}$ ano, p.107).

Algumas coleções (cols. 611 e 793, de maneira explicita) apresentam, nesse contexto, tópicos relacionados às "doenças do sistema" - entendidas como disfunção, ou seja, o corpo funcionando mal - e o uso de tecnologias (diagnóstico por imagem, exames laboratoriais, tratamentos, transplantes e vacinas) para relacionar o conteúdo voltado aos órgãos e sistema ao tema transversal saúde.

Um número significativo das unidades relacionadas a esse contexto tem seu foco apenas na apresentação e descrição anatômica e fisiológica dos órgãos e sistemas, sem relação direta com a saúde, a não ser em função do conhecimento, por parte dos alunos, do funcionamento do próprio organismo.

A ideia de saúde como bem-estar, a partir da perspectiva biopsicossocial, está basicamente relacionada à discussão de um conjunto atitudes e comportamentos considerados como saudáveis (dormir bem, prática de atividades físicas, aspectos relacionais, cuidado com o ambiente, dentre outros), como ilustrado pelos exemplos a seguir:

Segundo a declaração dos direitos humanos, todo o ser humano tem direito à saúde e ao bem-estar. O bem-estar físico e mental, além do bom relacionamento com outras pessoas e com o ambiente, contribui para que o ser humano tenha boa saúde. (col. 611, vol. $3^{\circ}$ ano, p.135); 
ou "uma noite bem dormida faz a gente se sentir 'novo': mais atento, saudável e de bom humor [...]. De fato, as pessoas que dormem pouco ou mal ficam doentes com mais facilidade" (col. 674, vol. $5^{\circ}$ ano, p.177), ou ainda a extensa listagem de hábitos considerados como saudáveis existente em uma das coleções (col. 886, vol. $5^{\circ}$ ano, p.139).

Por fim, a concepção de saúde como direito aparece com mais ênfase quando relacionada aos fatores ambientais, e em algumas coleções, relacionada ao tópico vacinação ${ }^{34}$. É interessante destacar que, quando relacionado aos aspectos ambientais, é bastante comum o direito à saúde estar vinculado ao direito ao saneamento básico (água, esgoto e lixo) em unidades ou capítulos que têm como objeto principal o ambiente e a apresentação de seus fatores abióticos (água, solo e ar) e não nas unidades que dizem respeito aos temas específicos relacionados à saúde. Nessa perspectiva, o direito à saúde pode ser entendido como uma consequência do direito ao saneamento e do cuidado com o ambiente, parecendo haver certa inversão entre eles.

Essa inversão fica clara no exemplo a seguir. O capítulo intitulado "Ambiente: água" da coleção 651 divide-se em duas unidades (“Água tratada e Saneamento” e “Água e Saúde”). Na primeira unidade, o livro traz a seguinte afirmação: “O acesso à água tratada é um direito de todos [...], quando a água consumida não é tratada, as pessoas correm o risco de usar água de má qualidade e ter problemas de saúde" (col. 651, vol. $3^{\circ}$ ano, p.79), estabelecendo, dessa forma, a relação entre a falta de acesso à água tratada e problemas de saúde decorrentes da presença de microrganismos. A unidade seguinte, intitulada “Água e Saúde”, onde em tese deveria ser abordada a relação entre água e saúde, não apresenta nenhuma discussão entre essa relação do direito ao saneamento como estratégia relacionada ao direito à saúde, restringindo-se a abordar as doenças de veiculação hídrica.

Alguns outros exemplos nos quais o direito à saúde é tratado no contexto "ambiente", relacionado ao direito ao saneamento e água tratada podem ser vistos nos trechos a seguir: "você acha que receber água encanada e tratada é direito de todos?" (col. 675, vol. $3^{\circ}$ ano, p.117); "todos os cidadãos têm direito a esses serviços [de saneamento]. [...] em lugares sem saneamento a água é despejada a céu aberto ou em córregos. As consequências dessas atitudes são muito preocupantes, pois representam risco à saúde." (col. 886, vol. $3^{\circ}$ ano, p.97) e

\footnotetext{
${ }^{34}$ Vale destacar o fato de que a coleção 679 adota a perspectiva da saúde como direito como fio condutor de todos os volumes e como norteadora de diversas discussões, podendo ser considerada uma exceção no conjunto analisado.
} 
nossa saúde depende muito da qualidade do ambiente em que vivemos [...]. É dever do governo cuidar da saúde e do bem estar da população. Cabe ao governo adotar medidas para evitar a poluição do ar, da água e do solo. Essas medidas fazem parte do que se chama saneamento básico. [...] é um direito também ter acesso ao saneamento básico. (col. 663, vol. $5^{\circ}$ ano, p.128).

O fato de o direito à saúde estar presente nos livros didáticos atrelado à ideia de direito ao saneamento básico e, especialmente, por aparecer em capítulos que têm como foco o ambiente, parece apontar para a ideia de que o direito ao saneamento parece ter um fim em si mesmo. A partir dessa perspectiva, o direito ao saneamento básico, dado que parece ter um sentido próprio muito mais relacionado à preservação ambiental, não aparece como uma estratégia para a garantia de um direito mais amplo, ou seja, o direito à saúde, daí a inversão a que nos referimos. A saúde, portanto, é vista como uma decorrência do saneamento e não como seu objetivo central.

O tema da vacinação aparece em diversos momentos desse ciclo, em contextos e momentos específicos. No segundo ano, quando da discussão acerca da saúde de modo geral e das atitudes favoráveis à prevenção de doenças; em num segundo momento relacionado aos conteúdos que dizem respeito à classificação animal, quando da discussão de microrganismos e; no quinto ano, relacionado ao sistema nervoso, quando da discussão de doenças do sistema, relacionado à poliomielite.

É no caso dos conteúdos relativos à vacinação que a saúde aparece mais claramente como um direito, na medida em que diversas coleções afirmam o caráter gratuito e universal da cobertura vacinal, "todo brasileiro recém-nascido tem o direito de receber a Caderneta de Saúde, [...] os postos de saúde oferecem, gratuitamente, as vacinas do calendário básico de vacinação durante o ano todo" (col. 793, vol. $5^{\circ}$ ano, p.31). Nesse contexto, oito das onze coleções analisadas tomam o tema como mote para a verificação do calendário vacinal dos alunos, o que afirma novamente o caráter universal do acesso às vacinas estabelecido por direito: "Você tem em casa seu cartão de vacinação? Suas vacinas estão em dia?" (col. 651, vol. $2^{\circ}$ ano, p.64); “consulte sua carteira de vacinação e confira: suas vacinações estão em dia?” (col. 632, vol. $2^{\circ}$ ano, p.81) e “a poliomielite refere-se a uma infecção do sistema nervoso, o que causa paralisia de um ou mais músculos do corpo. Você já tomou alguma vacina semelhante a essa [Sabin]?” (col. 907, vol. $2^{\circ}$ ano, pp.50-51), são alguns exemplos dos muitos encontrados nas coleções.

Vale destacar que é no tema das vacinas, e justamente por estar relacionado ao direito das crianças à vacinação, onde o Sistema único de Saúde (SUS), entendido como instrumento 
que visa garantir o direito ao acesso à assistência à saúde por parte da população, aparece com mais relevância e uniformidade no conjunto dos livros analisados.

\subsubsection{Os determinantes do processo saúde-doença. Hábitos e estilo de vida: o indivíduo responsável por sua saúde}

Ao analisarmos os determinantes do processo saúde-doença procuramos investigar como os fatores que influenciam a situação de saúde das pessoas ou grupos populacionais aparecem nas coleções. Partimos do pressuposto de que as coleções assumem a ideia de que a saúde deve ser compreendida como um processo influenciado por fatores de diversas naturezas, dado que esse pensamento é relativamente uniforme nas coleções, na medida em que explicitado nas suas apresentações, mesmo considerando as diferenças existentes entre as coleções e o distanciamento entre esse discurso e o desenvolvimento propriamente dito das unidades, como analisado anteriormente.

Como no caso das concepções, o objetivo não foi apontar apenas um fator para cada unidade e, nesse sentido, a presença de mais de um determinante em uma mesma unidade analisada nos parece bastante pertinente. Assim, mesmo havendo a possibilidade de mais do que um determinante estar relacionado a uma mesma unidade, procuramos apontar aquele ou aqueles que aparecem com maior relevância ou evidência em relação aos demais. A partir dessa lógica, foi possível apontar 358 fatores determinantes da situação de saúde nas 289 unidades analisadas.

Tomados os referencias apresentados no capítulo dois, que apontam que as distintas compreensões de como se dá o processo saúde-doença atribuem diferentes papéis e "pesos" que os fatores têm na determinação da situação de saúde dos indivíduos e da população, a análise das unidades dos livros didáticos mostrou ser possível agrupar esses fatores (ou determinantes) em quatro grandes conjuntos: fatores biológicos/fisiológicos, fatores ambientais (naturais ou não), aspectos sociais de caráter coletivo e fatores relacionados ao comportamento individual.

Ao serem agrupados nos conjuntos acima propostos, os fatores que influenciam a situação de saúde aparecem nas unidades analisadas do seguinte modo: fatores comportamentais 55\% (196), biológicos/fisiológicos 19\% (68), sociais de caráter coletivo 13\% (48), ambientais 6\% (20) e, unidades onde não há a discussão acerca dos fatores determinantes $7 \%$ (26). Chama à atenção a expressiva predominância dos aspectos 
comportamentais, que aparecem em mais da metade das unidades analisadas, enquanto que os demais fatores aparecem com porcentagens inferiores a 20\% (gráfico 8).

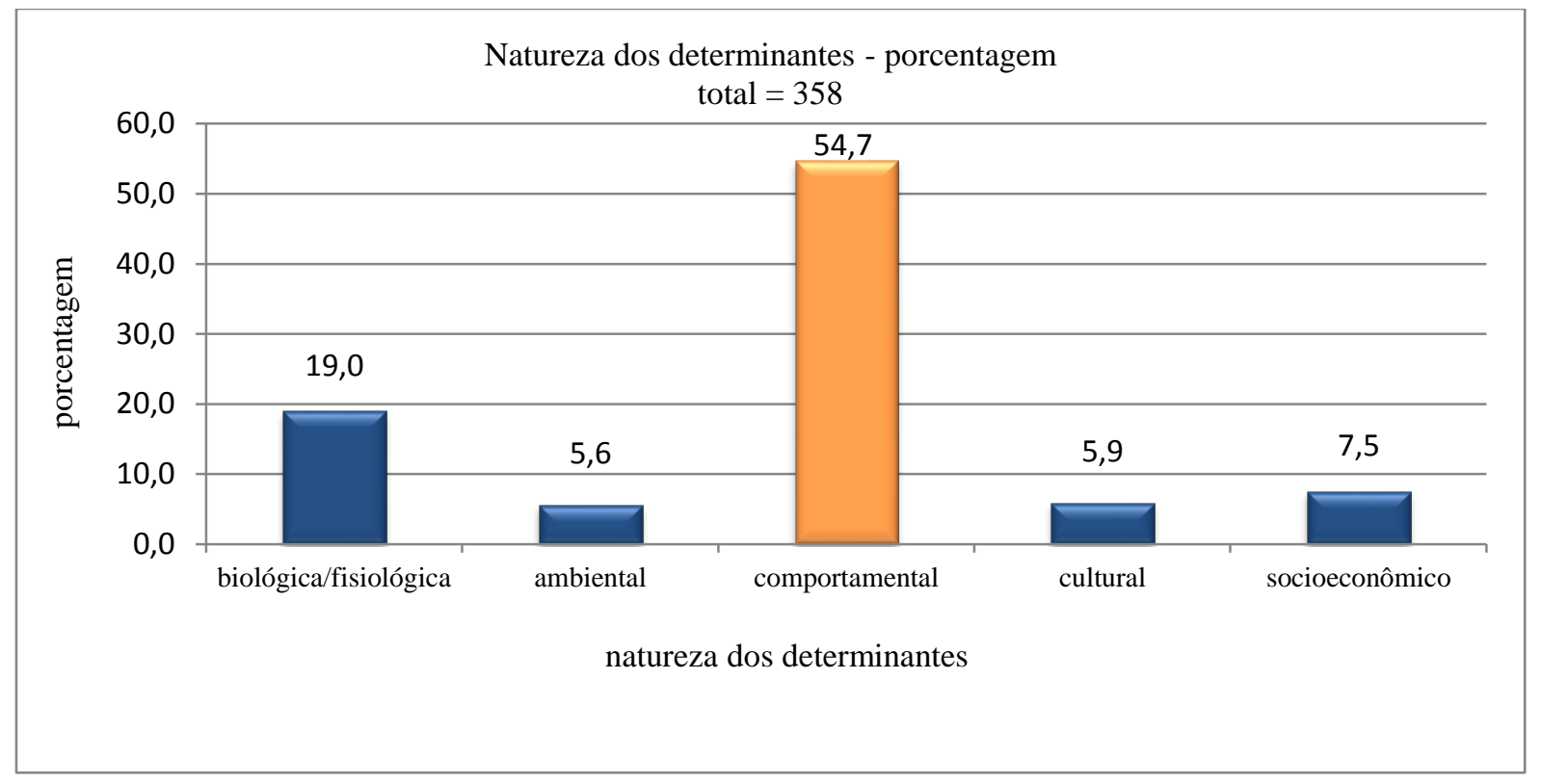

Gráfico 8: percentual dos determinantes por sua natureza. Geral das coleções

No primeiro conjunto, estão as unidades em que os fatores biológicos e/ou fisiológicos são o foco das discussões. São unidades em que a situação de saúde aparece como relacionada à presença de agentes etiológicos (vírus, bactérias, fungos, parasitas internos e externos) ou a disfunções ou deficiências do organismo. Essas unidades tratam a questão de saúde a partir da clássica abordagem da descrição do agente ou da disfunção, dos sintomas da doença, dos meios de transmissão e das medidas de prevenção, profilaxia ou tratamento.

Dentre os muitos exemplos, pode-se citar uma coleção que em uma unidade aponta que "a Gripe e o resfriado são um tipo de virose, assim como sarampo, caxumba, rubéola, varicela ou catapora, hepatite, poliomielite, meningite viral e outros. Todas essas doenças são transmitidas por vírus e todas são contagiosas." (col. 886, vol. $2^{\circ}$ ano, p.34) e finaliza a unidade com a seguinte questão: “como é possível ficar doente?" tendo como resposta esperada "ser infectado por vírus, bactéria ou por vermes" (p.43). Outros exemplos, tais como “as pulgas se alimentam do sangue de aves e mamíferos e podem causar alergias e transmitir vermes e doenças" (col. 674, vol. $2^{\circ}$ ano, p.97); "os sintomas da ascaridíase são: dores abdominais, náuseas, vômito, diarreia [...]. A contaminação se dá pela ingestão de água e alimentos contaminados." (col. 651, vol. $5^{\circ}$ ano, p. 18); "quando uma pessoa tem diabetes que órgão fica doente?” (col. 679, vol. $5^{\circ}$ ano, p. 87), ou ainda a extensa lista de doenças causadas 
por vírus, bactérias e fungos presente no volume do $2^{\circ}$ ano da Coleção 663 (pp. 18 e 19), são característicos dessa a perspectiva.

Os fatores ambientais como determinantes da situação de saúde aparecem nos livros didáticos relacionados basicamente aos danos à saúde causados pela poluição atmosférica, do solo e da água.

No caso da poluição atmosférica, o enfoque está na descrição de algumas doenças ou agravos causados pela poluição. Os assuntos são abordados em unidades que tratam do tema de forma específica, vinculadas ao contexto "fatores abióticos do ambiente", basicamente no $3^{\circ}$ ano, e relacionados à apresentação do sistema respiratório, no $5^{\circ}$ ano: "o ar está poluído quando tem materiais em quantidades que podem causa doenças nos seres vivos" (col. 675, vol. $3^{\circ}$ ano, p.90); "nada menos do que oito pessoas morrem por dia em São Paulo, em decorrência da poluição atmosférica" (col. 679, vol. 5' ano, p.123) e "em razão da concentração de poluentes, o ar pode ser uma das principais causas de doenças respiratórias" (col. 793, vol. $5^{\circ}$ ano, p.106), são afirmações que exemplificam essa relação.

Além disso, algumas coleções utilizam o mote da poluição atmosférica para a discussão do tabagismo, inclusive a partir da perspectiva do "fumante passivo": "o ar que entra em nossos pulmões pode conter substâncias que fazem mal à saúde. A fumaça dos automóveis e a fumaça dos cigarros, por exemplo, contêm substâncias tóxicas ao nosso organismo" (col. 663, vol. $4^{\circ}$ ano, p.63); “O cigarro afeta até quem não fuma! O que é ser fumante passivo?" (col. 924, vol. $4^{\circ}$ ano, p.115).

Exemplos da relação entre a poluição da água e a saúde podem ser vistos da seguinte maneira: "a água poluída pode causar diversos danos à saúde do ser humano, como cólera, esquistossomose e intoxicação" (col. 611, vol. 5 ano, p. 121); "a contaminação da água por coliformes fecais pode provocar diarreias, o que pode vir a ser um sério problema de saúde." (col. 632, vol. $4^{\circ}$ ano, p.59).

É importante ressaltar que o tema da poluição, mesmo quando aborda questões relacionadas à saúde, está vinculado às unidades que têm como foco principal a preservação do ambiente e dos recursos naturais. Nesse caso, pode-se dizer que a saúde, ou os danos a ela, aparecem como resultados secundários da ação, geralmente deletéria, do homem sobre a natureza. É muito comum nessas unidades orientações sobre como preservar ou "cuidar" da natureza e sobre atitudes que devem ser tomadas para a conservação do ambiente. 
O terceiro conjunto de determinantes são aqueles relativos aos aspectos que possuem, por sua própria natureza, um caráter marcadamente coletivo. Dizem respeito, grosso modo, aos definidos como determinantes sociais do processo saúde-doença, ou seja,

as condições mais gerais socioeconômicas, culturais e ambientais de uma sociedade, relacionadas com as condições de vida e trabalho de seus membros, como habitação, saneamento, ambiente de trabalho, serviços de saúde e educação, incluindo também a trama de redes sociais e comunitárias. (BRASIL, 2008, p.13).

Nos livros didáticos analisados, esse conjunto de determinantes é o que apareceu com menor frequência e está relacionado ao acesso ao saneamento básico e ao tema da alimentação e nutrição. Além disso, duas coleções relacionam a saúde às condições de moradia e três discutem as condições ambientais prejudiciais à saúde impostas pelo trabalho infantil.

As discussões acerca do saneamento básico e do consumo de água tratada ocupam boa parte dos livros analisados e perpassam os quatro anos desse ciclo escolar. São desenvolvidas em contextos diversos, como a alimentação, a poluição, os fatores abióticos do ambiente e em unidades que têm a saúde como objeto específico. No entanto, é pouco abordada a relação entre a falta de saneamento básico e água tratada e os aspectos socioeconômicos, as condições de moradia, a questão do direito etc. que originam essa condição.

O objetivo dessas unidades diz respeito basicamente à discussão sobre a importância do consumo de água tratada e das redes de coleta e tratamento de esgoto e coleta de lixo. Nesse contexto, muitas coleções descrevem "procedimentos caseiros" para o tratamento da água destinada ao consumo, o que pode ser entendido como uma preocupação relacionada aos contextos em que os alunos estão inseridos, muitos dos quais sem acesso à água tratada ou a redes de coleta de esgoto e lixo.

Vale ressaltar o fato de que duas coleções apontam, nas, orientações para os professores, a necessidade de organização social para a reivindicação de melhores condições de saneamento relacionando, desse modo, o direito à saúde aos seus condicionantes ambientais, tanto a dimensão individual quanto coletiva, sob a perspectiva do empoderamento comunitário.

Adotando essa perspectiva, a coleção 675 afirma que

a água é um bem indispensável à vida, e sua qualidade é fundamental para a saúde das populações. Por isso deve ser distribuída igualmente para todos [...]. As pessoas que não recebem água tratada precisam aprender o que 
fazer, individualmente, para cuidar da água de que dispõem. Devem, também, se organizar para lutar, coletivamente, pelo acesso aos serviços de saneamento básico. (col. 675, vol. $3^{\circ}$ ano, p.97, orientações para os professores).

Outro exemplo dessa natureza está nas orientações para os professores da coleção 679, quando discute a relação entre a taxa de mortalidade infantil e as condições de saneamento. Nelas sugere-se a organização popular para a melhoria das condições existentes: "é importante que, mesmo diante de condições ruins de saneamento básico na comunidade escolar, [o aluno] reconheça a importância desses comportamentos e busque formas de tornálos possíveis." (vol. $2^{\circ}$ ano, p.58, orientações para os professores).

As condições de moradia como aspecto determinante de saúde aparecem como foco central da discussão em apenas um capítulo da coleção 679, que trata dos diversos fatores intervenientes na condição de saúde. Em tópico específico, a coleção traz a seguinte afirmação: "morar bem é um direito." e propõe o seguinte questionamento aos alunos: "A moradia pode ajudar as pessoas a terem saúde?" (vol. $2^{\circ}$ ano, p.133). Nas orientações para os professores específicas desse tópico, afirma que "a moradia e qualidade de vida que ela proporciona também contribuem para a promoção ou prejuízo saúde.” (vol. $2^{\circ}$ ano, p. 60, orientações para os professores). Outra coleção aborda, como exemplo, o tema da moradia no contexto de apresentação do sistema circulatório, quando discute a tradicional relação entre as condições de moradia e o aparecimento do Mal de Chagas (col. 907, vol. $5^{\circ}$ ano, p.77).

No que tange à alimentação e nutrição, assim como já discutido, apenas três coleções se preocupam em contextualizar a discussão do tema ao relacioná-la às condições reais dos alunos, assim como aos hábitos e costumes regionais, à disponibilidade de certos alimentos, ao custo e a desmistificação da ideia de que a "boa alimentação" é aquela mais cara. Ou seja, em um conjunto restrito de coleções, o tema da alimentação é abordado tomando os determinantes de natureza coletiva como objeto de estudo e reflexão por parte dos alunos. Para as demais, o foco recai na tentativa de mudança ou aquisição de hábitos ou na discussão sobre as escolhas pessoais e estilo de vida, a partir de orientações de caráter marcadamente prescritivo.

O trabalho infantil relacionado aos determinantes socioeconômicos aparece em três coleções que apontam as condições insalubres que crianças são expostas em função do trabalho em carvoarias ou como catadores de lixo. É pertinente ressaltar que essa discussão aparece em contextos bastante distintos: na apresentação do tema órgãos dos sentidos (col. 793, vol. $2^{\circ}$ ano) e em uma unidade específica de saúde da coleção 679 (vol. $2^{\circ}$ ano), quando 
da discussão da relação entre as condições ambientais insalubres das carvoarias e os danos a esses órgãos; e na discussão sobre o tratamento do lixo, no contexto ambiente, da coleção 886 (vol. $4^{\circ}$ ano) e os riscos causados pelo trabalho em "lixões".

Vale dizer que, em muitos casos, a discussão acerca dos determinantes de ordem coletiva, tanto relacionados ao acesso ao saneamento básico, como à alimentação aparece somente no material destinado ao professor, sem que haja nenhum tipo de referência no material para os alunos. Dentre os diversos possíveis exemplos, pode-se citar uma coleção que, ao trabalhar a classificação dos alimentos - a partir da descrição de suas funções no organismo e da prescrição aos alunos o que se configura como uma "dieta saudável" - afirma nas orientações para os professores que a questão da alimentação deve ser tratada com rigor “mas não pode ignorar o aspecto cultural das comunidades envolvidas" (col. 924, vol. 4 ano, p. 84, orientações para os professores). Outro exemplo ainda mais emblemático é a lógica de construção da unidade "Ambiente: água", no volume para o $3^{\circ}$ ano da coleção 675. Nesta unidade são descritas algumas doenças de veiculação hídrica, tomando como modelo a descrição do agente, da doença, dos sintomas, dos meios de transmissão e das medidas de prevenção, com especial atenção à descrição do ciclo do agente causador da esquistossomose, com a descrição de seu ciclo completo. Não há nesse material nenhuma menção acerca da relação entre as condições socioeconômicas, culturais e de acesso ao saneamento básico e a vulnerabilidade a essa doença. No entanto, nas orientações específicas dessa unidade há a seguinte orientação:

não pretendemos que a criança memorize ou descreva o ciclo representado na ilustração, mas que interprete o diagrama para relacionar a prevenção de doença com a existência de saneamento básico, com o tratamento do indivíduo doente, com os hábitos culturais, a informação e a educação das pessoas. (vol. $3^{\circ}$ ano, p. 94, orientações para os professores).

Tomando esses dois exemplos como ilustração dessa tendência, duas questões nos parecem bastante pertinentes: por que essas relações aparecem apenas no material destinado aos professores? O que justifica essa escolha? Ou ainda, como esperar que as crianças façam relações dessa natureza sem que haja no material destinado a elas qualquer menção a esse respeito ou qualquer atividade com essa proposta?

Por fim, o conjunto de determinantes que aparece largamente como o mais referenciado no geral das coleções diz respeito aos aspectos relacionados ao comportamento individual. Tendo o indivíduo como foco do trabalho, essas unidades apontam basicamente o comportamento individual como o principal fator que interfere na situação de saúde. 
Além de serem predominantes para o conjunto das coleções, os aspectos relacionados ao comportamento também são os que predominam numericamente em todas as coleções, ressaltando novamente as importantes diferenças e matizes encontrados entre elas (tabela 3).

\begin{tabular}{c|c|c|c|c|c|c|c}
\hline \multicolumn{2}{c|}{$\begin{array}{c}\text { NATUREZA DOS } \\
\text { DETERMINANTES - por } \\
\text { coleção }\end{array}$} & \multicolumn{6}{c}{ Natureza do determinante } \\
\cline { 2 - 7 } Código da coleção & $\begin{array}{c}\text { Total de } \\
\text { unidades } \\
\text { analisadas }\end{array}$ & $\begin{array}{c}\text { Biológica/ } \\
\text { Fisiológica }\end{array}$ & Ambiental & $\begin{array}{c}\text { Comportam } \\
\text { ental }\end{array}$ & Cultural & $\begin{array}{c}\text { Socioeconô ô } \\
\text { mica }\end{array}$ & $\begin{array}{c}\text { N/A - } \\
\text { indefini } \\
\text { da }\end{array}$ \\
\hline 611 & 38 & 12 & 2 & 25 & 3 & 5 & 0 \\
\hline 632 & 27 & 3 & 0 & 22 & 1 & 0 & 4 \\
\hline 651 & 25 & 4 & 1 & 19 & 2 & 4 & 2 \\
\hline 674 & 20 & 3 & 2 & 13 & 1 & 0 & 2 \\
\hline 663 & 16 & 5 & 2 & 11 & 0 & 2 & 0 \\
\hline 679 & 28 & 4 & 4 & 21 & 3 & 6 & 1 \\
\hline 675 & 26 & 2 & 1 & 21 & 4 & 3 & 4 \\
\hline 793 & 29 & 12 & 3 & 9 & 1 & 1 & 4 \\
\hline 886 & 28 & 10 & 1 & 14 & 1 & 3 & 7 \\
\hline 907 & 23 & 5 & 2 & 19 & 3 & 1 & 0 \\
\hline 924 & 29 & 8 & 2 & 22 & 2 & 2 & 2 \\
\hline Total & $\mathbf{2 8 9}$ & $\mathbf{6 8}$ & $\mathbf{2 0}$ & $\mathbf{1 9 6}$ & $\mathbf{2 1}$ & $\mathbf{2 7}$ & $\mathbf{2 6}$ \\
\hline
\end{tabular}

Tabela 3: distribuição dos determinantes analisados como preponderantes nas unidades analisadas por coleção e geral

Os livros analisados trabalham os fatores de natureza comportamental a partir de três grandes vertentes: a mudança ou aquisição de hábitos, os comportamentos voltados à prevenção de doenças e agravos específicos e a discussão sobre o estilo de vida e as escolhas pessoais consideradas saudáveis.

A ideia de que a situação de saúde é principalmente decorrente de um conjunto de hábitos e de que a escola é um local privilegiado para a aquisição ou mudança dos mesmos é bastante comum nos livros analisados, chegando a ser explicitada em algumas coleções: "os alunos devem compreender a saúde como um conjunto de hábitos que favorece a manutenção do corpo e a prevenção de doenças." (col. 674, vol. $2^{\circ}$ ano, p.05, orientação para o professor) ou "lembre-se da contribuição fundamental da escola na aquisição de hábitos de higiene" (col. 675 , vol. $2^{\circ}$ ano, p.59 e vol. $5^{\circ}$ ano, p. 68 , orientações para os professores), são exemplos desse pressuposto.

Cabe aqui lembrar que esse entendimento relacionado ao papel da escola na "criação de hábitos" ou "atitudes saudáveis" é a base das diretrizes para o ensino dos temas relacionados à saúde tanto no parecer 2.246 do Conselho Federal de Educação, de 1974, quanto dos Parâmetros Curriculares Nacionais, de 1997. 
Marcadamente, essa ideia aparece nas unidades que trabalham o tema da alimentação, que apontam entre seus objetivos pedagógicos a mudança (ou aquisição) de hábitos alimentares dos alunos, assim como já discutido anteriormente, e também naquelas em que são discutidos os aspectos relacionados à higiene pessoal (incluídas as unidades relacionadas à saúde bucal): "para evitar que os micróbios ataquem os dentes, ele [um aluno hipotético] faz a limpeza de dentro para fora" (col. 651, vol. $2^{\circ}$ ano, p.57); "quais dos seus hábitos são importantes para o bem-estar do seu corpo?", tendo como resposta esperada: "espera-se que os alunos mencionem os hábitos de higiene." (col. 632, vol. $2^{\circ}$ ano, p.69); "a palavra higiene tem origem grega e significa o que é saudável. Práticas de higiene são ações de hábitos que nos ajudam a prevenir doenças e nos manter saudáveis.” (col. 924, vol. $2^{\text {o }}$ ano, p.37).

Obviamente que ao discutirmos a ideia de hábitos, partimos do pressuposto que esses têm uma profunda relação com aspectos de caráter coletivo, tais como a cultura e os contextos onde os alunos estão inseridos, os aspectos regionais e particulares de cada grupo, o acesso aos bens e serviços etc. Portanto, ao indicarmos que o trabalho dos livros didáticos relacionado aos hábitos dos alunos está relacionado aos determinantes de natureza individual, não desconsideramos esse aspecto. No entanto, ao identificarmos que os fatores culturais, contextuais e coletivos da saúde são muito pouco explorados, podemos dizer que a discussão acerca dos hábitos tem como foco o indivíduo.

Nesse sentido, ao analisar a perspectiva relacionada à mudança de hábitos dos alunos, é possível dizer que há uma tendência à individualização e descontextualização desse trabalho, tendo como foco do trabalho principalmente, e quase exclusivamente, o indivíduo. É no conjunto de hábitos que o indivíduo possui que os livros didáticos procuram interferir.

A segunda vertente pela qual os aspectos relacionados ao comportamento aparecem como principais fatores determinantes da situação de saúde diz respeito às unidades que têm como objetivo a orientação sobre cuidados e atitudes de prevenção relacionadas a doenças ou agravos específicos. Essas unidades correspondem a 34\% do total analisado e estão presentes em todos os anos e em diversos contextos. Partem do pressuposto de que é a prevenção o objeto principal da educação em saúde: "na saúde, a prevenção é a melhor maneira de se manter saudável” (col. 674, vol. $5^{\circ}$ ano, p.58, orientações para os professores). Abordam diversos assuntos: os relacionados à prevenção de acidentes de maneira geral, aos acidentes com animais, à vacinação, aos cuidados relacionados à alimentação e ao consumo de água, aos cuidados com a limpeza das orelhas e olhos, à saúde bucal etc. 
Alguns, dentre muitos exemplos encontrados, ilustram essa preocupação: "durante uma tempestade, devemos evitar: locais descampados, procurar abrigo sob árvores isoladas, tomar banho de mar" (col. 663, vol. $5^{\circ}$ ano, p.99); "evite esfregar os olhos com as mãos, pois nelas pode haver microrganismos que causam doenças como a conjuntivite (col. 611, vol. $2^{\circ}$ ano, p. 146); "para evitar doenças é recomendável a utilização de procedimentos caseiros [de tratamento de água]" (col. 907, vol. 4ªno, p.19); "para evitar as cáries, você deve escovar os dentes após as refeições e antes de dormir" (col. 924, vol. $3^{\circ}$ ano, p. 124); "evite tomar sol sem proteção de filtros solares, principalmente no período das 10 da manhã às quatro horas da tarde." (col. 632, vol. $2^{\circ}$ ano, p.86).

Portanto, ao enfatizar a doença ou agravo específico a fim de orientar ou prescrever atitudes e condutas voltadas a sua prevenção, pode-se dizer que essas unidades baseiam-se nos preceitos preventivistas da educação em saúde que, segundo Czeresnia (2009) para atingir seus objetivos "estruturam-se mediante a divulgação de informação científica [sobre a doença e os riscos] e de recomendações normativas de mudanças de hábitos.” (p. 49). A partir dessa perspectiva, é bastante coerente que essas unidades adotem um modelo de apresentação dos conteúdos que diz respeito ao conhecimento da doença ou do agravo (seus sinais e sintomas), seus agentes etiológicos ou de risco e medidas de prevenção relacionadas aos comportamentos ou aos hábitos.

Por fim, a terceira vertente parte da perspectiva da promoção da saúde esse relaciona à ideia da adoção de um determinado estilo de vida e de determinadas escolhas pessoais como os principais determinantes da situação de saúde.

Vale retomar a discussão apresentada no capítulo referente à saúde, que aponta como principal diferença entre a perspectiva da promoção da saúde e de prevenção de doenças o fato de que a primeira tem como objeto a saúde propriamente dita (conceito "positivo" de saúde), não sendo direcionada a um agravo específico, enquanto que as ações relacionadas à prevenção são direcionadas e têm como foco uma doença ou agravo específico.

De maneira sintética, a crítica que se faz à ideia de estilo de vida dentro do próprio campo da promoção da saúde diz respeito à tendência de responsabilização e culpabilização individual, que atribui aos sujeitos a responsabilidade por sua própria saúde (CASTIEL, 2007), assim como a desresponsabilização do Estado e da sociedade como um todo pela garantia e manutenção das condições necessárias à saúde dos indivíduos e da população e pela minimização de seus aspectos deletérios (CZERESNIA, 2009). Além disso, essa perspectiva tem como foco apenas os fatores que estão ao alcance do indivíduo, deixando de 
problematizar todos aqueles de caráter coletivo que não estão sob a responsabilidade, mesmo que parcial, do próprio indivíduo (BUSS, 2000).

A perspectiva do estilo de vida está presente em muitas coleções analisadas e se relaciona a um conjunto de comportamentos que devem ser seguidos a fim de adquirir ou “conquistar” uma melhor situação de saúde de maneira geral. Os conteúdos relativos a essa abordagem dizem respeito basicamente à escolha dos alimentos considerados saudáveis; à prática de atividades físicas; aos comportamentos relacionados ao sono e ao descanso e a um conjunto de atitudes e comportamentos sociais e inter-relacionais considerados como adequados e, portanto, "saudáveis".

É pertinente ressaltar ainda, que uma das coleções explicita ser esse o principal pressuposto relacionado à saúde, ao apontar como um dos seus objetivos pedagógico que os alunos devem "aprender quanto o estilo de vida influi na saúde" e se propõe a "desenvolver [durante esse ciclo de escolarização] um trabalho que objetiva incentivar a adoção de um estilo de vida promotor de saúde" (col. 632, vol. 2 $2^{\text {o }}$ ano p. 46, orientações para os professores).

Independentemente do objeto que está sendo apresentado ou do tema em questão, fica claro nessas unidades o caráter de responsabilização do indivíduo sobre as suas condições de saúde: "para alcançarmos o mais alto grau de saúde devemos nos responsabilizar por todas as nossas ações para evitarmos acidentes." (col. 611, vol.2 ano, p. 163); "cuide bem do seu corpo [...]. Cuidar da saúde é dever de cada um.” (col. 924, vol.5 ano, p.99); “é preciso mudar alguma coisa no seu dia-a-dia para você ser uma pessoa mais saudável?" (col. 632, vol. $5^{\circ}$ ano, p.87); “então, sua alimentação diária segue as recomendações dos nutricionistas?” (col. 674, vol. $4^{\circ}$ ano, p.126); "será que a alimentação das pessoas que você convive é saudável? Compare com as orientações da pirâmide alimentar" (col. 793, vol. $5^{\circ}$ ano, p.97) e "para manter a saúde, as pessoas precisam dormir bem, na hora certa, e ter um sono tranquilo. Precisam ter cuidados com a higiene dos alimentos [...]. Além disso, têm de cuidar da higiene do corpo" (col. 663, vol. $4^{\circ}$ ano, p.121) são alguns dos muitos exemplos que ilustram essa perspectiva.

É pertinente o aprofundamento da análise de dois exemplos encontrados nas coleções que explicitam como a abordagem relacionada ao estilo de vida, aliada ao pouco destaque dado aos contextos e determinantes sociais de caráter coletivo, tende a culpabilizar o indivíduo pela sua saúde. 
Duas coleções abordam o tema da obesidade infantil em um mesmo momento da trajetória escolar ( $5^{\circ}$ ano), a partir da discussão acerca das mudanças que ocorrem na adolescência. A primeira apresenta um tópico que se propõe a discutir a relação entre corpo e sociedade. No início do módulo o autor define que "serão exploradas algumas mudanças que vêm ocorrendo com o corpo humano e que podem ser relacionadas com mudanças na sociedade" (col. 632, vol. $5^{\circ}$ ano, p.124). No entanto, é trabalhada apenas a questão da obesidade, associada à ideia das escolhas pessoais e estilo de vida: "você está contente com o corpo que tem? [...] você tem algum hábito que pode estar contribuindo para aumentar o seu peso?" 35 . Assim, boa parte da unidade é voltada à discussão sobre a influência da propaganda no consumo de alimentos que podem causar obesidade. Além disso, é proposta uma atividade de medição da circunferência abdominal dos alunos que é bastante questionável, na medida em que poderá reforçar estigmas e constrangimentos relacionados à imagem corporal que as crianças têm de si mesmas. Ou seja, a obesidade aqui é compreendida como um resultado apenas das escolhas.

Perde-se, portanto, a oportunidade de discutir padrões de beleza, busca do corpo perfeito, preconceitos, discriminações e distúrbios alimentares, por exemplo, especialmente importantes na faixa etária do ano em questão (10-11 anos) onde essas pressões ficam mais fortes. A mesma coleção propõe, em uma unidade anterior a "pirâmide de atividades físicas" que é apresentada como "outra proposta para nos ajudar a manter um estilo de vida saudável" (p. 80). Nessa pirâmide, é apresentado um conjunto de atividades físicas e sua frequência semanal desejável, dentre elas, praticar ioga, nadar, dançar na academia, dançar em festas, como se todos os alunos tivessem acesso a elas e realizá-las ou não dependesse apenas de sua vontade pessoal.

Outra coleção, ao abordar o mesmo tema, traz como preocupação as práticas danosas que podem ser realizadas em função da busca do corpo perfeito, em um tópico denominado “Perseguir a beleza pode não ser saudável." (col. 679, vol. $5^{\circ}$ ano, p.97). Nele são discutidos temas como o uso de medicamentos (anabólicos, esteroides ou redutores de apetite), a prática exagerada e sem orientação de atividades físicas, as dietas sem acompanhamento: "para ficarem bonitos como os ídolos alguns adolescentes acham que vale tudo" (p. 97). Discute

\footnotetext{
35 Aqui há também um importante equívoco, na medida em que o ganho de peso corporal é associado necessariamente ao aumento da obesidade (ou do percentual de gordura corporal). Essa relação é equivocada, especialmente quando se tratam de crianças em plena fase de crescimentos (10-11 anos), que são os alunos para os quais o livro é dirigido, pois o crescimento gera um aumento do peso, independentemente de mudanças na percentual de gordura corpórea.
} 
também a pressão dos meios de comunicação e de mídia para um determinado padrão de beleza:

Muitas vezes, a menina ou o menino se acham gordos por se compararem com os modelos de beleza que aparecem na televisão, nos desfiles de moda, nas novelas. [...]. Será que as revistas, os jornais e a televisão contribuem para que os adolescentes fiquem satisfeitos com o corpo que têm? (p. 98).

O objetivo, portanto, não é discutir a obesidade como um problema em si a ser enfrentado e "resolvido" a partir de escolhas de caráter pessoal, mas sim a interferência de padrões externos na construção da autoimagem dos alunos, e inclusive de suas escolas, mas estas contextualizadas e problematizadas.

Ou seja, a primeira coleção aborda o tema da obesidade a partir de um referencial estabelecido externamente, que reforça a ideia de que a saúde é "conquistada" por um conjunto de escolhas. Além disso, leva pouco em consideração o contexto em que estão os alunos, incorrendo, portanto, no risco de os culpabilizar por sua possível situação de saúde relacionada à obesidade (inclusive com atividades que podem exacerbar estigmas e preconceitos). Por outro lado, a segunda coleção procura abordar o mesmo tema relacionando-o ao contexto de vida dos alunos, questionando os padrões culturais externos veiculados pelos meios de comunicação, a fim de reforçar a ideia de que o bem-estar (ou a saúde, nesse caso) está muito mais relacionado à autoestima e à consciência por parte dos alunos das diferenças individuais, do que a padrões externos.

Outro exemplo que exacerba a relação da saúde com um conjunto de atitudes e escolhas entendidas como favoráveis, está relacionada aos sentimentos em relação ao outro. Uma das coleções, na unidade intitulada "Viver de modo saudável" propõe uma discussão acerca da relação entre os sentimentos e a manutenção da saúde da seguinte maneira: "na medida em que 'alimentamos' bem nossa saúde mental, com emoções positivas, bons pensamentos e momentos de lazer, melhor será nossa saúde física." (col. 663, vol. $4^{\circ}$ ano, p.116). A seguir define, de maneira bastante discutível, o termo saúde mental como "ter pensamentos e sentimentos positivos sobre você mesmo e o mundo em que vive" (col. 663, vol. $4^{\circ}$ ano, p.117). Tal relação entre a manutenção da saúde e os "pensamentos positivos" prossegue nas páginas seguintes ao afirmar que "para ter uma vida saudável não bastam apenas os cuidados com a higiene dos alimentos e do corpo. É importante também cuidar da saúde mental.” (vol. $4^{\text {o }}$ ano, p.123). 
Tomados os exemplos acima como emblemáticos, fica claro o risco de culpabilização e responsabilização do indivíduo sobre sua saúde (a saúde mental como escolha, a boa alimentação como escolha, as formas do corpo como resultado de escolhas, os momentos de lazer como escolhas, as condições de higiene e de sono como escolhas).

Concordamos com Castiel (2007) quando afirma que "existem casos em que, por motivos de privação econômica e exclusão social, não há possibilidade de escolha. Nessas situações, não faz sentido considerar as pessoas responsáveis por seus 'estilos de vida'." (p.85) e que

sustentar que o indivíduo é responsável por sua saúde é sumamente discutível no caso da pobreza. Nestas circunstâncias, não colocar os determinantes socioeconômicos, culturais e ambientais em perspectiva costuma criar o cenário para a culpabilização das vítimas. (p.38).

Adicionalmente, cabe retomar o alerta que a própria Organização Mundial da Saúde, já em 1998, para o fato de que as ações voltadas para a modificação dos estilos de vida, incluídas nesse conjunto as ações educacionais, em espaços formais ou não, só terão certo grau de efetividade forem "dirigidas não apenas ao indivíduo, mas também às condições sociais e de vida que interagem para produzir e manter estes padrões de comportamento." (WHO, 1998, p.16).

Assim, é possível dizer que, ao adotarem a perspectiva do estilo de vida, aliada ao pouco destaque aos determinantes socioeconômicos, os livros didáticos destinados aos alunos das escolas públicas nacionais, inseridos nos mais diferentes contextos socioeconômicos e culturais, inclusive de pobreza (como é o caso da amostra aqui analisada), acabam por reforçar o caráter individual, prescritivo e moralizador da saúde. Além disso, ao adotarem esse modelo acabam por reforçam a tendência de desresponsabilização do Estado e da sociedade como um todo pela garantia das condições de vida e saúde minimamente dignas dos indivíduos e da população.

É importante destacar que nos parece claro que a abordagem dos temas de saúde levando-se em conta seus aspectos sociais de caráter coletivo nem sempre é possível e adequada. No desenvolvimento de alguns temas, dada sua natureza, a incorporação desses aspectos de maneira artificializada e, em certo sentido, ingênua ou repetitiva pode ser entendida inclusive um problema epistemológico e didático.

Já em 1997, os PCN alertam para esse cuidado em abordar os diferentes fatores que influenciam a situação da saúde ao afirma que 
os enfoques segundo os quais a condição de saúde individual é determinada unicamente pela realidade social ou pela ação do poder público, tanto quanto a visão inversa, nem por isso menos determinista, que coloca todo peso no indivíduo, em sua herança genética e em seu empenho pessoal, precisam ser rompidos [no ensino dos temas relacionados à saúde].(BRASIL, 1997c, p. $65)$.

É pertinente, portanto, afirmar que não entendemos que todos os temas relacionados à saúde humana devam ser tratados a partir da perspectiva coletiva, correndo-se o risco de artificializar essa abordagem.

No entanto, é possível dizer que os determinantes coletivos, quando aparecem nos livros analisados, têm peso relativamente pequeno, se levarmos em conta o conjunto de unidades. Além disso, aparecem como tendo a mesma importância e relevância que os demais (comportamentais e naturais) fazendo parte de um mesmo conjunto.

A crítica aqui realizada recai no fato de que o conjunto de livros analisados abordam timidamente os fatores sociais de caráter coletivo como aspectos que influenciam de maneira determinante as condições de vida e situações de saúde de indivíduos e populações, relação essa que é consenso no campo da saúde (BUSS, 2000).

Concordando com Rouquaryol e Goldbaum (2003) e Barata (2005) que afirmam que os aspectos sociais não podem ser vistos como mais um dentro do mesmo conjunto dos demais (naturais, ambientais), na medida em que os primeiros influenciam e determinam os segundos, os livros didáticos acabam por naturalizar certas condições de saúde que não são naturais, mas sim historicamente constituídas, ou ainda, responsabilizar ou culpabilizar os indivíduos, e apenas eles, descontextualizados das condições materiais de existência em que vivem, por sua situação de saúde.

\subsubsection{Os objetivos: risco e prevenção}

Seguindo a mesma lógica utilizada na análise das concepções e dos determinantes do processo saúde-doença, procuramos identificar quais são os objetivos para cada um dos 289 trechos selecionados.

Na medida em que os objetivos estão intrinsecamente ligados aos conteúdos de cada uma das unidades, a análise não teve como intenção listar os objetivos relacionando-os a cada desses conteúdos, mas sim compreender sua relação com a saúde, a partir das suas intenções mais gerais. Para tanto, os dados coletados referentes às orientações para os professores tiveram destaque, na medida em que é nesses textos que os objetivos pedagógicos estão mais 
claramente expressos. Além disso, os objetivos estão diretamente imbricados ao entendimento da reação entre educação e saúde ou ainda, do papel que a educação pode desempenhar na melhoria das condições de saúde dos indivíduos e da população.

A partir dessa perspectiva, foi possível agrupar os objetivos em seis grandes conjuntos relacionados: 1) à mudança ou aquisição de hábitos (de higiene ou alimentares); 2) às orientações sobre atitudes e comportamentos considerados saudáveis, a partir da perspectiva da promoção da saúde; 3) ao autoconhecimento, por parte dos alunos, de seu próprio corpo (órgãos e estruturas); 4) ao reconhecimento das condições favoráveis e desfavoráveis à saúde ligadas ao ambiente e aos aspectos sociais, 5) às definições de saúde e, por fim; 6) às medidas de prevenção e cuidados relacionados a doenças ou agravos específicos.

Quanto aos hábitos, é bastante presente a ideia de que a escola se constitui como lócus privilegiado para o desenvolvimento e fomento de hábitos de higiene e alimentares considerados como saudáveis: "lembre-se da contribuição fundamental da escola na aquisição de hábitos de higiene" (col. 675, vol.2 ano, p. 59, orientações para os professores). Como já discutido, essa perspectiva permeia as diversas unidades que dizem respeito à alimentação e nutrição - que é o tema mais frequente no conjunto analisado -, assim como nos diversos momentos em que são apresentados procedimentos relacionados à higiene pessoal (banho, importância da lavagem das mãos, escovação dos dentes, higiene dos alimentos, limpeza dos ambientes etc.). Dentre os muitos exemplos, é possível citar os seguintes: “além de manter a casa limpa, também é preciso ajudar a cuidar da limpeza da escola, dos parques, das ruas e de outros locais públicos." (col. 611, vol. $2^{\circ}$ ano, p.179) e "a limpeza é importante para a saúde" (col. 679, vol. $2^{\circ}$ ano, p.95)

Essa ideia de aquisição ou mudança de hábitos está na base do ensino da saúde desde sua incorporação no cotidiano escolar, sendo, por exemplo, o principal objetivo a ser alcançado nos programas de saúde da década de 1970 (BRASIL, 1974). Bagnato, em 1990, chamava à atenção para os parcos resultados desses programas com relação aos hábitos dos alunos, em função de seu caráter prescritivo que levava pouco em consideração as reais condições e contextos em que os alunos estão inseridos. Segundo a autora

é importante lembrar que as mudanças de comportamentos relacionados com a higiene e a saúde não são asseguradas só pelo ensino da saúde; elas devem ser acompanhadas por condições adequadas de vida dos alunos e suas famílias e o ensino da saúde deve se dar mais em termos de discutir todas essas questões, contextualizando-as. (BAGNATO, 1990, p. 56). 
Outro conjunto de objetivos diz respeito à orientação acerca de atitudes e comportamentos que visam à promoção da saúde de maneira geral, sem que seja especificada a doença ou agravo específico.

Nesse conjunto aparecem principalmente as orientações acerca do lazer, da prática de atividades físicas e descanso: "o lazer e a atividade física, combinados com uma alimentação saudável e repouso, contribuem para a saúde” (col. 651, vol. $3^{\circ}$ ano, p.18); “dormir é necessário para crescer com saúde, pois é principalmente durante o sono que o corpo das crianças se desenvolve." (col. 924, vol. $2^{\circ}$ ano, p. 31). Estão relacionados também a uma série de comportamentos sociais e relacionais que visam criar um ambiente de bem-estar, assim como ilustrado pelo exemplo a seguir:

para termos uma vida saudável, é preciso alguns cuidados com nosso corpo e nossa mente. Veja alguns desses cuidados: cuidar da limpeza do corpo e do ambiente, dormir pelo menos oito horas por dia, levar uma vida tranquila e relacionar-se bem com as pessoas, praticar atividades físicas, como ginástica, esporte e dança, ler bons livros e ouvir boas músicas, comer alimentos frescos e saudáveis. (col. 611, vol. $2^{\circ}$ ano, p.163).

Essa prescrição de "boas atitudes" relacionadas à manutenção e promoção da saúde é também o objetivo central do tópico relacionado à "saúde mental" discutido anteriormente (col. 663, vol. $4^{\circ}$ ano).

Nesse conjunto de atitudes saudáveis estão também aquelas relacionadas à preservação do ambiente físico (cuidados com o ambiente), que também dizem respeito ao ambiente, entendido como espaço de convivência: “[a unidade tem por objetivo] conscientizar os alunos de cada um é responsável pelo cuidado com o ambiente coletivo e de que estar em um ambiente descuidado não é agradável e pode afetar a saúde.” (col. 674, vol. $2^{\circ}$ ano, p. 34).

Os objetivos relacionados ao autoconhecimento e a autopercepção dizem respeito àquelas unidades onde são apresentados os órgãos e as estruturas corporais, assim como as principais funções de cada uma delas. Esses objetivos aparecem em dois momentos bastante demarcados nesses quatro anos de escolaridade: quando da discussão acerca dos órgãos dos sentidos, característica do segundo ano, e na apresentação dos conteúdos relacionados à organização do corpo humano (órgãos e sistemas), conteúdo esse desenvolvido a partir do quarto ano e, especialmente, no quinto.

Vale ressaltar que uma preocupação frequente nas unidades que tratam dos órgãos dos sentidos é a preocupação com acidentes relacionados a eles, especialmente com a introdução de objetos ou práticas de higiene que possam causar algum tipo de ferimento: "uma das regras 
de higiene da orelha é evitar a introdução de quaisquer objetos ou líquidos no conduto auditivo" (col. 675, vol. $2^{\circ}$ ano, p.48, orientações para os professores). Vale lembrar que é nesse contexto que muitas coleções propõem atividades para detecção de possíveis deficiências de visão e audição, assim como discutem os seus possíveis encaminhamentos.

As unidades relacionadas à organização do corpo humano têm como característica o caráter descritivo dos conteúdos, cujo principal objetivo é a apresentação das estruturas de cada um dos sistemas e suas principais funções. Para isso, as coleções utilizam com muita frequência metáforas como "o caminho do alimento", o "caminho do sangue", "o caminho do ar" etc. Algumas coleções utilizam esse mote para apresentar, sob a marca do Tema Transversal Saúde, algumas tecnologias de diagnóstico e tratamento de doenças relacionadas a cada um dos sistemas, especialmente a hemodiálise, a doação e transfusão de sangue e órgãos e os exames diagnósticos por imagem.

O quarto conjunto de objetivos se relaciona às unidades que procuram criar condições para que os alunos consigam perceber as condições favoráveis e desfavoráveis à saúde, sob o ponto de vista dos determinantes coletivos de caráter amplo. São unidades que tratam o tema da saúde a partir de seus determinantes socioeconômicos, culturais e ambientais. Nestas, são discutidos aspectos relacionados às condições de moradia, aos costumes alimentares regionais, ao acesso à alimentação de qualidade e preços dos alimentos, às condições insalubres relacionadas a algumas ocupações (trabalho infantil, catadores de lixo) e, no tocante aos determinantes ambientais, às condições de acesso ao saneamento básico e água tratada e aos problemas decorrentes da poluição.

Três coleções apresentam unidades cujo objetivo central é discutir o que significa o termo saúde, a partir da perspectiva de bem-estar da OMS, assim como seus principais fatores intervenientes. Uma das coleções, no volume para o segundo ano, traz na unidade intitulada "Saúde" o seguinte questionamento: "O que é saúde? A palavra saúde aparece em muitos lugares e em muitas situações. Fica parecendo que saúde é o contrário de doença. Será que é só isso?" (coleção 679, vol. $2^{\circ}$ ano, p.86) e aponta como um dos objetivos dessa unidade "compreender a saúde em seu sentido mais amplo, aceito pela OMS, que se refere a ela como um estado de bem-estar físico, mental e social e não meramente como ausência de doença" (p.50, orientações para os professores). Outra coleção faz o mesmo questionamento e tem como "resposta esperada" para a questão "um completo bem estar físico, mental e social e não meramente a ausência de doença." (col. 611, vol. 2 2 ano, p.163). A coleção 886 traz a discussão acerca da definição de saúde na última unidade do volume do quinto ano, 
claramente no papel de síntese. Nela é proposta uma discussão semelhante, apontando ser a saúde relacionada ao bem estar se contrapondo à ideia de ausência de doença. Vale lembrar que nessa coleção há uma importante contradição entre essa definição, alinhada à OMS, e a abordagem adotada para o desenvolvimento das unidades anteriores, que tem como característica o contraponto e a dicotomia entre a saúde e a doença e o caráter prescritivo das orientações.

Pertencentes ao último conjunto aparecem as unidades que têm por objetivo fornecer orientações acerca de cuidados e medidas de prevenção voltadas a doenças ou agravos específicos. São relacionadas a uma série de temas tais como, prevenção de acidentes em casa, na rua e no trânsito; vacinação; cuidados com a radiação solar; doenças transmitidas por microrganismos, animais domésticos e animais peçonhentos; verminoses; saúde bucal, DST/Aids etc. Claramente, ao desenvolver os conteúdos relacionados à saúde, essas unidades adotam a perspectiva do risco ${ }^{36}$ ou da ameaça.

Essas unidades têm basicamente o mesmo modelo, que é caracterizado pela apresentação da doença (seus sintomas e agentes) ou do agravo, dos meios de transmissão (no caso das doenças infectocontagiosas) e da discussão acerca da importância da adoção das medidas de prevenção ou dos cuidados específicos. Alguns exemplos a seguir, dos muitos encontrados, ilustram esse conjunto de unidades: "para não ter cáries é muito importante uma alimentação saudável, sem consumo excessivo de doces. Além disso, é importante escovar os dentes após as refeições, passar fio dental e ir ao dentista regularmente.” (col. 793, vol. $5^{\circ}$ ano, p.107); "atenção, não brinque com fios elétricos, tomadas ou interruptores de sua casa e da escola. Não brinque também com fios elétricos da rua e nunca toque em fios desencapados" (col. 793, vol. $4^{\circ}$ ano, p.149); "que seres vivos vivem em nosso corpo e podem causar doenças? [...] entre eles [os 'moradores da pele'] estão o piolho, a sarna e os vermes [...]. Além de lavar as mãos, o que você pode fazer para evitar esses seres vivos?” (col. 674, vol. $2^{\circ}$ ano, p.30).

\footnotetext{
${ }^{36}$ Não são objeto nem pretensão do presente trabalho discutir o conceito de risco, que é objeto de estudo de diversos autores do campo da saúde que procuram conceituá-lo e defini-lo a partir do seu resgate histórico, sua utilização na epidemiologia e sua relação com diversas vertentes filosóficas. É possível afirmar, no entanto, que o conceito de risco está presente e é estruturante tanto no campo da epidemiologia "clássica", relacionado à prevenção de doenças, quanto no campo da promoção da saúde. (GUILAN, 1996; AYRES, 1997 e 2011; LUPTON, 1999; SPINK, 2001; CASTIEL, 2009, dentre outros).
} 
A tabela a seguir mostra a distribuição dos objetivos, segundo os conjuntos acima apresentados por cada uma das coleções analisadas (tabela 4).

\begin{tabular}{|c|c|c|c|c|c|c|c|c|}
\hline \multirow{2}{*}{$\begin{array}{l}\text { Código da } \\
\text { coleção }\end{array}$} & \multicolumn{2}{|c|}{$\begin{array}{c}\text { Aquisição ou } \\
\text { mudança de } \\
\text { hábitos }\end{array}$} & \multirow{2}{*}{$\begin{array}{l}\text { Compor- } \\
\text { tamentos } \\
\text { e atitudes }\end{array}$} & \multirow{2}{*}{$\begin{array}{l}\text { Medidas } \\
\text { de } \\
\text { prevenção }\end{array}$} & \multirow{2}{*}{$\begin{array}{c}\text { Autoconh } \\
\text { ecimento }\end{array}$} & \multirow{2}{*}{$\begin{array}{l}\text { Definição } \\
\text { de saúde }\end{array}$} & \multicolumn{2}{|c|}{$\begin{array}{l}\text { Reconhecer fatores } \\
\text { favoráveis e } \\
\text { desfavoráveis }\end{array}$} \\
\hline & Higiene & $\begin{array}{c}\text { Alimen- } \\
\text { tares }\end{array}$ & & & & & Sociais & $\begin{array}{c}\text { Ambien- } \\
\text { tais }\end{array}$ \\
\hline 611 & 4 & 4 & 7 & 15 & 10 & 2 & 2 & 4 \\
\hline 632 & 5 & 4 & 3 & 9 & 5 & 0 & 1 & 1 \\
\hline 651 & 4 & 3 & 4 & 9 & 6 & 0 & 1 & 2 \\
\hline 674 & 5 & 2 & 3 & 8 & 5 & 0 & 1 & 1 \\
\hline 663 & 1 & 1 & 2 & 10 & 6 & 0 & 2 & 2 \\
\hline 679 & 5 & 3 & 4 & 12 & 9 & 1 & 2 & 3 \\
\hline 675 & 4 & 3 & 1 & 6 & 9 & 0 & 4 & 2 \\
\hline 793 & 2 & 2 & 4 & 14 & 6 & 0 & 1 & 2 \\
\hline 886 & 5 & 3 & 3 & 15 & 7 & 1 & 3 & 3 \\
\hline 907 & 6 & 2 & 4 & 13 & 8 & 0 & 2 & 3 \\
\hline 924 & 6 & 3 & 5 & 13 & 7 & 0 & 1 & 1 \\
\hline Total & 47 & 30 & 40 & 124 & 78 & 4 & 20 & 24 \\
\hline
\end{tabular}

Tabela 4: distribuição dos objetivos segundo os conjuntos, por coleção.

A partir desse mapeamento, percebe-se claramente que o conjunto mais frequente diz respeito às unidades que têm por objetivo a apresentação de orientações voltadas a um conjunto de atitudes associadas a uma doença ou agravo específico, para minimizar ou eliminar, quando possível, o risco específico. Ou seja, pode-se dizer que, no tocante aos objetivos pedagógicos, as unidades que tratam do tema da saúde nos livros didáticos aqui analisados necessitam que se faça um contraponto com a doença ou agravo especifico, que devem ser compreendidos como ameaças ou desfechos que podem ser evitados ou minimizados em função da adoção ou não de determinadas atitudes e cuidados.

Tomando como referência os conjuntos acima citados, em termos percentuais para o geral das coleções, os objetivos têm a seguinte distribuição: "medidas de prevenção e cuidados específicos" 34\% (124), "aquisição e/ou mudança de hábitos" e "autoconhecimento" 21\% (77 e 78 respectivamente); "reconhecimento de fatores favoráveis e desfavoráveis de caráter coletivo" 12\% (44) e "definições de saúde” 1\% (4) (gráfico 9). 


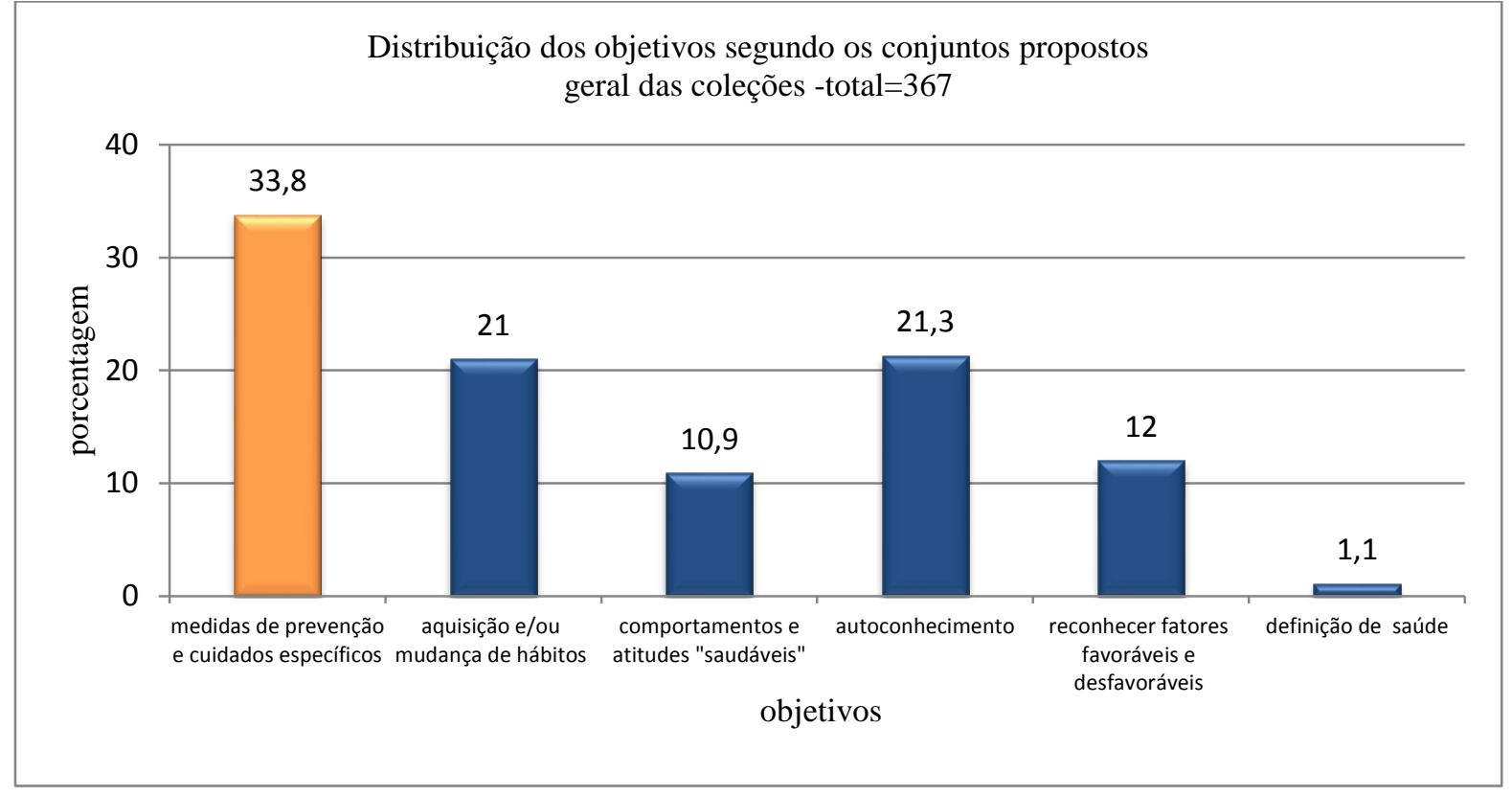

Gráfico 9: distribuição dos objetivos segundo os conjuntos propostos. Geral das coleções

Se partirmos do pressuposto de que os objetivos relacionados às medidas de prevenção, à aquisição e mudança de hábitos e à discussão acerca dos comportamentos e atitudes consideradas saudáveis buscam criar condições para que os alunos adotem certos comportamentos que, pelo menos em tese, irão contribuir para a manutenção ou melhoria de sua saúde, há novamente uma clara ênfase no indivíduo. A partir dessa análise, é possível, portanto, dizer que cerca de dois terços $(66 \%)$ dos objetivos dizem respeito apenas à dimensão individual da saúde.

Em outras palavras, ao definirem os objetivos relativos à saúde (sejam eles relacionados à higiene, a medidas de prevenção, à alimentação, a um conjunto de atitudes e comportamentos etc.) os livros didáticos têm como foco mudanças que, se forem efetivadas, deverão ocorrer no nível do indivíduo, no seu comportamento, nos seus hábitos, sendo ele responsável, a partir de suas escolhas, por essas mudanças.

Como afirmado anteriormente, esse nível de análise buscou compreender como a saúde é abordada no conjunto dos livros didáticos como um todo, Para tanto, as unidades selecionadas foram analisadas em função das concepções de saúde que embasam sua elaboração, dos determinantes do processo saúde-doença mais enfatizados e dos objetivos pedagógicos de cada uma delas. 
A despeito dos limites dessa análise e das importantes diferenças existentes entre as coleções é possível dizer que, no que tange aos aspectos analisados (concepções, determinantes e objetivos), o conjunto das coleções analisadas é bastante coerente.

$\mathrm{Na}$ medida em que a concepção de saúde predominante diz respeito àquela que entende a saúde como ausência de doença ou em contraponto a essa (mesmo que em suas apresentações muitas coleções explicitem concepções distintas), é profundamente coerente que os objetivos pedagógicos ligados à saúde digam respeito à adoção de comportamentos e medidas relacionados a doenças ou agravos específicos, a partir do ponto de vista da prevenção, tendo a ideia de risco como pano de fundo para essa mudança. Daí decorre o caráter prescritivo de muitos textos analisados e a grande predominância, em termos numéricos, de unidades que apresentam objetivos dessa natureza.

Além disso, se essas medidas de prevenção dizem respeito às mudanças que devem ocorrer no nível individual para que, a partir delas, o indivíduo possa melhorar sua situação de saúde, os determinantes comportamentais são aqueles que tendem a ser mais valorizados e enfatizados. Nesse caso, a ênfase está nas escolhas ou hábitos individuais, a partir de um risco determinado por uma doença ou agravo. A ênfase na aquisição ou mudança de hábitos ou, em alguns casos, na adoção de determinado "estilo de vida" vem ao encontro dessa perspectiva.

Por fim, se o foco do trabalho é a incorporação de comportamentos, é bastante coerente que os fatores que não estejam, pelo menos parcialmente, sob o controle do indivíduo (ou de suas famílias em se tratando das crianças que são os principais leitores desses livros) não sejam o principal objeto de aprendizagem. Assim, é esperado que os determinantes definidos aqui como de natureza coletiva, tais como os socioeconômicos, culturais e ambientais, apareçam pouco ou com pouco destaque no geral das unidades. Quando aparecem, são tratados a partir da mesma perspectiva dos demais e com a mesma importância atribuída aos hábitos, às escolhas, às medidas de caráter individual.

A questão que se coloca, portanto, não está relacionada à coerência, ou a falta dela, que conjunto dos livros analisados apresentam. Diz respeito a uma determinada visão hegemônica acerca da saúde, assim como sobre o papel atribuído aos fatores que influenciam e determinam a situação de saúde dos indivíduos e da população - sejam eles de caráter natural ou historicamente constituídos, ou relacionados às dimensões individual e coletiva do processo saúde-doença - e o quanto essa visão é capaz de propiciar reais condições para que os alunos possam posicionar-se criticamente frente aos contextos em que estão inseridos, a 
186

fim analisar (e enfrentar) os fatores que influenciam a sua própria condição de vida e de saúde, de sua família e das comunidades em que vivem. 


\section{CONSIDERAÇÕES FINAIS E IMPLICAÇÕES PARA O ENSINO DO TEMA DA SAÚDE}

Definimos como objetivo do trabalho aqui apresentado compreender como os temas relacionados à saúde humana vêm sendo desenvolvidos nos livros didáticos para os anos iniciais do Ensino Fundamental. Para tanto, optamos por analisar os livros aprovados no Programa Nacional do Livro Didático de 2010 (PNLD 2010), por entender ser essa amostra a mais significativa desse material, na medida em que são esses os livros que estão no cotidiano de trabalho de milhões de alunos e milhares de professores das redes públicas de educação do país.

Como questão de fundo, buscamos compreender quais são as concepções e entendimentos acerca da saúde que estão na base da elaboração das unidades que tratam do tema nesses livros, assim como o papel e a importância atribuída aos diversos fatores que influenciam o processo saúde-doença. Além disso, procuramos mapear os temas e os momentos em que aparecem nesses anos de escolaridade, a fim de traçar o percurso temático relacionado à saúde, proposto por este conjunto de livros, o que denominamos como o "currículo da saúde".

Primeiramente, é preciso destacar certa heterogeneidade encontrada entre as coleções no que tange às concepções de saúde, que acabam por conformar distintas abordagens ao tema, assim como definem a escolha e seleção dos objetivos a serem atingidos, dos conteúdos que serão desenvolvidos, das orientações para alunos e professores e das propostas de atividades a serem desenvolvidas.

Quando analisadas individualmente, foi possível perceber que um conjunto minoritário de coleções aborda a questão da saúde a partir de seu conceito ampliado, incorporando seus aspectos sociais, econômicos e culturais, a partir da ideia de direito à saúde. Apesar de grande parte das coleções em algum momento abordarem tais fatores, na maioria das vezes quando relacionados a temas ou assuntos específicos ou como exemplos esporádicos, esse conjunto de livros se distingue dos demais por assumir esses aspectos como fios condutores da proposta para o desenvolvimento do tema.

Nesse sentido, a discussão concernente a esses aspectos não aparece circunscrita a temas específicos, onde tradicionalmente são abordados (como por exemplo, relacionada ao 
Mal de Chagas, à questão da água tratada e do saneamento básico etc.), mas sim permeia os diversos assuntos e momentos onde são tratados os conteúdos relacionados à saúde.

Por outro lado, a maioria das coleções, a despeito de apontar nos seus textos de apresentação uma perspectiva bastante distinta, continua a abordar a saúde enfatizando seus aspectos biológicos, principalmente a partir de sua oposição à doença, e com forte ênfase no indivíduo. Nessas coleções, grande parte das unidades que se propõem a discutir o tema da saúde acaba por apresentar conteúdos relacionados à doença, tais como a descrição dos agentes etiológicos, sintomas, meios de transmissão, medidas de prevenção e/ou tratamento etc., ou ainda a descrição de processos fisiológicos e estruturas anatômicas.

Exemplo emblemático dessa abordagem é o tratamento dado ao tema da reprodução humana, onde grande parte das coleções descreve esse processo restringindo-se à descrição da fecundação apenas nos seus aspectos biológicos, como o "encontro de óvulo com o espermatozoide" ou apresenta a reprodução humana como semelhante à de "outros animais que têm fecundação interna". Mesmo considerando que essas informações estão correta e a importância de abordá-la, assim como as dificuldades inerentes ao desenvolvimento do tema da sexualidade humana sala de aula, é possível perceber que, a partir dessa perspectiva, desconsideram-se todos os demais aspectos relacionados à sexualidade humana, reduzindo-a apenas ao seu processo fisiológico.

Essa perspectiva é exatamente o cerne da crítica apresentada pelos PCN à tradição do ensino dos temas relacionados à saúde (denominada pelos documentos como "biologismo"):

As experiências mostram que transmitir informações a respeito do funcionamento do corpo e a descrição das doenças, bem como um elenco de hábitos de higiene, não é suficiente para que os alunos desenvolvam atitudes de vida saudável. (BRASIL, 1997c, p.61).

Nesse sentido, a despeito do avanço conceitual da área da saúde coletiva e da própria área de ensino de ciências que apontam para a necessidade de abordar o tema da saúde humana a partir de uma moldura mais ampla, que incorpore aspectos de diversas naturezas, a perspectiva de ensino que reduz a saúde a sua dimensão biológica continua a prevalecer nos livros didáticos. Assim, pode-se dizer que há um importante distanciamento entre o discurso presente nas apresentações das coleções, que se vincula à definição de bem-estar da OMS e aos PCN (no que tange às diretrizes para o ensino do tema) e o que é efetivamente desenvolvido no decorrer dos volumes. 
Cabe esclarecer que em nenhum momento tomamos as recomendações apresentadas pelos PCN como critérios de análise, avaliação, qualificação, adequação ou não dos livros didáticos. No entanto, as coleções analisadas invariavelmente adotam os Parâmetros como referências, muitas vezes de maneira explícita, na sua estruturação ou para o desenvolvimento das unidades. A utilização dos eixos temáticos propostos pelos PCN para o ensino de Ciências ou a menção aos temas transversais são indicadores claros dessa adoção. É pertinente dizer que a menção das recomendações aos Parâmetros como estruturantes da coleção continua a ser importante critério de escolha dos livros por parte dos professores, residindo aí uma possível explicação para a utilização dessas orientações pelas coleções.

Além disso, é essencial destacar que ao apontarmos para essa tendência em enfatizar os aspectos biológicos não estamos afirmando que tais aspectos têm menor importância no ensino dos temas relacionados à saúde. Ao contrário, entendemos que é fundamental que os alunos sejam capazes de compreender os diversos fatores que dizem respeito às situações de saúde, dentre esses aqueles relacionados à própria doença, aos mecanismos biológicos inerentes a esse processo, às medidas preventivas e de tratamento, além do reconhecimento e compreensão de suas estruturas anatômicas e seus processos fisiológicos. Mas parece-nos no mínimo insuficiente abordar o tema da esquistossomose ou da fecundação humana, por exemplo, sem que sejam relacionados às condições socioeconômicas e de moradia, no caso do primeiro, assim como a todas as questões culturais envolvidas com a sexualidade humana, no segundo. A questão que se coloca, portanto, não está relacionada à maior ou menor importância dada ao desenvolvimento de conteúdos relacionados aos aspectos biológicos, mas sim a redução das discussões sobre a saúde a apenas eles.

Pode-se dizer que a influência decisiva dos fatores sociais de caráter coletivo na situação de saúde dos indivíduos, grupos e populações - ou a determinação social do processo saúde-doença - é consenso na área da saúde (BARATA, 2005; BUSS e PELLEGRINI FILHO, 2007), baliza a produção teórica e conceitual da área da Saúde Coletiva há muito tempo, influencia política públicas deste de outros setores e perece ser bastante óbvia. Nesse sentido, parece-nos evidente que para um ensino que tenha como propósito criar reais condições para que os alunos sejam capazes de compreender os aspectos que influenciam sua saúde é premente que a discussão acerca de fatores seja entendida como básica e indispensável. Assim, é necessário que os livros didáticos apropriem-se de maneira consistente desses referenciais, a fim de elaborar propostas que incorporem esses fatores como pressupostos para a elaboração das unidades e não apenas os apresentem de maneira 
esporádica ou como exemplos, muitas vezes descontextualizados do restante da unidade ou sem relação com o cotidiano dos alunos.

A despeito das diferenças existentes entre as coleções, ao serem analisadas no conjunto, estas apresentaram alguns pontos comuns que devem ser destacados.

Quanto aos temas, apesar da grande variedade que foi possível mapear, alguns são comuns a todas as coleções e constituem a estrutura do que denominamos como "currículo da saúde" para os anos iniciais do Ensino Fundamental. Temas como os órgãos dos sentidos, sistemas do corpo humano, higiene pessoal (incluindo a saúde bucal), alimentação e nutrição e doenças relacionadas com a água são comuns a todas as coleções. Outros temas tais como os relativos aos problemas causados pela poluição atmosférica, às vacinas, à prevenção de acidentes em casa e no trânsito e às orientações sobre a importância da prática de atividades físicas, compõem um segundo conjunto bastante presente no geral das coleções.

Além disso, alguns assuntos são marcas distintivas de anos específicos como, por exemplo, os órgãos dos sentidos que caracterizam a proposta para o segundo ano, as doenças de veiculação hídrica para o terceiro e os sistemas do corpo humano, como marca curricular do quinto. É possível dizer, portanto, que há um conjunto de temas que constituem a estrutura de um currículo referente à saúde para esses anos de escolaridade. Nesse sentido, parece haver certa tradição na proposição desse percurso e que essa tradição é adotada pelos livros didáticos de maneira bastante uniforme para a proposição da sequência de conteúdos e para o encadeamento lógico dos temas.

Um segundo aspecto a ser apontado diz respeito às definições de saúde que as coleções apresentam como seu entendimento sobre o tema. Claramente, há no conjunto de livros analisados a preocupação afirmar a adoção da perspectiva do bem-estar biopsicossocial, assim como formulada pela OMS, como referência para a saúde. Mesmo que apresentem variações ligadas ao maior ou menor peso dado aos hábitos pessoais, aos estilos de vida ou aos outros fatores que interferem na situação de saúde das pessoas, os livros didáticos aprovados pelo PNLD 2010 apontam essa perspectiva como pressuposto principal. Nesse sentido, o discurso relacionado à saúde se alinha a uma perspectiva que, a despeito das críticas já apontadas, incorpora aspectos psicológicos e sociais, além dos biológicos na definição do próprio termo, o que é comumente definido como conceito ampliado de saúde.

No entanto, assim como já discutido, no desenvolvimento das unidades há a hegemonia de um pensamento que contradiz essa perspectiva, no qual a saúde é discutida a 
partir da doença e são apresentados conteúdos relativos à sua descrição, assim como orientações voltadas à prevenção específica, a partir de um risco ou ameaça. A perspectiva do bem-estar proposta pela OMS - que na própria definição aponta que a saúde não deve ser entendida "meramente como ausência de doença ou incapacidade" (OMS, 1946) -, geralmente aparece de maneira pontual e esporádica nos livros analisados, relacionada a temas específicos, tais como a prática de atividades físicas, aspectos relacionais e lazer. Nesse sentido, é possível dizer que há um importante distanciamento entre o discurso sobre a saúde apresentados nos livro didáticos e o que é efetivamente posto em prática no desenvolvimento das unidades.

Coerentemente com esse discurso relacionado ao bem-estar, nos momentos em que não estão relacionados diretamente com agravos específicos, os livros apresentam conteúdos e orientações que se aproximam à perspectiva da promoção da saúde. Nesses casos, fica evidente a preocupação com a aquisição de hábitos considerados saudáveis ou com questões ligadas a comportamentos e escolhas pessoais a partir da ideia de estilos de vida.

A esse respeito, Carvalho e colaboradores (2007) apontam como um aspecto positivo o fato de que, em países europeus, os livros didáticos para anos iniciais de escolaridade tendem a adotar o modelo denominado pelos autores como "promotor de saúde", tendência essa que vai sendo substituída pela adoção do modelo biomédico no decorrer dos anos de escolaridade. Esses autores, no entanto, não têm a preocupação em discutir que perspectiva relacionada à promoção da saúde é essa ou se promoção da saúde voltada exclusivamente ao indivíduo e suas escolhas (o que parece ser o caso dos livros europeus) é, de fato, um aspecto positivo. O próprio movimento da promoção da saúde e inclusive a OMS há muito já fez essa crítica, modificando a própria definição do termo, com a necessária incorporação de aspectos coletivos e do contexto social nessa definição (WHO, 1998).

Certamente, em uma realidade de diferenças sociais como a encontrada no Brasil, a ideia de escolhas pessoais ou estilos de vida parece-nos, para dizer o mínimo, inadequada ou ingênua, principalmente em se tratando de livros destinados à escola pública, onde se encontram muitos alunos que vivem em realidades em que essas escolhas são literalmente impossíveis de serem feitas.

Retomando os PCN, já em 1997 esses documentos alertam para a perspectiva de promoção de saúde a ser adotada na escola, que deve, para cumprir seus objetivos, abarcar tanto a dimensão individual, quanto coletiva: 
A promoção da saúde [...] está estreitamente vinculada à eficácia da sociedade em garantir a implantação de políticas públicas voltadas para a qualidade de vida e ao desenvolvimento da capacidade de analisar criticamente a realidade e promover a transformação positiva dos fatores determinantes da condição de saúde. (BRASIL, 1997c, p. 67, grifos nossos).

É possível dizer, mais uma vez, que é necessária a incorporação dessa crítica por parte dos livros, a fim desenvolver propostas que tenham como pressupostos o desenvolvimento de aprendizagens com vistas a criar condições de transformação (ou enfrentamento) das condições contextuais desfavoráveis à saúde que porventura os alunos e suas famílias possam estar expostos. Parece-nos claro que a adoção apenas da perspectiva dos estilos de vida como principal pressuposto não dá conta dessa tarefa.

$\mathrm{O}$ aspecto que apareceu com maior destaque na análise aqui apresentada refere-se à ideia de que a saúde é fortemente tratada a partir do indivíduo, sendo este o foco de atenção e o cerne da atuação. Essa perspectiva é claramente identificada na análise dos determinantes do processo saúde-doença que são mais enfatizados nos livros. Mais do que qualquer outro aspecto, nessas coleções a situação de saúde depende de um conjunto de comportamentos que deve ser incorporado pelos indivíduos a fim preservar, manter ou melhorar sua saúde. Em outras palavras, o que se enfatiza é que "ser saudável" (ou não ficar doente) depende fundamentalmente de comportamentos a serem seguidos. Seja por meio da ideia da aquisição ou modificação de hábitos, das orientações acerca de atitudes voltadas à prevenção de doenças ou agravos específicos ou a partir da perspectiva das escolhas pessoais e estilos de vida, é o comportamento individual, e fundamentalmente ele, que vai determinar a situação de saúde das pessoas.

Ao retomar o parecer do Conselho Federal de Educação de 1974 relacionado aos antigos Programas de Saúde, quando afirmava que

ainda que se possa focalizar a saúde como um estado de equilíbrio ecológico, e possa a educação ser encarada no seu contexto ecológico e ecológicosocial, é para o indivíduo e sua ação que ela deve-se dirigir prioritariamente. O objeto e os objetivos do ensino da saúde na escola devem centrar-se no indivíduo e é para esse que se dirigem o interesse e a vocação do educador (BRASIL 1974, p.65, grifos nossos),

assim como o trabalho de Alves (1987) que afirmava que à época

para os livros didáticos, a Saúde nunca está relacionada à questão social, às condições de vida, nem às de trabalho. Ao contrário, é sempre um caso individual, a ser obtida com base nos bons hábitos. (p.40, grifos nossos), 
ou ainda os trabalhos de Mohr (1995) e Delizoicov (1995) que afirmam que os livros didáticos priorizavam o indivíduo e a prescrição de comportamentos e hábitos saudáveis e a despeito do avanço conceitual do campo da Epidemiologia Social e da Saúde Coletiva e do consenso acerca da importância dos determinantes sociais na constituição da situação de saúde das pessoas e grupos, assim como da proposta dos PCN para o ensino da temática da saúde apontarem para um caminho bastante distinto, pode-se dizer que pouco mudou nos livros didáticos em relação a essa questão desde as diretrizes traçadas há quase 40 anos.

É pertinente ressaltar que entendemos que todas as questões concernentes aos comportamentos e atitudes voltados à prevenção de doenças ou agravos são fundamentais no ensino dos temas relacionados à saúde. Novamente, a questão aqui colocada é a redução da saúde a um conjunto de comportamentos individuais que devem ser seguidos, a partir de orientações (ou prescrições), sem que sejam levados em conta os aspectos estruturais e contextuais em que essas crianças estão inseridas. São muitos os exemplos apresentados neste trabalho em que essa característica é evidente.

Além disso, tendo o individuo como único foco desconsideram-se todos os aspectos relativos à dimensão coletiva da saúde, tais como o direito à saúde e ao acesso à assistência, as responsabilidades coletivas e institucionais, as condições de vida, o reconhecimento dos aspectos culturais, os determinantes macroeconômicos, as desigualdades sociais, dentre outros.

Sobre essa questão, outra característica marcante das coleções diz respeito a pouca ênfase na ideia de saúde como direito. Essa ideia, quando aparece, se relaciona claramente a dois temas bastante específicos: a relação entre saúde e saneamento básico e a questão da vacinação. Ou seja, o direito à saúde não é tomado como pressuposto básico das discussões e sim se relaciona a temas específicos bem demarcados.

No primeiro caso, como buscamos apontar, há uma inversão entre o que é o objetivo final e as estratégias para alcançá-lo. Parece-nos que, em função da localização dessa discussão nas coleções, sempre vinculada às unidades denominadas como "ambiente" (e seus fatores abióticos), assim como sua relação a objetivos voltados à discussão sobre a importância da preservação ambiental, a saúde é vista como uma consequência do direito ao saneamento e não o saneamento como uma estratégia que visa melhorar as condições de saúde e a qualidade de vida da população. O que é meio passa a ser visto como fim e viceversa. 
Quanto ao direito à vacinação, a preocupação com a verificação do calendário vacinal dos alunos e a ênfase dada à disponibilização gratuita de vacinas na rede pública de saúde para a melhoria das condições de saúde dos alunos, configura-se como objetivo bastante recorrente nas coleções e de inegável valor. A questão é que ao circunscrever a discussão acerca do direito à saúde ao direito à vacinação, corre-se o risco de se compreender esse direito apenas como relacionado ao acesso à assistência à saúde, que reafirmamos ser fundamental. Por outro lado, o direito á saúde não diz respeito apenas à assistência, mas está fundamentalmente relacionado às condições dignas de moradia, trabalho, renda, acesso à informação, dentre outros fatores que devem ser compreendidos como condições e pressupostos de cidadania e, portanto, de responsabilidade coletiva e passível de reivindicações. Circunscrever o direito à saúde ao direito à assistência empobrece e, em última análise, despolitiza as discussões acerca do tema e muito dificilmente criará condições para o desenvolvimento, por parte dos alunos, de uma postura crítica frente aos contextos sociais no que concerne à saúde.

Buscamos apontar, mais uma vez afirmando a diferença existente entre as coleções, que há uma visão hegemônica para o tratamento dos temas relacionados à saúde que tende a tratar o tema a partir de algumas características: 1) a oposição da saúde em relação a uma doença ou agravo específico; 2) enfatiza os aspectos biológicos da saúde (ou da doença) em detrimento aos determinantes sociais da saúde; 3) atribui pouco destaque a aspectos historicamente constituídos, tais como renda, condições de moradia, acesso aos bens e consumo, aspectos culturais etc.; 4) é pouco associada à ideia de direito, que aparece apenas relacionada a temas específicos (vacinação e saneamento, resguardadas as ressalvar feitas anteriormente) e 5) tem como foco principal o indivíduo e seu comportamento. Todos esses aspectos são bastante coerentes entre si e conformam uma determinada visão de saúde, assim como determinam a natureza dos objetivos pedagógicos relacionados ao tema bastante distintos (SCHALL e STRUCHINER, 1999). Tal visão e objetivos podem suscitar basicamente dois tipos de entendimento de como se estabelece o processo saúde-doença nos indivíduos e na população, assim como os fatores que o determinam.

Primeiramente, a saúde (e seu contraponto, a doença) pode ser compreendida como algo aleatório ou fortuito, que depende muito mais da sorte, ou falta dela, e da exposição do indivíduo aos agentes, em função de condições ambientais, num processo de naturalização desse processo, assim como de seus fatores. Entendido como um processo iminentemente, ou prioritariamente, natural, as orientações voltadas à preservação ou melhoria da saúde passam 
a ter seu foco na quebra da relação entre o agente causador, o hospedeiro (ou o indivíduo em que a ação do agente se manifesta) e as condições ambientais, ou seja, adota-se a tríade epidemiológica, em sua versão clássica, baseada na história natural da doença de Leavel e Clark. Nesse caso, as condições de vida, moradia, acesso aos bens e serviços etc. passam a ser compreendidas como mais um, dentre muitos, fatores que influenciam o processo saúdedoença. Não há, portanto, muito a ser feito, a não ser cercar-se dos meios e estratégias necessárias, dentro do contexto vivido, para garantir uma situação de saúde minimamente adequada.

Em segundo lugar, a saúde pode ser compreendida exclusivamente como resultante de comportamentos relacionados às escolhas e a medidas de prevenção ou proteção que dizem respeito exclusivamente ao indivíduo, o que levará muito provavelmente a um processo de responsabilização ou culpabilização do indivíduo por sua situação de saúde. Ou seja, cabe ao indivíduo, e apenas a ele, a partir de suas escolhas, “decidir” pela adoção de comportamentos e atitudes que o farão "mais saudável”, conformando-se com as condições contextuais ou estruturais em que está inserido e com os resultados dessas escolhas. Mesmo em contextos de igualdade de acesso aos bens materiais e às condições de vida minimamente dignas essa perspectiva é bastante questionável, na medida em que parte do pressuposto que as escolhas são sempre conscientes e racionais, e balizadas por informações. No caso brasileiro, dada a profunda desigualdade existente entre a população, tratar a saúde como basicamente um resultado de escolhas de caráter é delegar a responsabilidade em assumir muitas escolhas tidas como saudáveis a uma expressiva parcela da população na qual essas escolhas são impossíveis.

Por fim, há que se perguntar que ideias relacionadas à saúde, assim como que tipo de atuação pessoal e social esses livros podem propiciar aos alunos. Em outras palavras, quais são implicações para o ensino dos temas relacionados à saúde, assim como para compreensão dos aspectos relacionados ao processo saúde-doença que as abordagens propostas pelos livros didáticos analisados promovem?

Aqui é fundamental novamente destacar as diferenças existentes entre as coleções e a compreensão desse conjunto de livros não como um bloco homogêneo ou monolítico, mas sim permeado de importantes diferenças e perspectivas relacionadas à saúde. Como procuramos apontar na análise específica, as coleções abordam de maneira distinta os temas relacionados à saúde, assim como atribuem maior ou menor peso aos aspectos aqui discutidos. Nesse sentido, propiciam diferentes entendimentos acerca do tema e do papel que 
os diversos determinantes exercem no processo saúde-doença e propõem orientações e recomendações coerentes com a perspectiva adotada.

Também como já discutido, as coleções que adotam abordagens mais voltadas à compreensão da saúde a partir de seu conceito ampliado e trabalham de maneira efetiva os fatores de diversas naturezas relacionados à situação de saúde das pessoas e das populações podem ser consideradas exceções e se diferenciam bastante da regra geral.

Se a relação entre as condições sociais, culturais e econômicas em que os alunos estão inseridos e sua situação de saúde (assim como de suas famílias e comunidades) é pouco considerada como objeto de sua aprendizagem e se a saúde é compreendida hegemonicamente como resultante da adoção de um conjunto de comportamentos, atitudes e escolhas de caráter iminentemente individual, caberá aos alunos somente incorporar esses comportamentos a fim de preservar (ou não piorar) sua saúde. O que se espera, portanto, é que os alunos "aprendam a escolher", dentro do contexto em que estão inseridos, os "melhores" ou "mais saudáveis" comportamentos a fim de garantir sua saúde. Ou ainda, espera-se que os alunos passem a obedecer tais recomendações, ou prescrições, a fim de preservar sua saúde, sob o risco de comprometê-la.

Retomando Buss (2000), a partir dessa perspectiva, todos e quaisquer aspectos que não estão, pelo menos parcialmente, ao alcance das decisões individuais não são considerados objeto de discussão e, no caso da escola, de aprendizagem. Nesse sentido, as discussões acerca das condições desfavoráveis à saúde em que os alunos possam estar inseridos não fazem parte, portanto, do rol de situações de aprendizagens que estes estarão expostos a partir das propostas dos livros didáticos. Uma consequência clara dessa característica é que qualquer tipo de mecanismo de reinvindicação coletiva acerca da melhoria dessas condições, assim como de garantia do direito à saúde não se configuram como objeto de aprendizagem escolar.

Entendida a escola como local e a educação como prática social que, pelo menos em tese, se propõem a criar condições para que os alunos sejam capazes de posicionar-se criticamente frente à realidade, a partir da compreensão de seus mais distintos aspectos, inclusive os que dizem respeito à saúde, estes devem ser objeto de aprendizagem dos alunos. Nesse sentido, é fundamental que o livro didático, compreendido como importante instrumento para professores e alunos no desenvolvimento curricular, incorpore de maneira efetiva os referenciais originários do campo da saúde, especialmente a relação entre as condições historicamente constituídas e as situações de saúde dos indivíduos e da população, a fim oferecer aos alunos e professores condições para esse posicionamento crítico. 
Em ouras palavras, é apenas por meio da compreensão de que esses fatores não são naturais e nem tampouco obra do acaso que a escola propiciará condições para que os alunos e professores os compreendam como passíveis de modificação e transformação, ou seja, “visualizar um mundo que 'ainda' não está em ordem, para ampliar as possibilidades de melhoria das condições de vida." (GIROUX e SIMON, 2002, p.99).

Somente com a incorporação efetiva e substancial desses conceitos, que não podem ser apresentados apenas como ilustrações, exemplos ou fatos descontextualizados, mas sim tomados como pressupostos básicos para o desenvolvimento do tema da saúde, é que os livros didáticos brasileiros, a partir do conjunto de discussões por eles proposto, poderão ser instrumentos importantes para o desenvolvimento de aprendizagens que possam vir a contribuir para a diminuição das iniquidades em saúde relacionadas às desigualdades de diversas ordens existentes no país, com vistas à melhoria das condições de vida dos indivíduos, grupos e comunidades. 


\section{REFERÊNCIAS BIBLIOGRÁFICAS}

ALMEIDA FILHO, N. Bases históricas da Epidemiologia. Cadernos de Saúde Pública, Rio de Janeiro, v. 2, n. 3, p. 304-311, 1986.

Uma breve história da epidemiologia. In: ROUQUARYOL, M. Z. e ALMEIDA

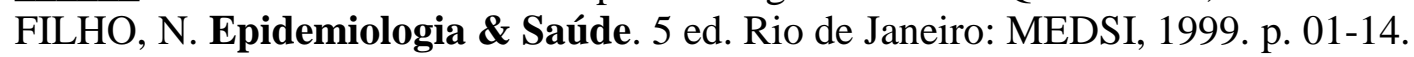

. O conceito de saúde: o ponto-cego da epidemiologia?. Revista Brasileira de Epidemiologia, São Paulo, v. 3 n 1-3, p. 04-20, 2000a.

. A Ciência da Saúde. São Paulo, HUCITEC, 2000 b.

. Qual o sentido do termo saúde? Cadernos de Saúde Pública, Rio de Janeiro, v.16, p.300-01, 2000c.

. For a General Theory of Health: preliminary epistemological and anthropological notes. Cadernos de Saúde Pública Rio de Janeiro, v.17, 2001, p.753-70.

$160 \mathrm{p}$.

O que é saúde? Rio de Janeiro: Ed. FIOCRUZ, 2011. (Coleção Temas em Saúde).

ALVES, N. G. A saúde na sala de aula: uma análise nos livros didáticos. Cadernos CEDES, n.18. São Paulo: Cortez, 1987, p. 38-53.

AROUCA, A. S. S. O Dilema Preventivista: contribuição para a compreensão e crítica da medicina preventiva. São Paulo: Editora UNESP; Rio de Janeiro: Editora FIOCRUZ, 2003.

AYRES, J.R.C.M. Sobre o risco: para compreender a epidemiologia. São Paulo: HUCITEC, 1997.

. Uma concepção hermenêutica de saúde. PHISYS: Revista de Saúde Coletiva, Rio de Janeiro. v.17, n.1, p. 43-62, 2007.

. Desenvolvimento histórico-epistemológico da Epidemiologia e do conceito de risco.

Cadernos de Saúde Pública, São Paulo, v. 27, n.7, p.1301-11, 2011.

AYRES, J. R. C. M.; CALAZANS, G. J.; SALETTI FILHO, H. J.; FRANÇA-JUNIOR. Risco, vulnerabilidade e práticas de prevenção e promoção da saúde. In: CAMPOS, G. W. S. et. al. (orgs.). Tratado de Saúde Coletiva. São Paulo: HUCITEC; Rio de Janeiro: Ed. FIOCRUZ, 2006. p. 375-417.

BAGnAto, M. H. S. O ensino da saúde nas escolas de $1^{\circ}$ grau. Pró-posições, Campinas, vol. 1 (1), p. 53-59, 1990.

BARATA, R. B. Epidemiologia Social. Revista Brasileira de Epidemiologia, São Paulo, vol. 8, n.1, p 07-17, 2005.

. Desigualdades Sociais e Saúde. In: CAMPOS, G. W. S. et. al. (orgs.). Tratado de

Saúde Coletiva. São Paulo: HUCITEC; Rio de Janeiro: Ed. FIOCRUZ, 2006. p. 457-86. 
BARDIN, L. Análise de conteúdo. $4^{\mathrm{a}}$ Ed. revista e atualizada. Lisboa: Edições 70 Ltda. 2009.

BARRETO, M. L. Epidemiologia, sua história e crises: notas para pensar o futuro. In: COSTA, D. C. (org.). Epidemiologia: Teoria e Método. São Paulo: HUCITEC-ABRASCO, 1990. p. 19-38.

BARROS, J. A. Pensando o processo saúde-doença: a que responde o modelo biomédico? Saúde e Sociedade, São Paulo, vol.11, n. 1, p 67-84, 2002.

BIZZO, N. Falhas no ensino de ciências. Ciência Hoje, vol. 159, n. 27, p.26-31, Abril, 2000.

BRAGA, S. M. A.; MORTIMER, E. F. Os gêneros de discurso do texto de Biologia dos livros didáticos de ciências. Revista Brasileira de Pesquisa em Educação em Ciências, v.3, n.3, p.56-74, set.-dez. 2003.

BRASIL. Lei 5.692, de 11 de agosto de 1971. Fixa as Diretrizes e Bases para o ensino de $\mathbf{1}^{\circ}$ e $\mathbf{2}^{\mathbf{0}}$ graus, e dá outras providências. http://www.planalto.gov.br/ccivil_03/Leis/L5692.htm Acesso: 27 de abril de 2011.

Conselho Federal de Educação (CFE). Parecer 2.246/74. Ensino de $1^{\circ}$ e $2^{\circ}$ graus. Educação da Saúde e Programas de Saúde. Documenta 165. Brasília, 1974.

.Constituição (1988). Constituição da República Federativa do Brasil. Brasília, DF: Senado, 1988.

Lei 8.080 de 19 de setembro de 1990. Lei Orgânica da Saúde. 1990. Disponível em: www.planalto.gov.br/ccivil_03/Leis/L8080.htm. Acesso em: 10 fev. 2010. 1993. 120p.

Ministério da Educação. Plano decenal de educação para todos. Brasília: MEC,

Ministério da Educação. Secretaria de Educação Fundamental. Parâmetros Curriculares Nacionais: ciências naturais (1 $\mathbf{1}^{\mathbf{a}}$ a $\mathbf{4}^{\mathrm{a}}$ séries). Brasília: MEC/SEF. 1997a. 136p.

. Ministério da Educação. Secretaria de Educação Fundamental. Parâmetros Curriculares Nacionais: apresentação dos temas transversais, ética. Brasília: MEC/SEF. 1997b. 146p.

Ministério da Educação. Secretaria de Educação Fundamental. Parâmetros Curriculares Nacionais: meio ambiente, saúde (1 a $4^{\text {a }}$ séries). Brasília: MEC/SEF, 1997c. 128p.

Ministério da Educação. Secretaria de Educação Fundamental. Parâmetros Curriculares Nacionais: educação física. Brasília: MEC/SEF, 1997d. 96p.

Conselho Nacional de Educação (CNE). Câmara de Educação Básica. Resolução CEB No 2/1998. Institui as Diretrizes Curriculares Nacionais para o Ensino Fundamental. Brasília: Ministério da Educação e do Desporto. 1998a. Disponível em: http://portal.mec.gov.br/cne/arquivos/pdf/rceb02_98.pdf. Acesso: 27 de maio de 2011. 
Conselho Nacional de Educação (CNE). Câmara de Educação Básica (CEB). Parecer CEB 04/98. Diretrizes Curriculares Nacionais para o Ensino Fundamental. Brasília: Ministério da Educação e do Desporto. 1998b.

Ministério da Saúde. Secretaria de Políticas de Saúde. Projeto Promoção da Saúde. As cartas da Promoção da Saúde. Brasília: Ministério da Saúde, 2002.

Ministério da Saúde. Secretaria de Vigilância em Saúde. Secretaria de Atenção à Saúde. Política nacional de promoção da saúde. Brasília: Ministério da Saúde, $2006 a .60$ p. - (Série B. Textos Básicos de Saúde)

- Secretaria de Educação Básica. Guia do livro didático 2007: apresentação: séries/anos iniciais do ensino fundamental. Brasília: Ministério da Educação, Secretaria de Educação Básica, 2006b. 44 p

. Presidência da República. Casa Civil. Subchefia para Assuntos Jurídicos. Decreto no 6.286, de 5 de dezembro de 2007. Institui o Programa Saúde na Escola - PSE, e dá outras providências. Disponível em: http://www.planalto.gov.br/ccivil_03/_ato20072010/2007/decreto/d6286.htm. Acesso: 28 de abril de 2011.

Ministério da Saúde. Comissão Nacional Sobre Determinantes Sociais da Saúde. As Causas Sociais das Iniquidades em Saúde no Brasil. Relatório Final. 2008. Disponível em: $\quad$ http://determinantes.saude.homolog.bvs.br/lildbi/docsonline/6/1/016-Relatorio.pdf. Acesso: 10 abr. 2010.

Secretaria de Educação Básica. Guia do livro didático 2010: apresentação. Brasília: Ministério da Educação, Secretaria de Educação Básica, 2009. 52 p.

Conselho Nacional de Educação (CNE). Câmara de Educação Básica (CEB). Resolução no 7/2010. Fixa Diretrizes Curriculares Nacionais para o Ensino Fundamental de 9 (nove) anos. Brasília: Ministério da Educação. 2010a.

.Conselho Nacional de Educação (CNE). Câmara de Educação Básica (CEB). Parecer $n^{0}$ 11/2010. Diretrizes Curriculares Nacionais para o Ensino Fundamental de 9 (nove) anos. Brasília: Ministério da Educação. 2010b.

. Presidência da República. Casa Civil. Subchefia para Assuntos Jurídicos. Decreto no 7.084, de 27 de Janeiro de 2010. Dispõe sobre os programas de material didático e dá outras providências. Brasília. 2010c.

. Ministério da Educação. Secretaria da Educação Básica. Guia de livros didáticos: PNLD 2011: Apresentação. Brasília: Ministério da Educação, Secretaria de Educação Básica, 2010d.76 p.

Fundo Nacional de Desenvolvimento da Educação (FNDE). Resumo quantitativo PNLD - 1995 a 2010. 2010e. Disponível em: http://www.fnde.gov.br/index.php/pnld-dadosestatisticos. Acesso: 26 de maio de 2010 
Ministério da Educação. Fundação Nacional de Desenvolvimento da Educação (FNDE). O PNLD. 2011. Disponível em: http://www.fnde.gov.br/index.php/programas-livrodidatico Acesso: 31 de maio de 2011.

Ministério da Educação. Fundação Nacional de Desenvolvimento da Educação

(FNDE). Programas - Livros Didáticos. Disponível em: http://www.fnde.gov.br/index.php/pnld-dados-estatisticos. Acesso: 07 de fevereiro de 2012.

BREILH J. Epidemiologia: economia, medicina y política. México: Fontamara, 1989.

BREILH, J. \& GRANDA, E. Os novos rumos da epidemiologia, pp. 241-253. In Nunes, E (org.). As ciências sociais em saúde na América Latina. OPAS, Brasília. (Tendências e Perspectivas), 1985.

BUSS, P. M. Promoção da saúde e qualidade de vida. Ciência e Saúde coletiva, Rio de Janeiro, vol. 5, n.1, p.163-177, 2000.

. Uma introdução ao conceito de promoção da saúde. In: CZERESNIA, D. e FREITAS, C. M. Promoção da Saúde: debates, reflexões, tendências. 2 ed. ver. e ampl. Rio de Janeiro: Editora FIOCRUZ, 2009, p.19-42.

BUSS, P. M. e PELLEGRINI FILHO, A. A saúde e seus determinantes sociais. PHYSIS: Rev. Saúde Coletiva, São Paulo, vol.17, n.1, p.77-93, 2007.

CALlAHAN, D. The WHO definition of health. Stud Hasting Center, v 1, n3. 1973.

CÂMARA BRASILEIRA DO LIVRO. Pesquisa FIPE Produção e Vendas do Setor Editorial Brasileiro, 2009. São Paulo: Sindicato Nacional de Editores de Livros. 2010. Disponível em:http://www.snel.org.br/files/pesquisaMercado/relatorioAnual/relatorio_anual_2009.pdf Acesso: 25 de maios de 2011.

CAMARGO JÚNIOR, K. R. A biomedicina. PHYSIS: Revista de Saúde Coletiva. Rio de Janeiro, vol. 17, n.1, 2005.

CANGuilheM, G. O normal e o patológico. Trad. Maria Thereza Reding de Carvalho Barrocas - 6 edição revisada. Rio de Janeiro: Forense Universitária, 2009.

CAPONI, S. Georges Canguilhem y el estatuto epistemológico del concepto de salud. História, Ciências, Saúde - Manguinhos, Rio de Janeiro, vol. IV, n 2, p.287-307, 1997.

CARLINI-COTRIM, B. e ROSEMBERG, F. Os livros didáticos e o ensino para a saúde: o caso das drogas psicotrópicas. Rev. Saúde Pública, São Paulo, vol. 25, n.4, p.299-305,1991.

CARNEIRO, M.; dos SANTOS, W., MOL, G. Livro didático inovador e professores: uma tensão a ser vencida. Ensaio Pesquisa em Educação em Ciências, vol.7, n2. 2005.

CARVAlHO, G. \& CLÉMENT, P. \& BOGNER, F. Biology, Health and Environmental Education for better Citizenship (Biohead-Citizen). Bruxelles: Projet de recherche, FP6, Priority 7, 2004. 
CARVALHO, G.S. DANTAS, C., RAUMA, A.-L., LUZI, D., RUGGIER, R., GEIER, C., CAUSSIDIER, C., BERGER, \& CLÉMENT, P. Health Education approaches in school textbooks of 16 countries Biomedical model versus Health promotion. In: Proceedings of IOSTE international meeting on Critical Analysis of School Science Textbooks. Hammamet (Tunisia), 7 - 10 February 2007.

CASSAB, M e MARTINS, I. Significações de professores de ciências a respeito do livro didático. Ensaio Pesquisa em Educação em Ciências. vol.10, n. 1, p.97-116, jun. 2008.

CASSIANO, C. C. F. O mercado do livro didático no Brasil: da criação do Programa Nacional do Livro Didático à entrada do capital internacional espanhol (1985-2007). Tese (doutorado em Educação, História, Política e Sociedade). Pontifícia Universidade Católica de São Paulo (PCU-SP). 2007. f. 252.

CASTIEL, L. D. A saúde persecutória: os limites da responsabilidade. Rio de Janeiro: Ed. FIOCRUZ, 2007. 136 p.

Dédalo e os dédalos: identidade cultural, subjetividade e risco à saúde. In: CZERESNIA, D. e FREITAS, C. M. Promoção da Saúde: debates, reflexões, tendências. 2 ed. ver. e ampl. Rio de Janeiro: Editora FIOCRUZ, 2009, p.83-100.

CENTRO BRASILEIRO DE ESTUDOS DE SAÚdE (CEBES). Saúde em Debate, São Paulo v. 33, n. 83, p.341-42, 2009. [Editorial].

CHEVALLARD, Y. La Transposición Didácta: Del saber sabido al saber enseñado. 1 ed. Buenos Aires: Aique. 1991. 196 p.

CHOPIN, A. História dos livros e das edições didáticas. Educação e Pesquisa, São Paulo, vol.30, n.3, p. 549-566, set./dez. 2004.

COELHO, M. T. A. e ALMEIDA FILHO, N. Normal-patológico, saúde-doença: revisitando Canguilhem. PHYSIS: Rev. Saúde Coletiva, Rio de Janeiro, vol. 9, n.1, p. 13-36, 1999.

Conceitos de saúde em discursos contemporâneos de referência científica. História, Ciências, Saúde - Manguinhos, Rio de Janeiro, vol. 9, n 2, p.315-33, maio-agosto 2002.

COLlARES, C. A. L. e MOYSÉS, M. A. A. Educação ou Saúde? Educação X Saúde? Educação e Saúde!. Cadernos CEDES. nº15, São Paulo: Cortez, p.07-16, 1985.

CZERESNIA, D. Do contágio à transmissão: ciência e cultura na gênese do conhecimento epidemiológico. Rio de Janeiro: Ed. Fiocruz, 1997.

. Epidemiologia, Ciências Humanas e Socais e a integração das ciências. Revista de Saúde Pública, São Paulo, vol.42, n. 8, p.1112-17, 2008.

O conceito de saúde e a diferença entre prevenção e promoção. In: CZERESNIA, D. e FREITAS, C. M. Promoção da Saúde: debates, reflexões, tendências. 2 ed. ver. e ampl. Rio de Janeiro: Editora FIOCRUZ, 2009, p. 43-58. 
CZERESNIA, D. e FREITAS, C. M. Promoção da Saúde: debates, reflexões, tendências. 2 ed. ver. e ampl. Rio de Janeiro: Editora FIOCRUZ, 2009.

DAHLGREN, G. \& WHITEHEAD, M. Policies and Strategies to Promote Social Equity in Health. Stockhlm: Intitute for Future Studies; 1991.

DEJOURS, C. Por um novo conceito de saúde. Revista Brasileira de Saúde Ocupacional, São Paulo, vol.54, n.14, p. 07-11, 1986.

DELIZOICOV, N. C. O professor de ciências naturais e o livro didático (no ensino de programas de saúde). Dissertação (Mestrado em Educação)-Universidade Federal de Santa Catarina (UFSC). Florianópolis, 1995. 145 f.

DONNANGELO, M.C.F. Saúde e Sociedade. São Paulo: Pioneira, 1975.

FERLA, L. Feios, sujos e malvados sob medida: a utopia médica do biodeterminismo. São Paulo: Alameda, 2009.

FERNANDEZ, P. M. e SILVA, D. O. Descrição das noções conceituais sobre os grupos alimentares por professores de $1^{\mathrm{a}}$ a $4^{\mathrm{a}}$ série: a necessidade de atualização dos conceitos. Ciência e Educação, vol.14, n. 3, p.451-66, 2008.

FERREIRA, F. Noções da vida prática: livro de leitura para as escolas e de conhecimentos uteis para o povo. 9a ed. Rio de Janeiro: Alves \& C. 1894.

FLEXNER, A. Medical Education on United States and Canada. A report to the Carnegie Foundation for Advancement of Teaching. New York city: Carnegie Foundation for Advancement of Teaching, 1910. Disponível em: http://www.carnegiefoundation.org/sites/default/files/elibrary/Carnegie_Flexner_Report.pdf. Acesso: 11 de novembro de 2011.

FORQUIN, J. Escola e Cultura: as bases sociais e epistemológicas do conhecimento escolar. Trad. G. Louro. Porto Alegre: Artes Médicas, 1993.

FOUCAULT. M. Microfísica do poder. $18^{\mathrm{a}}$ ed. Organização e tradução de Roberto Machado. Rio de Janeiro: Edições Graal, 1979.

FRANÇA, V. H.; MARGONARI, C.; SCHALL, V. T. Análise do conteúdo das leishmanioses em livros didáticos de ciências e biologia indicados pelo programa nacional de livros didáticos (2008/2009). Ciência e Educação (UNESP. Impresso), v. 17, p. 679-694, 2011.

FREITAG, B.; COSTA, W. F. e MOTTA, R. O livro didático em questão. São Paulo: Cortez, 1997.

FREITAS, C. M. A vigilância da saúde para a promoção da saúde. In: CZERESNIA, D. e FREITAS, C. M. Promoção da Saúde: debates, reflexões, tendências. 2 ed. ver. e ampl. Rio de Janeiro: Editora FIOCRUZ, 2009a, p. 145-64.

FREITAS, E. O e MARTINS, I. Concepções de saúde no livro didático de ciências. Ensaio Pesquisa em Educação, vol.10, n.2. 2009. 
GARRAFA, V. e CORDÓN, J. Determinantes sociais da doença. Saúde em Debate, São Paulo, v. 33, n. 83, p.388-96. set./dez. 2009.

GIROUX, H. A. e SIMON, R. Cultura popular e pedagogia crítica: a vida cotidiana como base para o conhecimento curricular. In: MOREIRA, A. F. B e SILVA, T. T. (orgs.) Currículo, Cultura e Sociedade. $7^{a}$ ed. Tradução de Maria Aparecida Baptista. São Paulo: Cortez, 2002. p. 93-124.

GRUNDY, S. Curriculum: Product or Praxis. Londres: The Falmer Press, 1987.

GUILAN, M. C. R. O conceito de risco e sua utilização pela Epidemiologia, Engenharia e Ciências Sociais. $1996 . \quad$ Disponível em: http://www4.ensp.fiocruz.br/projetos/esterisco/maryfim1.htm. Acesso: 15 de setembro de 2011.

GUTTIERREZ, M. L. et al. La promociòn di salud. In: ARROYO, H.V. e CERQUEIRA, M. T. (orgs.) La promociòn de la salud y la educaciòn para la salud en América Latina. San Juan: Editora de La Universidade de Porto Rico, 1997, p. 121-143.

HIATT, M. D. Around the continent in 180 days: the controversial journey of Abraham Flexner. New York: Pharo, p.18-24, Winter 1999.

HÖFLING, E. M. Notas para discussão quanto à implementação de programas de governo: Em foco o Programa Nacional do Livro Didático. Educação \& Sociedade. Ano XXI, n 70, p. $159-170$, abril 2000.

KAPLAN, G. A. What's wrong with social epidemiology, and how can we make it better? Epidemiologic Review. vol. 26, p.124-35, 2004

KEMP, A. e EDLER, F. C. A reforma médica no Brasil e nos Estados Unidos: uma comparação entre duas retóricas. História, Ciências, Saúde - Manguinhos, Rio de Janeiro, vol. 11, n.3, p. 596-85, 2004.

KOIFMAN, L. O modelo biomédico e a reformulação do currículo médico da Universidade Federal Fluminense. História, Ciências, Saúde - Manguinhos, Rio de Janeiro, vol. VIII n. 1, p. 49-70, 2001.

KRIEGER, N. A glossary of social epidemiology. Epidemiology and Community Health, vol.55, p. 693-700, 2001.

LAJOLO, M. Livro Didático: um (quase) manual de usuário. Em aberto. Brasília, ano 16, n.69, p.03-09, jan./mar. 1996. Disponível em: http://rbep.inep.gov.br/index.php/emaberto/article/viewFile/1033/935. Acesso: 18 de maio de 2011.

LALONDE, M. El concepto del "campo de la salud": una perspective canadiense. In: Organización Panamericana de la Salud (OPS). Promoción de La Salud: una antologia. Washington, D.C.: OPAS, 1996 (Publicación Científica, 557). p 03-06 
LANGHI, R e NARDI, R. Ensino de astronomia: erros conceituais mais comuns presentes em livros didáticos de ciências. Cad. Bras. Ens. Fís., vol. 24, n.1, p.87-111, abr. 2007.

LAURELL, A.C. Para el estudio de la salud en su relación con el proceso de producción, pp. 61-94. In: ALAMES. Anales Taller Latinoamericano de Medicina Social. Medellín, 1987.

LIMA, G. Z. Saúde Escolar - perspectivas de desenvolvimento. Cadernos CEDES, nº15, São Paulo: Cortez, p. 55-61, 1985.

LIMA, M. e SILVA, P. Critérios que professores de química apontam como orientadores da escolha do livro didático. Ensaio Pesquisa em Educação em Ciências, vol.12, n.2, p.121$136,2010$.

LUPTON, D. Risk. New York: Routledge, 1999

LUZ. M. T. Saúde e instituições médicas no Brasil. Rio de Janeiro: Graal, 1986.

MACEDO, E. A imagem da ciência: folheando um livro didático. Educação e Sociedade, vol. 25, n. 86, p.103-129, abril 2004.

MANTOVANI, K. P. O Programa Nacional do Livro Didático - PNLD: impactos na qualidade do ensino público. Dissertação (mestrado em geografia humana). Faculdade de Filosofias, Letras e Ciências Humanas da Universidade de São Paulo. 2009. f.126.

MILANO, M. Sciencias physicas e naturaes, hygiene: de accôrdo com o programma official. $1^{\text {a }}$ ed. São Paulo: Monteiro Lobato, 1922.

MOHR. A. A saúde na escola: análise de livros didáticos de $\mathbf{1}^{\mathrm{a}}$ a $\mathbf{4}^{\mathrm{a}}$ séries. Dissertação (mestrado em educação). Fundação Getúlio Vargas. Instituto de Estudos Avançados em Educação. Rio de Janeiro, 1994, f. 70.

A saúde na escola: análise de livros didáticos de $1^{\mathrm{a}}$ a $4^{\mathrm{a}}$ séries. Cadernos de Pesquisa, São Paulo, n.94, p.50-57, 1995.

Análise do conteúdo de 'saúde' em livros didáticos. Ciência \& Educação, vol. 6, n.2, p.89-106, 2000.

A natureza da Educação em Saúde no Ensino Fundamental e os professores de Ciências. Tese (doutorado). Centro de Ciências da Educação, Universidade Federal de Santa Catarina. 2002. $410 \mathrm{f}$.

MOHR, A. e SCHALL, V. Rumos da Educação em Saúde no Brasil e sua relação com a Educação Ambiental. Cad. Saúde Pública, Rio de Janeiro, vol. 8, nº 2. abr/jun,1992. p. 199203.

MONTEIRO, P. H. N.; BIZZO, N. e GOUW, A. M. S. As Doenças Sexualmente Transmissíveis (DST) e a Aids nos livros didáticos para o Ensino Fundamental no Brasil: abordagens e implicações educacionais. Acta Scientiae, vol. 12, n. 1, p.123-138, 2010. 
MOREIRA, M. C. A; LIMA, A. e MARTINS, I. A saúde no livro didático de ciências: um exercício de análise. Anais do XV ENDIPE - Encontro Nacional de Didática e Prática de Ensino. Belo Horizonte. 2010.

MOURA, E. C. Ensino da saúde no currículo - subtema nutrição. Ciências e Cultura, vol. 42, p.283-287, 1980.

NAVARRO, V. What we mean by social determinants of health. International Journal of Health Services. vol. 39, n.3, p.423-41, 2009.

NOGUEIRA, R. P. Determinantes, determinação e determinismo sociais. Saúde em Debate. São Paulo, vol. 33, n. 83, p.397-406, set./dez. 2009.

NOMOTO, M; NONAKA, D; MIZOUE, T; KOBAYASHI, J; JIMBA, M. Content analysis of school textbooks on health topics: a systematic review. BioScience Trends. vol. $5, \mathrm{n}^{\circ} 2$, p.61-68, 2011.

NUNES, E. D. Saúde Coletiva: história e paradigmas. Interface - Comunicação, Saúde, Educação. Botucatu- SP, v. 2, n. 3, p.107-116, Agosto 1998.

Saúde Coletiva: uma história recente de um passado remoto. In: CAMPOS, G. W. S. et. al. (orgs.). Tratado de Saúde Coletiva. São Paulo: HUCITEC; Rio de Janeiro: Ed. FIOCRUZ, 2006, p.19-40.

NUTBEAN, D. Health promotion glossary. Health Promotion International. vol.13, n.4, p. 349-64, 1998.

OLIVEIRA M. A. C e EGRY E. Y. A historicidade das teorias interpretativas do processo saúde-doença. Revista da Escola de Enfermagem da USP. São Paulo, vol. 34, n. 1, p.09-15, 2000.

PAGLIOSA, F. L e DA ROS M. A. O Relatório Flexner: para o bem e para o mal. Revista Brasileira de Educação Médica. Rio de Janeiro, vol. 32 n.4, p.492-99, 2008.

PINHÃO, F. L e MARTINS, I. A relação Saúde-ambiente no livro didático de ciências: uma análise preliminar. Anais do XV ENDIPE - Encontro Nacional de Didática e Prática de Ensino. Belo Horizonte. 2010.

QUIVY, R. e CAMPENHOUDT, L. V. Manual de investigação em ciências sociais. $3^{\mathrm{a} e d .}$ Trad. J. Minhoto, M. Mendes e M. Carvalho. Lisboa, Portugal: Gradiva, 2003.

RIBEIRO, R. M. L. e MARTINS, I. O potencial das narrativas como recurso para o ensino de ciências: uma análise em livros didáticos de física. Ciência \& Educação. vol. 13, n.3, p. 293309, 2007.

RIGODANZO, L. e UNFER, B. Análise dos livros didáticos do ensino fundamental e médio quanto aos conteúdos de saúde bucal. Educação - UFSM, vol. 30, nº 01, 2005.

ROSEN, G. Da polícia médica à medicina social: ensaios sobre a história da assistência médica. Rio de Janeiro: Graal, 1980. 
ROUQUAYROL, M. Z. e GOLDBAUM, M. Epidemiologia, História Natural e Prevenção de Doenças. In: ROUQUAYROL, M. Z. e ALMEIDA FILHO, N. Epidemiologia \& Saúde. $6^{\text {a }}$ ed. Rio de Janeiro: MEDSI, 2003. p.15-30.

SAMAJA, J. Fundamentos epistemologicos de las ciencias de la salud. 1997. Tese (doutorado). Escola Nacional de Saúde Pública-FIOCRUZ, Rio de Janeiro, 1997.

A reprodução social e a saúde. Casa da Saúde, Salvador, 2000.

SANDRIN, M. F. N., PUORTO, G. e NARDI, R. Serpentes e acidentes ofídicos: um estudo sobre erros conceituais em livros didáticos. Investigações em Ensino de Ciências, vol.10, n³, p. 281-298, 2005.

SANT'ANNA, D. B. Higiene e Higienismo entre o Império e a República. In: DEL PRIORI, M. e AMANTINO, M. História do Corpo no Brasil. São Paulo: Ed Unesp, 2011. p.283-312.

SANTOS, J. O. Filosofia da Educação Médica: interpretação da práxis. Revista Brasileira de Educação Médica. Rio de Janeiro, vol. 10, n. 2, p. 82-86, 1986.

SCHALL, V. T.; BUROCHOVITCH, E.; FÉLX SOUZA, I. C.; VASCONCELOS, M. C. e ROZEMBERG, B. Avaliação dos conhecimentos sobre doenças parasitárias entre os professores e alunos do $1^{\text {o }}$ grau. Ciência e Cultura. Vol. 39 (supl.), p.160-172, 1987a.

SCHAll, V., JURBERG, P., ALMEIDA. E. M., CASZ, C., CAVAlCANTE, F. G. e BAGNO, S. Educação em saúde para alunos de primeiro grau: avaliação de material para ensino e profilaxia da esquistossomose. Revista de Saúde Pública, São Paulo, vol. 21, n.5, p. $387-404,1987 b$.

SCHALL, V. T. e STRUCHINER, M. Educação em saúde: novas perspectivas. Cadernos de Saúde Pública. Rio de Janeiro, v.15, supl. 2, p. S4-S6, 1999.

SCLIAR, M. História do conceito de saúde. PHYSIS: Rev. Saúde Coletiva. Rio de Janeiro, vol. 17, n. 1, p. 29-41, 2007.

SEVALHO, G. Uma abordagem histórica das representações sociais de saúde e doença. Cadernos de Saúde Pública. Rio de Janeiro, vol. 9, n.3, p.349-363, 1993.

SILVA, G. J da e MARTINS, C. M. de C. A confiabilidade e a validação na investigação epistemológica do livro didático de química: um desenho metodológico. Ensaio. Pesquisa em Educação em Ciências, vol. 11, n. 2, p.197-214, 2009.

SILVA, T. T. Documentos de identidade: uma introdução às teorias do currículo. $2^{\mathrm{a}}$ edição. $5^{\mathrm{a}}$ reimpressão. Belo Horizonte: Autêntica, 2003.

SPINK M. J. Trópicos do discurso sobre risco: risco-aventura como metáfora na modernidade tardia. Cad. Saúde Pública. Rio de Janeiro, vol. 17, n.6, p.1277-311, 2001.

STACHTCHENKO, S. \& JENICEK, M. Conceptual differences between prevention and health promotion: research implications for community health programs. Canadian Journal of Public Health. v.81, p.53-59, 1990. 
SUCCI, C. M., WICKBOLD, D. e SUCCI, R.C. M. A vacinação no conteúdo de livros escolares. Rev. Associação Médica Brasileira, vol. 51, n. 2, p.75-79, 2005.

SUSSER, M. e SUSSER, E. Um futuro para a epidemiologia. In: ALMEIDA FILHO, N. et. AL (orgs.). Teoria epidemiológica hoje: fundamentos, interfaces, tendências. Rio de Janeiro: FIOCRUZ/ABRASCO, 1998.

TOLENTINO NETO, L. C. B. O processo de escolha do livro didático de ciências por professores de $1^{\mathbf{a}} \mathbf{a} 4^{\mathrm{a}}$ séries. Dissertação (mestrado em educação). Faculdade de Educação da Universidade de São Paulo (FEUSP). São Paulo. 2003. f.90.

VALADÃO, M. Saúde na Escola: um campo em busca de espaço na agenda intersetorial. Tese (doutorado) Universidade de São Paulo. Faculdade de Saúde Pública. 2004. 154 f.

VASCONCELOS, E. M. Redefinindo as práticas de saúde a partir da educação popular nos serviços de saúde. Interface - Comunicação, Saúde, Educação, Botucatu, vol.5, n.8, p.121$131,2001$.

WESTPHAL, M. Promoção da saúde e prevenção de doenças. In: CAMPOS, G. W. S. et. al. (orgs.). Tratado de Saúde Coletiva. São Paulo: HUCITEC; Rio de Janeiro: Ed. FIOCRUZ, 2006. p. 635-667.

WISLOW, C. E. A. The untilled fields of public health. Science, v. LI, n.1306. 09 de janeiro de $1920 . \quad$ p. 23-32. Disponível em: http://www.sciencemag.org/content/51/1306/23.full.pdf?sid=b0f6c938-b317-46ac-b0245def5824a855. Acesso: 06 fevereiro 2012.

WORLD HEALTH ORGANIZATION (WHO).Preamble to the Constitution of the World Health Organization as adopted by the International Health Conference. New York, 19 June - 22 July 1946 (Official Records of the World Health Organization, n. 2) Disponível em: http://www.who.int/suggestions/faq/en/ . Acesso: 15 março de 2011.

. Health Promotion Glossary. Genebra: WHO/HPR/HEP. 1998. Disponível em: http://www.who.int/hpr/NPH/docs/hp_glossary_en.pdf. Acesso: 16 de abril de 2010.

WORLD HEALTH ORGANIZATION (WHO). Commission on Social Determinants of Health Final Report. Closing Gap in a Generation. 2008. Disponível em: http://whqlibdoc.who.int/publications/2008/9789241563703_eng.pdf. Acesso: 01 abr. 2010.

Disponível

.Milestones in Health Promotion: statements from Global Conferences. 2009.

http://www.who.int/healthpromotion/Milestones_Health_Promotion_05022010.pdf. Acesso: 14 abr. 2010.

.Health Promotion. 2010. Disponível em: http://www.who.int/topics/health_promotion/en/. Acesso: 16 abr 2010.

.Rio Political Declaration of Social Determinants of Health. Rio de Janeiro: WHO; 2011. Disponível em: http://cmdss2011.org/site/2011/10/divulgada-a-declaracao-do-rio/ Acesso: 09 de novembro de 2011. 


\section{ANEXOS}

ANEXO A: As coleções analisadas

\begin{tabular}{|c|c|c|c|c|c|}
\hline Título da Coleção & Editora & Autores & Edição & Ano & $\begin{array}{l}\text { Código } \\
\text { PNLD } \\
2010\end{array}$ \\
\hline $\begin{array}{l}\text { Aprendendo Sempre } \\
\text { - Ciências }\end{array}$ & Ática & $\begin{array}{l}\text { Rogério G. Nigro e Maria } \\
\text { C. C. Campos }\end{array}$ & $1^{\mathrm{a}}$ & 2008 & 15632 \\
\hline $\begin{array}{l}\text { Asas Para Voar - } \\
\text { Ciências }\end{array}$ & Ática & $\begin{array}{l}\text { Amélia P. B. Porto, Lízia } \\
\text { M. P. Ramos e Sheila M. } \\
\text { G. Goulart }\end{array}$ & $1^{\mathrm{a}}$ & 2008 & 15651 \\
\hline $\begin{array}{l}\text { Brasiliana - } \\
\text { Ciências }\end{array}$ & $\begin{array}{l}\text { Companhia } \\
\text { Editora } \\
\text { Nacional }\end{array}$ & $\begin{array}{l}\text { Sônia Bonduki e Carolina } \\
\text { R. Camargo }\end{array}$ & $1^{\mathrm{a}}$ & 2008 & 15674 \\
\hline $\begin{array}{l}\text { Porta Aberta - } \\
\text { Ciências }\end{array}$ & FTD & $\begin{array}{l}\text { Ângela B. A. Gil e Sueli } \\
\text { Fanizzi }\end{array}$ & $\begin{array}{c}\text { Ed. } \\
\text { Renovada }\end{array}$ & 2008 & 15886 \\
\hline $\begin{array}{l}\text { Projeto Conviver - } \\
\text { Ciências Naturais }\end{array}$ & Moderna & $\begin{array}{l}\text { Gilberto Giovannetti e } \\
\text { Geslie Coelho }\end{array}$ & $1^{\mathrm{a}}$ & 2008 & 15907 \\
\hline Projeto Pitanguá & Moderna & $\begin{array}{l}\text { Obra Coletiva (Editor } \\
\text { Responsável José Luiz C. } \\
\text { da Cruz) }\end{array}$ & $2^{\mathrm{a}}$ & 2008 & 15924 \\
\hline Ciências para Você & Positivo & $\begin{array}{l}\text { Márcia S. Fonseca, Maria } \\
\text { H. de Paiva Andrade e } \\
\text { Marta B. Morais }\end{array}$ & $3^{\mathrm{a}}$ & 2007 & 15679 \\
\hline $\begin{array}{l}\text { Descobrindo o } \\
\text { Ambiente - Ciências }\end{array}$ & Saraiva & $\begin{array}{l}\text { Jordelina L. M. Wykrota, } \\
\text { Nyelda R. de Oliveira e } \\
\text { Simone de P.Thomaz }\end{array}$ & $3^{\mathrm{a}}$ & 2008 & 15675 \\
\hline A Escola é Nossa & Scipione & $\begin{array}{l}\text { Karina Alessandra } \\
\text { Pessôa, Leonel Delvani } \\
\text { Favalli e Elisangela } \\
\text { Andrade Ângelo }\end{array}$ & $1^{\mathrm{a}}$ & 2008 & 15611 \\
\hline Caracol - Ciências & Scipione & $\begin{array}{l}\text { Maria do Carmo T. da } \\
\text { Cunha, Maria T. Marsico, } \\
\text { Wilson R. Paulino e } \\
\text { Maria E. M. Antunes }\end{array}$ & $1^{\mathrm{a}}$ & 2008 & 15663 \\
\hline $\begin{array}{l}\text { Ler o Mundo - } \\
\text { Ciências }\end{array}$ & Scipione & $\begin{array}{l}\text { Júlio Röcker Neto e } \\
\text { Luciane Lunedo }\end{array}$ & $1^{\mathrm{a}}$ & 2008 & 15793 \\
\hline
\end{tabular}




\section{ANEXO B: modelo da matriz analítica}

Título da Coleção:

Código PNLD 2010:

Observações do volume
Autores:

Editora:

Edição:

Ano:

\begin{tabular}{|c|c|c|c|c|c|c|}
\hline \multicolumn{7}{|c|}{ Ano } \\
\hline Contexto & Tema/assunto & $\begin{array}{l}\text { Concepçãa de } \\
\text { saúde }\end{array}$ & $\begin{array}{c}\text { Ênfase dos conteúdos } \\
\text { relacionados }\end{array}$ & $\begin{array}{c}\text { Natureza dos } \\
\text { determinantes }\end{array}$ & Enfoque & Natureza das orientações \\
\hline & & $\begin{array}{c}\text { Ausência de } \\
\text { doença } \\
\text { Bem } \\
\text { Direito } \\
\text { Desempenho } \\
\text { Bem estar } \\
\text { (biopsicosocial) }\end{array}$ & $\begin{array}{c}\text { Descrição do agente } \\
\text { etiológico } \\
\text { Descrição dos sinais e } \\
\text { sintomas } \\
\text { Práticas e atitudes de } \\
\text { prevenção } \\
\text { Mudança de } \\
\text { comportamento (estilo de } \\
\text { vida) } \\
\text { Aspectos socioeconômicos } \\
\text { Aspectos ambientais } \\
\text { Aspectos culturais } \\
\text { Saúde como direito } \\
\text { Outros }\end{array}$ & $\begin{array}{c}\text { Biológicos/Fisiológicos } \\
\text { Ambiental } \\
\text { Comportamentais } \\
\text { Cultural } \\
\text { Socioeconômica } \\
\text { Indefinida }\end{array}$ & $\begin{array}{l}\text { Individual } \\
\text { Coletivo }\end{array}$ & $\begin{array}{c}\text { Prevenção de doenças } \\
\text { (agravos ou doenças } \\
\text { específicos) } \\
\text { Estilo de Vida e escolhas } \\
\text { pessoais } \\
\text { Mudança das condições } \\
\text { desfavoráveis }\end{array}$ \\
\hline & \multicolumn{6}{|c|}{$\begin{array}{l}\text { Observações } \\
\text { Excertos }\end{array}$} \\
\hline
\end{tabular}

